\title{
AS FLUTUAÇÕES DE NÍVEL DO MAR DURANTE O QUATERNÁRIO SUPERIOR E A EVOLUÇÃO GEOLÓGICA DE "DELTAS" BRASILEIROS
}

\author{
LMartin \\ K. Suguio \\ J.M. Flexor
}

\section{RESUMO}

Ao longo do litoral brasileiro existem extensas áreas de progradação quaternária, a maioria das quais vinculada a importantes desembocaduras fluviais, enquanto que outras não apresentam qualquer ligação com desembocaduras fluvials, atuais ou pretéritas. Todos os casos, até aqui estudados, podem ser explicados pelo modelo de evolução paleogeográfica concebido pelos autores, válldo para o trecho Macaé (RJ) a Maceló (AL). Dois ou mais dos estádios do modelo completo podem ser omitidos na explicação da história evolutiva de algumas dessas planícies.

As planícies costeiras dos rios Doce (ES) e Parafba do Sul (RJ) caracterizam-se pela presença de expressivos deltas intralagunares, que foram construidos no interior de extensas paleolagunas. As planícies costeiras dos rios Jequitinhonha (BA) e São Francisco (SE/AL), ambas de menor expressão do que as anteriores, não apresentam deltas intralagunares porque nunca chegaram a desenvolver lagunas de maior porte durante a sua evolução geológica. Por outro lado, a foz do Rio Parnafba (PI/MA) pode ser considerada como de domínio essencialmente é́lico e a planície de Caravelas (BA) não possui qualquer relação com desembocadura fluvial.

Nessas planicles, que foram freqüentemente descritas como essencialmente holocênicas, foram também encontrados sedimentos pleistocênicos ao lado dos holocênicos. Além disso, a variação de nivel relativo do mar durante o Quaternário superior, quase sempre completamente ignorada nos estudos de deltas quaternários de vários paises, desempenhou um papel essencial na formação dessas planícies.

Finalmente, considerando-se a definição de delta sensu strictu, mesmo as planicles costeiras situadas nas principais desembocaduras fluviais não podem ser consideradas como verdadeiros deltas, já que os seus sedimentos foram só parcialmente supridos pelo rio, sendo em grande parte resultantes de retrabalhamento de sedimentos reliquiares da plataforma continental.

A compreensão da evolução geológica das planícies costeiras, durante os últimos milhares de anos, fornece valiosas informações sobre as mudanças paleoambientais em geral $\theta$, também, pode explicar as tendências da dinâmica atual. Deste modo, pode ajudar a solucionar vários problemas, como os relacionados aos fenômenos de erosão e sedimentação acelerados, com ou sem influência antrópica, em gerenciamento costeiro. 


\section{ABSTRACT}

Along the Brazilian coast, there are several extensive progradation areas, frequently related to important river mouths, while others don't have any relationship with present or past river mouths. All the studied cases, up to that time, can be explained through the paleogeographic evolutionary model concelved by the authors, valid for the sector from Macae (State of Rio de Janeiro) to Maceio (State of Alagoas). Two or more stades from the most complete model can be omitted to explain the evolutionary history of some of these coastal plains.

The coastal plains associated to the Doce (State of Espirito Santo) and Parafba do Sul (State of Rio de Janeiro) rivers are the most important, being characterized by expressive lagoonal deltas constructed within large paleolagoons. The coastal plains of the Jequitinhonha (State of Bahla) and São Francisco (States of Sergipe/Alagoas) rivers don't exhibit intralagoonal deltas, because they never developed extensive paleolagoons during their geological evolution. On the other hand, the Parafba river mouth (State of Piaul/Maranhão) could be assumed as an essentially wind-dominated coastal plain, and the Caravelas (State of Bahia) coastal plain doesn't have relationship with any river mouth.

These coastal plains have been before considered as essentially Holocene in age, but there are Pleistocene and Holocene deposits. Moreover, the Quaternary relative sea-level changes, completely ignored in some countries to explain this type of coastal plains, played an essential role in the Brazilian coast.

Finally, considering the sensu strictu definition of delta, even the coastal plains associated with river mouths could not be assumed as true deltas, because their sediments were only partially supplied by the rivers.

The understanding of geological evolution of these coastal plains, during the last millenia, supply us with useful information about the paleoenvironmental changes, as well as, with possible explanations about the present dynamics in terms of erosion and sedimentation. Therefore, could be useful to solve many problems, like that related with accelerated erosion and sedimentation, with or without anthropic influence, in coastal management. 


\section{INTRODUÇÃO}

Associadas às desembocaduras dos principais rios que despejam suas águas no Oceano Atlântico, ao longo da costa brasileira, existem zonas de progradação que BACOCCOU (1971), tomando por base a definição de SCOTT \& FISHER (1969), interpretou como deltas. Alguns, como o do Rio Amazonas, seriam do tipo altamente destrutivo dominado por marés, enquanto outros, como os dos rios Parnaíba, Jaguaribe, São Francisco, Jequitinhonha, Doce e Paralba do Sul (Fig. 1), seriam do tipo altamente destrutlvo dominado por ondas. Além disso, BACOCCOU (op.cit.) atribuiu a todos esses deltas uma idade holocênica, ao mesmo tempo em que propôs um esquema evolutivo segundo o qual essas planícies costeiras teriam se formado a partir do máximo da transgressão Flandriana (última grande transgressão quaternária), passando em alguns casos por uma fase estuarina intermediária, até formarem deltas típicos cuja construção resultaria em avanço generalizado da linha de costa.

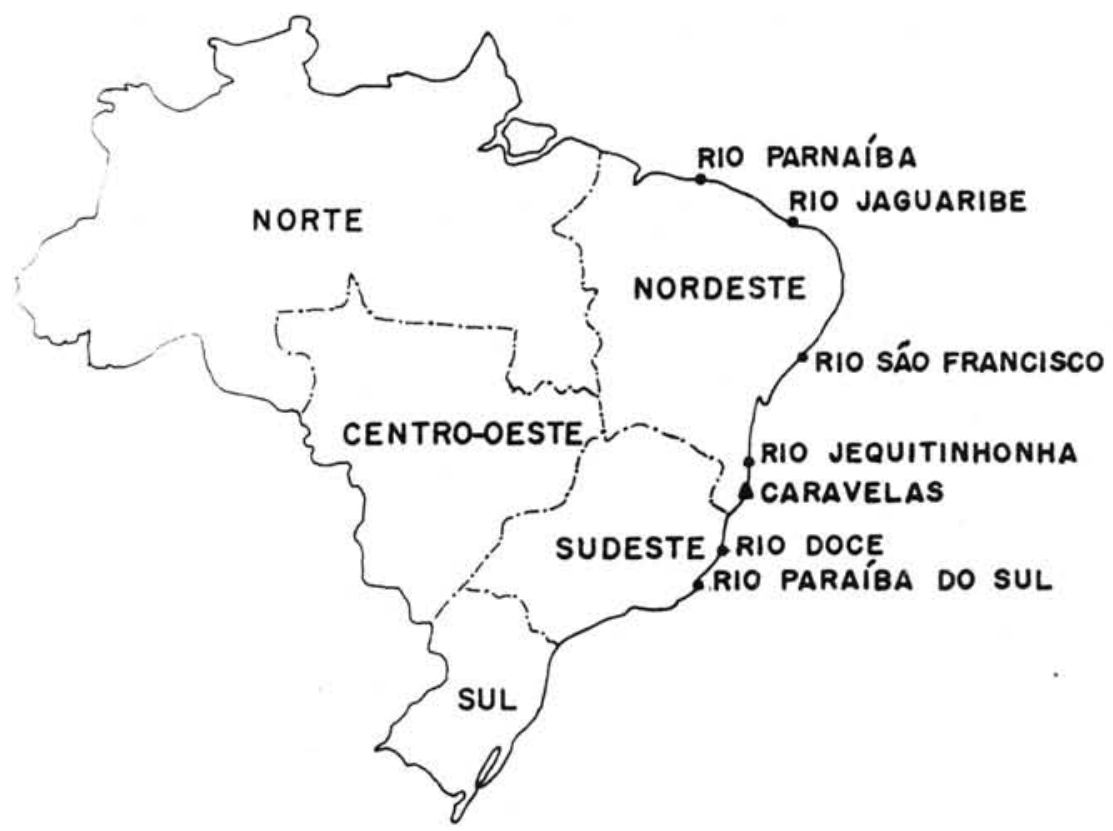

Figura 1 - Posiçöes geográficas dos "deltas holocênicos" brasileiros (BACOCCOLI, 1971) e a localização da planície costeira de Caravelas (BA).

Entretanto, existem também ao longo do litoral brasileiro vastas zonas em progradação sem nenhuma ligação com qualquer desembocadura fluvial atual ou pretérita. Uma dessas áreas mais dignas de nota situa-se em Caravelas (BA) onde, excetuando-se as fácies fluviais, ocorrem todos os outros tipos de depósitos sedimentares existentes nos deltas holocênicos brasileiros 
(Fig. 1). Por esta razão, BACOCCOU (op.cit.) chegou a sugerir que a acumulação de sedimentos poderia representar um possivel delta do Rio Mucuri, inexpressivo curso fluvial localizado na porçäo sul da área. Desta maneira, a região de Caravelas representaria um caso típico de delta destrutivo dominado por ondas, construldo sem a presença de um riol O fato de ter sido possivel a formaçăo de zona de progradaçăo sem aporte sedimentar fluvial chamou imedlatamente a atençăo dos autores deste trabalho. É evidente que, neste caso, seria necessário procurar alhures a fonte de sedimentos arenosos que serviram para a progradação.

Um exame dos parâmetros considerados por diferentes autores que têm estudado os deltas mostra que nenhum deles levou em conta o papel das flutuaçöes de nivel relattvo do mar. Essas variaçöes podem resultar da mudança real de nivel do mar (eustasia) e das modificações de nivel dos continentes (tectonismo e isostasia). As variações de volume de água dos oceanos (glácioeustasia) $\theta$ as modificaçōes de volume das bacias oceânicas (tectono-oustasia) fazem sentir os seus efeitos em escala mundial. Por outro lado, as modificações da superfície do geóide (geóido-eustasia) e as modificações de nivel da crosta terrestre influem em escalas local ou regional. Então, é evidente que as varlações de nivel relativo do mar não foram forçosamente as mesmas em todos os pontos da Terra. Pesquisas realizadas na porção central (nordeste, leste $\theta$ sudeste) do litoral brasileiro mostraram que esta passou nos últimos 5.000 anos por uma fase de emersão da ordem de 4 a $5 \mathrm{~m}$. Porém, esta não é a situação, por exemplo, na costa atlântica e do Golfo do México dos Estados Unidos, que conheceram uma evolução muito diferente. Nessas áreas, o nivel relativo do mar situavase cerca de $5 \mathrm{~m}$ abaixo do atual e elevou-se progressivamente até chegar a sua posição de hoje. Portanto, pode-se dizer que nos últimos 5.000 anos, o litoral brasileiro caracterizou-se por um processo de emersão, enquanto que o litoral oriental dos Estados Unidos esteve em contínua submersão. Desta maneira, evidentemente, a dinâmica litorânea não fol a mesma nos dois casos, pois um abaixamento de nivel do mar promove importante aporte de arela da antepraia para a pós-praia. Essas arelas podem ser transportadas, ao longo da costa, pelas correntes de deriva litorânea até serem bloqueadas por um obstáculo que assim proporcionará a progradação da linha de costa. Naturalmente, os modelos de sedimentação deltaica idealizados a partir de exemplos de costa em submersão não podem ser aplicados diretamente no Brasil. Os estudos anteriores realizados nas planicies costeiras do Rio Doce (ES) por BANDEIRA JÚNIOR et al. (1975) e do Rio Parafba do Sul (RJ) por LAMEGO (1955) e ARAÚJO et al. (1975), por falta de dados na época, não consideraram o papel desempenhado pelo abaixamento de nivel relativo do mar.

Assim, resolvemos empreender um estudo pormenorizado das planícies costeiras situadas nas desembocaduras dos rios Parafba do Sul, Doce, Jequitinhonha, São Francisco, Jaguaribe e Parnalba. Este estudo baseou-se na fotointerpretação, trabalhos de campo e numerosas dataçöes 
ao radiocarbono, que permitiram mapear sistematicamente e reconstruir com precisão as etapas sucessivas da evolução geológica durante o Quaternário.

Se, de um lado, BACOCCOU (op.cit.) reconhecia que a sua experiência de campo limitava-se a breves excursões aos deltas dos rios Parafba do Sul, Doce, Jequitinhonha $\theta$ São Francisco, grande fol a nossa surpresa ao confrontarmos os mapas obtidos por nós com os publicados por aquele autor. Mesmo reconhecendo-se a natureza bastante esquemática dos mapas daquele autor, pode-se ainda constatar grandes discrepâncias. Assim, por exemplo, os limites das planícies costeiras dos rios Paraf́ba do Sul, São Francisco, Jaguaribe e Parnafba são muito imprecisos. Segundo aquele autor, a planície costeira do Rio São Francisco ocuparia uma superfície de $2.000 \mathrm{~km}^{2}$ enquanto que, na realidade, ela não passa de $750 \mathrm{~km}^{2}$. No caso da planícle do Rio Jaguaribe, BACOCCOL atribuiu uma superfície de cerca de $300 \mathrm{~km}^{2}$ quando, na verdade, pode-se verificar no terreno que não ocorre propriamente uma planície costeira quaternária mas somente uma área de dunas móveis sobre sedimentos da Formação Barreiras. Além disso, foi possivel constatar que parte dessas planícies apresenta também sedimentos de idade pleistocênica e não somente holocênica, conforme admitia aquele autor. Prosseguindo as nossas pesquisas fol constatado que o mapa da planície costeira do Rio São Francisco, utilizado por COLEMAN \& WRIGHT (1975) como modelo de deltas altamente destrutivos dominados por ondas, era grosseiramente falso.

Desta maneira, sem considerar os modelos deltaicos previamente estabelecidos, decidimos reconstruir a evolução dessas planícies costeiras durante o Quaternário com base em dados e experiências prévias em outras partes do litoral brasileiro. Em vista desta reconstrução, podese mesmo questionar se o termo delta seria o mais apropriado para referir-se às zonas de progradação situadas nas desembocaduras dos principais rios brasileiros que despejam suas águas no Oceano Atlântico. 


\section{FLUTUAÇÕES DE NÍVEL RELATIVO DO MAR NO QUATERNÁRIO AO LONGO DO LITORAL BRASILEIRO}

\subsection{Complexidade dos fatores que regem as variações de nível do mar (Fig. 2).}

As flutuações de nível relativo do mar resultam das variações reais de nivel marinho (eustasia) e das mudanças de nivel dos continentes (tectonismo e isostasia). Portanto, é evidente que quando se efetuam reconstruções de antigos níveis marinhos, estes se referem a posições relativas e não absolutas, pois estas são multo difíceis de serem reconstruídas.

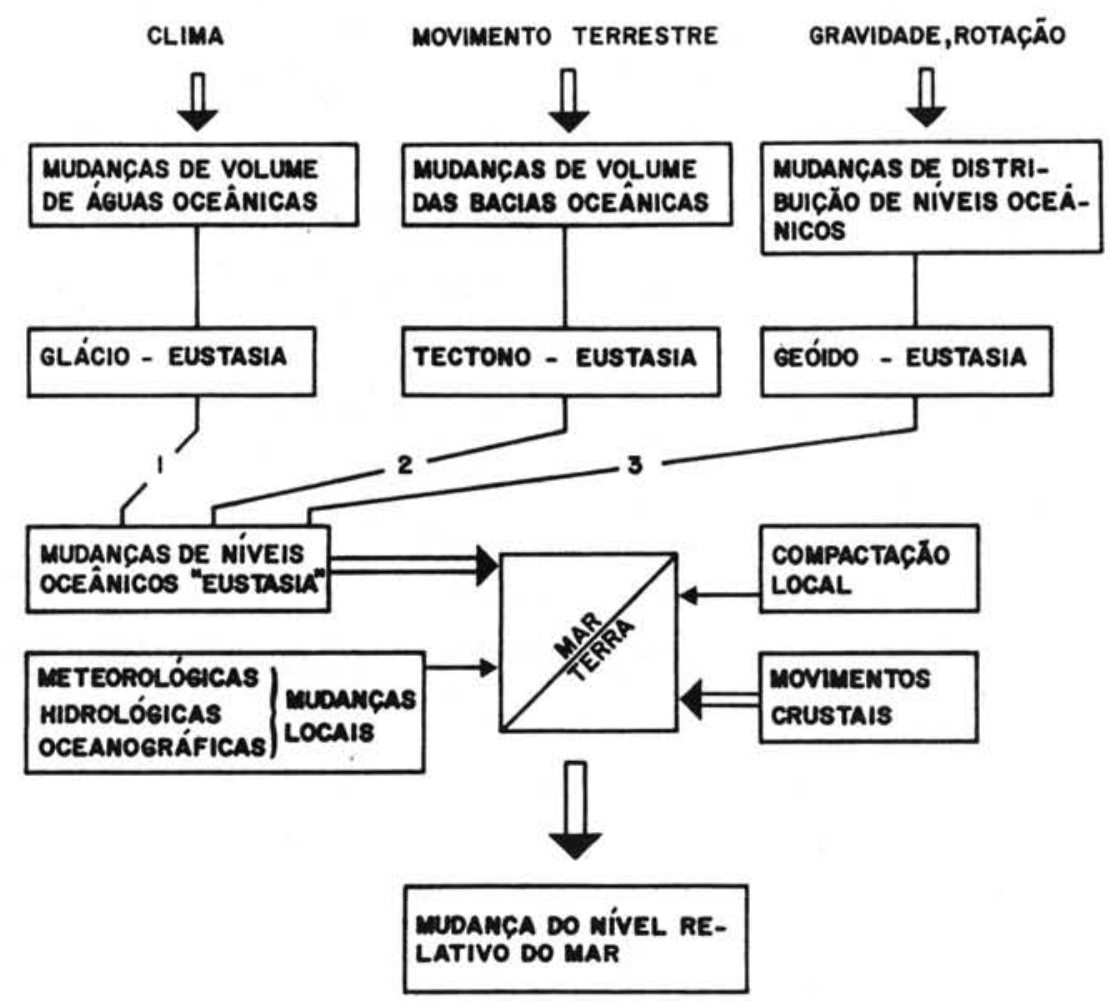

Figura 2 - Complexa interação dos mecanismos que atuam em diferentes escalas (global, regional e local), determinando as flutuaçōes de nível relativo do mar durante o Quaternário (MARTIN et al., 1986c).

Os niveis dos continentes são controlados pelos seguintes fatores:

a) Movimentos tectônicos, tanto horizontais quanto verticais, que afetam a crosta terrestre segundo mecanismo cuja duração pode ser desde quase instantânea (movimentos sísmicos) até de período muito longo. 
b) Movimentos isostáticos, ligados às variações de carga em função da formação ou desaparecimento de calotas glaciais, erosão dos continentes, deposição em bacias sedimentares, transgressões e regressões sobre as plataformas continentais (hidroisostasia).

c) Deformaçăo do geb́lde continental que constitui a nossa superficie de referêncla atual.

Os niveis oceânicos, por seu lado, são também controlados por diversos fatores, tais como:

a) Modificaçőes no volume total das bacias oceânicas em conseqüência da tectônica de placas (tectono-өustasia).

b) Variações nos volumes das águas dos oceanos em função das glaciações e deglaciações (glácio-eustasia).

c) Deformações da superfície dos oceanos (geóido-өustasia).

A altura da superfície do mar apresenta uma componente oceânica e outra geofísica. Os efeitos oceanográficos que podem afetar a altura do mar são essencialmente as marés, as grandes correntes $\theta$ os turbilhonamentos associados às variações de declividades devidas ao vento, à pressão e à temperatura de água ou à salinidade. A soma desses efeitos não é superior a 1$2 \mathrm{~m}$, sendo então pequena em relação às enormes concavidades e intumescências da superfície dos oceanos causadas pelas diferenças de densidade do interior da Terra. Esta componente geofisica corresponde ao geóide e se confunde com o nivel médio do mar. A partir de 1975, têm sido executadas medidas altimétricas geodésicas através de satélites artificiais, como GEOS-3 e SEASAT, que têm permitido medir com grande precisão a posição da superfície do mar. Deste modo, é possivel mostrar a existência de ondulações de grande comprimento de onda e com várias dezenas de metros de amplitude (até $100 \mathrm{~m}$ ao sul da Índia). Argumentos baseados na falta de correlação entre essas ondulações e a topografia de fundo, de um lado, sua amplitude e comprimento de onda, de outro lado, fazem com que elas sejam geralmente atribuidas a contrastes de densidade no manto superior ou mesmo na interface núcleo/manto. Quando essas ondulações possuem comprimentos de onda mais curtos, o geóide marinho apresenta um espectro muito variado de anomalias.

A superfície do geóide corresponde a uma superfície eqülpotencial do campo gravitacional terrestre, sendo controlada pelas forças de rotação e de gravidade que afetam o globo terrestre. Estas forças e, conseqüentemente a forma do geóide, variam, não somente em função da composição do núcleo $\theta$ do manto $\Theta$ das relações entre a astenosfera $\theta$ a litosfera, mas também em função de vários fenômenos orbitais e de suas interações (MÖRNER, 1980). As modificações da superfície do gé́ide parecem processar-se muito rapidamente pois, segundo MÖRNER (1984), as taxas podem chegar a $10 \mathrm{~mm} /$ ano com gradientes de vários metros por quilômetro. Uma mudança de 
1 miligal na força gravitacional deformaria a superficie oceânica de $3,3 \mathrm{~m}$ e a superfícle da crosta terrestre de $1,7 \mathrm{~m}$.

O nivel do mar em um determinado ponto do litoral é, portanto, a resultante momentânea de interações complexas entre a superfície do oceano e do continente. As modificações de volume das bacias oceânicas (tectono-eustasia) e as variações de volume dos oceanos (glácioeustasia) fazem sentir os seus efeitos em escala mundial. Por outro lado, as modificações de nivel dos continentes e da superfície do geóide atuam em escalas local ou regional.

Então, é normal que sejam verificadas discrepânclas entre as reconstruções de posições de antigos níveis marinhos da mesma época em diversos pontos do globo terrestre, fato que é praticamente perceptivel nos últimos 7.000 anos. De fato, antes de 7.000 anos A.P. (Antes do Presente) a velocidade de subida glácio-eustática era tão rápida que poderia mascarar as componentes derivadas de fatores locais ou regionais.

\subsection{Evidências de antigos niveis marinhos quaternários}

Tem sido observado que as flutuações de nivel relativo do mar durante o Quaternário foram muito importantes na evolução das planícies costeiras do Brasil. Essas evidências vem sendo mencionadas há longo tempo (HARTT, 1870; BRANNER, 1904; FREITAS, 1951 e BIGARELLA, 1965). No início, essas evidências foram estudadas exclusivamente sob enfoque geomorfológico, tendo sido atribuídas ao Terciário, mas atualmente são relacionadas ao Quaternário. Até a década de 60 , pesquisas sobre flutuações de nivel marinho durante o Quaternário eram muito escassas no Brasil (SUGUIO, 1977). Uma das pesquisas, algo sistemática, incluindo idades ao radiocarbono, foi realizada por VAN ANDEL \& LABOREL (1964).

Após 1974, as flutuações de nivel marinho durante o Quaternário, principalmente durante os últimos 7.000 anos, têm sido estudadas por vários grupos de pesquisadores. Esses grupos concluíram os estudos das formações quaternárias do Estado de São Paulo e sul do Río de Janeiro (MARTIN \& SUGUIO, 1975, 1976a, 1976b, 1976c, 1978a, 1978b; SUGUIO \& MARTIN, 1976a, 1976b, 1978a, 1978b, 1978c, 1982a, 1982b; MARTIN et al., 1979b, 1980b; SUGUIO et al., 1980): dos estados da Bahia, Sergipe e Alagoas (BITTENCOURT et al., 1979a, 1979b, 1982a, 1982b, 1983a, 1983b; MARTIN et al., 1978, 1979a, 1980a, 1980b, 1980c, 1981a, 1981b, 1982, 1983, 1984a; VILAS-BOAS et al., 1979, 1985; DOMINGUEZ, 1982; DOMINGUEZ et al., 1981a, 1981b, 1983); da parte norte do litoral do Espírito Santo (SUGUIO et al., 1982; MARTIN et al., 1984b); do norte do Estado do Rio de Janeiro (MARTIN et al., 1984c, 1984e, 1985b; SUGUIO et al., 1985b); dos estados do Paraná e Santa Catarina (MARTIN \& SUGUIO, 1986; MARTIN et al., 1986; SUGUIO et al., 1986; MARTIN et al., 1988) e do Estado do Rio Grande do Sul (TOMAZELL et al., 1982; VILWOCK, 1984; VILLWOCK et al., 1986). 


\subsubsection{Evidências sedimentológicas}

Depósitos arenosos quaternários de origem marinha, situados acima do nivel marinho atual, representam evidências inquestionáveis de niveis marinhos pretéritos acima do atual. Mapeamentos geológicos sistemáticos e dataçőes por radiocarbono desses depósitos têm permitido distinguir várias gerações de terraços arenosos formados subseqüentemente aos niveis máximos relacionados a diferentes episódios transgressivos no Quaternário.

\subsubsection{Evidências biológicas}

As evidências biológicas são representadas por incrustações de vermetídeos (gastrópodos), ostras e corais bem como por buracos de ouriços, situados acima do nivel atual de vida desses animais, indicando niveis marinhos acima do atual (LABOREL, 1969, 1979). Além disso, muitos terraços marinhos pleistocênicos e holocênicos apresentam numerosas tocas fossilizadas (em forma de tubos) de Callichirus, situadas acima da atual zona de vida deste crustáceo (SUGUIO \& MARTIN, 1976b; SUGUIO et al., 1984; RODRIGUES et al., 1984).

\subsubsection{Evidências pré-históricas}

Numerosos sambaquis, construídos pelos antigos índios que habitavam no litoral, são encontrados nas planícies costeiras do sudeste e sul do Brasil. As posições geográficas desses sambaquis, freqüentemente situados bem no interior (até mais de $30 \mathrm{~km}$ da atual linha de costa), só podem ser explicadas por extensão lagunar claramente maior do que a atual e, conseqüentemente, por um nivel marinho mais alto do que o de hoje (MARTIN et al., 1984d, 1986d, 1986e).

\subsection{Niveis marinhos pretéritos mais altos do que o atual (Fig. 3)}

\subsubsection{Niveis marinhos altos anteriores a 123.000 anos A.P.}

Somente na planície costeira do Rio Grande do Sul foram encontrados dois níveis marinhos provavelmente mais antigos do que 123.000 anos A.P. (Sangamoniano = Riss/Würm). VILLWOCK et al. (1986) atribuíram tentativamente aos dois niveis idades do Pleistoceno médio e do Pleistoceno inferior, designando-os, respectivamente por Barreira II e I. Deste modo, poderiam ser referidos aos estádios interglaciais Mindel/Riss (=Yarmouthiano) e Günz/Mindel (=Aftoniano), respectivamente. Em localidades esparsas das planícies costeiras de Santa Catarina, Paraná e provavelmente São Paulo (atrás do Morro de Icapara, Iguape), são encontrados terraços arenosos ou de cascalhos, de origem possivelmente marinha, com altitudes de até pouco mais de $13 \mathrm{~m}$, eventualmente correlacionáveis à Barreira II do Rio Grande do Sul (MARTIN et al., 1988). Nenhuma 
evidência de nivel marinho pretérito correlacionável à Barreira I foi encontrada fora do Rio Grande do Sul.

\subsubsection{Nivel marinho alto de 123.000 anos A.P.}

Naquela época, o nivel relativo do mar deve ter chegado a $8 \pm 2 \mathrm{~m}$ acima do atual. Esta fase de nivel marinho diferente ao de hoje é conhecida como Transgressão Cananéla no litoral paulista (SUGUIO \& MARTIN, 1978a) e como Penúltima Transgressão nas planícies costeiras dos estados da Bahia, Sergipe e Alagoas (BITTENCOURT et al., 1979a). A idade desta transgressão foi estabelecida graças a cinco datações realizadas em amostras de corais, coletadas na base do terraço marinho no litoral da Bahia, pelo método lo/U (MARTIN et al., 1982). Infelizmente, nos terraços correlacionáveis à Formação Cananéia nas costas sudeste e sul do Brasil, embora muito bem preservados em certas áreas, como em Cananéia (SP) e Paranaguá (PR), não foram encontrados materiais datáveis para obtenção de idades absolutas. Porém, troncos de madeira coletados das argilas basais desta formação têm indicado idades além do alcance normal do método do radiocarbono, isto é, cerca de 30.000 anos A.P. Além disso, segundo MASSAD (1985), comportamentos geotécnicos dos sedimentos argilosos da base da Formação Cananéla e da Formação Santos (holocênica) são bem distintos, sendo no primeiro caso sobre-adensados e no segundo muito moles a moles.

Os testemunhos deste nivel marinho alto são formados por terraços de construção marinha essencialmente arenosos encontrados, pelo menos, desde o Estado do Paraíba até o Rio Grande do Sul. A partir de estruturas sedimentares hidrodinâmicas e de galerias fósseis de Callichirus é possível reconstruir as posições de nivel relativo do mar mas, em conseqüência da escassez de datações absolutas, não é possível construir curvas de variações de nível relativo do mar em torno de 123.000 anos A.P. e comparar as altitudes das reconstruções da mesma faixa de idade em diversos pontos do litoral brasileiro.

\subsubsection{Nível marinho alto holocênico}

O nivel marinho alto mais recente é bem conhecido em função de numerosas reconstruções de antigas posições de nivel relativo do mar no tempo e no espaço, que puderam ser realizadas a partir de mais de 700 datações por radiocarbono (SUGUIO et al., 1985a).

Além disso, as posições de certos sambaquis, confrontadas com idades ao radiocarbono e valores de $\delta^{13} \mathrm{C}_{(\mathrm{PDB})}$ dos carbonatos das conchas constituintes, têm fornecido informações complementares interessantes sobre as oscilações de nivel relativo do mar durante cerca de 5.500 anos A.P. (FLEXOR et al., 1979). 
A partir de todas essas informações, tem sido possível construir curvas ou esboços de curvas de variações de nível relativo do mar para diversos setores do litoral brasileiro. A fim de obter curvas homogêneas, foram utilizados dados provenientes de setores relativamente curtos do litoral com caracteristicas geológicas uniformes.

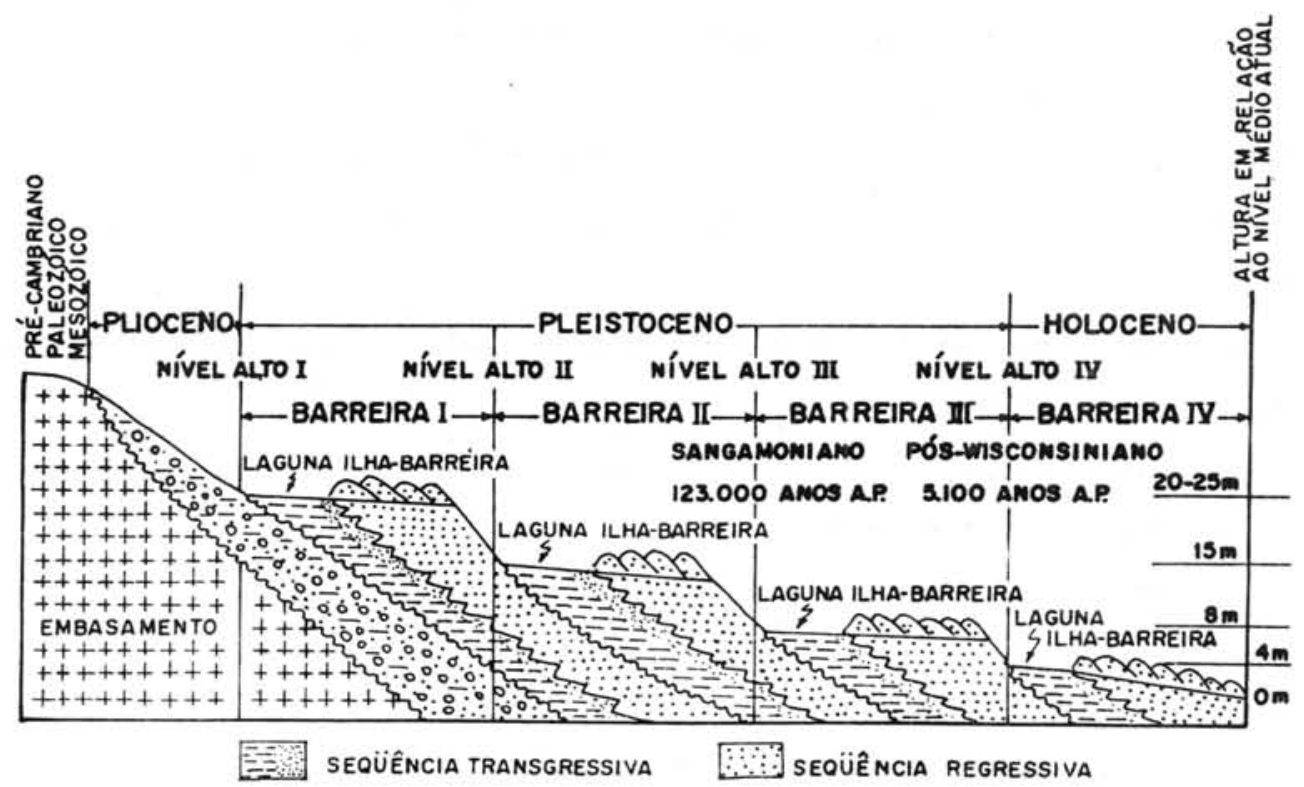

Figura 3 - Sistemas de ilhas-barreiras/lagunas (I a IV), formados durante quatro períodos de níveis relativos do mar mais altos do que o atual, ao longo do litoral do Rio Grande do Sul (Modificado de VILLWOCK et al., 1986).

\subsection{Curvas de variação de nível relativo do mar durante os últimos 7.000 anos em vários} setores do litoral brasileiro

Quando se pretende construir uma curva homogênea de variações de nivel relativo do mar é evidente que devem ser utilizadas somente informações provenientes de um setor do litoral onde os fenômenos locais sejam semelhantes. Freqüentemente, somos obrigados a escolher entre as duas alternativas seguintes: (a) construir uma curva baseada em numerosas informações cobrindo todo o intervalo de tempo considerado, porém isto pode implicar na utilizaçăo de um setor relativamente grande do litoral, correndo o risco de que os fatores locais não sejam tão semelhantes ao longo de todo o setor, ou (b) considerar um setor limitado, onde se tem certeza da semelhança de comportamento, porém neste caso as informações podem ser numericamente insuficientes para permitir a delineação de uma curva precisa e completa. 
No decorrer da última década, fol possivel construir curvas ou trechos de curvas para diversos setores mais ou menos homogêneos do litoral brasileiro entre o norte do Estado de Alagoas e o sul do Estado de Santa Catarina. (Fig. 4)

\subsubsection{Setor situado ao norte de Salvador (BA)}

Neste setor de cerca de $50 \mathrm{~km}$ de extensão, foram obtidas cerca de 60 reconstruções de antigas posições de nivel relativo do mar, que cobrem mais ou menos regularmente os últimos 7.000 anos (Fig. 4a). A partir desses dados foi obtida uma curva bastante precisa mostrando que:

a) O "zero atual" (nivel médio do mar de hoje) fol ultrapassado pela primelra vez no Holoceno há cerca de 7.100 anos A.P.;

b) Cerca de $\mathbf{5 . 1 0 0}$ anos A.P., o nivel relativo do mar passou por primeiro pico positivo situado 4,8 $\pm 0,5 \mathrm{~m}$ acima do atual;

c) Após este pico, ocorreu uma ráplda regressão até cerca de 4.900 anos A.P., mais lenta até 4.200 anos A.P. e novamente mais rápida até 3.900 anos A.P. Nesta época, o nivel relativo do mar devia situar-se pouco abaixo do atual;

d) Entre 3.900 e 3.600 anos A.P., nivel relativo do mar elevou-se multo rapidamente $\Theta$ há cerca de 3.600 anos A.P. este passou por segundo pico positivo situado $3,5 \pm 0,5 \mathrm{~m}$ acima do atual.

e) Entre 3.600 e 3.000 anos A.P., o nivel relativo do mar caiu lentamente. A partir de 3.000 anos A.P. o abaixamento foi muito rápido até 2.800 anos A.P. Nesta época, o nivel relativo do mar devia situar-se pouco abaixo do atual.

f) Entre 2.700 e 2.500 anos A.P., o nivel relativo do mar elevou-se multo rapidamente e há cerca de 2.500 anos A.P. este passou por um terceiro pico positivo situado 2,5 $\pm 0,5 \mathrm{~m}$ acima do atual, $\Theta$

g) Após 2.500 anos A.P., o nivel relativo do mar abaixou regularmente até a posição atual.

Esta curva, muito bem delineada, pode servir de referência para outros setores onde as informaçöes tenham sido insuficientes para se construir uma curva completa. Nesses setores, pode-se referir à curva de Salvador e verificar se as reconstruções realizadas estão ou não deslocadas em relação àquela curva. Desta maneira, pode-se ter uma idéla da evolução do nivel relativo do mar para o setor considerado durante os últimos 7.000 anos.

\subsubsection{Setor situado entre ltacaré e llhéus (BA)}

Neste setor de cerca de $60 \mathrm{Km}$ de comprimento, o número de reconstruções de 


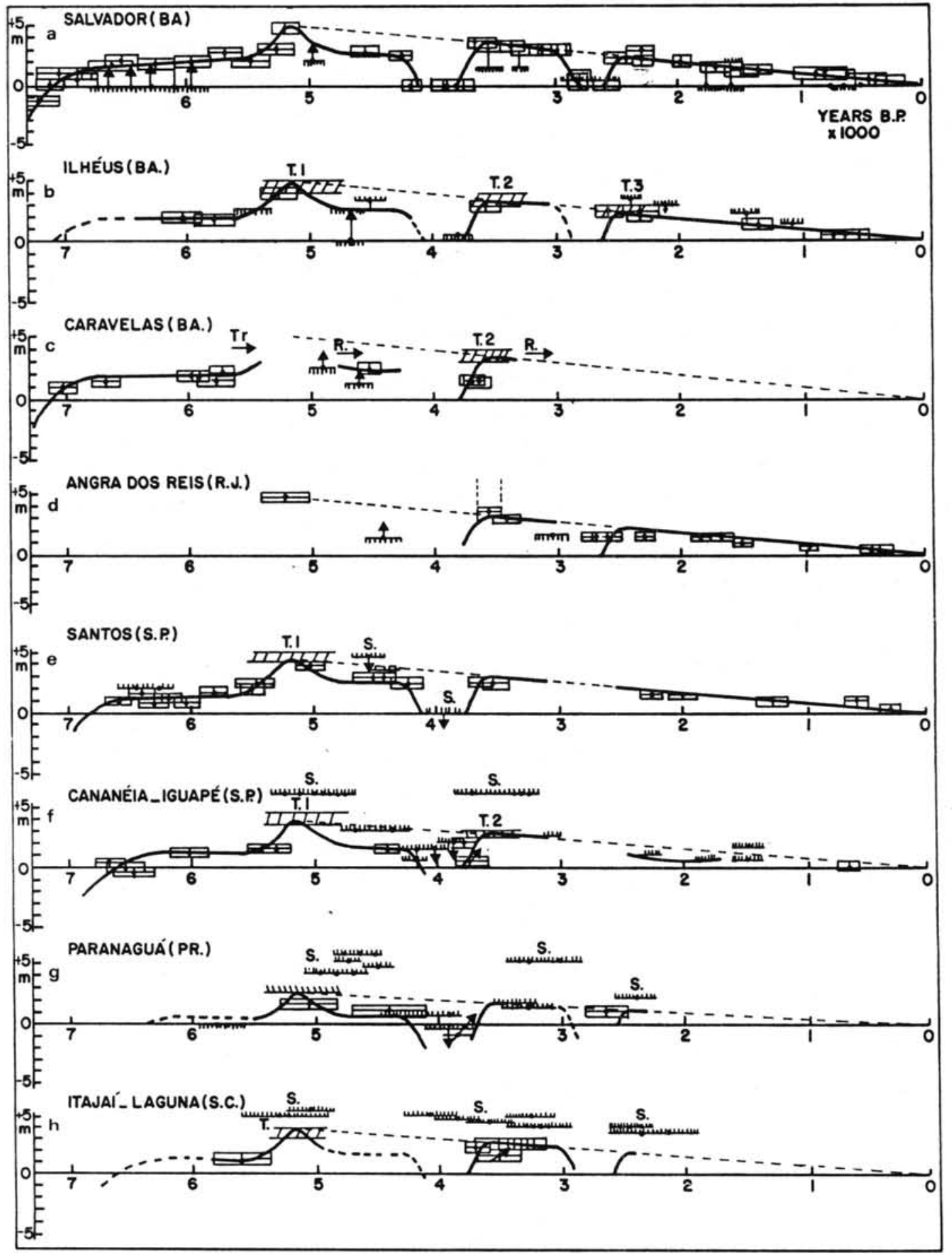

Figura 4 - Curvas de flutuações de nível relativo do mar de 7.000 anos A.P. até hoje, construídas através de indicadores diversos (geológicos, biológicos e pré-históricos) para vários setores do litoral brasileiro (SUGUIO et al., 1985a). 
antigas posiçőes de nivel relativo do mar foi insuficiente para se obter uma curva completa (Fig. 4b). Entretanto, as informações obtidas não apresentam desvios notáveis em relação à curva de Salvador. Foi possível evidenciar a ocorrência de três terraços arenosos situados respectivamente entre 5 a 4,4 a 3 e 3 a 2 m acima do atual, evidenciando três picos positivos de nivel do mar durante o Holoceno. Logicamente, esses três terraços devem corresponder aos três picos positivos encontrados no setor de Salvador, situados respectivamente a 5,0 $\pm 0,5 \mathrm{~m}, 3,5 \pm 0,5 \mathrm{~m}$ e 2,5 $\pm 0,5 \mathrm{~m}$ acima do nivel atual.

\subsubsection{Setor situado entre Caravelas e Nova Viçosa (BA)}

Este setor estende-se por cerca de $30 \mathrm{~km}$, onde foram realizadas 11 reconstruções. Entretanto, 7 dessas informações situam-se entre 7.000 e 5.700 anos A.P., permitindo estabelecer com precisão este trecho da curva (Flg. 4C). Desta maneira, parece que o "zero atual" fol ultrapassado pela primeira vez há cerca de 7.100 anos A:P. Outra evidência sugere que em torno de 4.500 anos A.P., o nivel relativo do mar situava-se 2,5 $\pm 0,5 \mathrm{~m}$ acima do atual. Finalmente, temos também dados que mostram que entre 3.700 e 3.600 anos A.P. o nivel relativo do mar estava em elevação e que apresentou um pico positivo situado 3 a $4 \mathrm{~m}$ acima do atual. Todos esses dados estão perfeitamente de acordo com a curva de Salvador.

\subsubsection{Setor situado entre Angra dos Reis e Parati (RJ)}

Este setor apresenta cerca de $60 \mathrm{Km}$ de extensão e fol possivel realizar 17 reconstruções que não permitiram delinear uma curva completa (Fig. 4d). Entretanto, o trecho da curva entre a época atual e 2.500 anos A.P. ficou bastante bem definido. Foi também possivel reconhecer a existência de dois picos positivos, um levemente superior a 3m entre 3.600 e 3.450 anos A.P. e outro cerca de $4,8 \mathrm{~m}$ aproximadamente há 5.200 anos A.P.

\subsubsection{Setor situado entre Bertioga e Praia Grande (Região de Santos, SP)}

Neste setor, de $60 \mathrm{~km}$ de comprimento, foram obtidas aproximadamente 30 reconstruções que permitiram estabelecer uma curva bastante completa (Flg. 4e). Especialmente o trecho entre 6.600 e 5.500 anos A.P. foi delineado com precisão em função de 10 reconstruções. É também interessante constatar que o "zero atual" foi ultrapassado há 6.800 anos A.P. e, portanto, mais tarde do que no setor de Salvador. Finalmente, os picos positivos de 5.100 e 3.600 anos A.P. ficaram situados respectivamente cerca de 4,5 e $3 \mathrm{~m}$ acima do nível atual.

\subsubsection{Setor situado entre Iguape e Cananéla (SP)}

Este trecho estende-se por cerca de $100 \mathrm{~km}$ mas somente 10 evidências de níveis 
marinhos pretéritos do Holoceno foram datadas, das quais 7 estão situadas entre 6.650 e 5.300 anos A.P., o que permitiu delinear com boa precisão esta porção da curva (Fig. 4f). Deste modo, parece que o "zero atual" foi ultrapassado em torno de 6.600 anos A.P. e que o pico positivo de 5.100 anos A.P. não parece ter ultrapassado a cota de $4 \mathrm{~m}$.

Além das evidências geológicas e biológicas, foi possível, neste setor, contar com datações de vários sambaquis que forneceram informações complementares interessantes sobre a evolução de nivel relativo do mar (MARTIN et al., 1980b, 1980e, 1984d). Além disso, dados sobre

variações de $\delta^{13} C_{(P D B)}$ dos carbonatos de conchas de moluscos, em função do tempo, mostraram que estes parâmetros estão relacionados entre si e com as extensões das paleolagunas e, estas, com as mudanças dos níveis marinhos (FLEXOR et al., 1979).

\subsubsection{Setor de Paranaguá (PR)}

Neste setor, que possui cerca de $50 \mathrm{~km}$ de extensão, foram conseguidas somente algumas reconstruções boas. Entretanto, essas informações associadas a dados de sambaquis, permitiram estabelecer as linhas gerais de variação de nível relativo do mar nos últimos 7.000 anos conforme MARTIN et al. (1986d) (Fig. 4g).

Desta maneira, na Baía de Paranaguá, o topo da porção externa do terraço marinho pleistocênico está situado cerca de 2,5 m acima do nível atual de maré alta. Como são ainda encontrados alinhamentos de cristas praiais no topo desses terraços pleistocênicos, é evidente que eles não foram submersos durante o Holoceno e, portanto, durante o pico positivo máximo de 5.100 anos A.P., quando o nível do mar não poderia estar acima de 2,5 m em relação ao nível de maré alta atual. Dados adicionais fornecidos por sambaquis permitiram concluir que a curva de Paranaguá exibe uma forma semelhante a de Salvador, porém apresenta-se nitidamente deslocada para baixa em relação àquela curva.

\subsubsection{Setor de Itajaí - Laguna (SC)}

Embora, aqui também, boas reconstruções sejam escassas, utilizando-se dados complementares fornecidos pelos sambaquis foi possível obter as tendências gerais de flutuações de nível do mar no setor durante os últimos 7.000 anos A.P. MARTIN et al. (1986d). A curva assim obtida é também semelhante a de Salvador e acha-se igualmente deslocada para baixo, porém menos do que a curva de Paranaguá (Fig. 4h).

\subsubsection{Setor do Estado de Alagoas}

Não foi possível construir uma curva de variação de nível relativo do mar ao longo 
do litoral do Estado de Alagoas, porque as reconstruções mais precisas foram raras e o setor considerado é relativamente longo. Entretanto, as informações obtidas não parecem indicar diferenças dignas de nota em relação à curva de Salvador (BARBOSA et al., 1986a, 1986b).

\subsection{Considerações gerais sobre as curvas}

O primeiro fato importante é que, em todos os setores, o nivel relativo do mar já fol superior ao atual durante o Holoceno, tendo atingido a maior elevação em torno de 5.100 anos A.P. Por outro lado, em todos os setores, parecem ter ocorrido duas rápidas oscilações de vários metros de nivel relativo do mar após 5.100 anos A.P. que são muito acentuadas para serem somente de origem climática. Além disso, embora todas as curvas sejam semelhantes, apresentam maiores ou menores deslocamentos verticais.

Na curva de Salvador, que foi construída com a maior precisão, 17 reconstruções de antigas posições de nivel do mar, utilizadas para se estabelecer a curva nos últimos 2.500 anos, estão situadas sobre uma linha reta. Além disso, outras 8 reconstruções utillizadas para delinear a curva entre 3.600 e 3.000 anos A.P. estão também situadas sobre esta mesma reta. Finalmente, quando se prolonga esta reta até $\mathbf{5 . 1 0 0}$ anos A.P. (pico positivo), obtém-se uma posição de nível do mar situada cerca de $5 \mathrm{~m}$ acima do atual. Por outro lado, experimentalmente fol reconstruida uma antiga posição de nivel relativo do mar que se situava 4,8 $0,5 \mathrm{~m}$ acima do atual há $5.150 \pm 110$ anos A.P. Então, parece que grande número de pontos acha-se situado, entre 5.100 anos A.P. $\theta$ o presente, sobre mesma reta. $\mathrm{O}$ número desses pontos é demasiadamente grande para se tratar de um fenômeno fortuito. Além disso, durante certos períodos a curva experimental afasta-se mais ou menos desta reta. Tudo parece passar como se após 5.100 anos A.P., um primeiro fenómeno tivesse promovido um abaixamento regular de nivel relativo do mar e que segundo fenômeno superposto ao primeiro tivesse provocado oscilação muito rápida neste mesmo nivel do mar.

A comparação do conjunto de curvas obtidas (Fig. 4) mostra que as curvas de Salvador, llhéus e Caravelas não exibem deslocamentos entre si. A curva de Angra dos Reis apresenta um leve deslocamento para baixo, cuja tendência torna-se crescente nas curvas de Santos e Cananéla, atingindo o máximo deslocamento na de Paranaguá. Por outro lado, a curva de Florianópolis apresenta um deslocamento menor do que a de Paranaguá em relação a de Salvador.

\subsection{Natureza dos fenômenos}

Em certos setores, bem delimitados do litoral, têm sido possivel evidenciar 
deslocamentos de linhas de praia holocênicas em conseqüência de movimentos tectônicos verticais. Foi assim que, segundo MARTIN et al. (1984a, 1986b), na Baía de Todos os Santos (BA), situada no graben do Recôncavo, blocos de falhas verticais provocaram deslocamentos muito evidentes nas linhas de praia holocênicas (Fig. 5). Fenômenos semelhantes parecem ter ocorrido, na mesma época, no graben da Guanabara (MARTIN et al., 1980b) e ao sul do Cabo de São Tomé (MARTIN et al., 1984e), ambos no Estado do Rio de Janeiro.

É igualmente possivel que algumas partes do litoral brasileiro tenham sido afetadas por um mecanismo de flexura continental, porém este fenômeno parece não ter influído de maneira considerável na escala de tempo do Holoceno (MARTIN \& SUGUIO, 1976a).

Se a diferença de quase $2,5 \mathrm{~m}$, existente entre as altitudes dos terraços correspondentes ao pico positivo de 5.100 anos A.P. entre os setores de Salvador e de Paranaguá, fosse de origem tectônica, os testemunhos de nivel marinho alto de 123.000 anos A.P. deveriam apresentar diferenças de nível de quase $60 \mathrm{~m}$ entre essas áreas, porém isto não ocorre. Testemunhos de terraços correlacionáveis ao nivel marinho mais alto de 123.000 anos A.P. ocorrem em todos os setores escolhidos para a construção de curvas de variação de nivel do mar durante o Holoceno, excetuando-se o de Angra dos Reis (RJ), mas diferenças desta ordem não são constatadas em nenhum lugar. Portanto, esses deslocamentos devem ser uma conseqüência de deformações na superfície do geóide.

Examinando-se a carta geoidal do Brasil (Fig. 6), verifica-se que a porção oriental do Brasil está situada sobre uma protuberância do geóide, cujas linhas de isoelevação estão dispostas aproximadamente na direção norte-sul. Pode-se também perceber, que a porção ocidental do Brasil está localizada sobre uma outra protuberância centrada na Bolfvia e que entre essas duas intumescências existe uma depressão que atravessa o litoral norte e sudeste do pals. A parte do litoral do Estado da Bahia, sobre a qual estão os setores que fornecem os dados para as curvas de Salvador, llhéus e Caravelas, de direção aproximadamente N-S, é mais ou menos paralela às linhas de isoelevação geoidal.

Por outro lado, as partes do litoral que contém os setores que forneceram os dados para as curvas de Angra dos Reis, Santos, Cananéia e Paranaguá, de direção aproximadamente NESW, cortam obliqüamente as linhas de isoelevação geoidal. Um desiocamento horizontal segundo as direções N-S ou E-W do relevo geoidal não causará quaisquer defasagens no primeiro conjunto, mas introduzirá desvios no segundo conjunto de curvas (Fig. 7). Se esta hipótese estiver correta, os niveis marinhos holocênicos do norte do Brasil deveriam estar igualmente desviados em relação aos níveis correspondentes da região de Salvador. Infelizmente, ainda não se dispõe de reconstruções de niveis marinhos pretéritos para esta parte do litoral. Entretanto, é interessante notar que o litoral entre São 

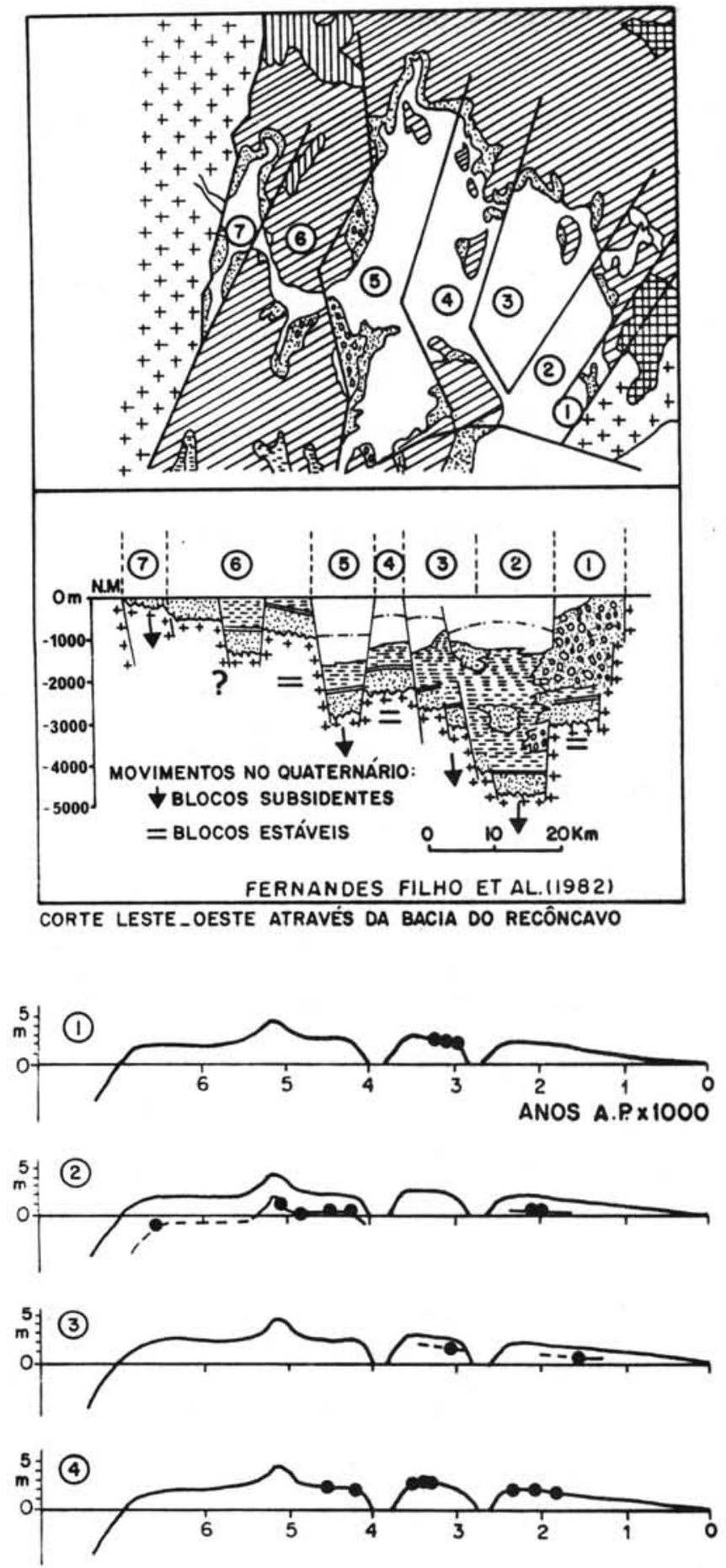

Figura 5 - Evidências de tectonismo holocênico, na região da Baía de Todos os Santos (BA) vendo-se, de cima para baixo, mapa geológico esquemático com blocos de falhas e o perfil transversal às falhas (FERNANDES FILHO et al., 1982) e, finalmente, os paleoníveis marinhos reconstruídos através de dados obtidos nos blocos 1 a 4 (MARTIN et al., 1984a). 


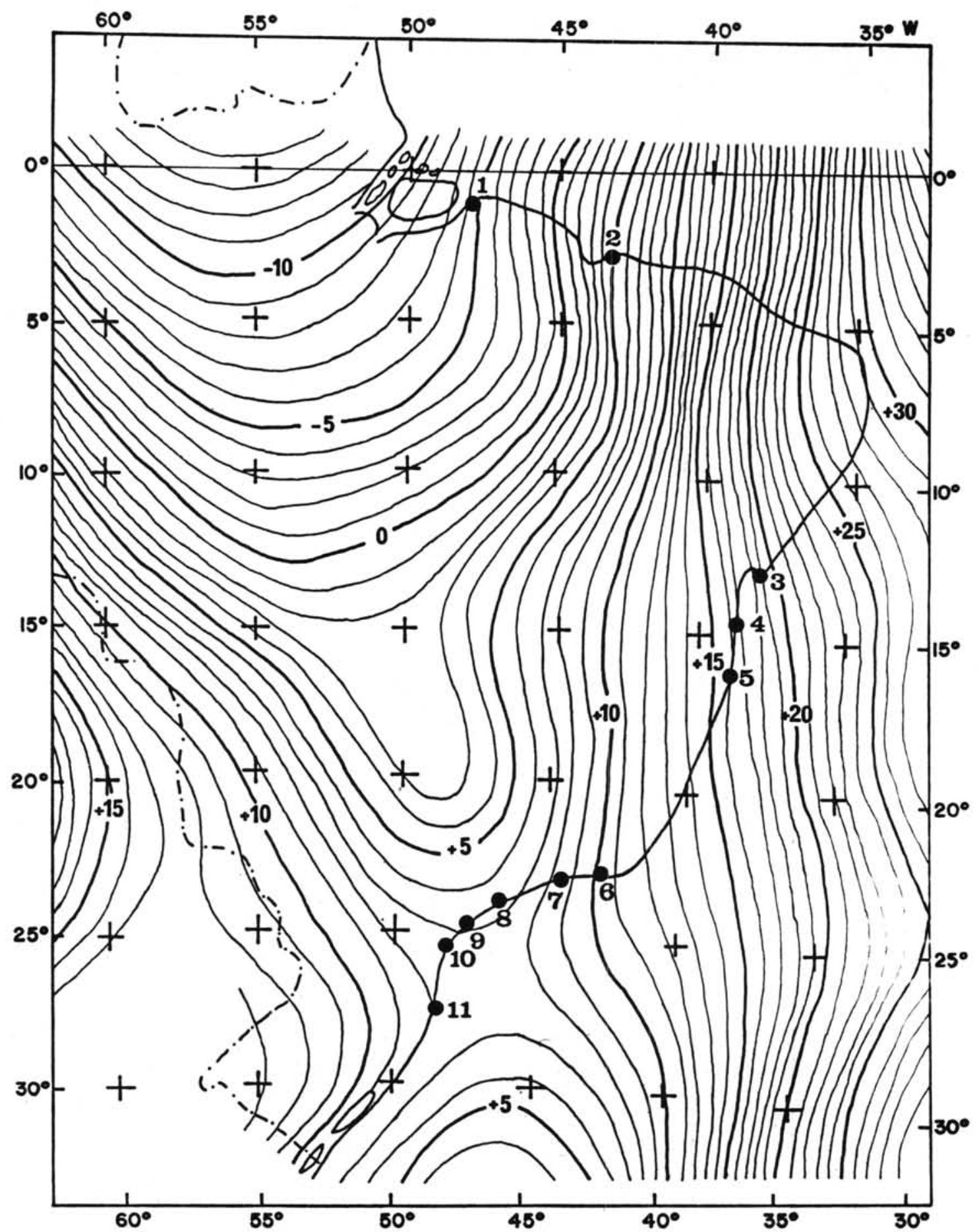

Figura 6 - Carta geoidal do Brasil com as configuraçōes atuais das curvas de isoelevação (em metros) $\theta$ as localizaçōes aproximadas das cidades de Belém (1), São Luís (2), Salvador (3), llhéus (4), Caravelas (5), Rio de Janeiro (6), Angra dos Reis (7), Santos (8), Cananéia (9), Paranaguá (10) e Itajaí (11). 
Luís e Belém, por exemplo, apresenta feições mais sugestivas de submersão, sendo constituídas de costas recortadas com falésias vivas entalhadas em sedimentos da Formação Barreiras e com os cursos inferiores de rios transformados em verdadeiras "rias".

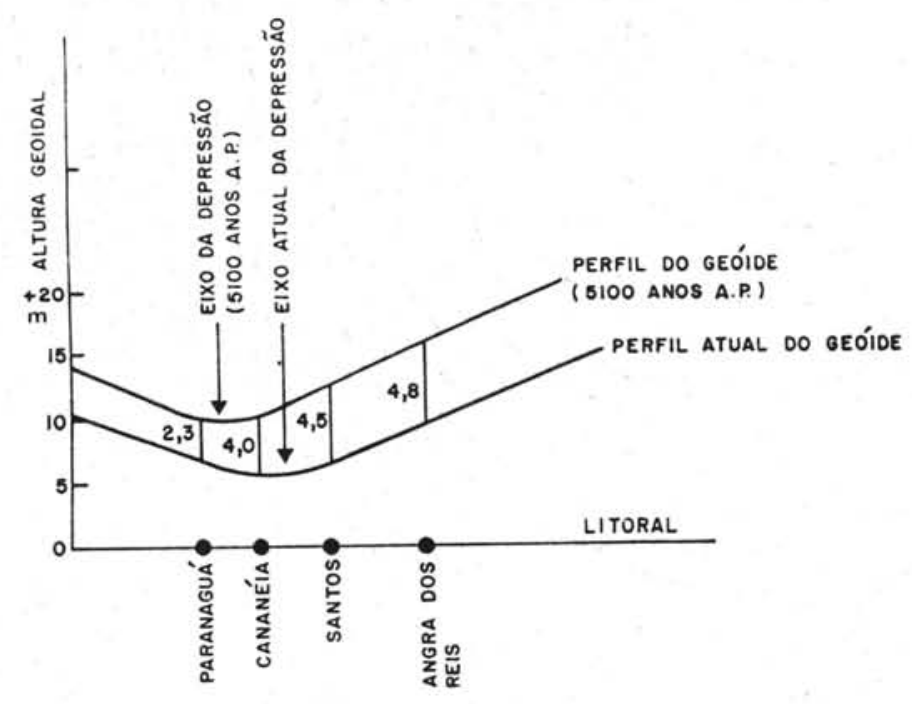

Figura 7 - Comparação entre os perfis das superfícies geoidais atual e de 5.100 anos A.P. As diferenças verticais de amplitude (em metros) podem ser creditadas à subsidência da superfície geoidal acompanhada de leve deslocamento da depressão central para leste (MARTIN et al., 1985a).

Parece que os niveis marinhos holocênicos mais altos do que o atual do Brasil, que não podem ser de origem glácio-eustática nem tectônica, podem ser explicados em parte pelo levantamento regional do conjunto do relevo geoidal até cerca de 5.100 anos A.P., seguido por abaixamento acompanhado por pequeno deslocamento horizontal para leste. Do mesmo modo, um abaixamento regional do conjunto do relevo geoidal, seguido por levantamento na escala de centenas de anos, poderia explicar as oscilações rápidas produzidas após 5.100 anos A.P., que também não podem ser glácio-eustáticas nem tectônicas. Em suma, pode-se dizer que as costas nordeste, oriental e sudeste brasileiras tenham estado sujeitas à submersão até cerca de 5.100 anos A.P., seguida de emersão. Esta situação não é encontrada, por exemplo, na costa atlântica e do Golfo do México dos Estados Unidos, onde o nivel relativo do mar nunca fol superior ao atual nos últimos 7.000 anos (Fig. 8). Desta maneira, a evolução litorânea no período não fol a mesma nas costas orientais dos Estados Unidos e do Brasil. Enquanto o litoral dos Estados Unidos é caracterizado por um sistema de llhasbarreiras/lagunas, nas costas do Brasil desenvolvem-se extensos terraços arenosos de cristas praiais. 


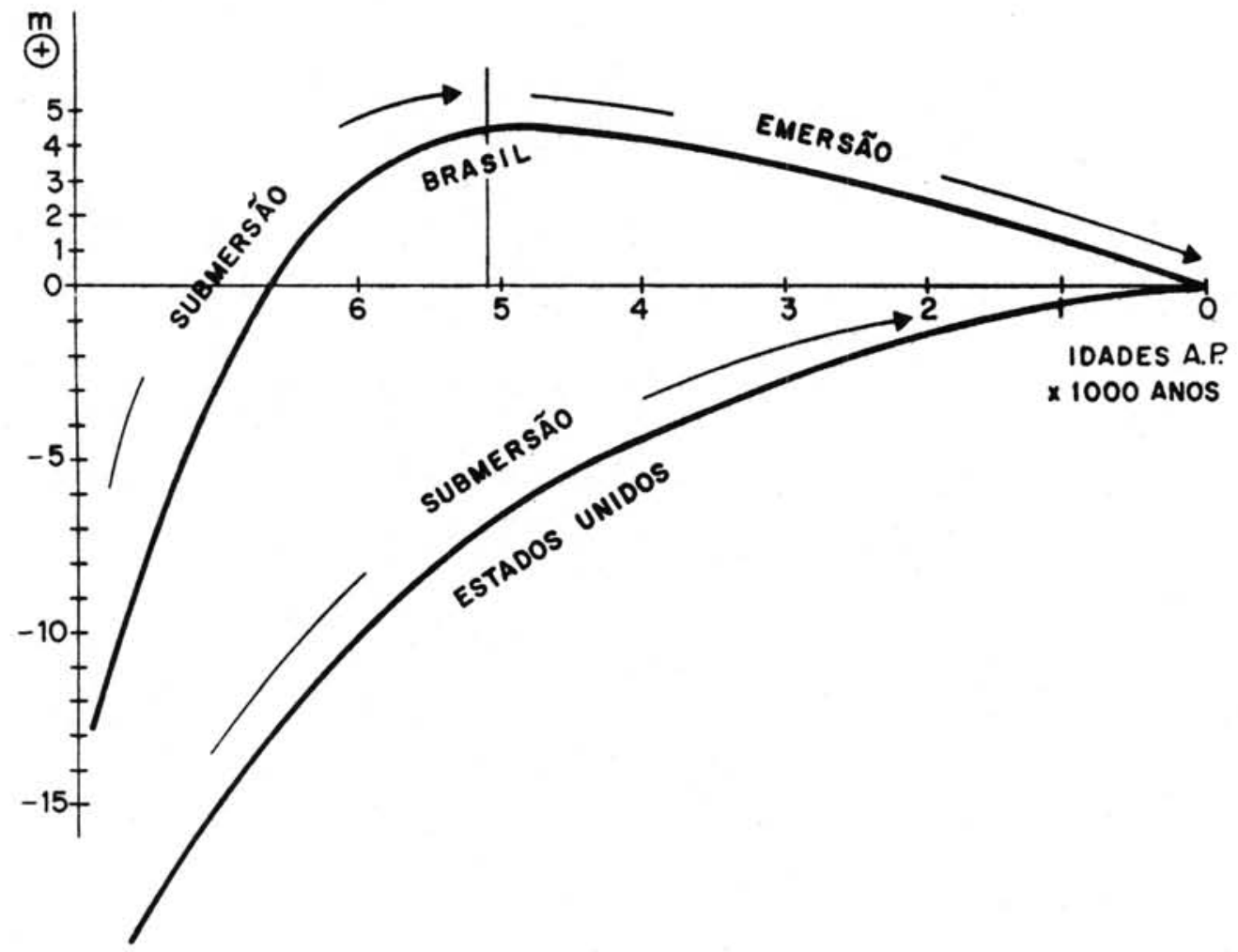

Figura 8 - Curvas esquemáticas médias das variaçóes de nível relativo do mar na porção central do litoral brasileiro e na costa sudeste dos Estados Unidos de 7.000 anos A.P. até hoje. 


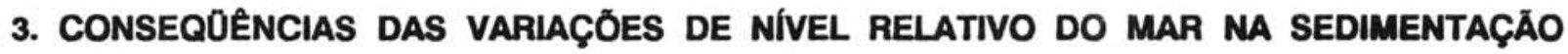 COSTEIRA ARENOSA}

\subsection{Papel das variaçóes de nivel relativo do mar}

A regra de BRUUN (1962) estabelece que, uma vez atingido o perfil de equilibrio da zona litoranea, uma elevação subseqüente de nivel relativo do mar irá perturbar este equilibrio, que será então restaurado mediante translação rumo ao continente (Fig. 9). Em conseqüência disso, o prisma pralal irá sofrer erosão e o material erodido será transferido e depositado na antepraia. Esta transferência provocará uma elevação do assoalho da antepraia de magnitude $a_{1}$, igual à elevação sofrida pelo nivel do mar $\mathrm{a}_{2}$, mantendo-se assim constante a espessura da lâmina de água.

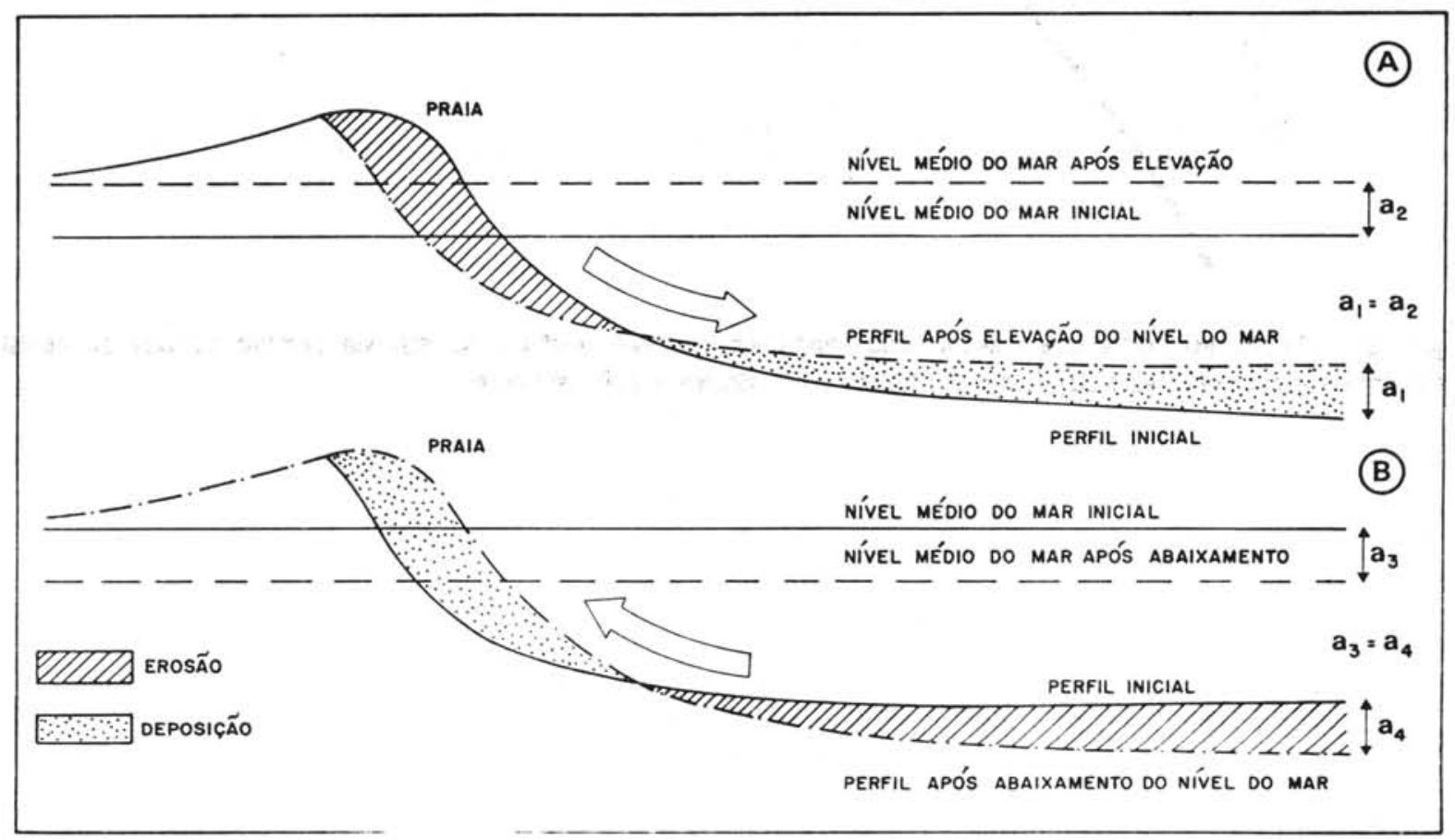

Figura 9 - (A) Comportamento do perfil de equilibrio da zona litorânea em função da elevação de nível relativo do mar (modificado de BRUUN, 1962) e (B) Comportamento do mesmo perfil em função da descida de nível relativo do mar (DOMINGUEZ, 1982).

Testes de campo e de laboratório, executados por SCHWARTZ $(1965,1967)$ e DUBOIS (1976, 1977) comprovaram a hipótese de BRUUN (op.cit.). Embora esta regra tenha sido 
proposta para fases de subida de nivel do mar, também parece ser válida para a situação inversa, isto é, o equilibrio desfeito deverá ser restaurado também quando ocorre a descida de nivel do mar. De fato, o ababxamento de nivel relativo do mar, diminuindo a espessura da lâmina de água, Irá gerar desequilibrio no perfil da zona litorânea tornando-o mais "agradado". Em conseqüência, as ondas irão movimentar os sedimentos inconsolidados da antepraia rumo ao prisma praial e provocando, desta maneira, progradação da linha de costa. Esta transferéncia de material irá cessar somente quando a profundidade for equivalente à que existia anteriormente. Comparativamente, este processo é semelhante àquele no qual um perfil de tempestade recupera-se por transferência de sedimentos da antepraia para o prisma praial em perfil de ondulação (swell profile), processo este amplamente discutido na literatura (DAVIES, 1972; KING, 1972: KOMAR, 1973; SWIFT, 1976). De maneira análoga, este mecanismo é verificado durante o ciclo mensal das marés. Durante as marés de sizigla, correspondentes a uma "pequena transgressão", ocorre erosão na pós-praia e, em contrapartida, durante as marés de quadratura, comparáveis a uma "pequena regressão", ocorre sedimentação na pós-praia.

\subsection{Papel das correntes de deriva litorânea}

O transporte de sedimentos ao longo de uma praia arenosa é promovido principalmente pelas correntes de deriva litoranea geradas pelas ondas. De fato, proximo às praias, as ondas não encontram profundidades suficientes para a sua propagação, ocorrendo então a sua arrebentação. Este fenômeno é acompanhado pela liberação de grande quantidade de energia, que será traduzida em parte na colocação em suspensão das arelas e parcialmente na formação de correntes de deriva litorânea. Naturalmente, este fenômeno ocorrerá se as ondas atingirem obliqüamente a linha de prala. A velocidade desta corrente é lenta, mas a sua ação se faz sentir em uma zona onde as areias foram colocadas em suspensão pela arrebentação das ondas e, portanto, 0 volume de areia transportado por este mecanismo será considerável.

Vários cálculos mostraram que a velocidade da corrente de deriva litorânea é máxima quando as ondas atingirem a linha de praia com ângulos variando entre 46 e $58^{\circ}$ (LARRAS, 1961). A ação conjunta das águas de espraiamento, de arrebentação das ondas $\theta$ das correntes de deriva litorânea provoca o transporte pulsatório das areias. Evidentemente, o sentido de transporte dependerá da direção de incidência das frentes de ondas que atingem a praia.

Certamente, durante um período de ababcamento de nivel relativo do mar, parte da arela fornecida para o restabelecimento do perfil de equilibrio irá transitar ao longo da praia como conseqüência deste mecanismo. Este transporte prosseguirá até que as areias sejam retidas por uma 
armadilha ou bloqueadas por um obstáculo. Isto explica as grandes diferenças que podem existir em uma região submetida a abaixamento uniforme de nível do mar. Os depósitos arenosos serão pouco desenvolvidos ou mesmo ausentes nas zonas onde há predominância de trânsito litorâneo e multo importantes nas regiōes onde um obstáculo ou uma armadilha tenha permitido a retenção das areias. Estas armadilhas podem ser de diferentes tipos, tais como, reentrancias na linha costeira, lihas ou fundos rasos (baixios) formando zonas de baixa energia, pontões do embasamento cristalino, desembocaduras fluviais de rios importantes, etc.

3.3. Bloqueio de transporte litorâneo de sedimentos arenosos por fluxo fluvial junto à desembocadura

Em determinadas condições, o fluxo de água junto à desembocadura de um rio poderá constituir um obstáculo, que tenderá a bloquear o transporte das areias, do mesmo modo que um molhe artificial em uma região costeira. Essas estruturas martimas, ancoradas em terra, são geralmente construídas de modo a estender-se além da zona de arrebentação impedindo completamente o trânsito litorâneo de sedimentos. Como resultado, os sedimentos ficarão retidos de encontro ao molhe, fazendo com que a linha de costa a barlamar desta estrutura prograde rapidamente. A sotamar, a corrente de deriva litorânea continua atuante, removendo os sedimentos $\theta$ provocando o avanço do mar por erosão da linha de costa. KOMAR (1973) desenvolveu modelos de computador para simular o crescimento $\theta$ a forma de equilibrio dos deltas nos quals a açăo das ondas é a força dominante na redistribuição dos sedimentos. Deste modo, este autor chamou a atenção para o fato de que, em presença de ondas que se aproximam da costa segundo um ângulo agudo, o fluxo fluvial se comporta à semelhança de um molhe constituindo uma barreira à deriva litorânea. Assim, a planície litorânea à barlamar da desembocadura prograda muito mais rapidamente do que à sotamar que, por sua vez, irá caracterizar-se como uma região com "déficit" de sedimentos.

Os mecanismos atuantes na foz de um rio podem ser esquematizados da seguinte maneira (Fig. 10):

a) Em periodo de alta descarga fluvial, correspondente a fase de enchente, o fluxo de água junto à desembocadura irá constituir um obstáculo que tenderá a bloquear o transporte litorâneo das areias. Isto irá ocasionar acumulação de arelas à barlamar da foz e possivel erosão à sotamar. Entretanto, a erosão da porção à jusante da corrente é freqüentemente compensada pelo aporte de sedimentos grossos supridos pelo próprio rio.

b) Em período de baixa descarga fluvial, o obstáculo representado pelo fluxo fluvial irá praticamente desaparecer e conseqüentemente, a meia-cúspide construída à barlamar, na fase 
anterior, experimentará acelerado processo de erosão. Os sedimentos erodidos serão desiocados para sotamar, originando um esporão arenoso que tenderá a obstruir parcialmente a foz. Este evento ficará registrado na planície costeira sob a forma de uma linha de truncamento das cristais pralais. Se o período de baixa vazão durar bastante tempo o esporão arenoso poderá atingir largura suficiente que permitirá resistir, até certo ponto, às condições de alta energia da fase de enchente subseqüente. Multas vezes, somente a extremidade do esporáo arenoso poderá ser destruída e a barragem provocada pelo fluxo fluvial será deslocada no sentido da deriva litorânea. Sobre a linha de truncamento, a barlamar da desembocadura, será construldo um novo sistema de cristas praials alimentado pelos sedimentos transportados ao longo da costa.

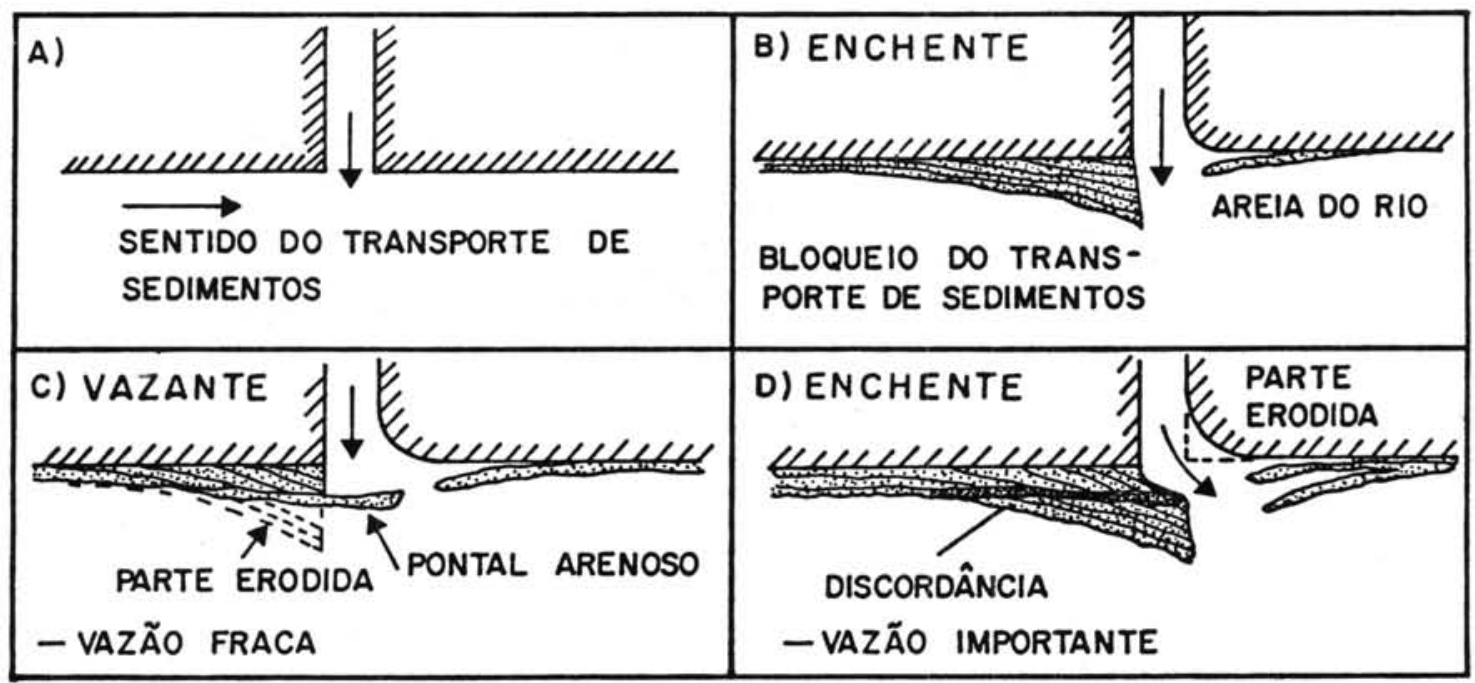

Figura 10 - Mecanismo de bloqueio do transporte litorâneo de areias, paralelamente à costa, por efeito de fluxo ligado a uma desembocadura fluvial em regiōes costeiras, exibindo alternância de fases de débitos fluviais.

Em conseqüência deste fenômeno, pode-se verificar o aparecimento de forte assimetria entre as partes da planície costeira situada de um lado e de outro da desembocadura. Enquanto à barlamar da desembocadura a linha de costa avança à custa da incorporação gradativa de sedimentos arenosos trazidos por deriva litorânea, à sotamar, a progradação se processa principalmente em função dos aportes fluviais. Neste processo, podem ser desenvolvidos esporões arenosos na margem da desembocadura, à sotamar, pelo retrabalhamento de barras de desembocadura que, por ação de refração de ondas, evoluem para ilhas lunadas. Uma vez formadas, essas ilhas e esporões passam a formar zonas protegidas na sua porção interna, que são rapidamente 
colonizadas por manguezais e passam a captar os sedimentos finos carreados pelo rio. Além disso, os desiocamentos da desembocadura são marcados por uma sucessão de degraus realçados por discordâncias nos alinhamentos das cristas praiais. Deste modo, a parte da planicie à barlamar será formada por fabcas de cristas praiais essencialmente de origem marinha, enquanto que a porçăo à sotamar será constitulda por uma alternâncla de fabcas arenosas de origem fluvilal entremeadas por zonas babxas areno-argilosas.

Quando as frentes de onda incidem paralelamente à linha de praia, e somente neste caso, os sedimentos transportados pelos cursos fluvials defronte de sua desembocadura serăo retrabalhados e depositados em ambos os lados da foz para formar um delta em cúspide altamente destrutivo dominado por ondas (Fig. 11).

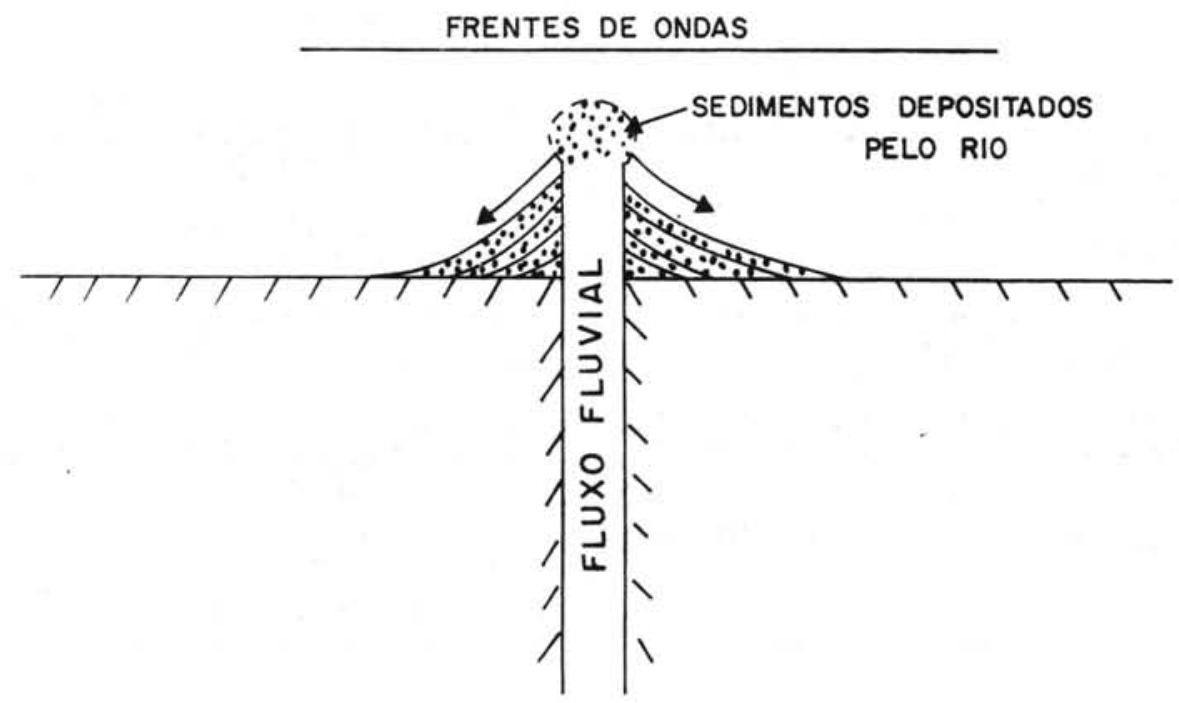

Figura 11 - Em desembocaduras fluviais, onde as frentes de onda incidem paralelamente à linha costeira, há ausência de transporte litorâneo $\theta$ as areias fornecidas por aporte fluvial são redistribuídas pelas ondas em ambas as margens da foz, com disposição aproximadamente simétrica. 


\section{CARACTERÍSTICAS GEOLÓGICAS E EVOLUÇÃO NO QUATERNÁRIO DA COSTA BRASILEIRA ENTRE OS ESTADOS DE ALAGOAS E SANTA CATARINA}

\subsection{Quadro físico}

O trecho da costa brasileira aqui enfocado está contido total ou parcialmente em três das cinco unidades morfológicas de subdivisão do litoral admitidas por SILVEIRA (1964), a saber: Ltoral Nordestino ou das Barreiras (desde o Maranhão Oriental ao Recôncavo Baiano), Ltoral Oriental (do Recôncavo Baiano ao sul do Espírito Santo) $\theta$ o Litoral Sudeste ou das Escarpas Cristalinas (do sul do Espirito Santo à região de Laguna em Santa Catarina), Figura 12.

\subsubsection{Litoral Nordestino ou das Barreiras}

a) Morfologia

O traço comum que caracteriza este trecho da costa é a presença de depósitos sedimentares terciários continentais da Formação Barreiras (BIGARELLA \& ANDRADE, 1964; BEURLEN, 1967; MABESOONE et al., 1972; BIGARELLA, 1975a). Esses depósitos desenvolvem uma superfície mais ou menos plana, dissecada pela drenagem e suavemente inclinada para o oceano, separando a região costeira da região sublitorânea e terminando junto ao mar em costas escarpadas de falésias. A Formação Barreiras repousa, na maior parte, sobre superfícies aplainadas do embasamento cristalino pré-cambriano, embora localmente o substrato possa ser representado por rochas sedimentares cretácicas, como acontece em Cabo Branco (PE) ou na região do Recôncavo Baiano. Calcários marinhos cretácicos e terciários, representados respectivamente pelas formações Gramame e Maria Farinha, afloram freqüentemente intercalados entre a Formação Barreiras $\theta$ o embasamento cristalino, a uma altitude próxima à do nivel marinho atual.

Outra feição bastante freqüente neste litoral é a presença de arenitos de praia (beach rocks) estudados em maior detalhe por BRANNER (1904) e, mais recentemente por MABESOONE (1964), FERREIRA (1969), BIGARELA (1975b) ө FLEXOR \& MARTIN (1979).

Por outro lado, assumem importância considerável neste trecho da costa brasileira, principalmente ao sul do Rio Grande do Norte, as formaçőes coralinas que podem apresentar-se na forma de recifes com 15 a $50 \mathrm{~m}$ e excepcionalmente $100 \mathrm{~m}$ de largura (LABOREL, 1969). Săo menos freqüentes ao sul da costa nordestina e a partir da desembocadura do Rio São Francisco praticamente desaparecem.

No litoral Nordestino a plataforma continental é plana e estreita. 


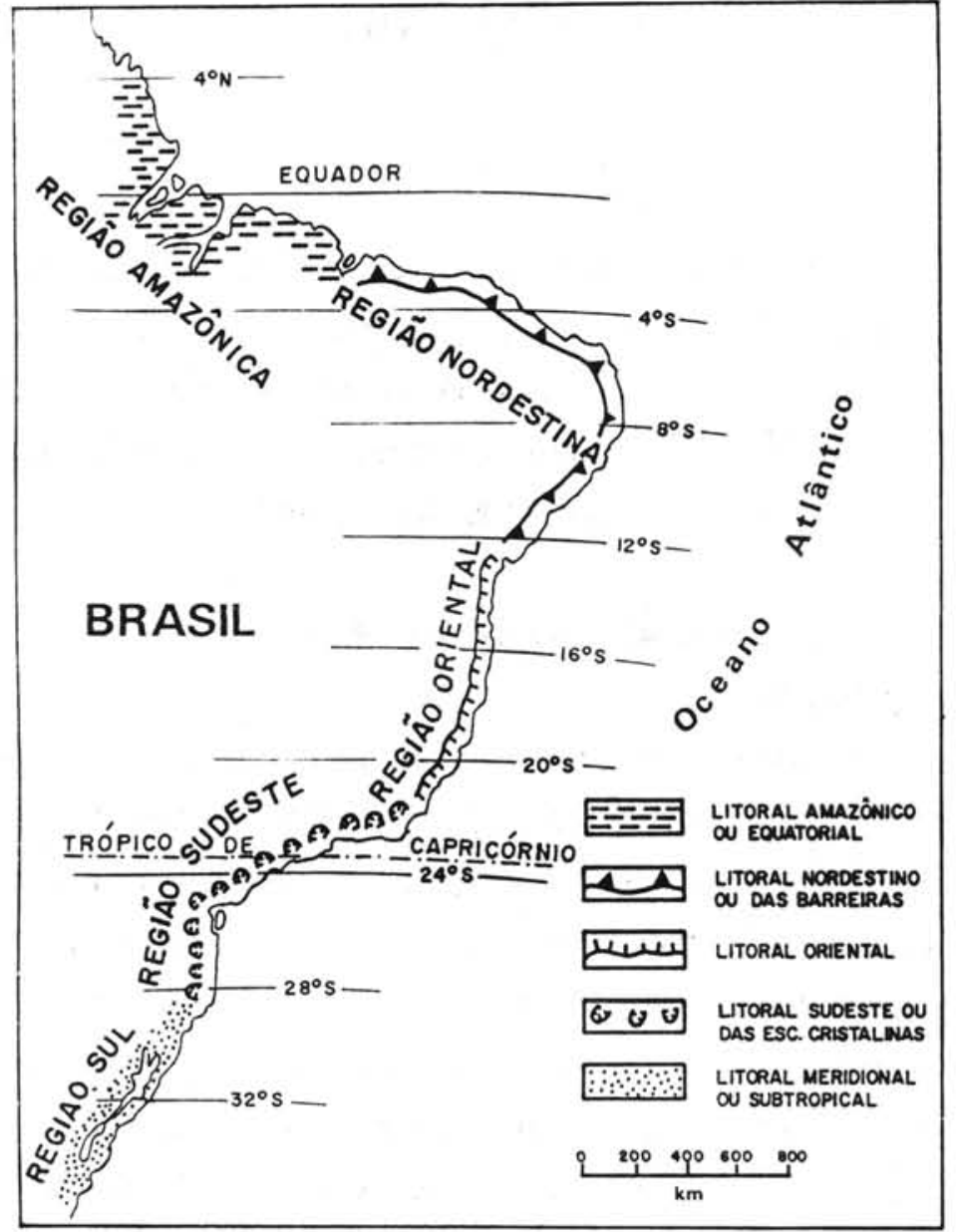

Figura 12 - Classificação do litoral brasileiro por SILVEIRA (1964), baseada em elementos oceanográficos, climáticos e continentais.

\section{b) Clima}

O primeiro trecho, compreendido entre o Maranhão Oriental e o Rio Grande do Norte, de direção WNW-ESE e o segundo trecho, de direção N-S e NNE-SSW, distinguem-se tanto sob aspectos oceanográficos quanto climáticos.

Primeiro trecho é submetido, em sua maior parte, a um regime climático semi-árido com precipitação pluviométrica que, em alguns pontos, não excede aos $500 \mathrm{~mm} / \mathrm{ano}$, sendo intensamente batido por ventos alísios alternantes de SE e de NE. As condições climáticas e o suprimento de grandes volumes de areias, provavelmente provenientes da plataforma continental, arremessadas continuamente contra o litoral pelas grandes vagas de ENE, tornam as águas costeiras 
muito turvas e propiciam a sedimentação de amplas faixas de dunas é́licas. Essas dunas eólicas, que por vezes, atingem aituras superiores a $30 \mathrm{~m}$, dificultam o escoamento de escassas águas interiores.

O segundo trecho, que se estende de Natal a Salvador, caracteriza-se por clima úmido (2.000 mm/ano no litoral pernambucano), com estações chuvosas de abril e outono e secas de novembro a março. Ao sul do Rio São Francisco o clima torna-se consideravelmente mais seco, propiciando o desenvolvimento de faixa quase contínua de dunas eólicas desprovidas de vegetação que se estende até Salvador.

c) Vegetação

No interior de baías e estuários, de águas calmas, desenvolvem-se manguezais, compostos por uma associação mais ou menos homogênea de vegetais, onde predominam as seguintes espécies: Rhyzophora mangle, Laguncularia racemosa, Avicennia schaueriana e Spartina alterniflora (DIAS-BRITO \& ZANINETTI, 1979).

No trecho da costa nordestina, de clima semi-árido, a partir da faixa de vegetação litorânea passa-se, rumo ao interior, diretamente para as formações de caatingas, que são características de áreas de clima semi-árido (Bsh DE KÖPPEN, 1948). Na porção oriental da costa nordestina, do Cabo de São Roque(RN) ao Recôncavo Baiano, entre a vegetação litorânea e a caatinga, desenvolvem-se as florestas latifoliadas tropical e/ou tropical úmida de encosta (Mata Atlântica).

\section{d) Hidrografia}

A maior parte da costa nordestina é drenada por rios formadores da chamada Bacia do Nordeste, caracterizada por pequenas bacias hidrográficas independentes e tributários diretos do Oceano Atlântico (rios Jaguaribe, Capibaribe, etc.). São relativamente pouco extensos e caracterizados por regimes subequatoriais. O Rio Jaguaribe, um dos maiores, tem cerca de $450 \mathrm{~km}$ de extensão. Quando grande parte da bacia situa-se mais para o interior, os rios exibem um regime mais tropical, enquanto que os mais litorâneos caracterizam-se por regime diferente daqueles.

O único rio não pertencente à Bacia do Nordeste é o Rio São Francisco, que se estende do sul para o norte por cerca de $2.700 \mathrm{~km}$ através de planaltos com 400 a $1.000 \mathrm{~m}$ de altitude. Portanto, este é um típico rio de planalto com regime tropical, isto é, com débitos altos e baixos, correspondentes respectivamente a chuvas de verão e períodos secos de inverno enquanto que nas cabeceiras, em Minas Gerais, o índice pluviométrico anual atinge 1.000 a $2.000 \mathrm{~mm}$, mais para jusante corre por áreas de baixa pluviosidade, freqüentemente inferior a $500 \mathrm{~mm}$ anuais. 


\subsubsection{Litoral Oriental}

a) Morfologia

Este litoral é caracterizado pela continuidade de muitas das características do Litoral Nordestino, tais como, os tabuleiros da Formação Barreiras, os arenitos de praia (beach rocks) e as formações coralinas. Afloramentos de rochas cristalinas, só muito raramente, interferem nas áreas litorâneas, pois as escarpas do Planalto Atlântico apresentam-se muito afastadas da linha de costa. São freqüentes os trechos com sedimentação quaternária mais ou menos extensa e apenas na altura, de Vitória (ES), os contrafortes do Planalto Atlântico atingem a orla marítima.

Feição notória do Litoral Oriental é a presença de platôs submarinos, que passam repentinamente da isóbata de mais de $400 \mathrm{~m}$ para menos de $50 \mathrm{~m}$, dando origem a um substrato ideal para o desenvolvimento de recifes coralinos. Isto acontece, por exemplo, no Arquipélago de Abrolhos, BA (LEÃO, 1982), que representa o local de máximo desenvolvimento e o limite sul das formações coralinas. Deste modo, a plataforma continental que é estreita em frente a llhéus, alarga-se repentinamente em Belmonte, atingindo a largura máxima de $80 \mathrm{~km}$.

b) Clima

O clima é tipicamente úmido e a pluviosidade de 500 a $1.000 \mathrm{~mm}$ na porção norte, chega a mais de $2.000 \mathrm{~mm}$ em llhéus (BA). O clima é tropical, caracterizado pelas chuvas de verão, mas os períodos secos de outono e inverno podem ser perturbados por precipitações frontais das descargas devidas às frentes polares. Desta maneira, segundo ANDRADE (1964), o clima seria uma variedade Aw ("pseudo-equatorial" da costa oriental), com duas máximas pluviométricas anuais, além das chuvas de verão.

c) Vegetação

$\mathrm{Na}$ faixa litorânea predominam vegetações caraterísticas da faixa costeira que, antes de atingirem as zonas das caatingas, passam por áreas de florestas latifoliada tropical e/ou latifoliada tropical úmida de encosta, preservando ainda as peculiaridades da costa nordestina oriental. Pode-se chegar, em alguns trechos, a um clima "pseudo-equatorial" com desenvolvimento de uma verdadeira floresta tipo amazônico, como acontece na planície sedimentar da foz do Rio Doce (ES).

d) Hidrografia

Da mesma maneira que os rios da Bacia do Nordeste, os rios da Bacia do Leste (rios Paraguaçu, Contas, Jequitinhonha, Doce, etc.) são também tributários diretos do Oceano Atlântico. Esses rios apresentam um regime subequatorial, à semelhança dos rios da costa nordestina oriental, diferenciando-se dos que possuem regimes equatorial e tropical típicos. 


\subsubsection{Litoral Sudeste}

a) Morfologia

Este litoral, que se estende desde o sul do Estado do Espirito Santo até à altura de Laguna (SC) é caracterizado por escarpas do Planalto Atlântico, constituidas de rochas cristalinas précambrianas, que freqüentemente chegam até o mar.

Embora no Espírito Santo e Rio de Janeiro, sejam ainda, de certo modo, comuns as planícies costeiras mais ou menos desenvolvidas, da Bala da Guanabara até o Estado do Paraná, o litoral apresenta em geral só planícies costeiras relativamente pouco desenvolvidas $\theta$ delimitadas por pontőes do embasamento cristalino. Nesta porção, as planicles costeiras mals importantes são as de Cananéia-Iguape em São Paulo e de Paranaguá-Antonina no Paraná.

b) Clima

Segundo ANDRADE (1964), o clima deste litoral é caracterizado por variedades do tipo Cf (Subtropical) de KÖPPEN (1948), com inverno seco sem ou com verão brando. Além disso, manifesta-se o efeito orográfico da fachada atlântica causando indices pluviométricos de 2 a 4.000 $\mathrm{mm} / \mathrm{ano}$ em certas regiōes de São Paulo e Rio de Janeiro.

c) Vegetação

Nas planícies costeiras arenosas existem as formações litorâneas. Na zonas protegidas de estuários e balas existem os manguezais até a altura de Laguna (SC), quando são substituídos pela predominância de gramíneas do tipo Spartina alterniflora. Nas encostas do Planalto Atlântico, ocorre a floresta latifoliada tropical de encosta, que é quase tão rica e variada quanto a amazônica, mas as árvores nunca atingem o mesmo porte.

d) Hidrografia

Os rios do Litoral Sudeste pertencem parcialmente à Bacia de Leste (Paraiba do Sul) e à Bacia do Sudeste (Ribeira de Iguape, Itajaí e Tubarão), sendo também todos tributários diretos do Oceano Atlântico. Alguns desses rios apresentam regime tropical típico (Parafba do Sul) e outros exibem regime subtropical com duas estações de altas águas (rios da Bacia do Sudeste).

\subsection{Quadro estrutural (Fig. 13)}

\subsubsection{Generalidades}

O território brasileiro ocupa parte da chamada Plataforma Sul Americana (ALMEIDA, 1969, 1971, 1976), cuja derradeira reativação tectônica mais significativa findou no inicio do Fanerozóico. Esta plataforma, composta de rochas metamórficas e igneas predominantemente précambrianas, constitui o núcleo cristalino do continente. Ela ocupa uma superfície de cerca de 4,6 $x$ $10^{6} \mathrm{~km}^{2}$, subdividida em três extensos escudos: Guianas, Brasil Central e Attântico. 


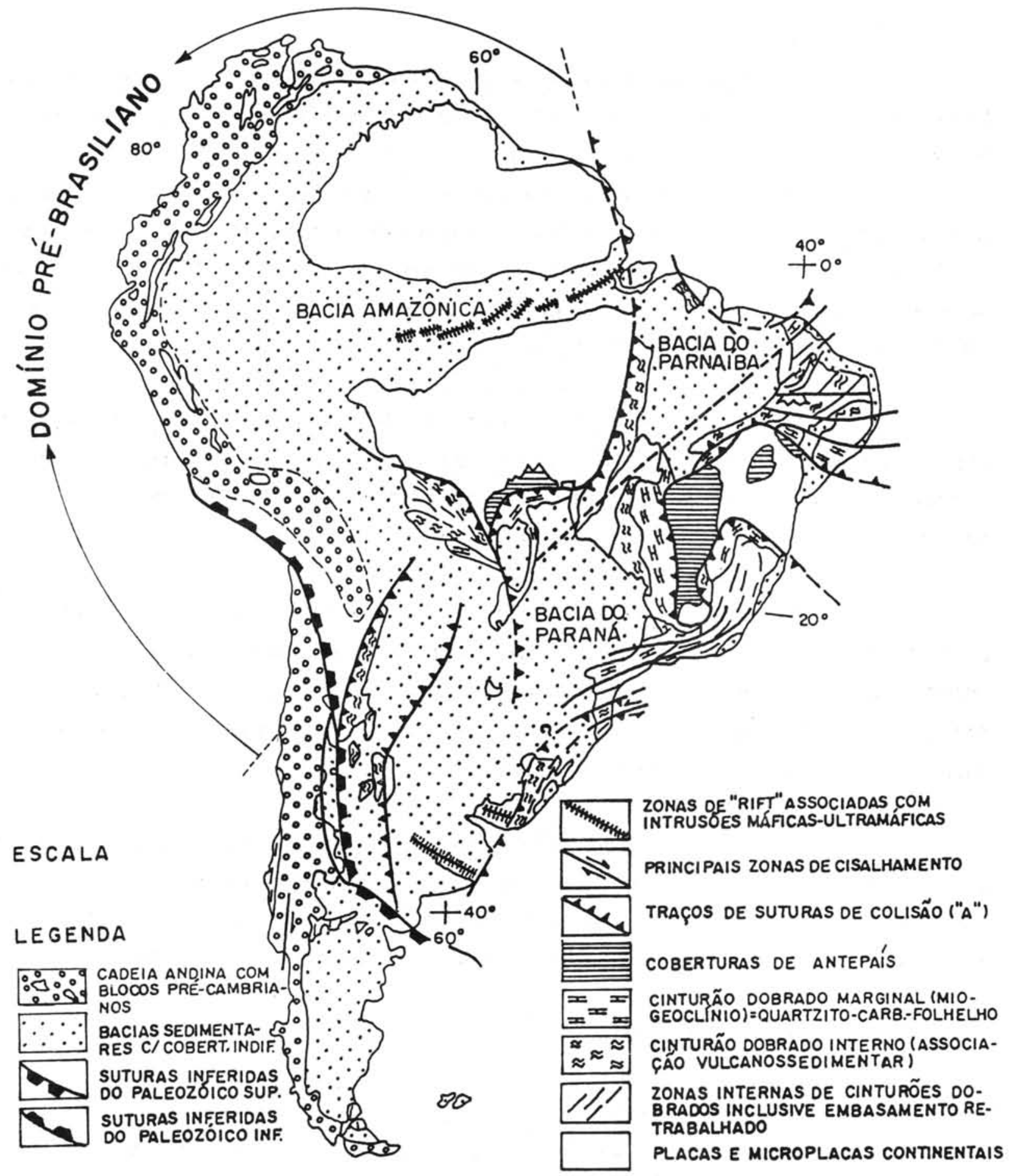

Figura 13 - Quadro estrutural esquemático relacionado à evolução geológica da América do Sul durante o Proterozóico superior (BRITO NEVES \& CORDANI, 1991). 
Grande parte das coberturas sedimentares e vulcanossedimentares, cujas idades mais antigas remontam ao Siluriano inferior, preenche três amplas bacias sedimentares em forma de sinéclise: Amazonas, Parnaíba (ou Maranhão) e Paraná. Áreas restritas dos escudos são ocupadas por coberturas sedimentares de diferentes idades, inclusive pré-cambrianas (ALMEIDA, 1969).

A reativação da plataforma, que se processou do Jurássico superior ao Cretáceo inferior e foi designada Wealdeniana por ALMEIDA (1969), ocasionou a fragmentação do antigo continente do Gondvana, originando várias bacias sedimentares distribuídas ao longo da margem continental atlântica.

\subsubsection{Bacias marginais}

As feições geológicas mais conspícuas da costa leste e nordeste do Brasil são representadas pelas bacias marginais, que foram delineadas por falhas normais ocorridas principalmente durante o Eocretáceo.

A partir das informações provenientes de superfície e subsuperfície, ASMUS \& PONTE (1973) estabeleceram uma coluna-padrão para as bacias marginais brasileiras, que pode ser subdividida em várias seqüências. ASMUS (1979) reconheceu na coluna-padrão dessas bacias as seqüências que receberam as seguintes denominações informais:

a) Seqüência do continente - Composta de folhelhos vermelhos intercalados por arenitos arcosianos subordinados, com arenitos finos e conglomeráticos superpostos. Esta seqüência, segundo PONTE et al. (1971), teria sido depositada em bacia intracratônica alongada de direção nortesul, denominada Depressão Afro-Brasiliana. Segundo MUNNE et al. (1972), representaria depósitos de leques aluviais e de lagoas interiores, com predominância de períodos de relativa quiescência tectônica. A idade admitida para a seqüência é neojurássica (Purbeckiano).

b) Seqüência dos lagos - Formada por uma alternância de folhelhos e arenitos com intercalações subordinadas de calcário. GAMA JÚNIOR (1970) sugeriu que a deposição ter-se-ía processado em ambiente deltaico lacustre, como resultado de preenchimento de bacias tectônicas delimitadas por falhas normais, que controlaram a distribuição faciológica e perturbaram os sedimentos depositados. A atividade tectônica ligada à deposição desta seqüência pode ser associada à Reativação Wealdeniana de ALMEIDA (1969).

c) Seqüência do golfo - Os sedimentos que caracterizam esta seqüência compreendem rochas clásticas e carbonatos depositados em ambiente transicional e evaporitos, com predominância de anidrita e halita.

A migração do sal produziu estruturas halocinéticas espetaculares, domos em particular, na faixa de ocorrência de evaporitos. Pela freqüência e pelas dimensões, destacam-se os 
domos salinos das bacias de Santos, Campos, Espirito Santo e Bahia Sul. Os llmites norte e sul de ocorrência dos domos salinos coincidem, respectivamente, com os lineamentos de Maceí́ e Florianópolis, que delimitam a zona de água profunda e estagnada onde ocorreu a precipltaçăo de evaporitos. Embora os próprios evaporitos estejam localmente afetados por falhas normais, pode-se admitir que neste período predominaram condições de relativa quietude tectónica. Segundo VIANA (1980), a seqüência do golfo deve ser de idade aptiana.

d) Seqüência do mar - Podem ser reconhecidas duas subseqüências: a carbonática de plataforma rasa $\theta$ a marinha franca.

A subseqüência carbonática é composta principalmente de calcarenitos e calcilutitos, comumente com texturas oolitica ou pisolitica. Lateralmente, podem passar para arenitos, às vezes grossos, rumo ao continente e peliticos rumo ao oceano. Embora, desde Chuí (RS) até Natal (RN) a subseqüência seja mais ou menos contínua, as idades dos seus topos decrescem do sul para o norte. De fato, os calcários da Bacia de Santos são albianos; no Espirito Santo, albianos a turonianos; em Sergipe/Alagoas, albianos a santonianos e em Pernambuco/Paraiba, albianos a eocênicos. Nesta fase, ocorreram movimentos crustais de baixa intensidade, que se manifestou como subsidência limitada evidenciada por falhas normais próximas às bordas das bacias.

A subseqüência marinha franca é representada por sedimentos detrfticos depositados, contemporaneamente, desde áreas continentais até porções de águas profundas, passando por sistemas deltaico, de plataforma e de talude. Esta subseqüência distribui-se por todas as bacias marginais brasileiras, com idades que variam desde o Albiano ao Recente.

\subsection{Evolução quaternária}

\subsubsection{Generalidades}

Pesquisas realizadas por MARTIN \& SUGUIO (1975, 1976a, 1976b, 1976c, 1978a, 1978b), SUGUIO \& MARTIN (1976a, 1976b, 1978a, 1978b, 1978c, 1982a, 1982b), MARTIN et al. (1979b, 1980b), SUGUIO et al. (1980) no litoral paulista e sul fluminense; por SUGUIO et al. (1982), MARTIN et al. (1984b) na metade sul do litoral capixaba, por BITTENCOURT et al. (1979a, 1979b, 1982a, 1983a, 1983b), MARTIN et al. (1978, 1979a, 1980a, 1980b, 1980c, 1981a, 1981b, 1982, 1983, 1984a), VILASBOAS et al. (1979, 1985), DOMINGUEZ (1982), DOMINGUEZ et al. (1981a, 1981b, 1983), BARBOSA et al. (1986a, 1986b) no litoral, sergipano $\theta$ alagoano permitiram obter um bom conhecimento dos mecanismos de sedimentação atuantes nessas áreas durante o Quaternário. 


\subsubsection{Evolução paleogeográfica}

Para o trecho do litoral brasileiro compreendido entre Macaé (RJ) e Maceió (AL), pode-se admitir a seguinte evolução paleogeográfica durante a formação das planícies costeiras (Fig. 14):

a) $1^{2}$ estádio - Corresponde à sedimentação da Formação Barreiras, provavelmente durante o Plioceno, quando o clima teria sido semi-árido e sujeito a chuvas esporádicas e violentas. Nessas condições, teriam sido formadas amplas faixas de leques aluviais coalescentes em sopés de encostas mais ou menos íngremes (GHIGNONE, 1979) (Fig. 14A). Durante esta época o nível do mar era mais baixo do que o atual e, desta maneira, os sedimentos desta formação recobriram amplamente a plataforma continental atual (BIGARELLA \& ANDRADE, 1964). Os sedimentos da Formação Barreiras estendem-se mais ou menos continuamente desde o Estado do Rio de Janeiro até a foz do Rio Amazonas.

b) $2^{2}$ estádio - A deposição de sedimentos da Formação Barreiras foi interrompida quando o clima passou a ser mais úmido (VILAS-BOAS et al., 1979). A seguir, provavelmente já no Pieistoceno, deve ter ocorrido a Transgressão Antiga ou a Antepenúltima Transgressão (BITTENCOURT et al., 1979a, 1979b), quando a porção externa da Formação Barreiras foi parcialmente erodida formando-se uma linha de falésias (Fig. 14B). Em muitos lugares estas falésias foram erodidas durante a Penúltima Transgressão, tendo sido preservadas apenas nas costas da Bahia, Sergipe e Alagoas.

c) $3^{?}$ estádio - Na fase regressiva subseqüente ao máximo da Antepenúltima Transgressão, o clima retornou a semi-aridez, pelo menos nos estados da Bahia, Sergipe e Alagoas. Este retorno às condições climáticas semelhantes às de deposição da Formação Barreiras levou à sedimentação de novos depósitos continentais, compostos de leques aluviais coalescentes no sopé das falésias da Formação Barreiras (VILAS-BOAS et al., 1985 (Fig. 14C).

d) $4^{2}$ estádio - Corresponde ao máximo da Penúltima Transgressão (123.000 anos A.P.), quando o mar erodiu total ou parcialmente os depósitos continentais do estádio anterior (Fig. 14D). Nesta fase, os baixos cursos dos vales fluviais foram afogados dando origem a estuários e lagunas. Quando a erosão dos depósitos da fase precedente era completa, as ondas retrabalhavam as linhas de falésias originadas no $2^{\ell}$ estádio.

e) $5^{\ell}$ estádio - Durante a regressão que se seguiu à Penúltima Transgressão, foram construídos os terraços pleistocênicos formados por cristas praiais progradantes (Fig. 14E).

f) $6^{\circ}$ estádio - $O$ relevo dissecado, superimposto aos terraços pleistocênicos, bem como aos sedimentos da Formação Barreiras, foi invadido pelo mar durante a última transgressão. Ao afogamento das planícies costeiras pleistocênicas, seguiu-se o desenvolvimento de ilhas-barreiras, que 
A LSEDIMENTAÇÃOO DA FORM. BARREIRAS

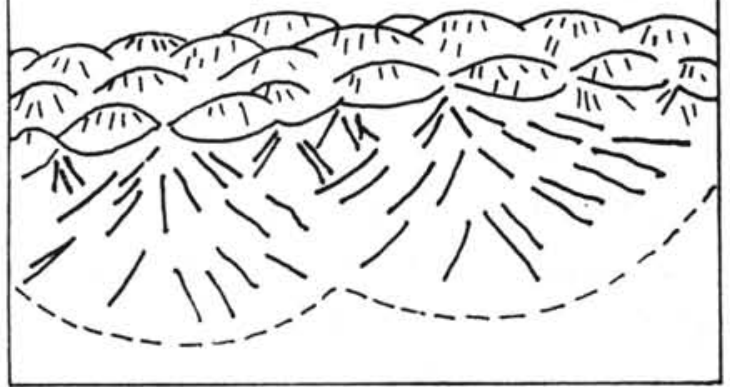

B) MÁXIMO DA TRANSGRESSÃO ANTIGA
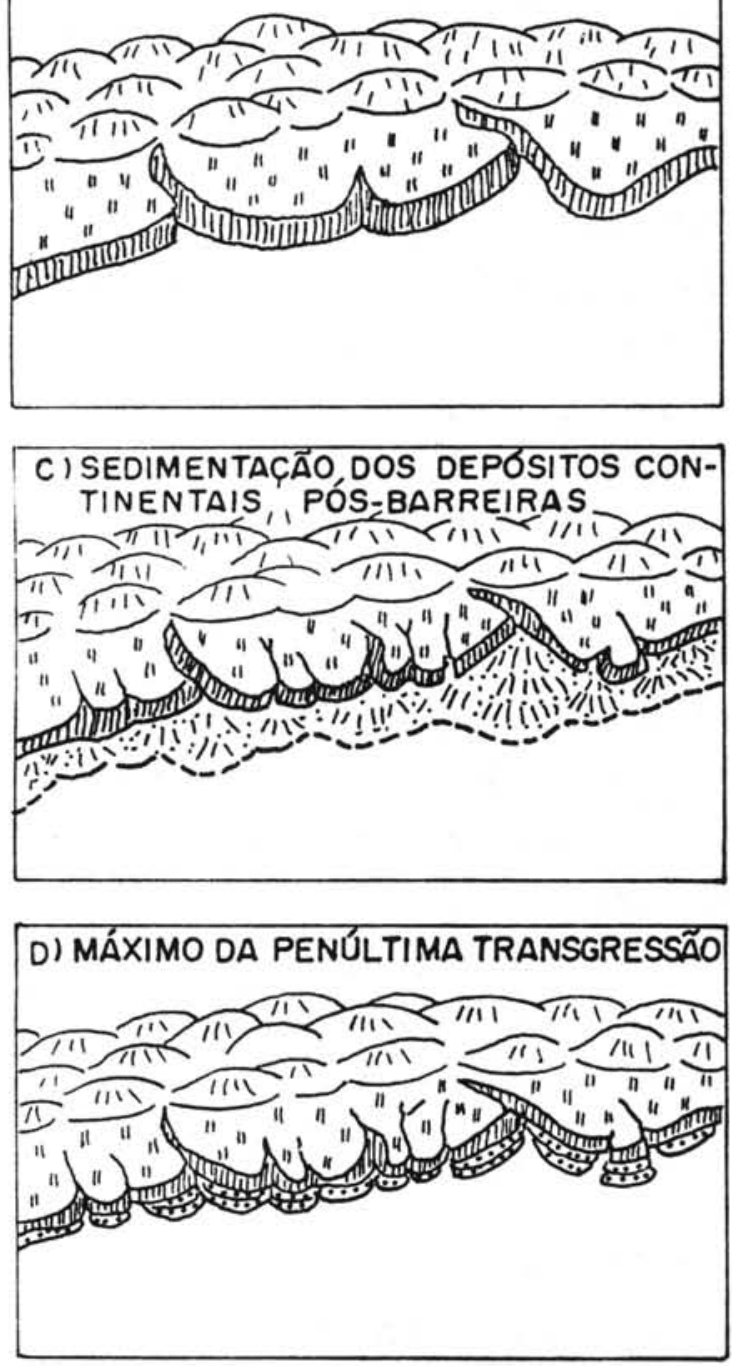

E) FORMAÇÃO DE TERRAÇOS MARINHOS PLEISTOCÊNICOS
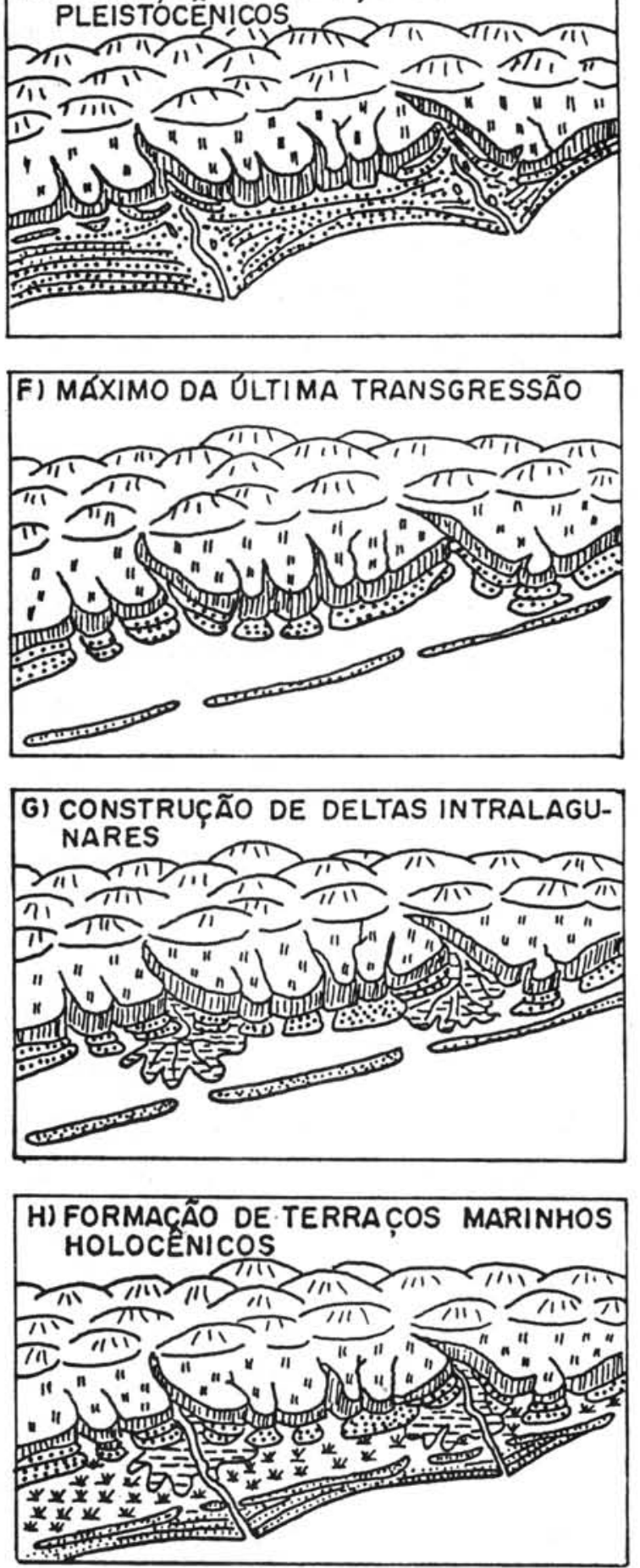

Figura 14 - Estádios evolutivos de sedimentação litorânea, por mecanismos eustáticos e paleoclimáticos, desde o fim do Terciário até hoje. 
isolaram do contato direto com o mar aberto testemunhos de terraços marinhos (Fig. 14F). Atrás dessas ilhas-barreiras instalaram-se lagunas que, em algumas regiões, alcançaram dimensões consideráveis. Datações por radiocarbono de conchas de moluscos e fragmentos de madeira carbonizada provenientes de sedimentos lagunares forneceram idades de até 7.000 anos A.P. sugerindo que as ilhas-barreiras já estavam instaladas antes do pico máximo da última transgressão (5.100 anos A.P.).

g) $7^{\circledR}$ estádio - As lagunas formadas no estádio precedente foram assoreadas por deltas intralagunares, com canais distributários dispostos segundo o padrão pé-de-pássaro (birdfoot). Concomitantemente, a laguna fol passando a lago de água doce, em muitos casos, o assoreamento completo levou ao desenvolvimento de pântanos com turfeiras (Fig. 14G).

h) $8^{\circledR}$ estádio - $O$ abaixamento de nível relativo do mar, que se seguiu ao máximo transgressivo de 5.100 anos A.P., traduziu-se na formação de terraços marinhos a partir das ilhasbarreiras originais (Fig. 14H). O abaixamento do nível do mar transformou as lagunas em lagos ou lagoas, muitas das quais, como as lagoas Bonita e do Zacarias na foz do Rio Doce (ES) e a Lagoa Feia na foz do Rio Paraíba do Sul (RJ) representam antigas paleolagunas de dimensões bem maiores.

As variações de nível relativo do mar, de pequena amplitude e curta duração, subseqüentes aos 5.100 anos A.P. foram muito importantes no desenvolvimento das porçöes mais recentes das planícies costeiras brasileiras. Esses oito estádios evolutivos, na formação das planícies costeiras, constituem o modelo mais completo válido para o trecho entre Macaé (RJ) e Maceió (AL). Dois ou mais desses estádios podem ser omitidos na explicação da história evolutiva de algumas das outras planícies costeiras. 


\section{5. características geológicas e evolução quaternária das planícies COSTEIRAS SITUADAS EM DESEMBOCADURAS FLUVIAIS IMPORTANTES}

\subsection{Generalidades}

As planícies costeiras mais ou menos vastas, formadas por sedimentos quaternários pleistocênicos e holocênicos, constituem uma das feições mais peculiares do trecho aqui considerado do litoral brasileiro. Algumas dessas planícies estão intimamente relacionadas às desembocaduras de cursos fluviais importantes, enquanto que outras não têm este tipo de ligação e, no entanto, ambas passaram por histórias evolutivas semelhantes durante o Quaternário. Neste trabalho, procurar-se-á enfatizar as planícies do primeiro tipo, isto é, com estreita ligação com desembocaduras fluviais, que foram subdivididas em três subtipos:

a) Planícies costeiras com delta intralagunar (rios Doce e Parafba do Sul);

b) Planícies costeiras sem delta intralagunar (rios Jequitinhonha e São Francisco), e

c) Planície costeira de domínio eólico do Rio Parnaíba.

\subsection{O que é um delta?}

\subsubsection{Definição de delta}

O termo delta é bastante antigo, datando de cerca de 400 anos A.C., quando Heródoto o empregou pela primeira vez referindo-se à planície aluvial situada entre os dois distributários principais do Rio Nilo, que exibia grande semelhança com a quarta letra do alfabeto grego.

Em 1832, LYELL introduziu o termo na literatura geológica, definindo-o em 1853 como "um terreno aluvial formado por um rio em sua desembocadura, sem contudo possuir uma forma definida" (MOORE, 1966).

BARRELL (1912) usou o termo para designar "um depósito parcialmente subaéreo construído por um rio de encontro a um corpo permanente de água" (LE BLANC, 1975). Estudando o delta do Rio Mississippi, TROWNBRIDGE (1930) concluiu que o substantivo delta $\Theta$ o adjetivo deltaico deveriam ser usados para designar sedimentos depositados por um rio nas vizinhanças de sua desembocadura. BATES (1953) definiu um delta como "um depósito sedimentar construído por um fluxo de jato dentro de um corpo permanente de água". Esta definição incorporaria também os leques submarinos, que são acumulados nas desembocaduras dos canhões submarinos. Segundo BACOCCOLI (1971), alguns autores utilizaram ainda o termo para designar toda acumulação 
resultante da perda de velocidade de uma corrente aquosa ao penetrar em corpo de água mais volumoso, sejam os depósitos assim formados subaéreos ou subaquáticos.

A medida que novas acumulações costeiras foram sendo descritas e estudadas, a exemplo dos deltas dos rios Colorado (McKEE, 1939; THOMSON, 1968), Ródano (OOMKENS, 1970), Níger (ALEN, 1965) e Orenoco (VAN ANDEL, 1968), o conceito de delta foi sofrendo modificações para poder acomodar novas observações. Desde modo, FISHER et al.(1969) adotaram uma definição mais generalizada segundo a qual um delta seria "um sistema deposicional alimentado por um rio e que resulta na progradação irregular da linha de costa". WRIGHT (1978) enfatiza ainda mais este caráter genérico ao definir um delta como "acumulações costeiras subaquosas e subaéreas construídas a partir de sedimentos trazidos por um rio, adjacentes ou em estreita proximidade com o mesmo, incluindo os depósitos que foram modelados secundariamente pelos diversos agentes da bacia receptora, tais como, ondas, correntes e marés". Por esta definição, um delta pode englobar praticamente todo o espectro de formas de acumulações costeiras, tais como, praias, dunas, planície de marés, pântanos, manguezais, lagunas, ilhas-barreiras, balas, além de depósitos de canal e desembocadura fluvial. Vê-se, portanto, que o conceito de delta é atualmente bastante amplo, sendo utilizado para denominar conjuntos de fácies que têm em comum apenas o fato de constituirem zonas de progradação associadas a um curso fluvial, tendo sido construídas originalmente a partir de sedimentos carreados por este rio.

\subsubsection{Fatores que controlam a formação de um delta}

Para que um delta seja formado é necessário que um rio (corrente aquosa) carregado de sedimentos flua rumo a um corpo permanente de água em relativo repouso. As velocidades das correntes fluviais diminuem a partir da desembocadura para as partes mais distais, de modo que sedimentos sujeitos a velocidade cada vez menores (mais finos) e de forma cada vez menos esféricas e, freqüentemente, mais angulosas são depositadas neste sentido.

Além disso, para que os sedimentos transportados por um rio se acumulem na sua desembocadura e resultem na formação de um delta é necessário que a energia do meio receptor não atinja o nível suficiente para retrabalhá-los e dispersá-los ao longo da costa. A condição sine-qua-non para que ocorra a construção deltaica é que haja um déficit de energia do meio receptor em relação ao aporte sedimentar sendo, desta maneira, os sedimentos empilhados em torno da desembocadura fluvial. A energia do rio, expressa principalmente pela velocidade de suas águas, deverá em geral ser suficiente para manter um ou mais canais escavados através dos próprios sedimentos. Com o prosseguimento dos processos deposicionais o delta progradará para dentro do corpo aquoso. Deste modo, o rio se vê obrigado a avançar através dos seus próprios depósitos, alterando assim o seu 
comportamento, o que gera condiçöes peculiares de sedimentação e conseqüentemente formando corpos sedimentares com diferentes caracteristicas.

Vários são os fatores que condicionam os processos de sedimentação deltaica, os quals mudam bastante, dando em consequêncla, diferentes tipos de deltas. Os deltas quaternários são formados da combinação desses fatores; deste modo, alguns ocorrem ao longo de costas com amplitude de maré desprezivel e energia de onda mínima, enquanto que outros são originados sob condiçöes de grande amplitude de maré ou de intensa attvidade de ondas. Por outro lado, os deltas podem ser construídos sob condições de clima tropical úmido, em regiőes submetidas a intensos processos químicos e biológicos ou em regióes árticas ou de desertos, onde a attvidade biológica e os processos químicos são praticamente nulos. A despelto das dlversidades ambientais, determinadas pela combinação de diferentes fatores que condicionam os processos deltaicos, todos os deltas de progradação ativa apresentam ao menes um atributo em comum, isto é, um rio fornece sedimentos terrigenos à zona costeira e à plataforma interna mais rapidamente do que eles podem ser removidos por processos litorâneos.

COLEMAN \& WRIGHT (1971, 1975) discutem os vários processos costeiros e os seus efeltos e significados na formação de deltas. Segundo estes autores, os fatores mais importantes são: clima, flutuações de descarga fluvial e de carga sedimentar, processos associados à desembocadura fluvial, energia das ondas, regimes de marés, ventos, correntes litorâneas, declvidade da plataforma, tectônica $\theta$ geometria da bacia receptora. Embora todos esses fatores tenham alguma influência, somente poucos processos atuam mais intensamente na formação dos diferentes tipos de deltas. Segundo MORGAN (1970), quatro são os fatores fundamentais que influem na sedimentação deltaica: (a) regime fluvial, (b) processos costeiros, (c) fatores climáticos e (d) comportamento tectônico.

a) Regime filuvial - Em rios com tendência a grandes flutuações sazonais de descarga, os canais não têm tempo suficiente para se ajustarem a um determinado padrão de fluxo, resultando em canais entrelaçados (braided). Por outro lado, quando as variaçōes de descarga anual são pequenas, os canais dispõem de tempo suficiente para se ajustarem a um determinado regime de fluxo, resultando em canais meandrantes. O regime fluvial pode também afetar a granulometria $\theta$ a seleção das partículas. Desta maneira, descargas extremamente erráticas tendem a depositar sedimentos mais grossos e mais pobremente selecionados, enquanto que rios com descargas mais uniformes depositam sedimentos mais finos $\theta$ melhor selecionados. $O$ volume de sedimentos supridos, que também depende das variações de descarga e da composição litológica das rochasmatrizes da bacia de drenagem, é também importante na taxa e no padrão de crescimento dos deltas. Em rios de descarga liquida e carga sedimentar altas e constantes, como no caso do Rio Mississippi, 
comumente são formados corpos arenosos lineares dispostos a fortes ângulos em relação à linha de costa. Por outro lado, em rios com grandes variações na descarga $\Theta$, portanto com grandes flutuações na carga sedimentar, as areias têm oportunidade de ser intensamente retrabalhadas pelos processos marinhos e os corpos arenosos formados tendem a ser paralelos à linha costeira.

b) Processos costeiros

Os processos costeiros compreendem principalmente os efeltos das ondas e marés. O principal efelto das ondas consiste em selecionar e redistribuir os sedimentos fornecidos pelos rios. O grau de influência dos processos fluviais ou das ondas é determinado pela capacidade destes em retrabalhar e redistribuir os sedimentos.

Quando a energla das ondas é muito forte a composiçăo mineralógica das arelas fluviais pode ser drasticamente alterada, sempre tendendo a aumentar o teor de quartzo nos corpos arenosos em detrimento de fragmentos minerais menos estáveis, como o feldspato, resultando em areias limpas $\theta$ bem selecionadas. Em costas de baixa energia de ondas, as areias depositadas são essencialmente produtos de processos fluviais, sendo em geral pobremente selecionados e ricas em argila e mica.

Quando os rios lançam os seus sedimentos em ambientes com grandes amplitudes de marés, estas passam a desempenhar o principal papel na definição das características dos corpos arenosos deltaicos. Nas desembocaduras de rios submetidos a macromarés (amplitudes superiores a $4 \mathrm{~m}$ ) são encontradas correntes bidirecionais fortes que dão origem a cordões arenosos subaquosos cujas características foram descritas por OFF (1963) e WRIGHT et al. (1975). Em geral, os deltas originados em regiões submetidas a macromarés apresentam sedimentos com caracteristicas tipicas de planície de marés e, neste particular, diferem das fácies deltaicas formadas sob condições de micromarés.

Entre os agentes que desempenham um papel importante entre os processos costeiros tem-se as correntes litorâneas (de deriva litorânea), cuja característica principal consiste em formar corpos arenosos orientados subparalela ou paralelamente às correntes. Entre as várias causas geradoras de correntes litorâneas tem-se: propagação de marés, ondas e ventos, gradientes de densidades das águas e principalmente a incidência obliqua das ondas em relação à linha de praia.

c) Fatores climáticos

O tipo de clima determina a intensidade de atuação dos processos físicos, químicos e biológicos que agem em um sistema fluvial. Em bacias hidrográficas situadas em áreas tropicais verifica-se intensa degradação química das rochas, formando-se espesso manto de intemperismo, que é protegido da erosão pela densa cobertura vegetal existente nessas áreas. Os rios transportarão principalmente materiais solúveis e partículas finas em suspensão e poucos sedimentos 
grossos. Este modelo pode ser perturbado pela ação antrópica, como o desmatamento, que acaba induzindo erosão acelerada do manto de intemperismo possibilitando transporte de material mais grosso pelo rio.

Por outro lado, quando o clima da bacia de drenagem é árido, a vegetaçăo é escassa e o regime fluvial é irregular. Nessas condições os canais tornam-se instáveis desenvolvendose freqüentemente canais entrelaçados (braided) pelos quais são transportados sedimentos apresentando excesso de carga de fundo em relação a de suspensão.

d) Comportamento tectônico

A geometria dos litossomas em seqüências sedimentares deltaicas é amplamente controlada pelo comportamento tectônico do sítio deposicional. Rápida subsidência dá origem a espessos pacotes de areias deltaicas, enquanto que lenta subsidência ou relativa estabilidade resultam em delgadas seqüências deltaicas.

\subsubsection{Classificação de deltas}

Diferentes critérios têm sido usados na classificação de deltas. Considerando-se a natureza da bacia receptora, LYEU (1832) classificou os deltas em continentais e marinhos. Algumas classificações baseiam-se na configuração em planta das planícies deltaicas emersas, reconhecendose os seguintes tipos: lobado, alongado, em cúspide e em franja (FISHER, 1969). Outros pesquisadores têm caracterizado os deltas em comparação aos mais detalhadamente estudados, denominando-os assim, por exemplo de tipo Ródano, tipo Mississippi, tipo Níger, etc. BATES (1953), baseado nos contrastes de densidade entre as águas do afluente fluvial principal e do corpo líquido receptor, reconheceu três tipos fundamentais (Fig. 15):

a) Deltas homopicnais - A densidade do meio transportador (rio) é praticamente igual a do meio receptor (lago). A sedimentação progride nas três dimensões segundo o delta do tipo lacustre de GILBERT (1889).

b) Deltas hiperpicnais - A densidade do meio transportador é maior do que a do meio receptor e, deste modo, os sedimentos são carreados ao longo do substrato por meio de correntes de turbidez. Esses "deltas" formar-se-fam ao sopé dos taludes continentais nas desembocaduras de canhões submarinos.

c) Deltas hipopicnais - A densidade do meio transportador é menor do que a do meio receptor $\theta$, desta maneira, os sedimentos movem-se sobre a superfície do meio mais denso. Esta situação seria mais característica dos deltas originados por rios que deságuam em mares e oceanos.

MOORE (1966), baseado em trabalhos de LYEL (1832) e de BATES (1953), estabeleceu quatro tipos principais de deltas: a) deltas de canhões submarinos (fluxo hiperpicnal em 
forma de jato plano), b) deltas lacustres (fluxo homopicnal em forma de jato axial), c) deltas mediterrâneos (fluxo homopicnal em forma de jato plano) e d) deltas oceânicos (construídos em amblentes de macromarés).

SCOTT \& FISHER (1969) adotaram, especificamente para os deltas marinhos, uma classificação baseada em conceltos genéticos (natureza $\theta$ intensidade dos agentes oceânicos em jogo) e na distribuição das fácies nas porções subaéreas do delta (Fig. 16). Deste modo, estabeleceram duas grandes subdlvisőes: deltas construtlvos (com predominâncla de fácles fluviais) $\theta$ deltas destrutivos (com predominância de fácies marinhas). O primeiro grupo é subdividido em deltas lobados $\theta$ alongados $\theta$ o segundo é subdividido, conforme a predominâncla das ondas ou das marés, em tipo em cúspide (dominado por ondas) e tipo em franja (dominado por marés).

GALLOWAY (1975) apresentou uma classificação, modificada de SCOTT \& FISHER (op.cit.), baseada na ação recíproca dos processos marinhos e fluviais e no papel desempenhado por estes na construção deltaica, propondo grande variedade de tipos de deltas, que podem ser agrupados em um diagrama triangular (Fig. 17), segundo três membros extremos: a) deltas de domínio fluvial, b) deltas dominados por ondas e c) deltas dominados por marés.

COLEMAN \& WRIGHT (1975), baseados na geometria dos corpos arenosos encontrados nos depósitos deltaicos, reconheceram pelo menos seis diferentes tipos básicos de deltas, que não receberam designação formal por parte desses autores.

Em suma, o delta passa a ser o resultado exclusivo da athidade fluvial (velocidade de fluxo, densidade do afluente, carga sedimentar, etc.) somente quando a bacia receptora se caracteriza por baixos niveis de energia (atlvidade desperezivel de ondas e marés). Em contrapartida, quando os niveis de energia da bacia receptora são elevados, a acumulação deltaica resulta da sedimentação marinha através de ondas e marés, que retrabalham os sedimentos fluviais e constroem o arcabouço deltaico.

\subsubsection{Ambientes e fácies de sedimentação}

Indistintamente, todos os deltas compreendem uma porção subaérea $\theta$ outra subaquosa. A parte subaérea abrange a região da planície deltaica situada acima de maré baixa $\theta$ a subaquosa compreende a permanentemente submersa. Esta última parte forma o substrato sobre o qual se processa a progradação da parte subaérea. Por outro lado, na porção subaérea da planície deltaica podem ser reconhecidas a superior e a inferior, separadas pelo limite de influência das marés.

Segundo READING (1979), os deltas apresentam duas províncias fundamentais: planície deltaica e frente deltaica. 


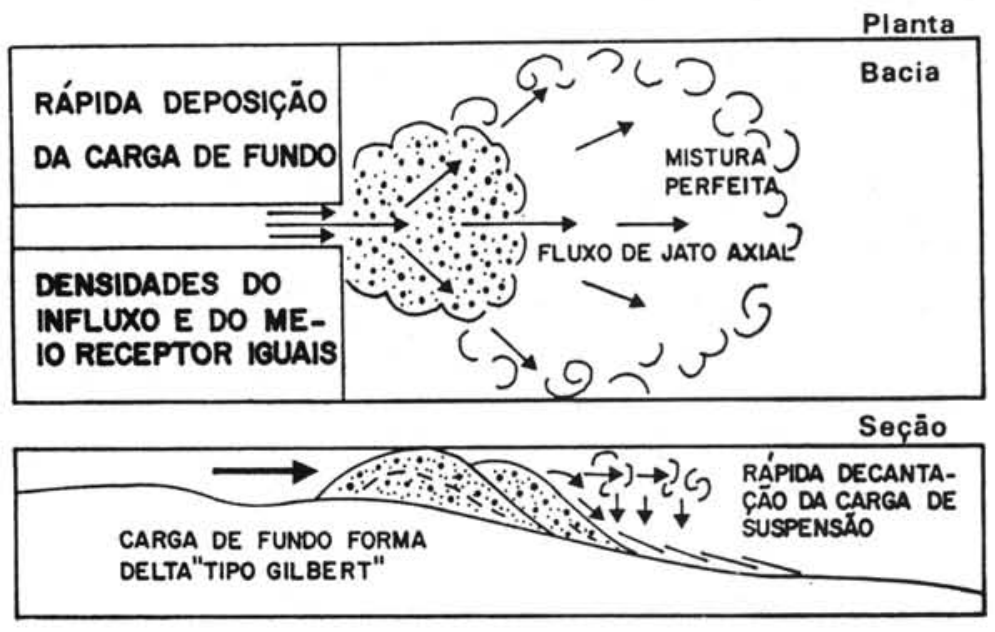

FLUXO HOMOPICNAL

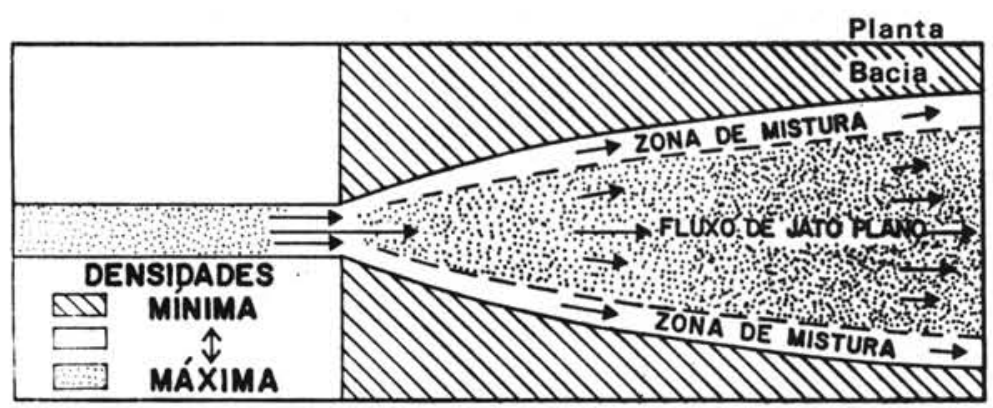

FLUXO HIPERPICNAL

Seçāo
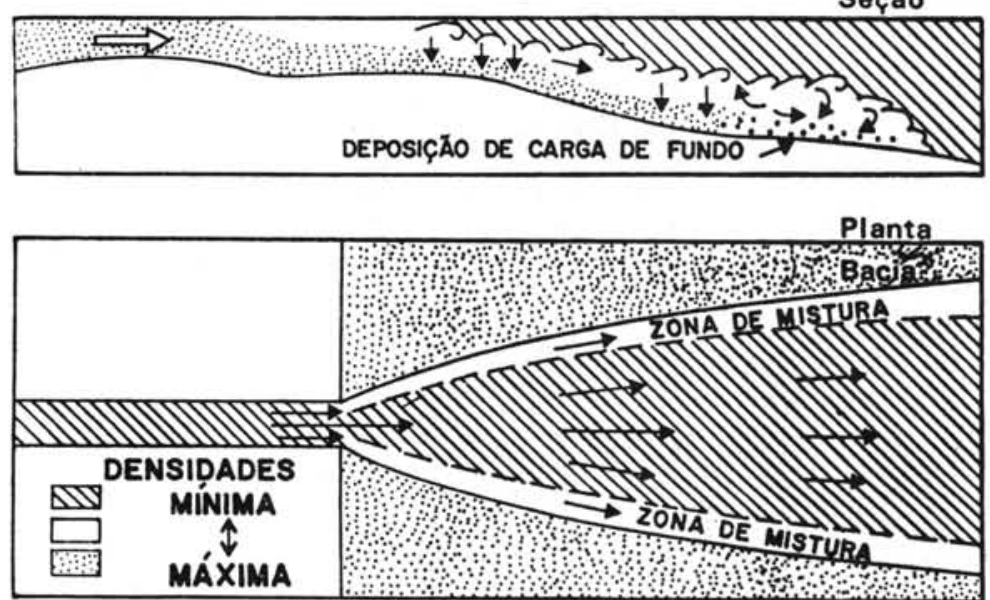

FLUXO HIPOPICNAL

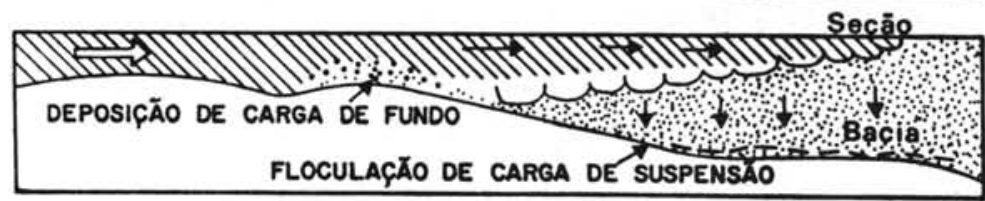

Figura 15 - Modos de interação entre águas fluviais de influxo e de bacias receptoras em função de suas densidades relativas (BATES, 1953). 


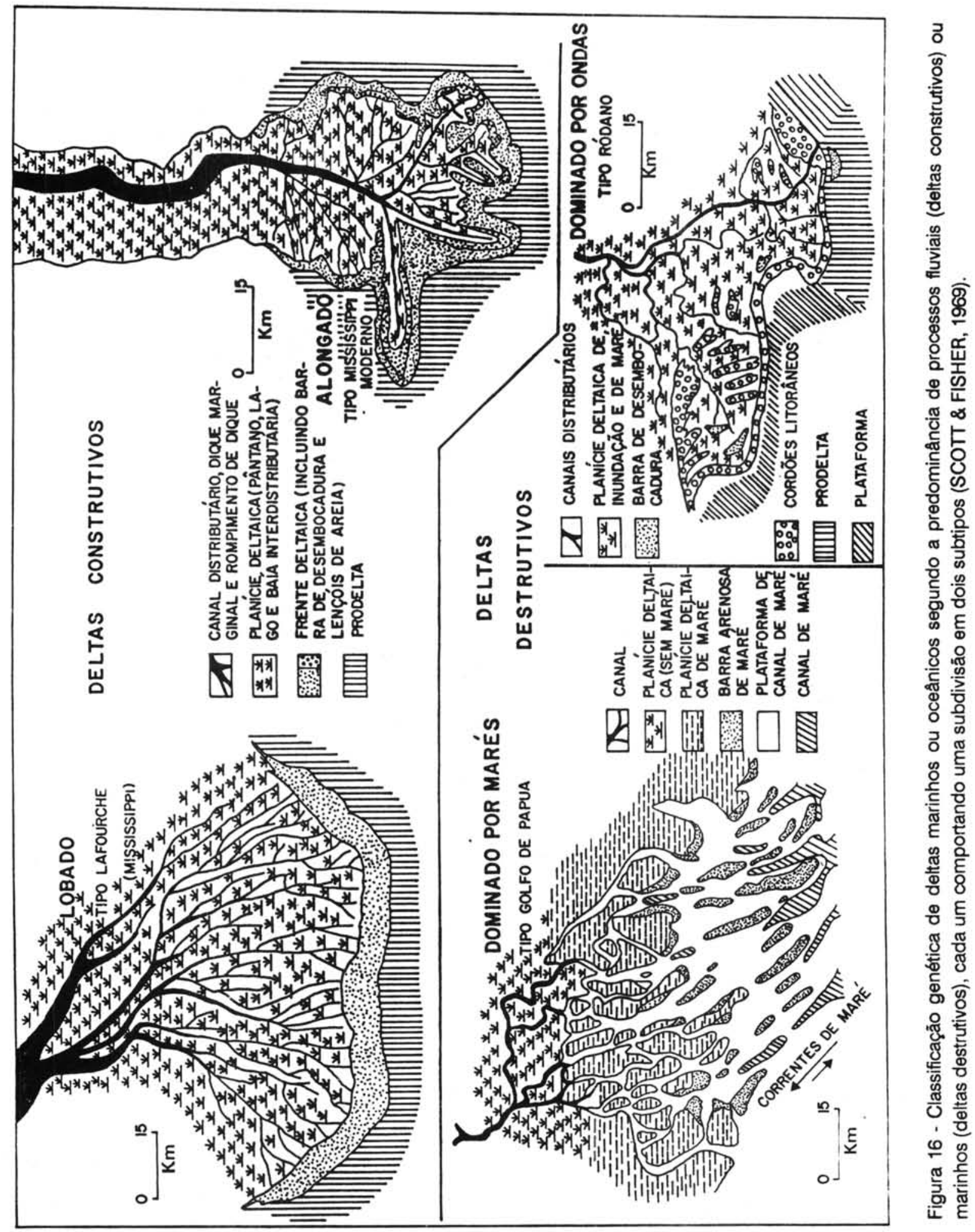




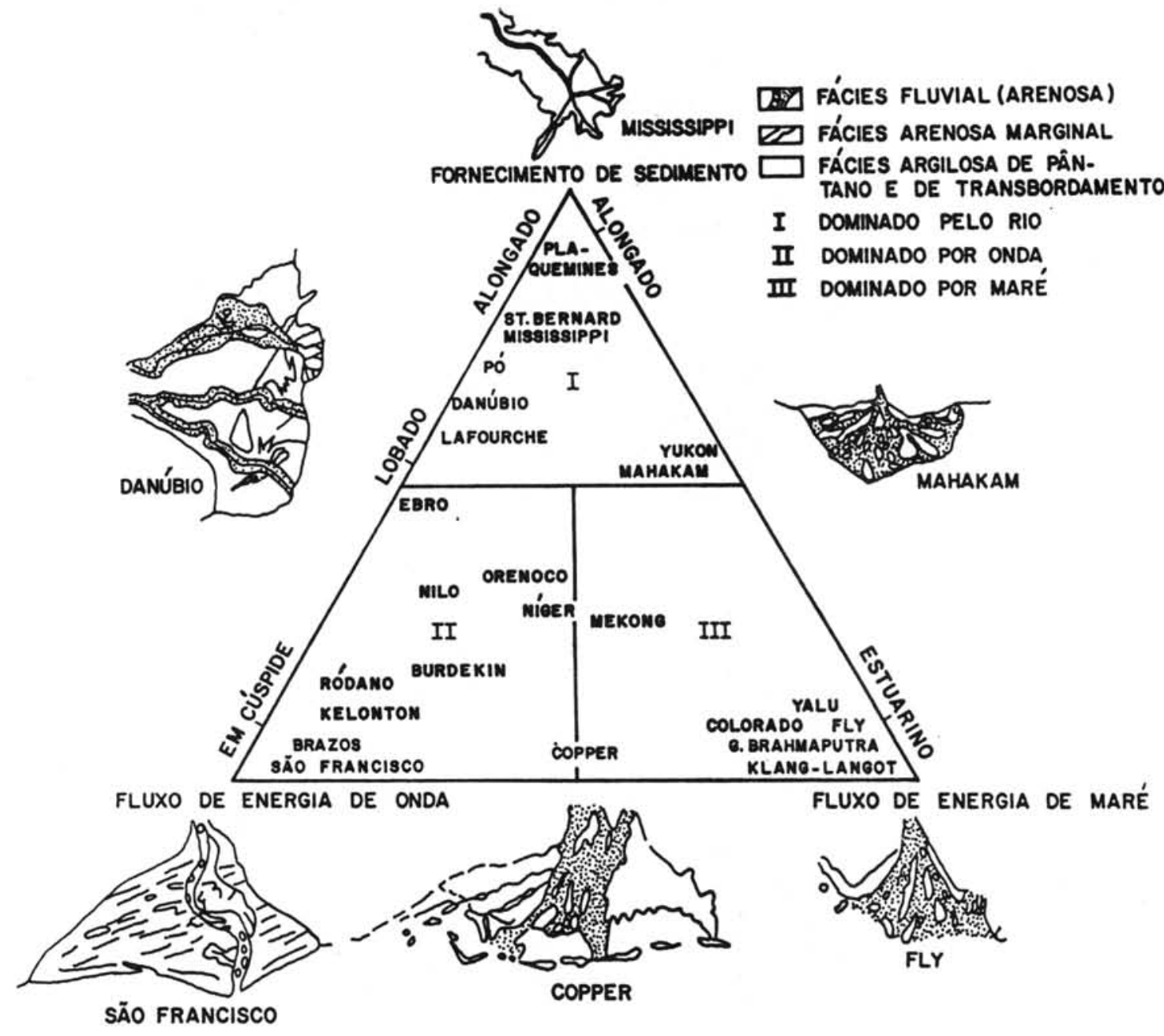

NOTA: O MAPA DO DELTA DO RIO SÃO FRANCISCO AQUI APRESENTADO É GROSSEIRAMENTE FALSO.

Figura 17 - Classificação genética de deltas marinhos ou oceânicos, análoga à anterior, baseada nas intensidades de fornecimento de sedimentos e de fluxo de energia de onda ou de maré (GALLOWAY, 1975).

\subsubsection{Planicie deltaica}

Área plana onde se encontram os canals distributários attvos ou abandonados, separados entre si por ambientes de águas rasas e superficies subaéreas ou parcialmente submersas. Grande número de canais distributários drena esta área, dividindo a carga total do sistema fluvial e alimentando a frente deltaica. Entre os canais são encontrados diversos tipos de amblentes de águas rasas, tais como, balas, planícies de marés, pântanos salinos e manguezais, que constituem ambientes extremamente sensiveis ao tipo de clima dominante na área. Em regiões de clima úmido e quente 
(tropical e subtropical), as planícies deltaicas podem exibir vegetação luxuriante, enquanto que em condições de clima seco (árido ou semi-árido) a vegetação torna-se escassa, sendo caracterizadas por depósitos de calcretes ou de evaporitos (halita, gipsita, etc.). Entre as planícies deltaicas vale a pena destacar dois tipos extremos: a) dominada por processos fluviais e b) dominada por marés.

a) Dominada por processos fluviais

Este tipo de planície pode ser caracterizado por cristas praiais que podem passar gradativamente a jusante para planícies de marés ou diretamente para frentes deltaicas. Os canais distributários apresentam fluxo unidirecional com flutuações periódicas e as seqüências de fácies sedimentares são semelhantes às de canais de sistemas fluviais comuns. As planícies interdistributárias são ocupadas por lagos rasos ou pântanos. Durante as enchentes dos rios as águas se extravasam dos canais e dão origem a feições como de diques marginais e depósitos de rompimento de diques marginais. $\mathrm{O}$ excesso de água dá origem a amplas áreas inundadas, que favorecem o crescimento da vegetação ou a precipitação de evaporitos, dependendo das condições climáticas.

b) Dominada por marés

A planície deltaica dominada por maré ocorre em regiões cujas amplitudes são de moderadas a altas. Neste caso, as correntes de marés penetram pelos canais distributários durannte as marés enchentes cobrindo os bancos dos canais e invadindo as áreas interdistributárias adjacentes. As águas são estocadas temporariamente durante o período de estofa da maré para serem, em seguida, liberadas durante as marés vazantes. O efeito das correntes assim geradas é mais importante nos cursos inferiores dos distributários, enquanto que as áreas interdistributárias assumem feições de planícies de marés. Os canais distributários exibem baixa sinuosidade, forma afunilada e alta razão largura/profundidade. As áreas interdistributárias apresentam várias lagunas, pequenos canais de marés e planícies de marés que, durante o ciclo das marés, são inicialmente inundadas e depois expostas, quando então são submetidas ao efeito do clima reinante no local.

\subsubsection{Frente deltaica}

Formada pela área da bacia receptora que recebe os distributários deltaicos mais ou menos carregados de sedimentos, os quais são dispersados após interagirem em maior ou menor grau com os processos dinâmicos atuantes no local. Podemos distinguir quatro tipos: a) dominada por processos fluviais, b) dominada por ondas, c) dominada por processos fluviais e ondas, d) dominada por marés e e) dominada por processos fluviais, ondas e marés.

a) Dominada por processos fluviais

Este tipo acha-se muito bem representado no Delta do Mississippi, onde os sedimentos correspondentes contém $98 \%$ de lama e $2 \%$ de areia fina e, sendo tipicamente fluviais, é mínima a interferência dos processos atuantes na bacia receptora. 
Entre as fácles representativas de progradação de canais distributários neste tipo de frente deltaica têm-se as planícies de lama e os diápiros de lama. As planícies de lama são depósitos de arglla $\theta$ silte fino multo ricos em matérla orgânica. Elas formam-se onde o suprimento argiloso fluvial sobrepuja a capacidade dispersora dos agentes costeiros. Esses depósitos distinguemse das argilas prodeltaicas, propriamente ditas, por serem mais ricos em matéria orgânica do que aquelas. Por outro lado, distinguem-se dos depósitos de pântano, com os quals freqüentemente se associam, pela ausência de turfa que é muito comum em depósitos paludiais. Os sedimentos mais grossos são fornecidos multo mais escassamente e podem formar depósitos pralais isolados no meio das planicies de lama formando, desta maneira, os depósitos de chêniers.

\section{b) Dominada por ondas}

Neste tipo as ondas são capazes de redistribuir a maior parte dos sedimentos carreados por um rio. A linha de costa é regular e avança mar adentro em forma de cúspide próximo às desembocaduras dos distributários.

A porção submersa apresenta declividade muito acentuada e a progradação é relativamente lenta em confronto com os outros tipos. Sistemas de cristas praiais abandonados, situados por detrás da frente deltaica attva, săo separados entre si por discordâncias erosivas ligadas à migração de canais distributários.

Este tipo de frente deltaica pode apresentar semelhanças com o tipo dominado por processos fluviais e ondas, principalmente no que concerne a sua sequência vertical, porém pequenas diferenças permitem a distinção entre ambos. Nos deltas dominados por ondas, todas as estruturas são produzidas pela ação de ondas e, desta maneira, a unidade basal de granulometria fina é em geral pouco espessa em função da eliminação da maior parte dos sedimentos finos através da lavagem pelas ondas. Como a progradação envolve toda a frente deltaica, não sendo concentrada em trechos isolados, o corpo arenoso resultante é paralelo à costa e tem a forma de lençol, enquanto que nos deltas dominados por processos fluviais e ondas a forma é lobada. Além disso, como as fácies sedimentares de um delta dominado por ondas são idênticas às fácies de sistemas não deltaicos relacionados a cristas praiais progradantes, a distinção entre as duas deve ser fundamentada em critérios mais regionais.

c) Dominada por processos fluviais e ondas

Este tipo de frente deltaica é caracterizado por uma linha de costa suavemente arqueada ou em cúspide. Protuberâncias localizadas nas proximidades da desembocadura represetam complexos sedimentares formados por barras de desembocadura flanqueadas por cristas praiais arenosas. Essas feições sugerem que as ondas são ainda capazes de redlstribuir parcialmente os sedimentos fornecidos pelo rio. 


\section{d) Dominada por marés}

A frente deltaica dominada por marés é encontrada em áreas de macromarés. A linha de costa $\theta$ as desembocaduras dos canais distributários apresentam um padráo pouco definido $\theta$ constituido por bancos arenosos submersos, canais e ihas, que podem estender-se por considerável distancia costa afora.

e) Dominada por processos fluviais, ondas e marés

Este tipo de frente deltaica é mais típico de área caracterizada por marés de amplitude média (2 a $4 \mathrm{~m}$ ). Os efeitos das marés são restritos às desembocaduras fluviais, enquanto que as ondas atuam em outras partes da frente deltaica $\theta$ a linha de costa é caracterizada por praias ou chêniers separados por canais distributários e desembocaduras. Na plataforma interna os contornos batiméticos e os corpos sedimentares tendem a ser paralelos à costa, podendo haver pequenas protuberâncias nas proximidades das desembocaduras.

Pode parecer estranho que todos os modelos revistos aqui por nós tenham sido estabelecidos considerando o nivel marinho como constante, pois nós já vimos que no decorrer dos últimos 7.000 anos as variações não foram homogêneas, por exemplo, nos Estados Unidos e no Brasil. Por outro lado, é fácil compreender que, conforme o nivel relativo do mar tenha estado em elevação ou em abalxamento a dinâmica litorânea tenha sido diferente.

\subsection{Planicies costeiras com delta intralagunar}

\subsubsection{Planicie costeira do Rio Doce (ES)}

\subsubsection{Aspectos gerais}

Esta planicie abrange uma superfície de aproximadamente $2.500 \mathrm{~km}^{2}$, com comprimento na direção N-S de 130 km e uma largura máxima de 38 km (Fig. 18).

O clima desta parte do litoral brasileiro pode ser enquadrado no tipo pseudoequatorial (W da classificação de KÖPPEN, 1948). A região encontra-se em uma zona caracterizada por chuvas tropicais de verão com estação seca durante o outono e inverno porém, mesmo a estação seca pode ser perturbada por precipitaçōes frontais de descargas devidas ao ar polar. Disso resulta, conforme ANDRADE (1964), um regime pluviométrico semelhante ao equatorial com chuvas bem distribuldas através do ano, fato que alís reflete-se na vegetação do Balxo Vale do Rio Doce, que lembra a floresta amazônica. A temperatura média anual é de $22^{\circ} \mathrm{C}$, ficando a média das máximas entre $28^{\circ}$ e $30^{\circ} \mathrm{C}$, enquanto que as mínimas atingem valores inferiores a $15^{\circ} \mathrm{C}$.

Segundo medidas realizadas entre fevereiro de 1972 e janeiro de 1973, pelo Centro Tecnológico de Hidráulica da Universidade de São Paulo (CTH/USP), os ventos dominantes na área 


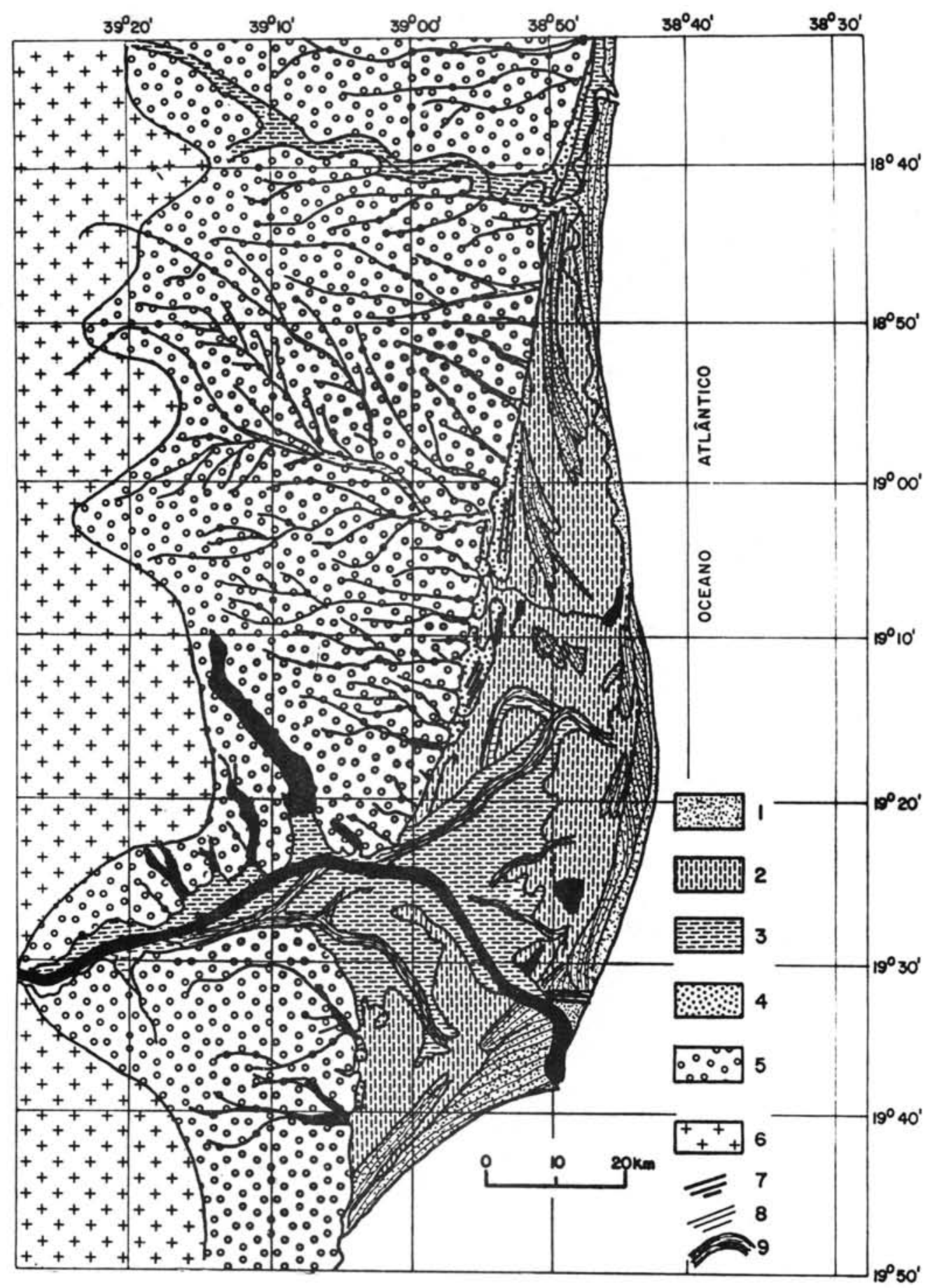

Figura 18 - Mapa geológico esquemático da planície costeira do Rio Doce (ES): (1) terraço marinho holocênico, (2) sedimentos lagunares, (3) sedimentos fluviais (delta intralagunar), (4) terraço marinho pleistocênico, (5) sedimentos continentais terciários (Formação Barreiras), (6) embasamento cristalino pré-cambriano, (7) alinhamentos de cristas praiais pleistocênicas, (78) alinhamentos de cristas praiais holocênicas e (9) paleocanais
fluviais. 
provém dos quadrantes NE e SE. Os mais fortes são originários do SE, atingindo 4 a 5 graus na escala Beaufort. Os de NE-ENE devem ser atribuídos aos ventos alísios desviados, que sopram na maior parte do ano, enquanto que os de SE estão relacionados às frentes frias que chegam periodicamente à costa capixaba, principalmente durante os meses de inverno. De fato, as condições normais de circulação em outono e inverno, sobre a América do Sul, são caracterizadas pela passagem na média e alta troposfera de sucessivas ondas meridianas e na superfície de sistemas frontais correspondentes (Fig. 19A). No mar, os últimos são acompanhados por ventos e ondas do setor sul.
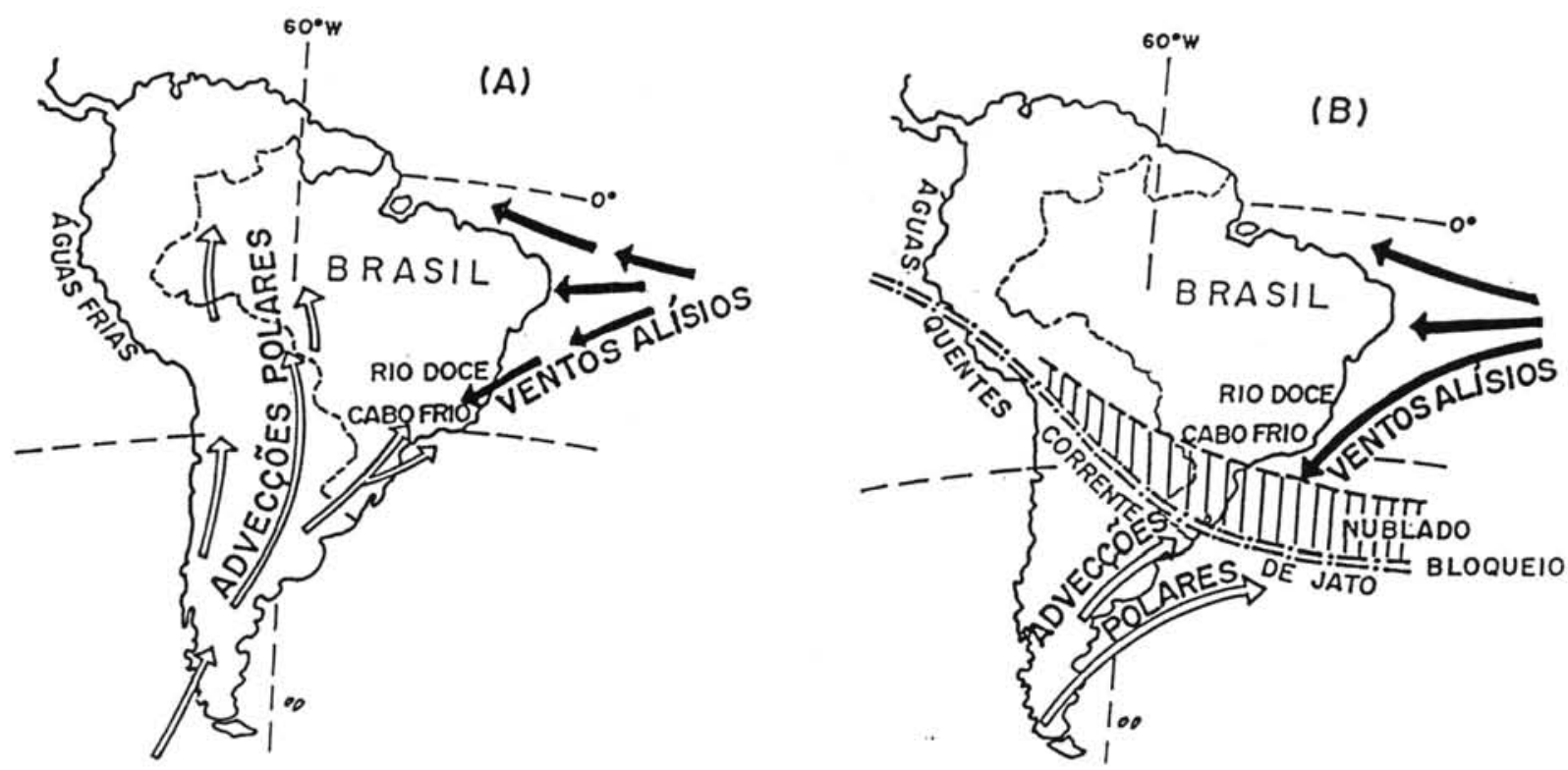

Figura 19 - Esquemas de circulação atmosférica sobre a América do Sul sob: (A) condiçōes normais e (B) durante fenômenos do tipo "EL Niño", como em 1983, regida por ventos alísios e advecçóes polares.

As informações disponiveis sobre as ondas são bastante incompletas, porém já são suficientes para mostrar que elas provém de dois setores: ENE e SSE, sendo as últimas as mais fortes (BANDEIRA JÚNIOR et al., 1975). É evidente que essas ondas são geradas por dois sistemas de ventos existentes na região (Fig. 20A). As ondas do setor sul, embora sejam menos freqüentes, são muito mais efetivas do que as do setor NE pois são muito mais fortes. Conseqüentemente, a resultante final do transporte litorâneo de sedimentos será dirigida de sul para o norte. Entretanto, este modelo pode ser perturbado por anomalias de temperatura de superfície do Oceano Pacffico, ao norte de Peru, 
conhecidas sob a designação de Fenômeno El Niño. Em período de forte atividade deste fenômeno, a passagem das ondas meridianas da média $\theta$ alta troposfera é bloqueada pela presença de uma forte $\theta$ permanente corrente de jato subtropical. Esta corrente estende-se do Pacffico ao sul do Brasil, passando pelo norte do Chile e da Argentina (Fig. 19B). Em período de bloquelo, as zonas frontais permanecem por longos períodos de tempo no S e SE do Brasil, que então é caracterizado por alta pluviosidade e, por outro lado, onde as advecções polares constituem praticamente as únicas fontes de chuvas, como no Nordeste Brasileiro, ocorre um recrudescimento da seca.
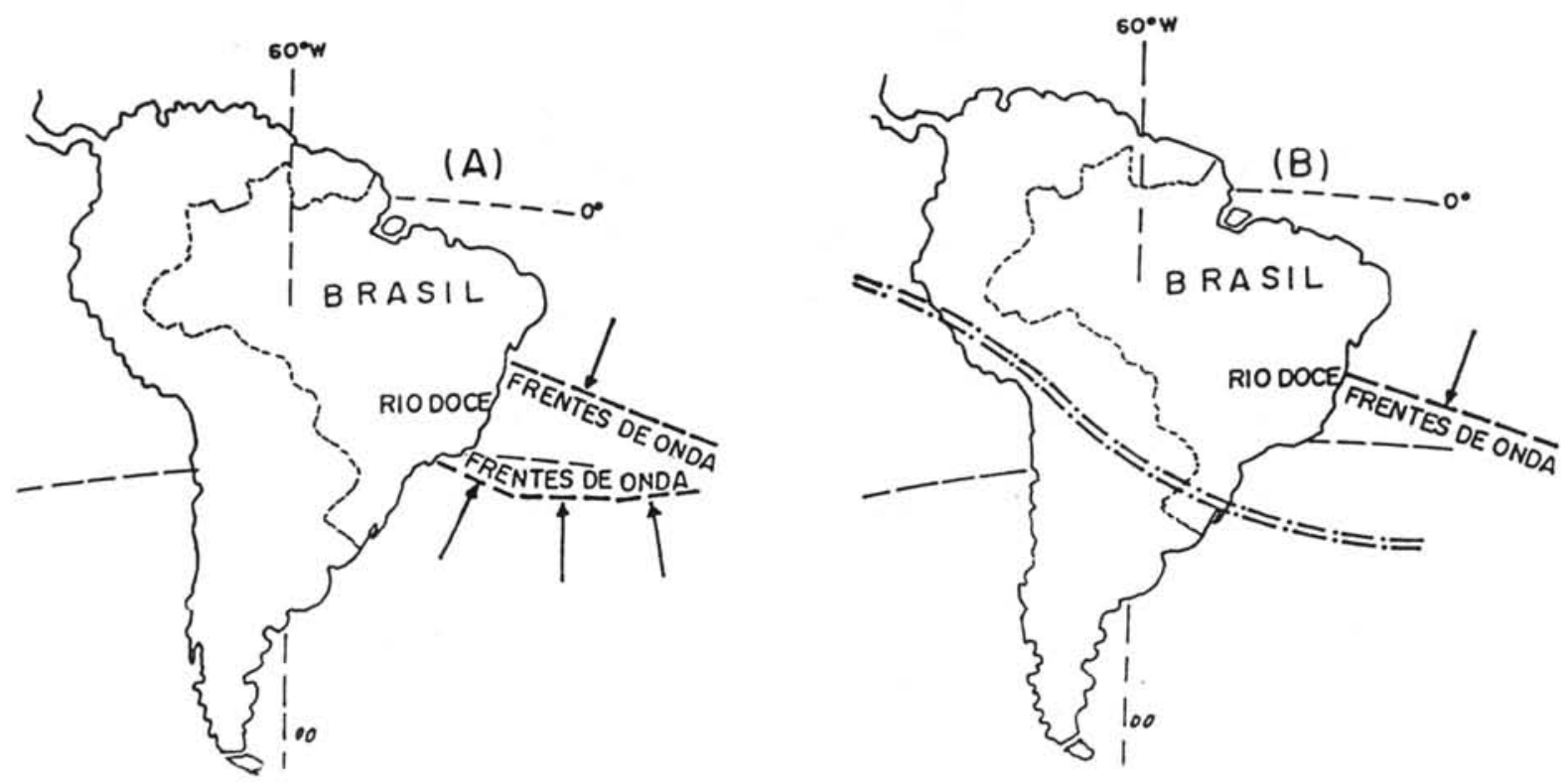

Figura 20 - Esquemas de sentidos de incidência das frentes de onda na área da planície costeira do Rio Doce (ES) sob: (A) condiçōes normais (maior eficiência das ondas do Setor Sul) e (B) condiçōes do tipo El Niño (ação das ondas do Setor NE, por eliminação do efeito das ondas do Setor Sul).

Paralelamente, nos períodos de atuação do Fenômeno El Niño, as ondas do setor sul, geradas pelas advecções polares, não atingem a região da desembocadura do Rio Doce. Nesta situação, as ondas do setor NE tornam-se mais eficazes provocando o transporte litorâneo de sedimentos do norte para o sul (Fig. 20B).

O Rio Doce é o principal rio da área com cerca de $750 \mathrm{~km}$ de extensão, formando uma bacia hidrográfica de aproximadamente $83.000 \mathrm{~km}^{2}$. Em Linhares (ES), próximo à foz, o regime deste rio deve ser considerado tropical com um período de altos débitos devidos às chuvas de verão $e$ outro de baixos débitos nos meses de inverno. Porém, em Colatina e Linhares, mesmo durante os períodos de estiagem, o rio conserva descargas relativamente altas em virtude das precipitações 
ligadas às advecções polares. Em 1972, foi verificada a descarga diária máxima de $1.975 \mathrm{~m}^{3} / \mathrm{s}$ em 4 de março e a mínima de $426 \mathrm{~m}^{3} / \mathrm{s}$ ocorreu em 2 de outubro. A médla mensal máxima fol de 1.121 $\mathrm{m}^{3} / \mathrm{s}$ em março e a minima de $479 \mathrm{~m}^{3} / \mathrm{s}$ em outubro (BANDEIRA JÚNIOR et al., op.cit.).

As concentrações de materiais sólidos em suspensão săo muito varíveis, tornando-se mais altas durante as enchentes e mais balxas nas estiagens. A carga anual de sólidos em suspensão transportada pelo Rio Doce, segundo medidas do CTH/USP em 1972, foi de 4.000 .000 de toneladas (BANDEIRA JÚNIOR et al., op.cit.). Admitindo-se que a carga de material transportado por arrasto (carga de fundo) corresponde a $20 \%$ da carga em suspensão, conforme tem sido normalmente admitida nesses cálculos, tem-se $\mathbf{8 0 0 . 0 0 0}$ toneladas por ano. Esta cifra deve ser encarada como modesta, embora talvez seja pouco representativa por ter sido obtida através de apenas um ano de medições.

\subsubsection{Geomorfologia}

Tanto as feições fisiográficas, quanto os padrões da rede de drenagem, permitem distinguir três províncias geomorfológicas bem distintas: a) Região Serrana, b) Tabuleiros Terciários $\theta$ c) Planície Quaternária (Fig. 18).

a) Região Serrana - Ela é formada por terras altas e coincide com a área de ocorrência de rochas cristalinas pré-cambrianas. Os rios formam vales com perfis encaixados em forma de "V", compondo uma rede densa de drenagem de natureza dendrtica. São encontradas muitas ravinas mortas, morfologicamente semelhantes a voçorocas, hoje cobertas pela vegetação, sugerindo a existência de uma fase de desequillbrio morfogenético, hojejá superada.

b) Tabuleiros Terciários - Esta superfície é plana e suavemente inclinada para o mar $(1,2 \mathrm{~m} / \mathrm{km})$, achando-se esculpida sobre os sedimentos da Formação Barreiras. A drenagem da área é feita por rios que definem padrões subparalelos e angulares. O padrão subparalelo é unidirecional $\Theta$ definido pelo gradiente inicial da superfície, enquanto que o angular corresponde à imposição de zonas de fraturamentos. A maioria dos vales apresenta-se com fundos chatos e colmatados por sedimentos quaternários, por onde serpenteiam rios ou riachos, em geral muito reduzidos em relação à largura da planície aluvial. Parece existirem duas gerações de vales, a dos vales conseqüentes que escavaram mais profundamente a Formação Barreiras, mostrando as planícies colmatadas e limitadas por encostas íngremes e a dos vales resseqüentes que se instalaram sobre a superfície pós-Barreiras e não se acham encaixados. Não foram encontrados terraços fluviais nos vales com fundos colmatados.

A superfície dos Tabuleiros Terciários passa para a Planície Quaternária através de uma pequena escarpa, como acontece na regiōes de Linhares e São Mateus, ou de modo transicional e quase imperceptível, como na reglão da Lagoa do Durão e outras lagoas existentes entre Linhares e São Mateus. Essas lagoas, em sua maioria formadas em conseqüência da barragem de cursos fluviais 
por sedimentos marinhos ou do próprio Rio Doce, chegam a ser muito grandes, como a Lagoa do Juparanã com cerca de $40 \mathrm{~km}$ de comprimento. Por outro lado, os fundos dessas lagoas se encontram freqüentemente abaixo do nivel do mar atual, como acontece na lagoa das Palmas (- $27 \mathrm{~m}$ ), Lagoa Nova $(-16 \mathrm{~m})$ e Lagoa das Palminhas $(-8 \mathrm{~m})$. As lagoas do Juparană $\Theta$ Juparană Mirim são as duas maiores $\theta$ apresentam os fundos mais ou menos assoreados $\theta$ aproximadamente horizontais, em geral acima do nivel do mar, mas também exibem locais com até $-8,2 \mathrm{~m}$ e $-31 \mathrm{~m}$, respectivamente (BANDEIRA JÚNIOR et al., op.cit.). Essas profundidades representam as fases em que o nivel relativo do mar estava multo mais abaixo do atual, quando o Rio Doce $\theta$ os seus afluentes escavaram profundamente os seus vales em sedimentos da Formação Barreiras.

c) Planície Quaternária - Esta área estende-se em forma de crescente assimétrico, convexo para o lado do mar, com a maior largura na direção E-W verificada pouco ao norte do atual éxo do Rio Doce. Para o sul a largura da planície costeira decresce bruscamente, enquanto que para o norte o estreitamento é gradual e estende-se por $110 \mathrm{~km}$ até além de Conceição da Barra. Na Planície Quatemária são também freqüentemente encontradas lagoas, que parecem ter resultado da barragem de antigas drenagens por cristas praiais ou representam feições vestigiais de uma paleolaguna de maiores dimensões.

Seções sísmicas e perfurações realizadas pela PETROBRÁs na planície costeira do Rio Doce revelaram um tectonismo de falhas que afetaram profundamente as unidades litoestratigráficas do Cretáceo da Bacia do Espirito Santo, em contraste com a calma tectónica reinante a partir do Terciário (BANDEIRA JÚNIOR et al., op.cit.).

\subsubsection{Dep6sitos Quaternários (Fig. 18)}

a) Terraços arenosos marinhos - Mesmo em mapa geológico simplificado, como a Figura 18, já se pode distinguir duas gerações de depósitos arenosos marinhos. Entre os argumentos que permitem afirmar que se tratam de depósitos diferentes tem-se os seguintes:

- posições relativas dos depósitos; os primeiros em posição interna adjacente à Formação Barreiras e os últimos próximos à linha de costa atual:

- idades ao radiocarbono superiores ao seu alcance normal (30.000 anos A.P.) para os depósitos internos e inferiores a 7.000 anos para os externos.

- depósitos internos são caracterizados pela ausência de conchas, coloração em geral amarelada a acastanhada e malor coesão; em contraposição, os depósitos externos exibem freqüentemente restos de conchas, coloração mais clara e menor coesão.

- em fotografias aéreas pode-se notar maiores espaços entre a cristas praiais sendo, além disso, mais dissipadas nos depósitos internos, enquanto que os alinhamentos são mais nitidos e menos distanciados nos depósitos externos. 
Terraços marinhos pleistocênicos - Correspondem aos depósitos internos, acima referidos, que se caracterizam superficialmente pela cor branca mas em profundidade apresentam comumente cores acastanhadas ou pretas. As cores escuras podem ser atribuldas à presença de matéria orgânica epigenética, que está impregnando os grãos minerais.

A origem em ambiente marinho raso (antepraia) destes depósitos pode ser assegurada pela presença de tocas em forma de tubos fossilizados de Callichirus, cuja zona de vida, no caso de espécie encontrada (C.major), corresponde à zona de maré baixa conforme SUGUIO \& MARTIN (1976b), SUGUIO et al. (1984) e RODRIGUES et al. (1984). Esta origem é também confirmada pelas estruturas sedimentares singenéticas, tais como as estratificações cruzadas de baixo ângulo $\theta$ espinha-de-peixe. Na superfície, os terraços exibem vestígios de antigas cristas praiais, que podem ser facilmente diferenciadas dos terraços holocênicos (MARTIN et al., 1981b).

Nas porções mais internas das planícies costeiras a altitude desses terraços chega a 8-9 m, diminuindo rumo ao oceano normalmente até 5-6 $\mathrm{m}$. Por vezes, a passagem para os terraços holocênicos é visualizada por falésias de poucos metros, como acontece na área de São Mateus.

Contrariamente ao que ocorre muito nos terraços holocênicos, os pleistocênicos não contém fragmentos de conchas, que foram certamente dissolvidas por ácido húmico. No sul do Estado da Bahia, um recife de corais situado sob o terraço representativo do penúltimo nivel marinho mais alto foi amostrado e datado pelo método do lo/U (MARTIN et al., 1982). Oito amostras de coral do gênero Siderastrea, provenientes de uma "pedreira" abandonada, foram coletadas aleatoriamente $e$ destas, somente cinco compostas integralmente de aragonita foram datadas. Quatro delas forneceram idades comparáveis entre si com valor médio de $123.500 \pm 5.700$ anos A.P. Os terraços pleistocênicos da planície costeira do Rio Doce, estando em continuidade com os do sul da Bahia, devem ter sido construídos na mesma época de nivel marinho mais alto.

Terraços marinhos holocênicos - Situados externamente em relação aos terraços marinhos pleistocênicos e, freqüentemente separados deles por zona baixas e pantanosas, ocorrem os terraços marinhos holocênicos. Esses depósitos contém muitas vezes conchas de moluscos, são mais raramente impregnados por matéria orgânica secundária e apresentam alinhamentos muito nítidos sobre fotografias aéreas.

Ocorrem várias gerações de terraços holocênicos, nitidamente discerniveis na porção norte da planície costeira. Os mais internos formam espécies de "ilhas arenosas" separadas entre si por zonas baixas e pantanosas. Sabe-se que eles são mais antigos do que 3.500 anos A.P., pois três sambaquis construídos sobre esses terraços forneceram idades correspondentes a 4.400 \pm 150 anos A.P. (SPC-027), 4.240 \pm 150 anos A.P. (SPC-034) e $3.550 \pm 150$ anos A.P. (Bah-951). Deste modo, pode-se imaginar que eles tenham sido formados entre 5.100 e 3.800 anos A.P., 
correspondente à primeira fase de emersão holocênica do litoral brasileiro. Os mais externos formam uma faixa praticamente contínua na margem oceânica, interrompendo-se apenas nas desembocaduras dos rios São Mateus, Ipiranga e Doce. Esses terraços são separados dos internos por uma zona babxa composta por sedimentos lagunares $\theta /$ ou paludiais.

b) Depósitos lagunares - A maior parte da planície costeira situada entre os terraços pleistocênicos (ou sedimentos da Formação Barreiras) e os cordões holocênicos externos $\theta$ atualmente ocupada por uma zona pantanosa recoberta por depósitos turfosos de cerca de 0,5 m de espessura. Ababxo desses sedimentos paludiais, ocorrem materiais areno-argilosos orgânicos, contendo freqüentemente conchas de moluscos marinhos ou lagunares (Ostrea, Anomalocardia, etc.), além de fragmentos vegetais incarbonizados, provavelmente depositados em paleolagunas.

Datações por radlocarbono de conchas de moluscos e fragmentos de madeira permitiram distinguir duas fases lagunares. As amostras coletadas entre os terraços pleistocênicos(ou Formação Barreiras) e a primeira geração de cristas praiais holocênicas (partes central e sul da planície costeira) forneceram as seguintes idades:

Número da amostra

a) Conchas

PP-009A

RD-30

RD-31

PB-152

PP-009B

RD-21

PP-009C

$\mathrm{RD}-34$

RD-32

RD-24
Idade radiocarbono

(anos A.P.)

$6.350 \pm 200$

$6.280 \pm 200$

$6.280 \pm 200$

$6.150 \pm 250$

$6.030 \pm 250$

$6.020 \pm 200$

$5.880 \pm 230$

$5.800 \pm 200$

$5.600 \pm 200$

$5.550 \pm 200$
Referência de laboratório

SPC-006

Bah-954

Bah-955

SPC-010

SPC-014

Bah-950

SPC-005

Bah-957

Bah-956

Bah-952

b) Madeiras

RD-13

$4.670 \pm 200$

Bah-966

RD-12

$4.620 \pm 200$

Bah-965

RD-14

$4.600 \pm 200$

Bah-967 
Por outro lado, as amostras coletadas entre a primeira e segunda geração de cristas praiais holocênicas (metade norte da planície costeira) acusaram as seguintes idades:

Número da amostra

\section{Idade radiocarbono}

(anos A.P.)

a) Conchas

RD-01

RD-10

RD-07

b) Madeira

RD-28
$3.540 \pm 150$

$3.300 \pm 200$

$3.060 \pm 150$

$3.430 \pm 150$
Referência de laboratório

Bah-942

Bah-946

Bah-944

Bah-962

A fase lagunar mais antiga corresponde à época de submersão anterior a 5.100 anos A.P., quando o nível do mar esteve 4 a $5 \mathrm{~m}$ acima do atual. Após 5.100 anos A.P., o nível abaixou lentamente mas continuando a ser superior ao atual até cerca de 4.100 anos A.P. A primeira fase lagunar deve ter existido neste período. As conchas acusaram idades sempre superiores a 5.500 anos A.P. sugerindo que a influência marinha tenha sido dominante durante a fase de submersão, enquanto que a influência continental, representada por fragmentos de madeira, tenha prevalecido na fase de emersão.

A fase lagunar mais recente está relacionada ao nivel mais alto do que o atual entre 3.600 e 3.000 anos A.P. Esta fase é também reconhecida por evidências de invasão lagunar encontradas na porção externa da primeira geração de cristas praiais.

Um testemunho de sondagem obtido nesta região lagunar, entre as duas gerações de cristas praiais, mostrou a superposição de duas formações laguno-marinhas separadas por sedimentos fluviais (Fig. 21). A formação inferior não foi datada, porém, conchas amostradas da formação superior indicaram uma idade de 3.500 \pm 150 anos A.P., perfeitamente de acordo com o segundo período de submersão anteriormente identificado. Além disso, lagunas de formas em geral alongadas puderam ser originadas entre os terraços arenosos holocênicos, durante as fases de abaixamento do nivel marinho (MARTIN \& DOMINGUEZ, no prelo). 

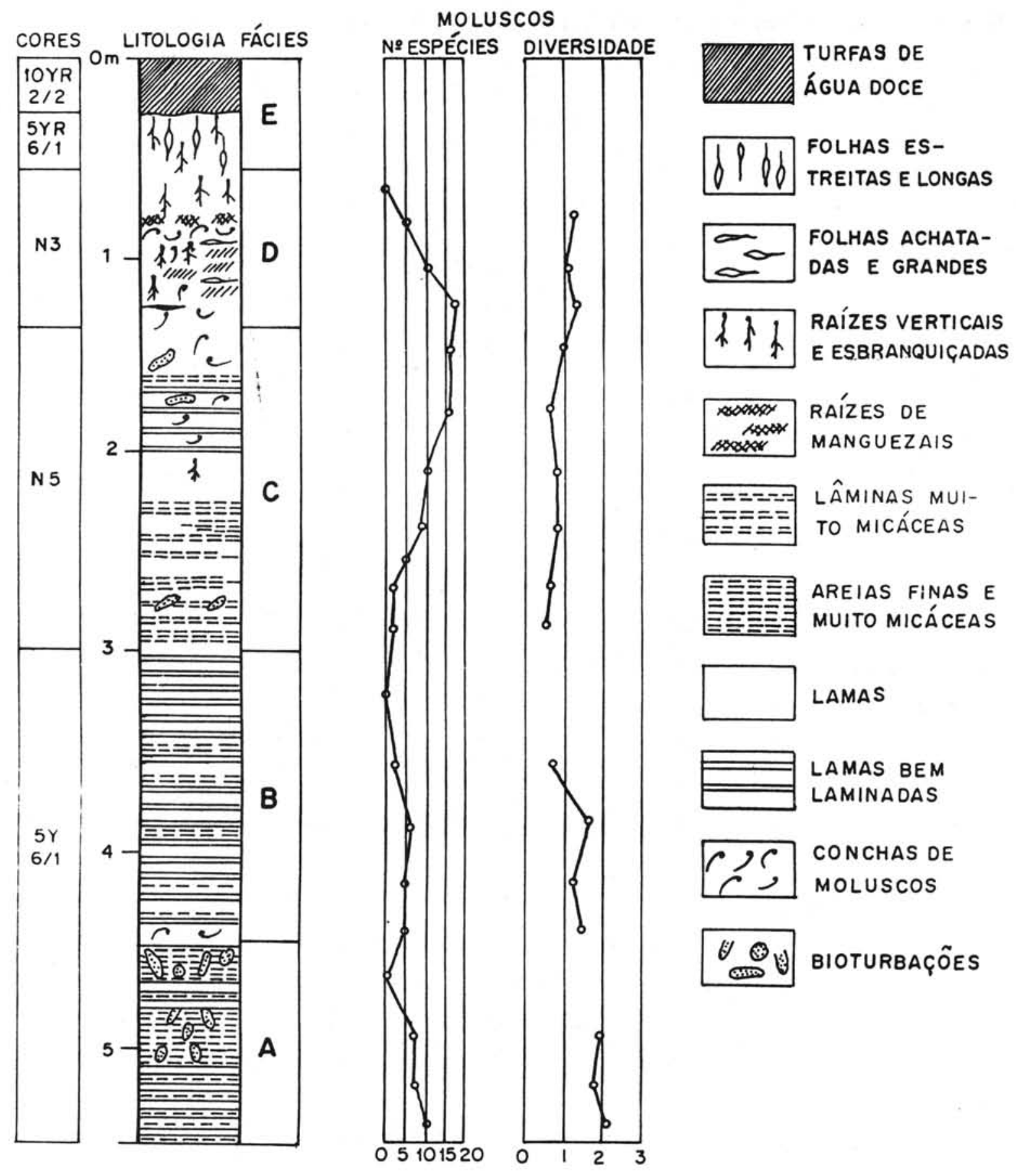

Figura 21 - Testemunho de sondagem obtido no furo RD-15, com descrição sucinta das composiçōes litológica e faunística sugestivas da superposição de duas seqüências de sedimentação lagunar. 
c) Depósitos fluviais - Na metade sul da planície costeira. margeando o curso atual do Rio Doce, ocorre uma grande extensão de sedimentos fluviais, representados por depósitos de paleocanais e de transbordamento (Fig. 20). Além dos paleocanais norte e sul, que são os mais importantes, existem outros de menor importância. BANDEIRA JÚNIOR et al. (op.cit.) demonstraram que os sedimentos de paleocanais foram depositados sob condições de energia mais fraca do que as existentes no Rio Doce atual.

Sondagens realizadas na área mostraram que, abaixo dos sedimentos fluviais, ocorrem sedimentos argilosos contendo conchas de moluscos (BANDEIRA JÚNIOR et al., op.cit.), certamente correlacionáveis aos depósitos lagunares acima descritos.

Uma vista em planta da zona dos depósitos fluviais mostra todas as características de um delta dominado por processos fluviais, segundo a classificação de GALOWAY (1975). Parece evidente que, no passado, o Rio Doce desembocava em uma laguna, onde foi construido então o delta.

Os sedimentos fluviais do curso inferior do Rio São Mateus são muito pouco importantes e os ligados ao Rio Barra Seca são praticamente inexistentes.

d) Depósitos de manguezais - Só aparecem no setor norte do delta, margeando os rios Mariricu e São Mateus, onde eles se aproximam do oceano.

\subsubsection{Evolução paleogeográfica}

a) Pesquisas anteriores

A planície da foz do Rio Doce já havia sido estudada em diferentes escalas por BACOCCOU (1971) e por BANDEIRA JÚNIOR et al. (1975).

Segundo BACOCCOL (op.cit.), a planície costeira do Rio Doce teria sido formada a partir de uma acreção lateral de cristas praiais (Fig. 22). A paleolaguna e o delta intralagunar não foram identificados por este autor, embora eles sejam bem visíveis nas fotografias aéreas, provavelmente porque esses dois elementos não coadunem com deltas em cúspide dominados por ondas. Além disso, todos os eventos geológicos da planície foram considerados como holocênicos.

Por outro lado, embora BANDEIRA JÚNIOR et al. (op.cit.) tenham executado um trabalho bem mais detalhado do que o de BACOCCOLI (op.cit.), ainda não conseguiram interpretar corretamente a evolução da planície costeira, principalmente por falta de informações sobre o abaixamento de nível relativo do mar nos últimos 5.000 anos. Portanto, também neste caso, não foram reconhecidos os terrenos arenosos pleistocênicos e nem a paleolaguna e o delta intralagunar associado.

b) Modelo proposto neste trabalho

Reconstruções paleogeográficas baseadas em um mapa geológico não 


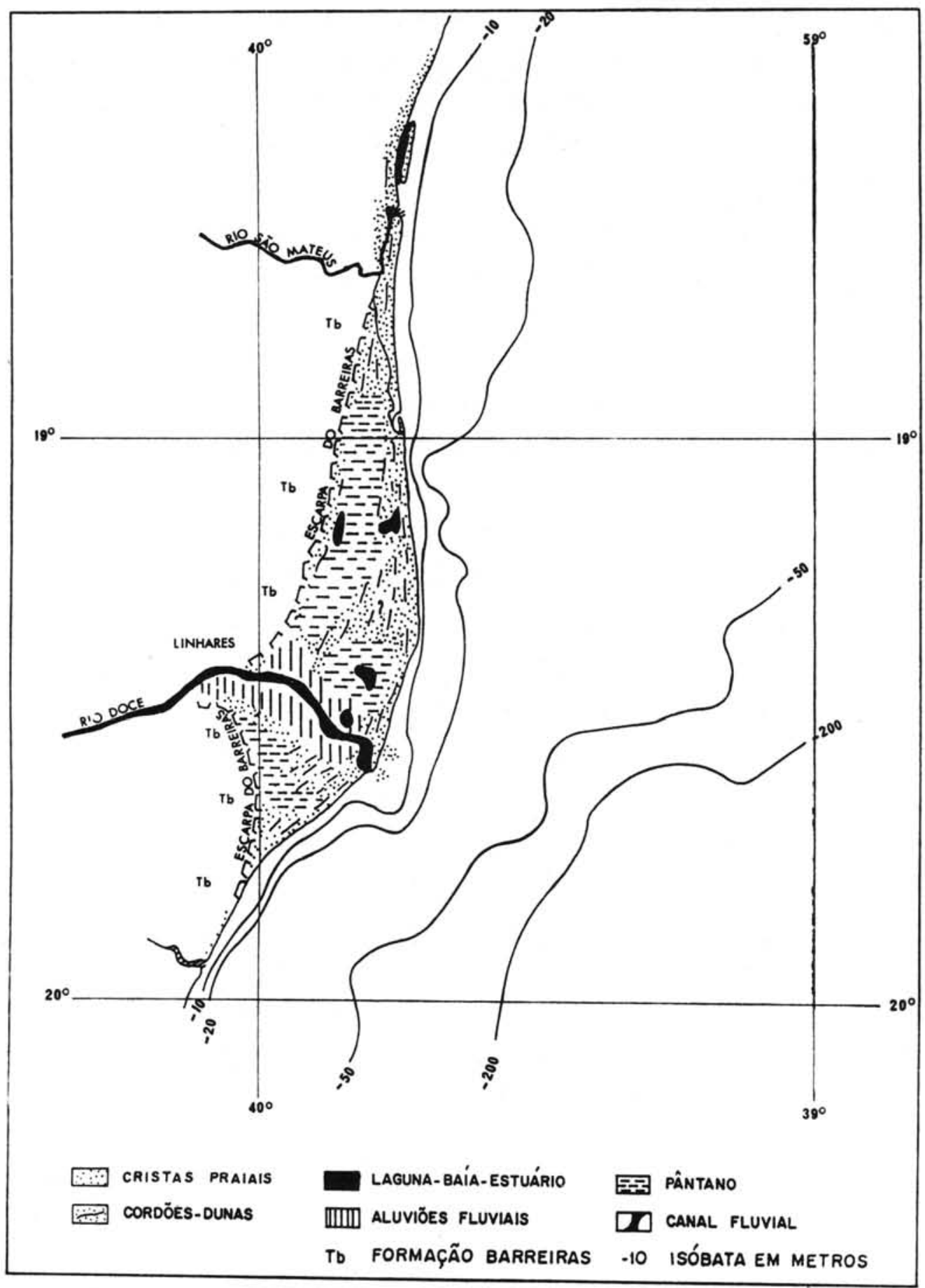

Figura 22 - Mapa geológico esquemático do "delta" do Rio Doce segundo BACOCCOL (1971). 
interpretativo, datações por radiocarbono, conhecimento das flutuações de nível relativo do mar durante os últimos 7.000 anos $\theta$ suas conseqüências na sedimentaçăo litorânea, bem como um estudo detalhado da geometria dos alinhamentos de antigas cristas praiais, permitiram estabelecer com boa precisão as diferentes etapas na formação da planície costeira do Rio Doce.

Os primeiros estádios do modelo evolutivo geral do litoral brasilleiro entre Macá́ (RJ) e Maceió (AL), apresentado previamente são diretamente aplicáveis à planície costeira da foz do Rio Doce:

\section{- Estádio 1: Deposição dos sedimentos terciários continentais da Formação} Barreiras (Fig. 23A).
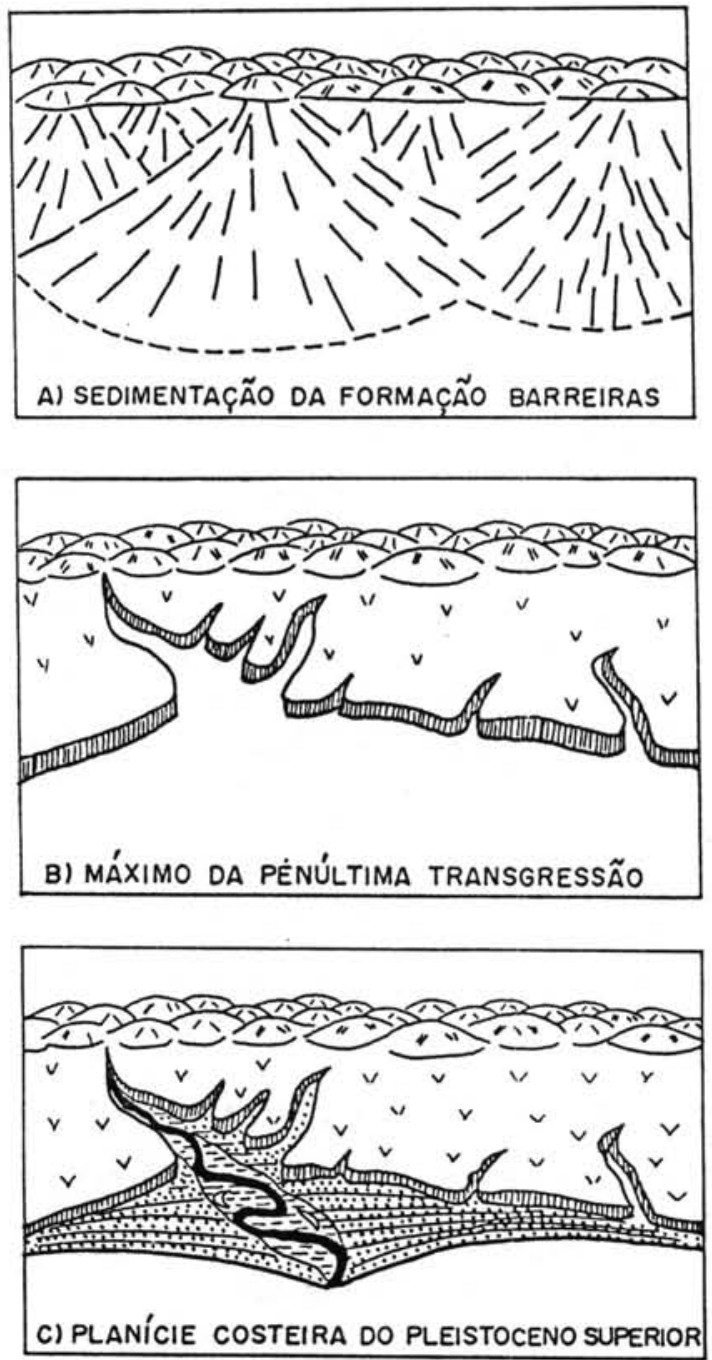

Figura 23 - Esquemas evolutivos da planície costeira do Rio Doce do fim do Terciário (sedimentação de leques aluviais coalescentes da Formação Barreiras) ao Pleistoceno superior (máximo da penúltima transgressão e a formação de planície de cristas praiais regressivas). 
- Estádios 2 e 3: Não estão aqui representados.

- Estádio 4: Corresponde ao máximo do penúltimo período de nivel marinho mais alto ( \pm 123.000 anos A.P.). Por ocasião desta transgressão, os sedimentos continentais pós-Barreiras, eventualmente presentes, devem ter sido erodidos formando-se uma linha de falésias na Formação Barreiras. Nesta época, o nível relativo do mar situava-se $8 \pm 2 \mathrm{~m}$ acima do atual. Os amplos vales escavados nos sedimentos terciários devem ter sido afogados e o curso inferior do Rio Doce fol transformado em estuário (Fig. 23B).

- Estádio 5: Deposição de areias marinhas pleistocênicas ao sopé das falésias entalhadas na Formação Barreiras. As entradas dos vales afogados foram fechadas por barreiras arenosas que propiciaram a formação de lagunas. Paralelamente, o estuário do Rio Doce fol colmatado, formando-se assim uma ampla planicie sedimentar, do qual restam hoje em dia somente alguns vestigios (Fig. 23C).

A partir do estádio 6, que no modelo geral corresponde ao máximo da última transgressão, a evolução da planície costeira do Rio Doce póde ser acompanhada com muito maior detalhe, tendo sido estabelecidos alguns dos episódios essenciais como, por exemplo:

- A construção da porção holocênica da planície costeira do Rio Doce, que teve início com a formação de um sistema de ilhas-barreiras/laguna. Datação por radiocarbono de conchas $\mathrm{e}$ fragmentos de madeira coletados nos sedimentos desta antiga laguna mostraram que ela existia já há cerca de 7.000 anos A.P., época na qual o nivel do mar ultrapassou o atual. É evidente que nesta época as ilhas-barreiras deveriam situar-se em posições mais externas e que elas atingiram suas posições finais na época do máximo da transgressão em torno de 5.100 anos A.P.

- Existência de um vasto delta intralagunar, que começou a se formar logo após o estabelecimento da laguna ("corpo permanente de água em relativo repouso"). Entretanto, até ao máximo da transgressão (5.100 anos A.P.), a laguna deve ter sido dominada pelo mar em ascensão, que pode ter sido um obstáculo ao desenvolvimento do delta intralagunar. Deste modo, as conchas de moluscos coletadas nos sedimentos lagunares indicaram idades compreendidas entre 7.000 e 5.000 anos A.P. (laguna dominada pelo oceano), enquanto que as idades situadas entre 5.000 e 4.000 anos A.P. foram obtidas sobre pedaços de madeira (laguna dominada pelo rio).

- Existência de terraços arenosos cobertos de cristas praiais na porção externa das ilhas-barreiras - O mapeamento detalhado dos alinhamentos de cristas praiais que recobrem esses terraços mostra a existência de conspícuas discordâncias (Fig. 24). Elas representam sucessões de períodos de acumulação e de erosão, indicando modificações na hidrodinâmica litorânea em conseqüência, seja devida a variações do nivel relativo do mar (elevação provoca erosão e abaixamento produz acumulação), seja devida a inversōes no sentido de transporte litorâneo. 


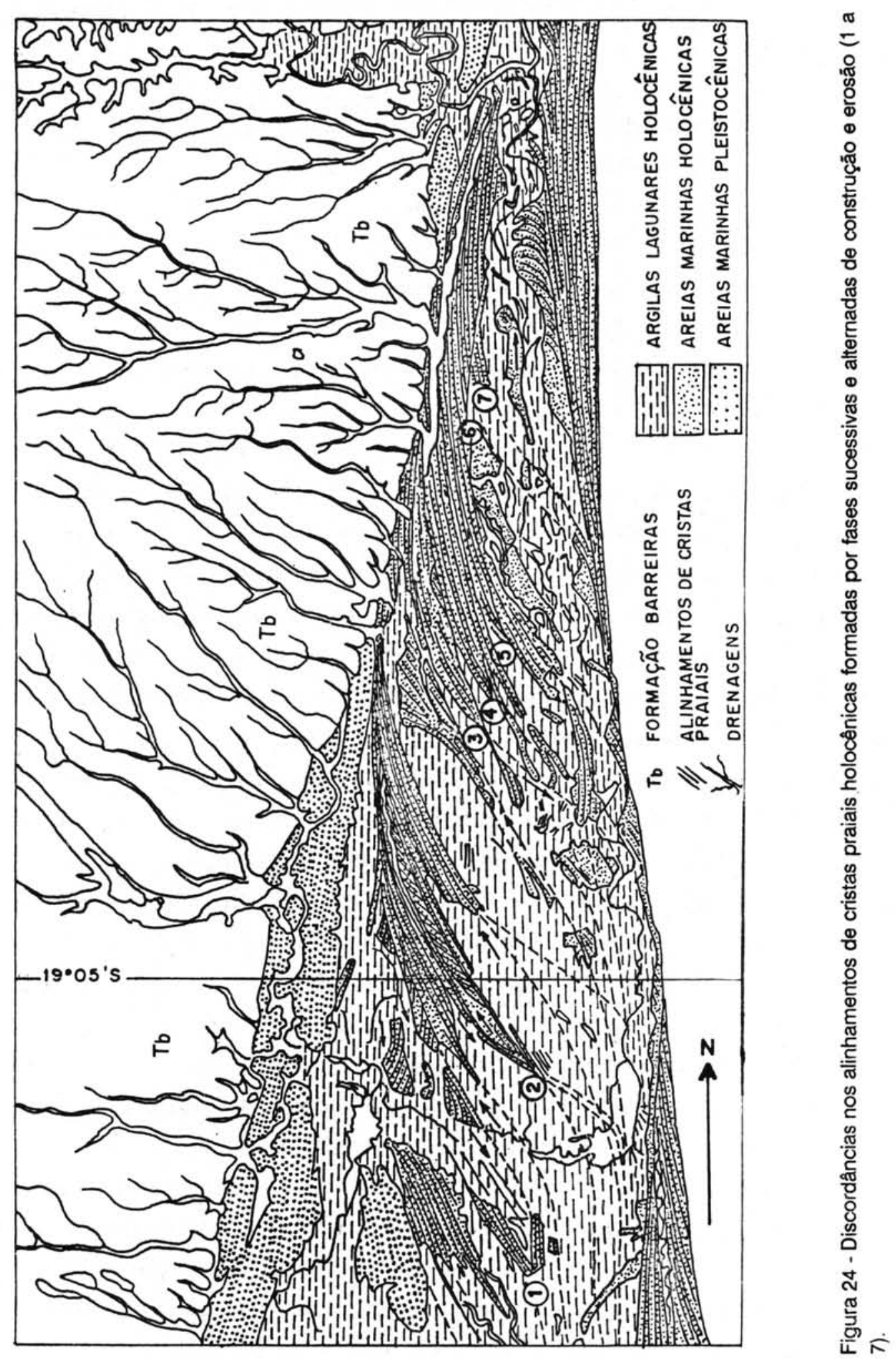


O estudo das variações do nivel relativo do mar mostrou que ocorrem três períodos de elevação:

- antes de 5.100 anos A.P.,

- entre 3.900 e 3.600 anos A.P. $\theta$

- entre 2.700 e 2.500 anos A.P.

e três períodos de abaixamento:

- entre 5.100 e 3.900 anos A.P.,

- entre 3.600 e 2.700 anos A.P. $\theta$

- após 2.500 anos A.P.

Desta maneira, a evolução holocênica da pląnície costeira do Rio Doce pode ser dividida em vários estádios e subestádios seguintes:

Estádio A: Fase anterior a 5.100 anos A.P. (Fig. 25) - Esta etapa corresponde à formação de um sistema de ilhas-barreiras/laguna que, conforme já foi visto, existia há cerca de 7.000 anos A.P. e as ilhas-barreiras haviam atingido suas posições finais há aproximadamente 5.100 anos A.P. Embora não tenhamos dados para reconstruir a geometria das ilhas-barreiras antes de $\mathbf{5 . 1 0 0}$ anos A.P., as suas posições finais no momento do nível máximo são bem conhecidas. Foi visto também que a partir do momento em que houve a formação da laguna, os sedimentos transportados pelo Rio Doce passaram a ser af trapeados. Não se dispõe de informaçőes que permitam acompanhar o crescimento inicial do delta intralagunar. Um problema importante consiste em determinar a época na qual o Rio Doce passou a desembocar diretamente no oceano, contribuindo com a sua carga arenosa na edificação dos terraços marinhos cobertos por cristas praiais. Sobre isto, pode-se admitir duas possibilidades: (a) que o delta intralagunar tenha colmatado rapidamente a laguna e certos braços tenham atingindo muito cedo o oceano, ou (b) que o "brusco" abalxamento de nivel relativo do mar entre 4.200 e 3.900 anos A.P. tenha provocado a saída simultânea de diversos braços ativos do delta intralagunar no oceano. Com base em alguns dados pode-se pensar que o delta intralagunar tenha se desenvolvido no interior da laguna até cerca de 4.200 anos A.P. De fato, será visto mais adiante que cinco distributários do Rio Doce parecem ter atingido mais ou menos simultaneamente o oceano. Como eles apresentam importâncias variávels podé-se pensar que, se as suas saidas diretamente ao oceano foram provocadas pela colmatação da laguna, os diversos distributários não teriam atingido simultaneamente o oceano. Por outro lado, deve-se notar que os cursos inferiores dos paleocanais não são margeados por sedimentos fluvlais, fato que favorece a ldéla de uma saida brusca para o oceano. É importante notar que a geometria das cristas praiais é profundamente modificada a partir do momento em que um braço do delta intralagunar atinge diretamente o oceano. Datação por radiocarbono de uma amostra coletada nas cristas praiais ligadas ao inicio de funcionamento de uma 


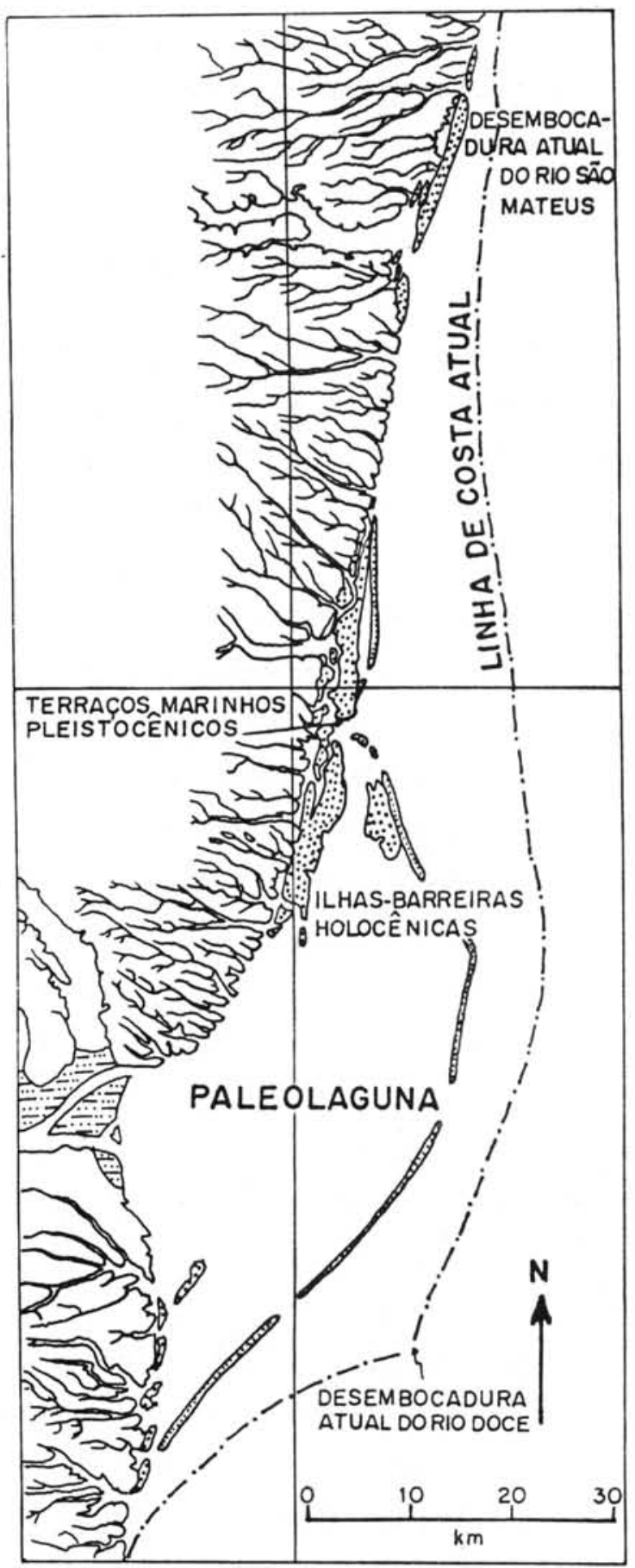

Figura 25 - Estádio A: Fase anterior a 5.100 anos A.P. - Situação do sistema ilhas-barreiras/laguna ao redor de 5.100 anos A.P., correspondente ao nível máximo holocênico. Podem ser vistos testemunhos de terraços marinhos pleistocênicos, situação da linha de costa atual e as posições atuais das desembocaduras dos rios Doce e São Mateus. 
dessas desembocaduras fluviais indicou um idade de $3.940 \pm 200$ anos A.P. (Bah-964), o que está perfeitamente de acordo com uma saída dos diversos braços em conseqüência do abaixamento do nivel relativo do mar entre 4.200 e 3.900 anos A.P. Por outro lado, sedimentos lagunares coletados debaixo do paleocanal deste mesmo braço do Rio Doce foram datados de $4.670 \pm 200$ anos A.P. (Bah966). É então evidente que há cerca de 4.600 anos A.P. a parte frontal do delta intralagunar situava-se em posição claramente mais interna do que a sua posição final e, portanto, ainda estava em construção.

DOMINGUEZ $(1987,1989)$, ao contrário, pensa que o delta intralagunar ocupava, já há cerca de 5.100 anos A.P., a maior parte da zona central da laguna e que conseqüentemente o Rio Doce teria saído diretamente para o oceano muito cedo, contribuindo assim para a construção dos terraços arenosos. Nós vimos que a geometria das cristas praiais era profundamente modificada por uma desembocadura fluvial ativa. Portanto, não é possível ligar geometricamente as paleodesembocaduras existentes com os depósitos arenosos que são formados na porção norte da planície entre 5.100 e 4.100 anos A.P. Contrariamente, a evolução das desembocaduras pode ser acompanhada de modo contínuo nos terraços arenosos que foram formados após 3.600 anos A.P.

Embora a paleolaguna apresentasse pouca profundidade nas suas porções laterais, o paleoestuário do Rio Doce era muito profundo e, desta maneira, teria exigido grande volume de sedimentos para o seu assoreamento, como se pode verificar pela profundidade das lagoas (mais de $30 \mathrm{~m}$ ) que ocupavam os imensos vales tributários do Rio Doce.

Essas diferenças de interpretação, embora sejam importantes no que concerne às fontes de areias que serviram para a construção da primeira geração de cristas praiais holocênicas, não intervém na geometria dos alinhamentos dessas cristas. De fato, elas dependem essencialmente da direção de transporte litorâneo e, portanto, do quadrante no qual as ondas atingem a costa. Quando existem vários sistemas de ondas, podemos chamar de ondas eficazes as que são capazes de promover transporte resultante em uma dada direção.

Estádio B: Período entre 5.100 e 4.200 anos A.P. - No instante de nível máximo do mar de 5.100 anos A.P., a configuração do sistema de ilhas-barreiras deve ter sido tal que existia, na porção norte da planície, uma concavidade acentuada que teria servido de armadilha para areias transportadas pela corrente de deriva litorânea. Antes da saída direta do Rio Doce para o oceano, esta concavidade parece ter sido preenchida e a linha costeira estava praticamente retificada. Este preenchimento deve ter ocorrido por progradação da linha de costa do sul para o norte. Deste modo, entre 5.100 e 4.200 anos A.P. deve ter sido originada a primeira geração de terraços arenosos holocênicos sob condições hidrodinâmicas geradas por ondas eficazes do setor sul. Por outro lado, examinando-se atentamente a geometria dos alinhamentos de cristas praiais, constata-se que existem 
no mínimo sete discordâncias conspícuas (Fig. 24), correspondentes a igual número de eventos erosivos que sucederam a fases deposicionais ligadas a condições hidrodinâmicas de ondas eficazes do setor sul. Deste modo, fica claro que existem sete retomadas de modificações hidrodinâmicas em conseqüência da inversão nos sentidos das ondas eficazes.

Subestádio B-1: Primeira fase de construção (Fig. 26) - A concavidade formada, ao norte, pelo sistema de ilhas-barreiras começou a ser preenchida sob o efeito de transporte litorâneo sul-norte, isto é, sob influência de ondas eficazes provenientes do setor sul. Esporões arenosos são destacados da costa na altura da curva que marca o início da concavidade. Sob influência da refração das ondas, esses esporões arenosos foram recurvados e unidos uns aos outros. $O$ desligamento inicial dos esporões arenosos deve ter propiciado a formação de pequenas lagunas alongadas, pois é possível reconstruir uma desembocadura lagunar ao norte desta primeira zona de acumulação. A presença de cristas praiais recurvadas para o interior da paleolaguna mostra que esta desembocadura era, do ponto de vista de energia, dominada pelo oceano e então que ela não poderia corresponder à desembocadura do Rio Doce. Se as condições hidrodinâmicas tivessem continuado estáveis a progradação teria progredido sem interrupção.

Subestádio B-2: Primeira fase de erosão (Fig. 27) - Uma discordância importante no alinhamento das cristas praiais mostra que aquela primeira fase de construção foi interrompida por um período de erosão localizada. Esta fase de erosão, subseqüente à fase construtiva, não poderia ser explicada senão por uma modificação radical na hidrodinâmica local. A erosão sendo localizada, não poderia ser o resultado de uma subida de nível relativo do mar, mas resultante de uma inversão na direção das ondas eficazes. De fato, após a inversão de direção das ondas eficazes, a antiga linha de costa deve ter-se tornado instável e a porção em desequilíbrio fora erodida até que novo ponto de equilibrio fosse atingido. Pode-se também verificar que ao norte da desembocadura, um esporão arenoso recurvado desenvolveu-se do norte para o sul. Isto confirma a existência de transporte litorâneo do norte para o sul, em função de ondas eficazes provenientes do norte. Então, é evidente que durante todo este período, as ondas do setor sul ligadas às passagens de frentes frias, não puderam atingir a desembocadura do Rio Doce e, conseqüentemente, as ondas do setor norte, embora mais fracas, tornam-se eficazes. Paralelamente, o delta intralagunar continuou a desenvolverse no interior da laguna.

Subestádio B-3: Segunda fase de construção (Fig. 28) - Um retorno às condições hidrodinâmicas iniciais deve ter provocado a retomada da progradação rumo ao norte sob o efeito do transporte litorâneo sul-norte, em virtude de ondas eficazes provenientes do setor sul. Esta fase de progradação traduziu-se principalmente pela construção de um esporão arenoso que isolou uma laguna secundária alongada de cerca de $20 \mathrm{~km}$ de comprimento por 3 a $4 \mathrm{~km}$ de largura. 


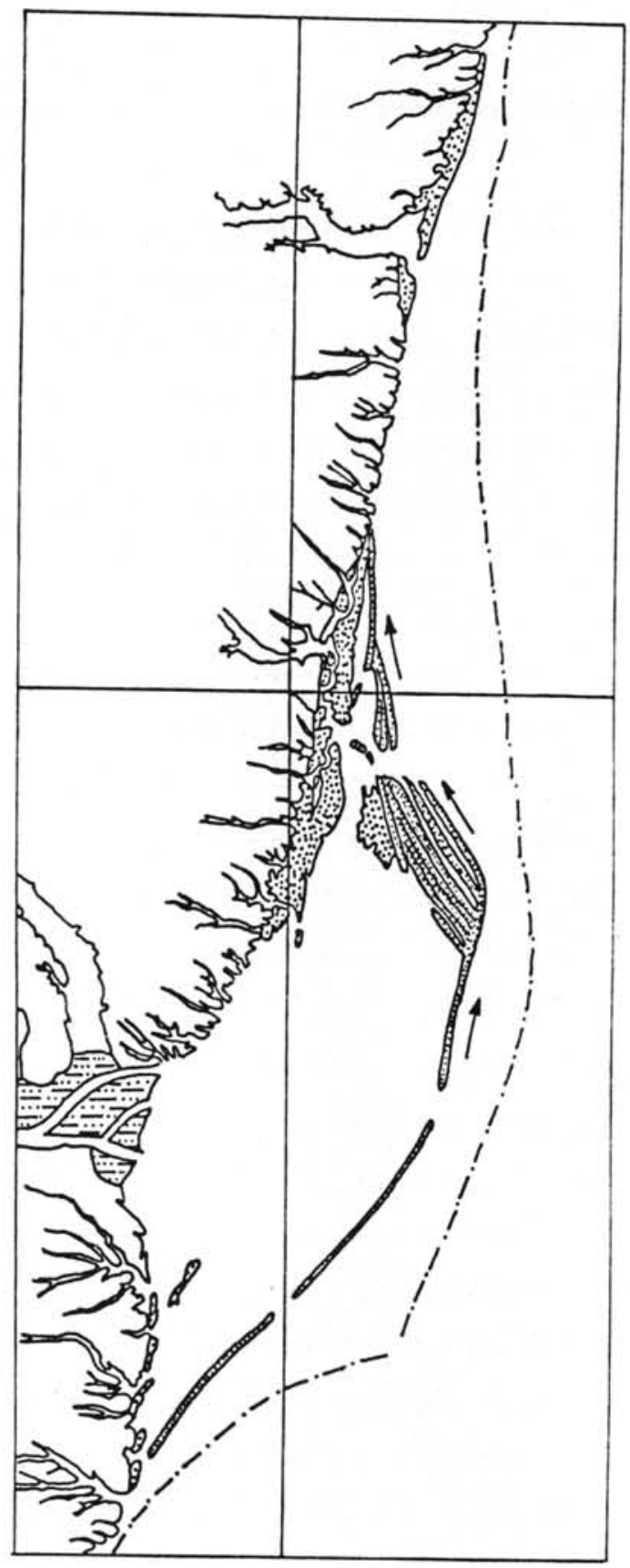

Figura 26 - Subestádio B-1: Primeira fase de construção do intervalo de tempo correspondente a 5.100-4.200 anos A.P.

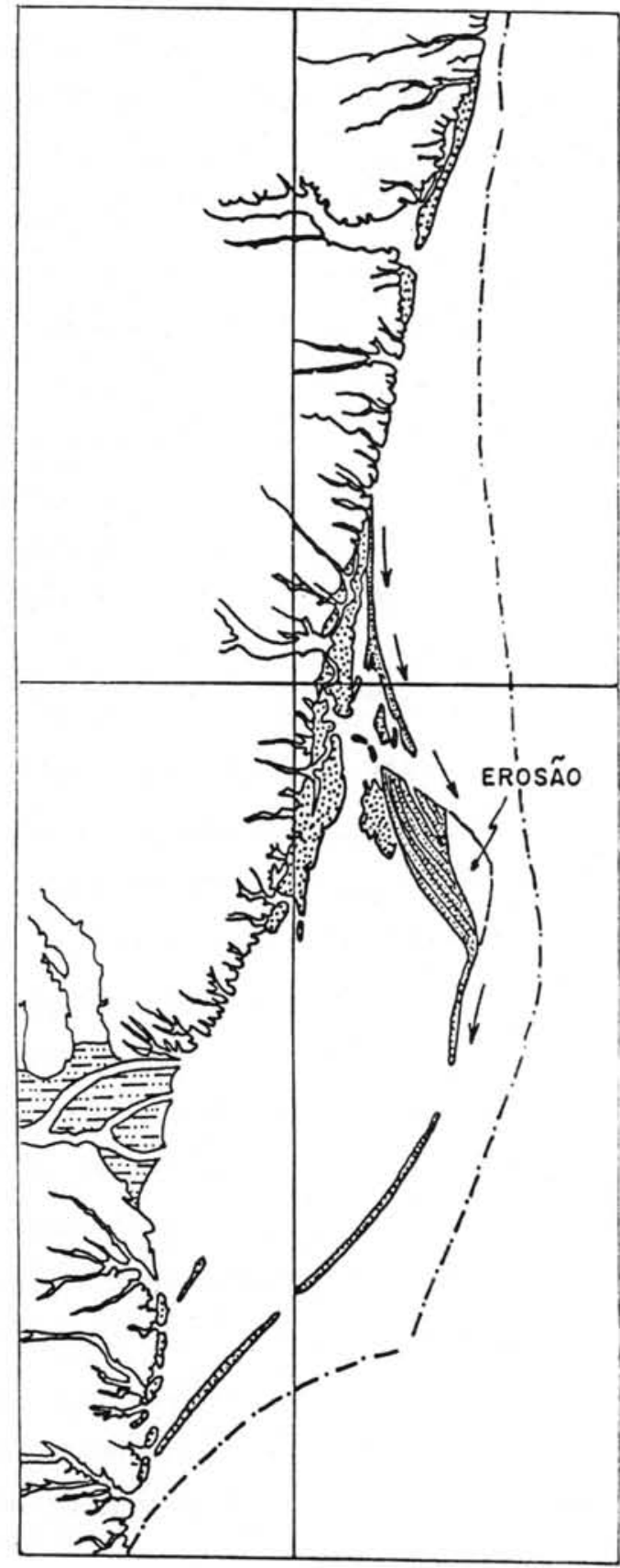

Figura 27 - Subestádio B-2: Primeira fase de erosão do intervalo de tempo correspondente a 5.100-4.200 anos A.P. 
Subestádio B-4: Segunda fase de erosão (Fig. 29) - Uma outra descontinuidade nos alinhamentos das cristas praiais marca a ocorrência de um novo período erosivo, correspondente à modificação das condições hidrodinâmicas, ligadas à nova inversão do transporte litorâneo $\theta$, portanto, as ondas eficazes provieram do setor norte.

Subestádio B-5: Terceira fase de construção (Fig. 30) - Um novo retorno às condições hidrodinâmicas iniciais, geradas pelas ondas eficazes do setor sul, provocou a retomada da progradação rumo ao norte. Este processo não parece ter consistido de acreção lateral regular de cristas praiais mas por uma alternância de faixas arenosas separadas por zonas lagunares alongadas de grandes dimensões. Testemunhagens executadas nessas antigas lagunas mostraram que elas resultaram realmente do isolamento de porções da antepraia por esporões arenosos.

Subestádio B-6: Terceira fase de erosão (Fig. 31) - Uma terceira discordância multo nitida nos alinhamentos das cristas praiais marca a ocorrência de nova fase de modificação das condições hidrodinâmicas ligadas à inversão das ondas eficazes, que passaram a provir do setor norte.

Subestádio B-7: Quarta fase de construção (Fig. 32) - O retorno às condições hidrodinâmicas iniciais sob influência de ondas eficazes do setor sul provocou a retomada da progradação para o norte. Este processo foi acompanhado pelo isolamento de uma laguna secundária alongada.

Subestádio B-8: Quarta fase de erosão (Fig. 33) - Outra discordância muito bem demarcada nos alinhamentos das cristas praiais acusa a ocorrência de novo período de mudança nas condições hidrodinâmicas, relacionadas à inversão no sentido de atuação das ondas eficazes que passaram a provir do setor norte.

Subestádio B-9: Quinta fase de construção (Fig. 34) - Novo retorno às condições hidrodinâmicas iniciais sob influência de ondas eficazes do setor sul deve ter provocado o reinício de progradação para o norte. Este processo ocorreu de modo semelhante aos eventos precedentes.

Subestádio B-10: Quinta fase de erosão (Fig. 35) - Nova discordância nos alinhamentos das cristas praiais registra a ocorrência de um outro período de modificações hidrodinâmicas relacionadas à inversão das ondas eficazes, que passaram a provir do setor norte.

Subestádio B-11: Sexta fase de construção (Fig. 36) - Um retorno às condições hidrodinâmicas iniciais sob influência das ondas eficazes provenientes do setor sul provocou a retomada da progradação para o norte, nas mesmas condições que previamente.

Subestádio B-12: Sexta fase de erosão (Fig. 37) - Nova superfície de discordância nos alinhamentos das cristas praiais acusa a ocorrência de uma nova fase de modificação nas condições hidrodinâmicas ligadas à inversão na direção das ondas eficazes, que passaram a atuar do norte. 


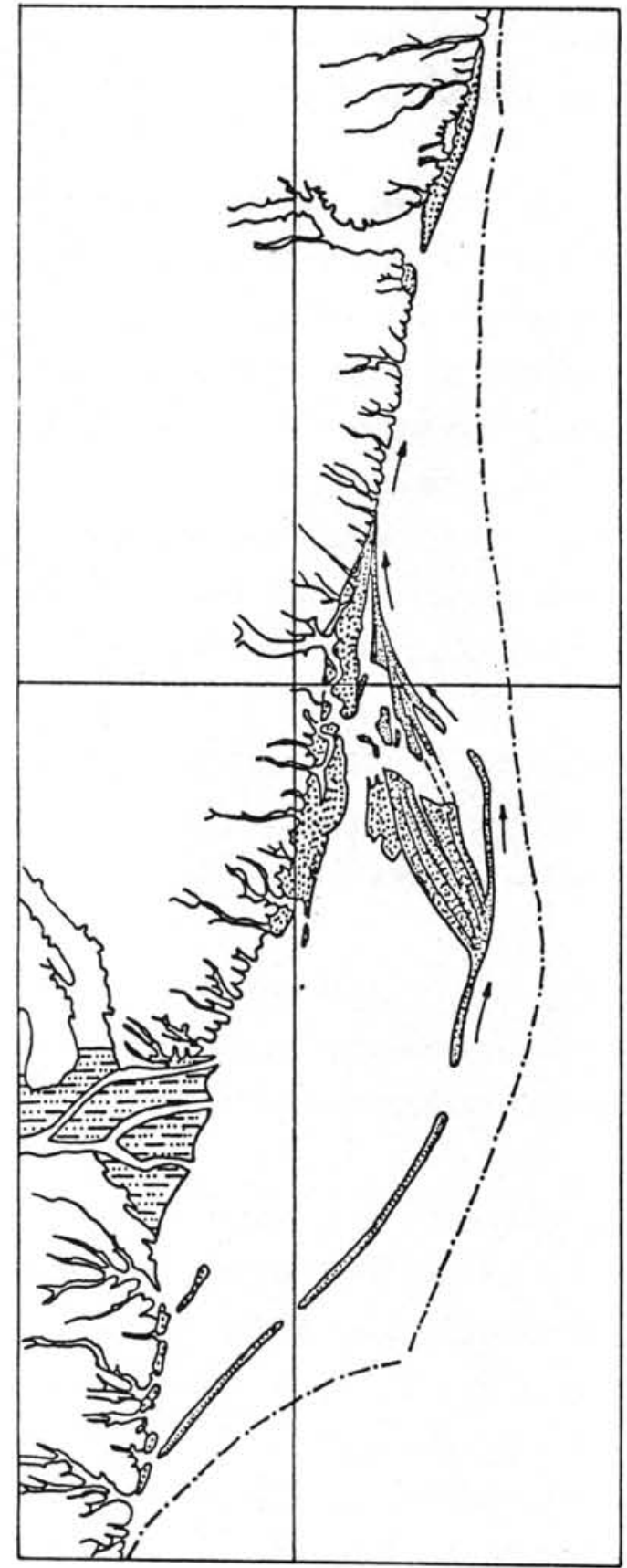

Figura 28 - Subestádio B-3: Segunda fase de construção do intervalo de tempo correspondente a 5.100-4.200 anos A.P.

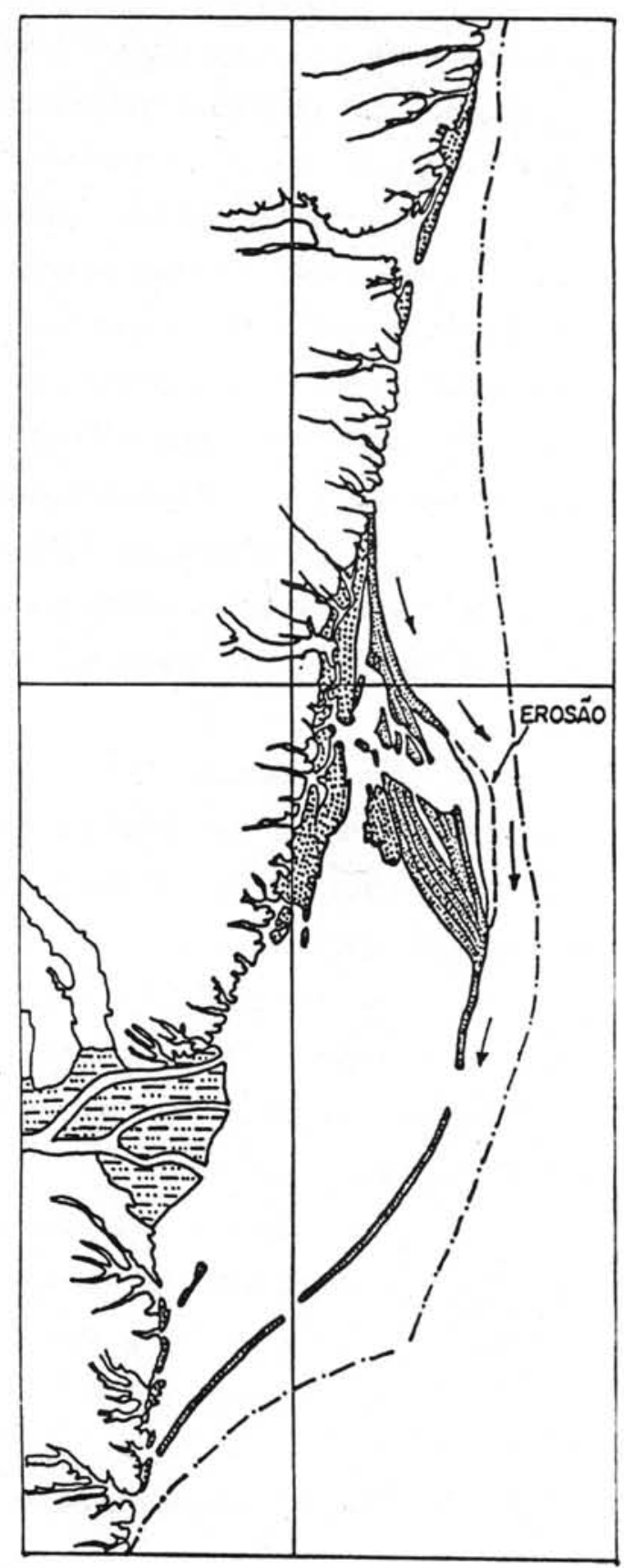

Figura 29 - Subestádio B-4: Segunda fase de erosão do intervalo de tempo correspondente a 5.100-4.200 anos A.P. 


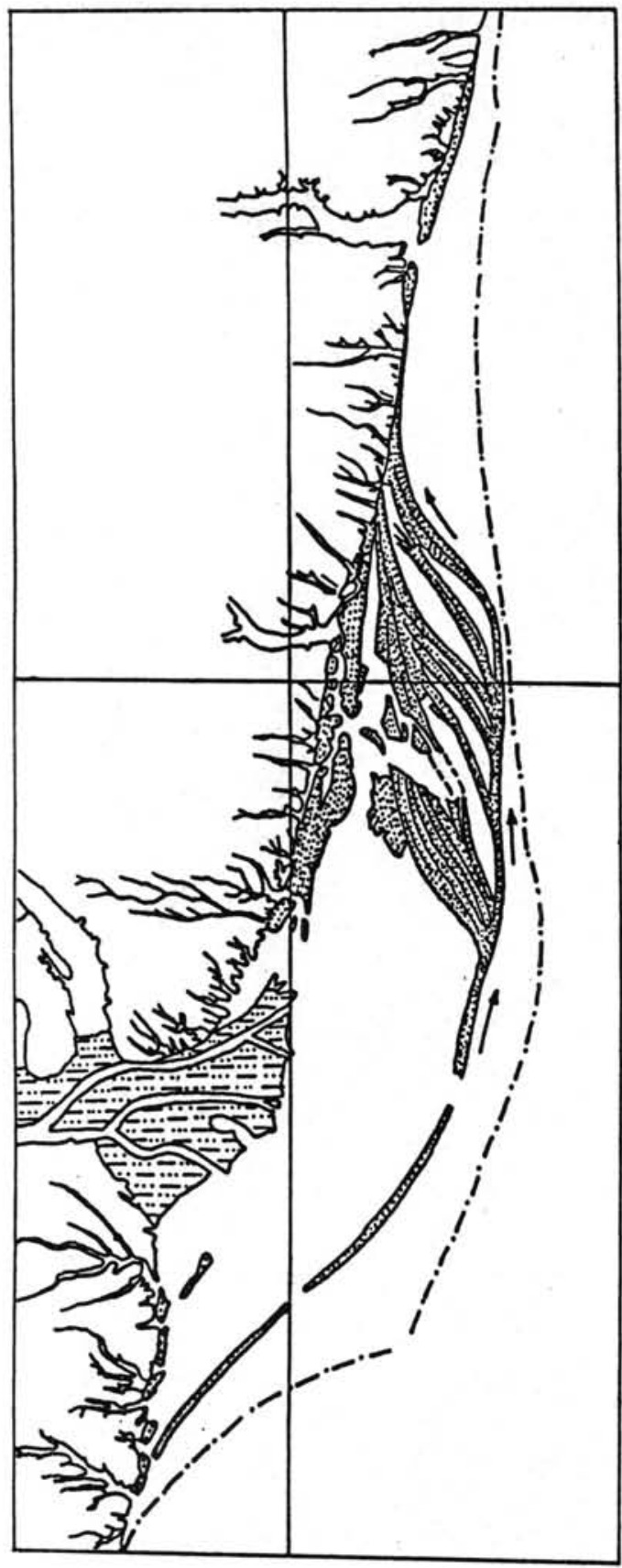

Figura 30 - Subestádio B-5: Terceira fase de construção do intervalo de tempo correspondente a 5.100-4.200 anos A.P.

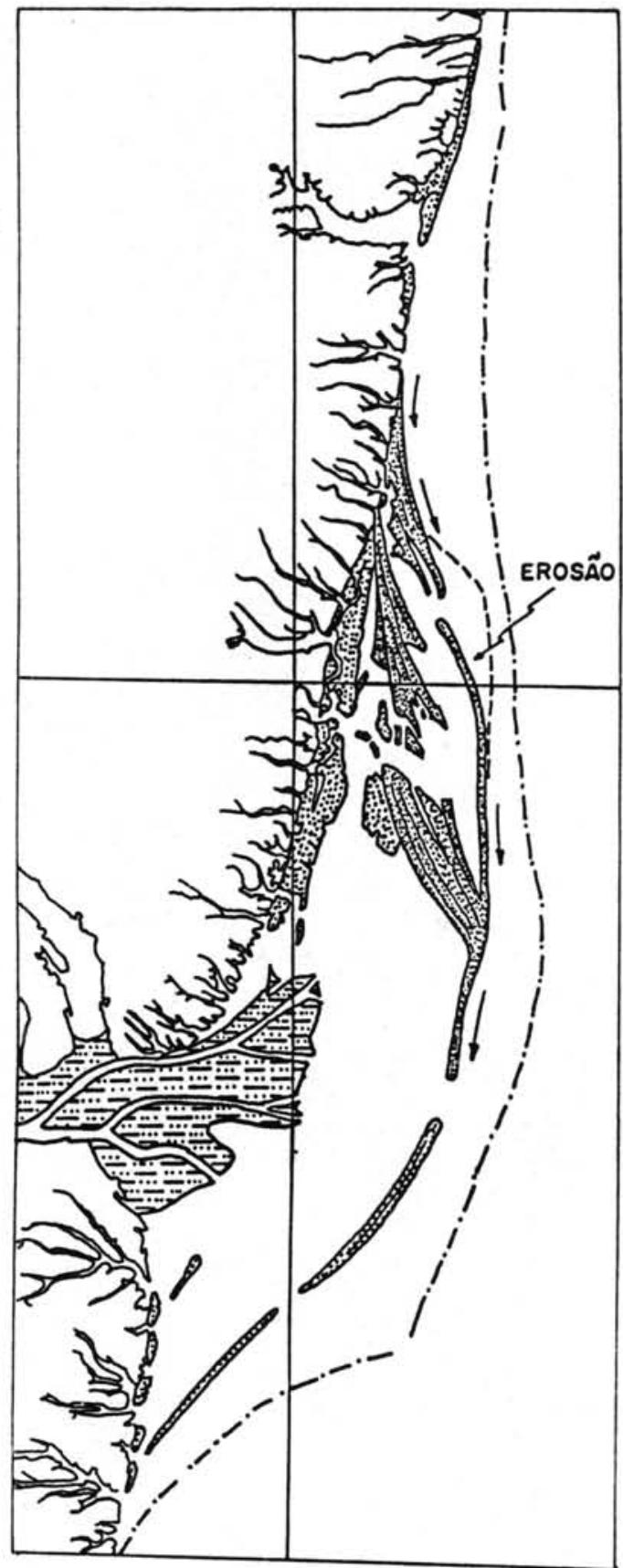

Figura 31 - Subestádio B-6: Terceira fase de erosão do intervalo de tempo correspondente a 5.100-4.200 anos A.P. 


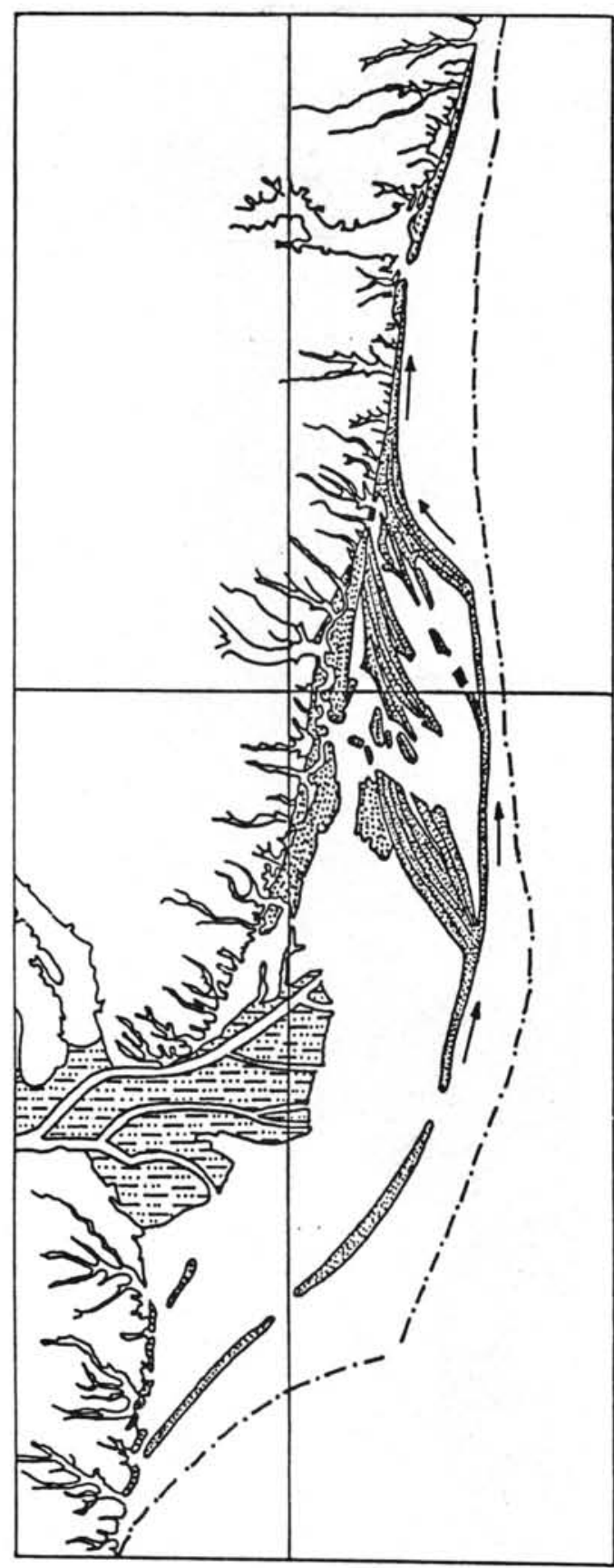

Figura 32 - Subestádio B-7: Quarta fase de construçāo do intervalo de tempo correspondente a 5.100-4.200 anos A.P.

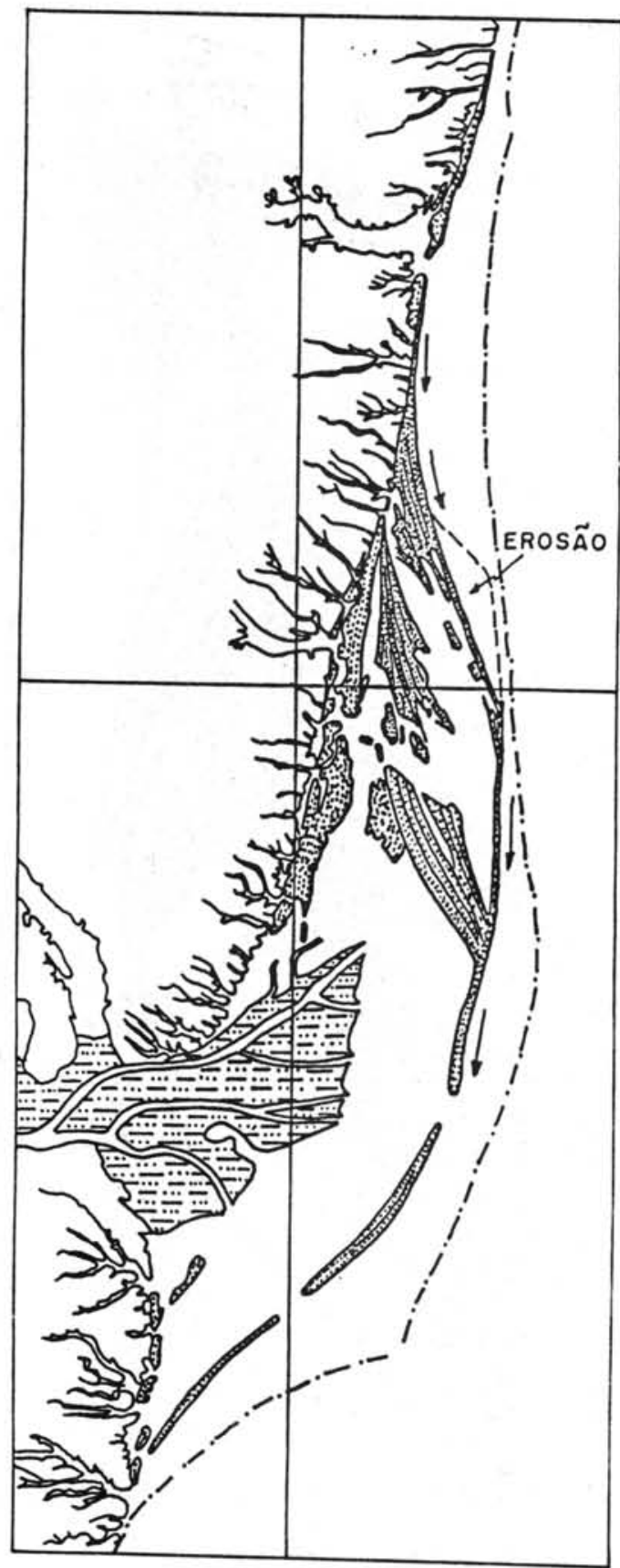

Figura 33 - Subestádio B-8: Quarta fase de erosão do intervalo de tempo correspondente a 5.100-4.200 anos A.P. 


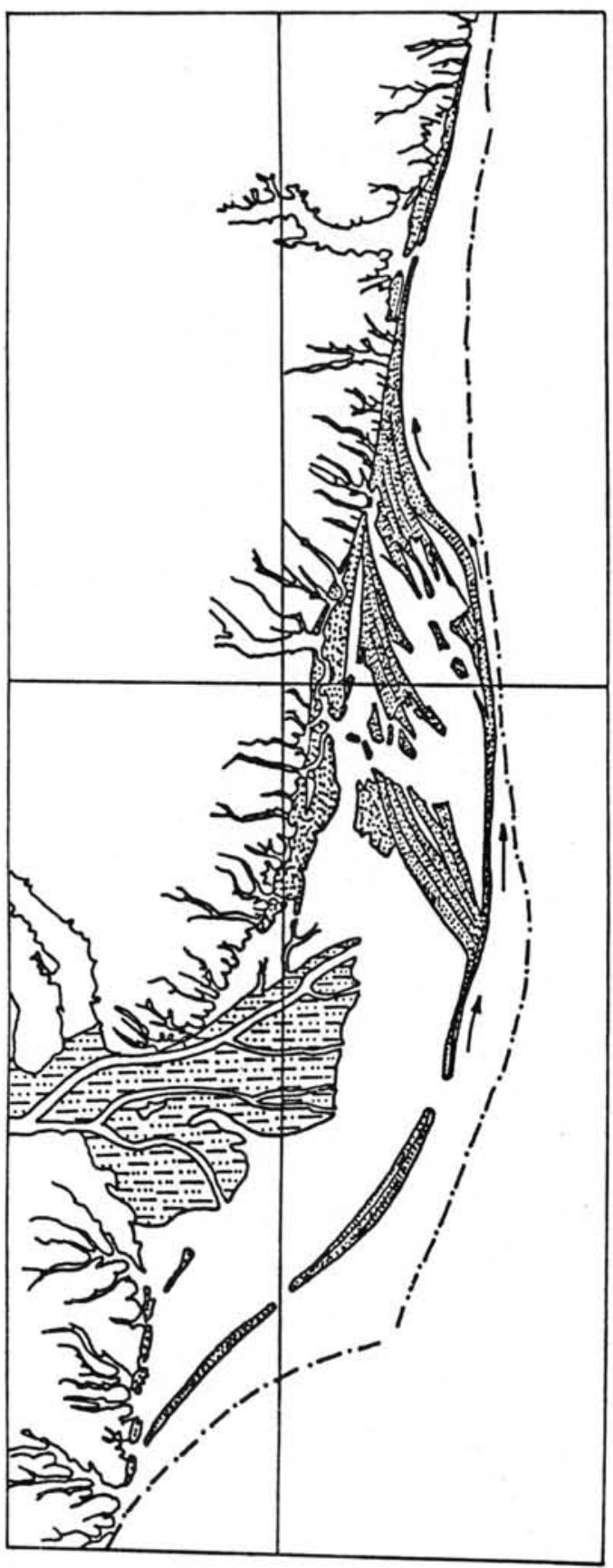

Figura 34 - Subestádio B-9: Quinta fase de construção do intervalo de tempo correspondente a 5.100-4.200 anos A.P.

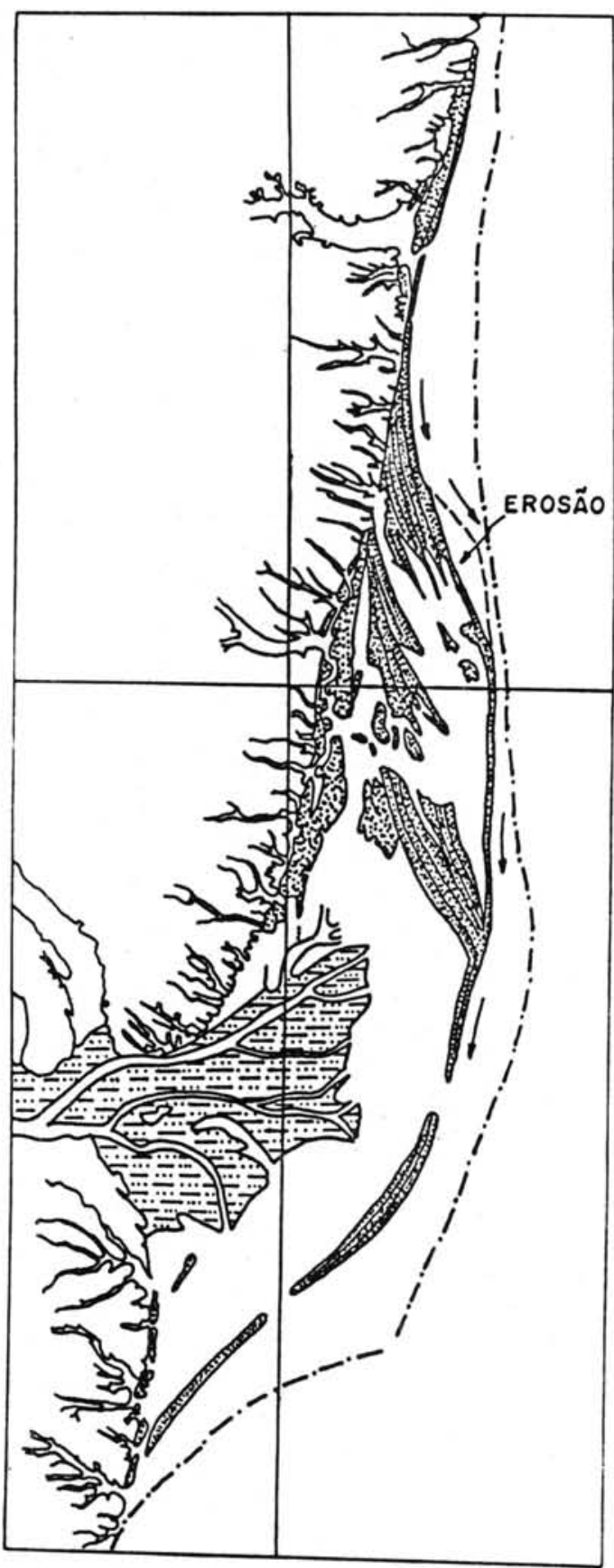

Figura 35 - Subestádio B-10: Quinta fase de erosão do intervalo de tempo correspondente a 5.100-4.200 anos A.P. 


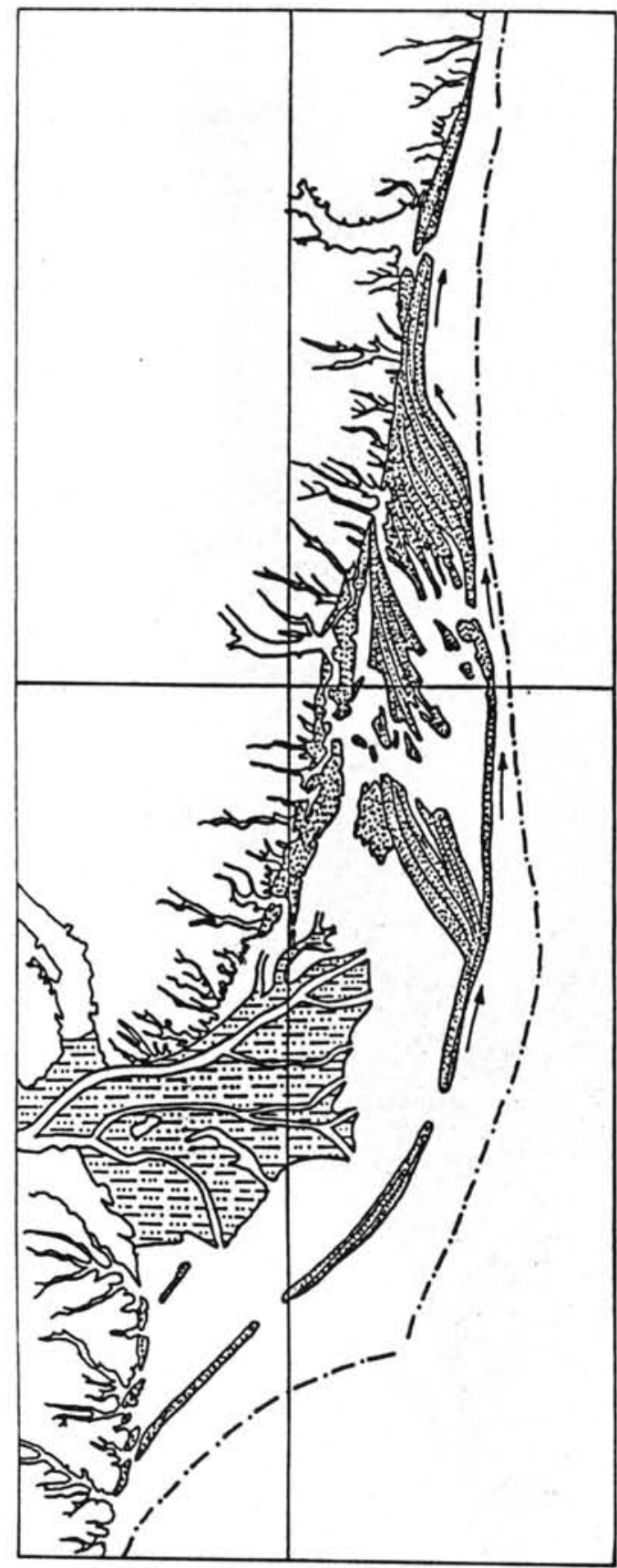

Figura 36 - Subestádio B-11: Sexta fase de construção do intervalo de tempo correspondente a 5.100-4.200 anos A.P.

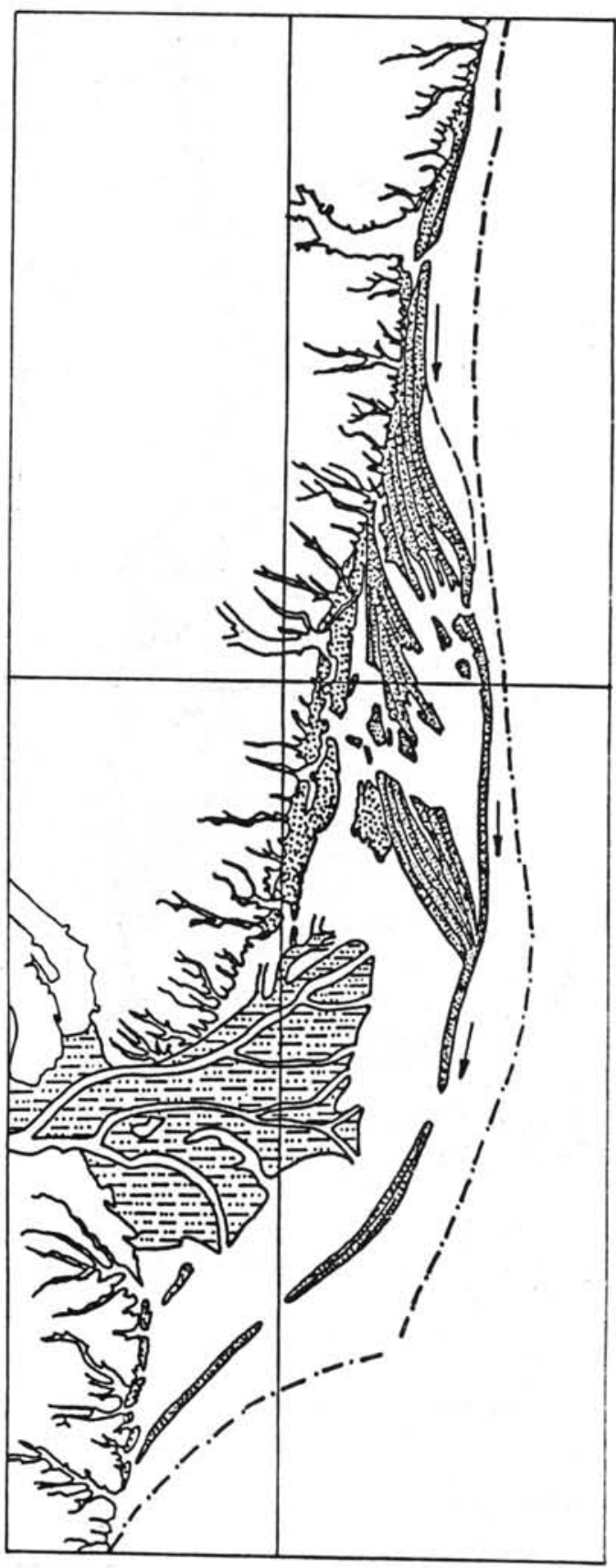

Figura 37 - Subestádio B-12: Sexta fase de erosão do intervalo de tempo correspondente a 5.100-4.200 anos A.P. 
Subestádio B-13: Sétima fase de construção (Fig. 38) - A volta às condições hidrodinâmicas iniciais sob influência das ondas eficazes provenientes do setor sul provocou a retomada da progradação para norte.

Subestádio B-14: Sétima fase de erosão (Fig. 39) - Nova discordância nos alinhamentos das cristas praiais marca a existência de novo período de modificação nas condições hidrodinâmicas relacionadas à inversão na direção das ondas eficazes, que passaram a ser do setor norte.

Subestádio B-15: Oitava fase de construção (Fig. 40) - Um retorno às condições hidrodinâmicas iniciais sob influência de ondas eficazes do setor sul provocou a retomada da progradação para o norte. Neste momento, a concavidade inicial que serviu de "armadilha sedimentar" estava praticamente preenchida $\theta$ a linha de costa quase retificada.

Naturalmente, ao longo desses estádios o delta intralagunar prosseguiu o seu desenvolvimento no interior da laguna. Nesta época, o delta intralagunar possula dois canais distributários principais e três secundários, todos ativos porém nenhum desembocava diretamente no oceano.

Estádio C: Entre 4.200 e 3.900 anos A.P. - Já foi visto que este intervalo de tempo foi marcado por um "rápido" abaixamento do nivel do mar de 2 a $3 \mathrm{~m}$. Na porção central da planície costeira do Rio Doce, em frente ao delta intralagunar, é possivel evidenciar através da geometria das cristas praiais, as posições prováveis das cinco desembocaduras (Fig. 41). A reconstrução paleogeográfica que pode ser feita a partir da geometria das cristas praiais, de um e de outro lado das cinco desembocaduras, sugere que elas tenham começado a funcionar praticamente ao mesmo tempo e que, conseqüentemente, os cinco distributários do delta intralagunar tenham atingido mais ou menos simultaneamente o oceano (Fig. 42). É evidente que a saída simultânea dos cinco braços do delta intralagunar só pode ser explicada como conseqüência de um fenômeno global, isto é, abaixamento "brusco" de nível relativo do mar. Em caso contrário, seria muito difícil que eles atingissem o oceano praticamente ao mesmo tempo.

Como resultado desta saída do Rio Doce diretamente ao oceano através dos cinco distributários ( $\mathrm{A}$ a E da Fig. 42), a dinâmica de sedimentação arenosa deve ter sido completamente modificada. A primeira zona de sedimentação holocênica, localizada ao norte da planície, na concavidade formada pelas ilhas-barreiras, foi definitivamente abandonada. Por outro lado, uma nova zona de sedimentação começava a atuar na porção sul da planície, relacionada às cinco desembocaduras que passavam a controlar a geometria da deposição. Pode-se ver que o setor da costa, situado entre as desembocaduras A e B, encontrava-se em desequilibrio pela saída direta do Rio Doce no oceano. Este desequilibrio foi traduzido por erosão da porção central deste setor da costa 


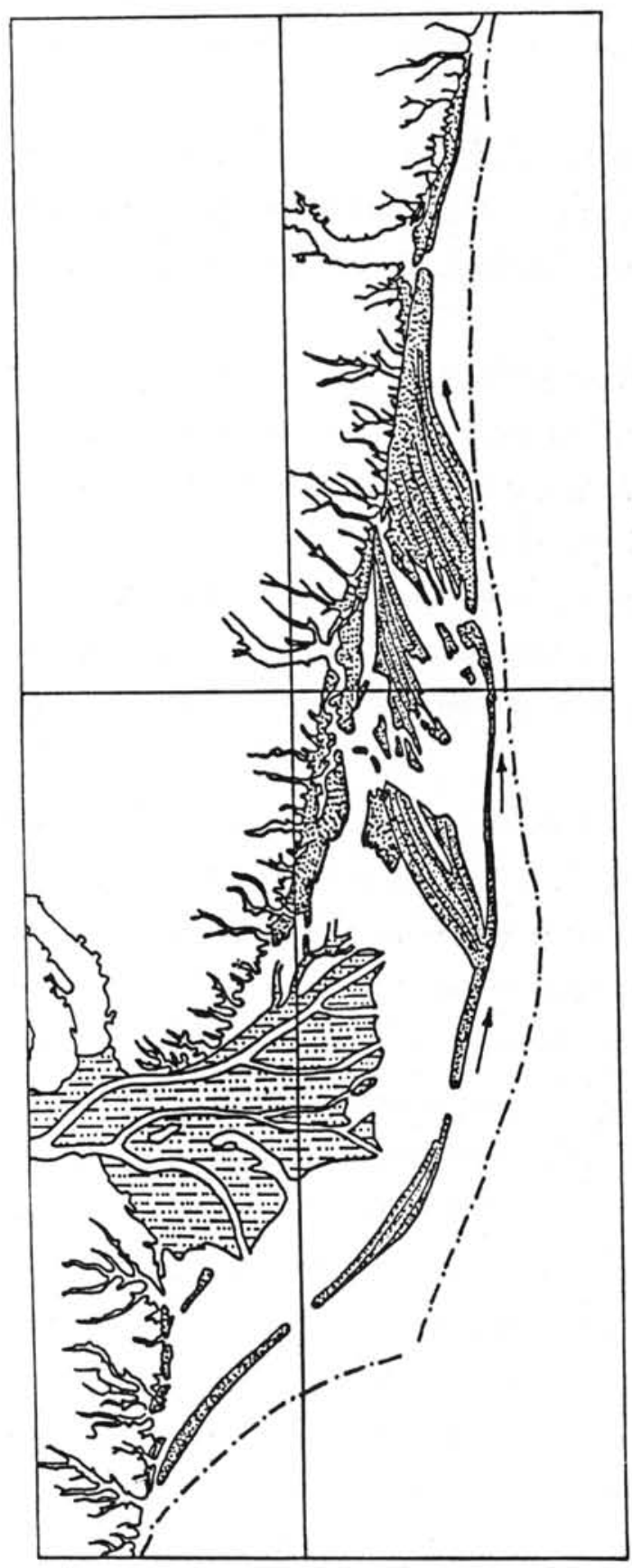

Figura 38 - Subøstádio B-13: Sétima fase de construção do intervalo de tempo correspondente a 5.100-4.200 anos A.P.

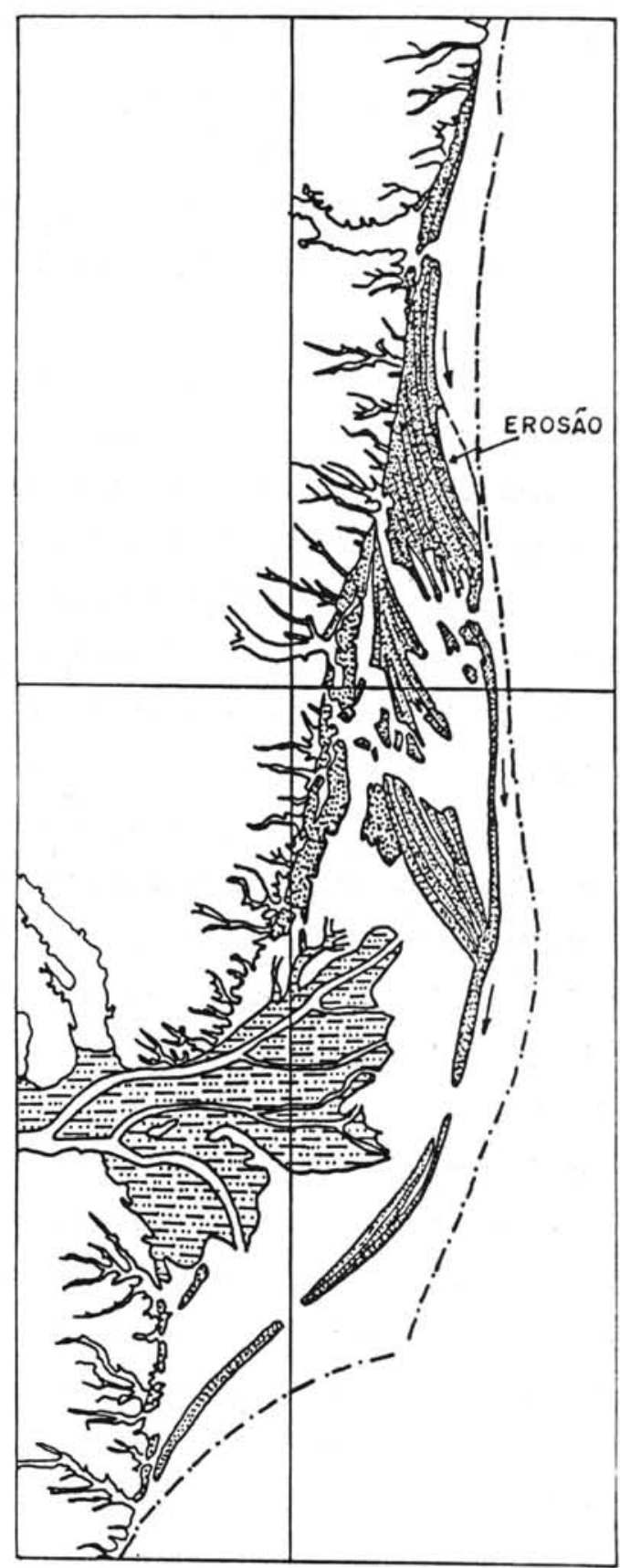

Figura 39 - Subestádio B-14: Sétima fase de erosão do intervalo de tempo correspondente a 5.100-4.200 anos A.P. 


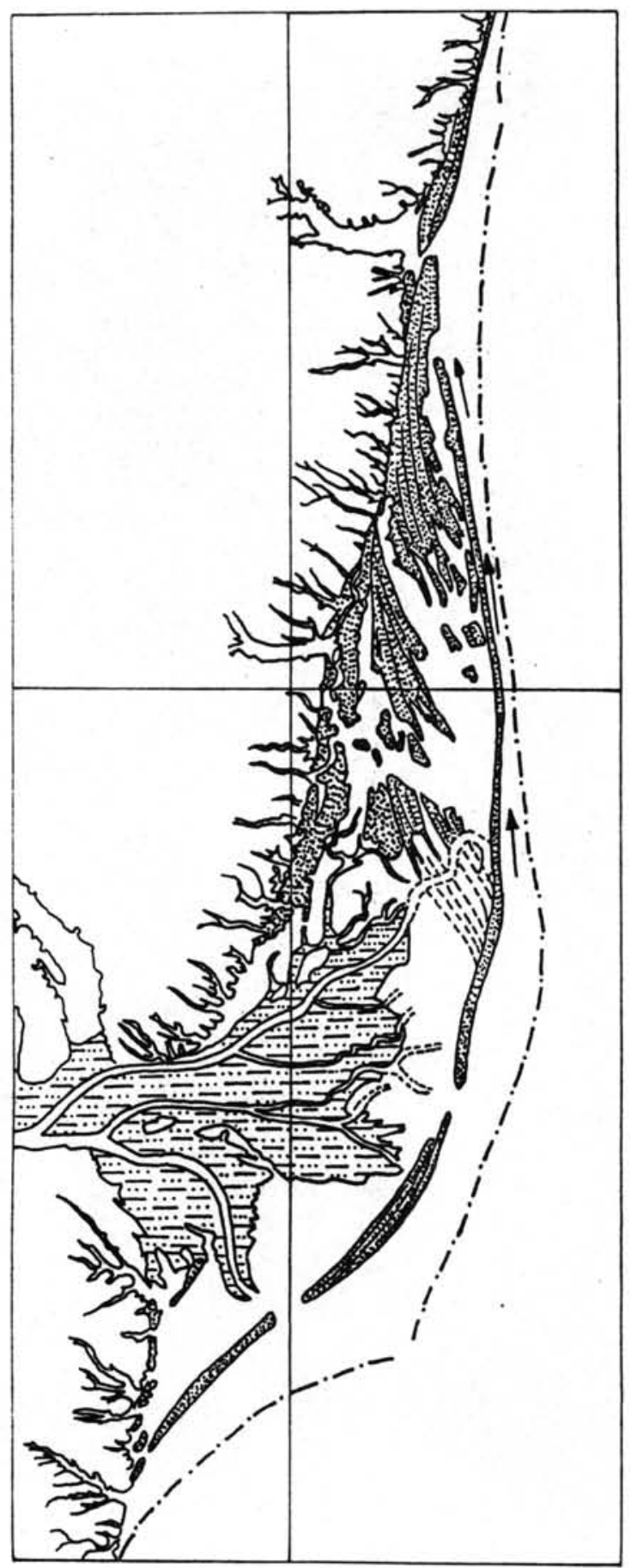

Figura 40 - Subestádio B-15: Oitava fase de construção do intervalo de tempo correspondente a 5.100-4.200 anos A.P. 


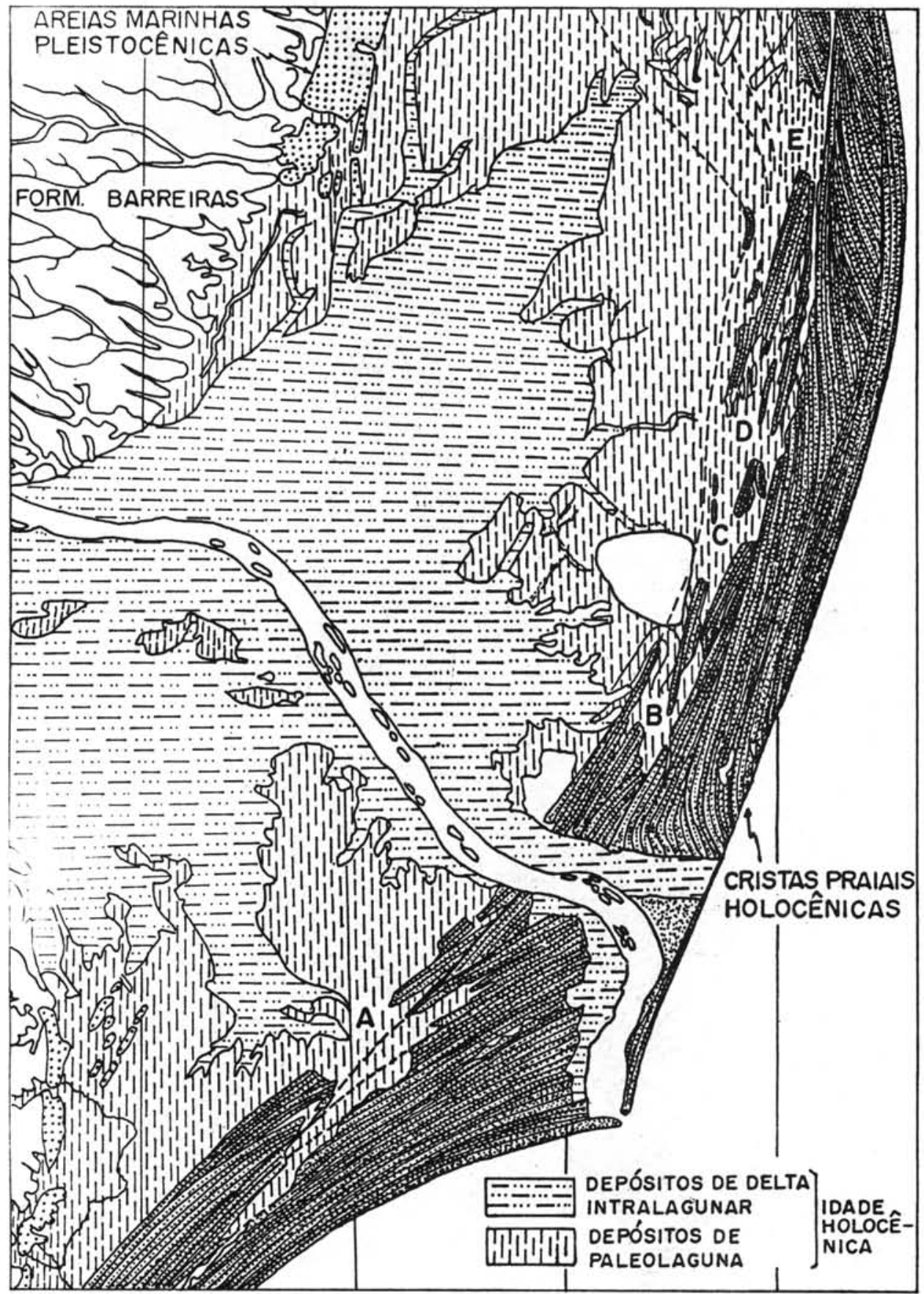

Figura 41 - Estádio C: Entre 4.200 e 3.900 anos A.P. - Configuração do delta intralagunar, com o traçado atual do canal do Rio. Doce, além das posiçōes das paleodesembocaduras sugeridas por descontinuidades nos alinhamentos das cristas praiais holocênicas (A, B, C, D, e E). 
(Fig. 42). O aporte arenoso do Rio Doce, juntamente com as areias fornecidas pelo abaixamento de nível relativo do mar, passou a contribuir na formação desta segunda zona de progradação.

Após a saída dos cinco distributários do Rio Doce teve início um perído de intensa progradação sob condições hidrodinâmicas criadas por ondas eficazes do setor sul (Fig. 43). Já foi visto que um fragmento de madeira amostrado nas cristas praiais ligadas à desembocadura $B$ havia sido datado de $3.940 \pm 200$ anos A.P. (Bah-964). Esta idade confirma que o abaixamento de nivel relativo do mar foi o fenômeno global que promoveu a saída contemporânea dos diversos braços do delta intralagunar ao mar. A ausência de discordância nos alinhamentos das cristas praiais formadas durante este período (Fig. 43), indica que não tenham sido produzidas mudanças notáveis nas condições hidrodinâmicas entre 4.200 e 3.900 anos A.P. e que, conseqüentemente, as ondas eficazes provieram sempre do setor sul.

Estádio D: Entre 3.900 e 3.600 anos A.P. - Uma reconstrução paleogeográfica permite colocar em evidência uma importante fase de erosão litorânea, particularmente dos depósitos arenosos que eram formados nas duas margens das cinco desembocaduras do Rio Doce (Fig. 44). Parece ser lógico relacionar esta erosão generalizada à "rápida" subida de nivel relativo do mar entre 3.900 e 3.600 anos A.P. Juntamente com esta fase erosiva ocorreu a reocupação de certas partes da antiga laguna. De fato, testemunho coletado em uma antiga laguna alongada da primeira geração de depósitos arenosos mostra a superposição de duas seqüências de sedimentos lagunares, separadas por sedimentos fluviais (Fig. 21). Uma datação por radiocarbono realizada sobre conchas provenientes de depósitos da fase lagunar mais nova indicou uma idade de $3.500 \pm 150$ anos A.P. Não se conhecem as condições hidrodinâmicas nem é possivel reconstruir o sentido segundo o qual as ondas eficazes atingiram a costa, pois não houve formação de cristas praiais neste período.

As cinco desembocaduras foram afogadas e, desta maneira, tornaram-se instáveis e foram abandonadas, sendo substituídas por uma desembocadura composta de um único canal. Os paleocanais distributários foram abandonados e as paleodesembocaduras foram fechadas pelas areias de deriva litorânea (Fig. 45).

Estádio E: Entre 3.600 e 2.700 anos A.P. - Esta etapa foi caracterizada por intensa progradação a partir de sedimentos fornecidos pela nova desembocadura. Porém, provavelmente a construção de uma ilha em frente à desembocadura deve ter propiciado a formação de dois braços e, então, originando-se duas saídas, uma orientada $E-W(G)$ e outra NW-SE $(H)$. A progradação a partir dessas duas novas desembocaduras prosseguiu normalmente sob condições hidrodinâmicas geradas pelas ondas eficazes provenientes do setor sul (Fig. 46). A ausência de qualquer discordância nos alinhamentos das cristas praiais preservadas fazem supcr que não tenham ocorrido mudanças nas condições hidrodinâmicas, isto é, inversão no sentido das ondas eficazes. 


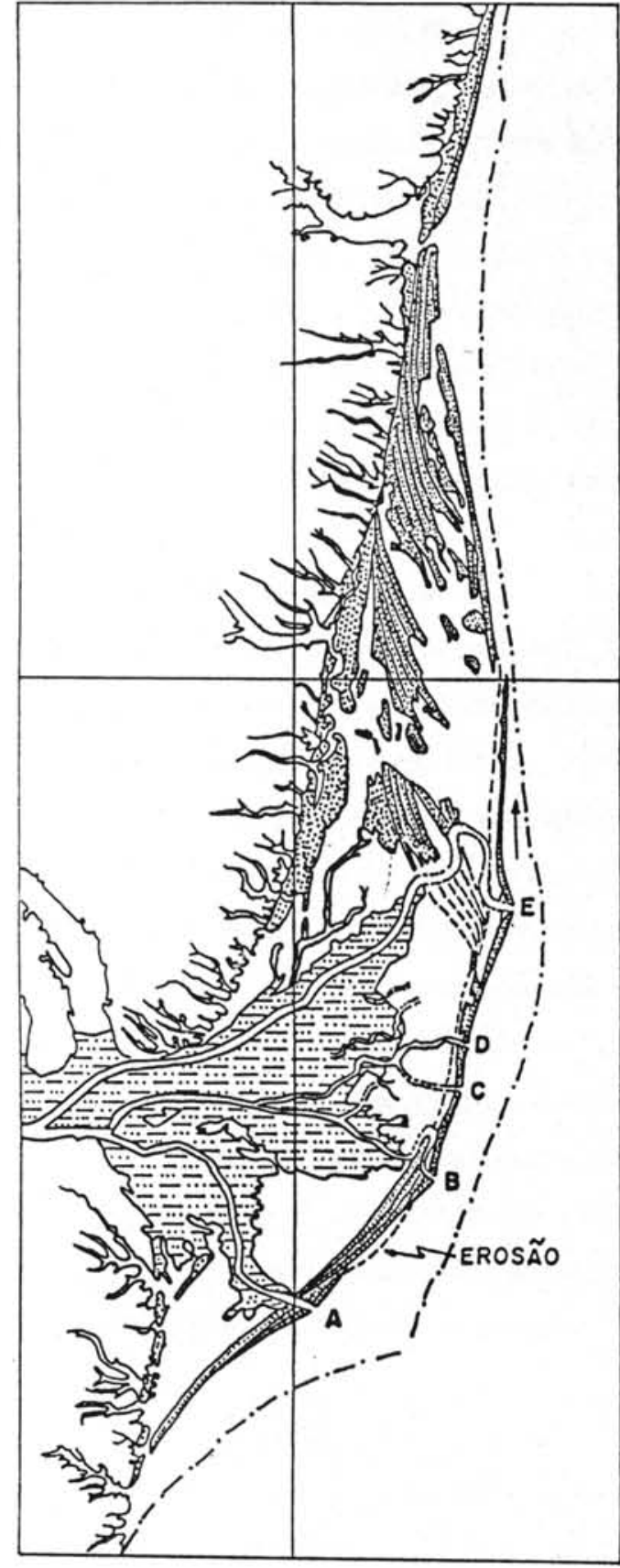

Figura 42 - Estádio C: Entre 4.200 e 3.900 anos A.P. - Saída direta para o oceano de cinco distributários do delta intralagunar do Rio Doce.

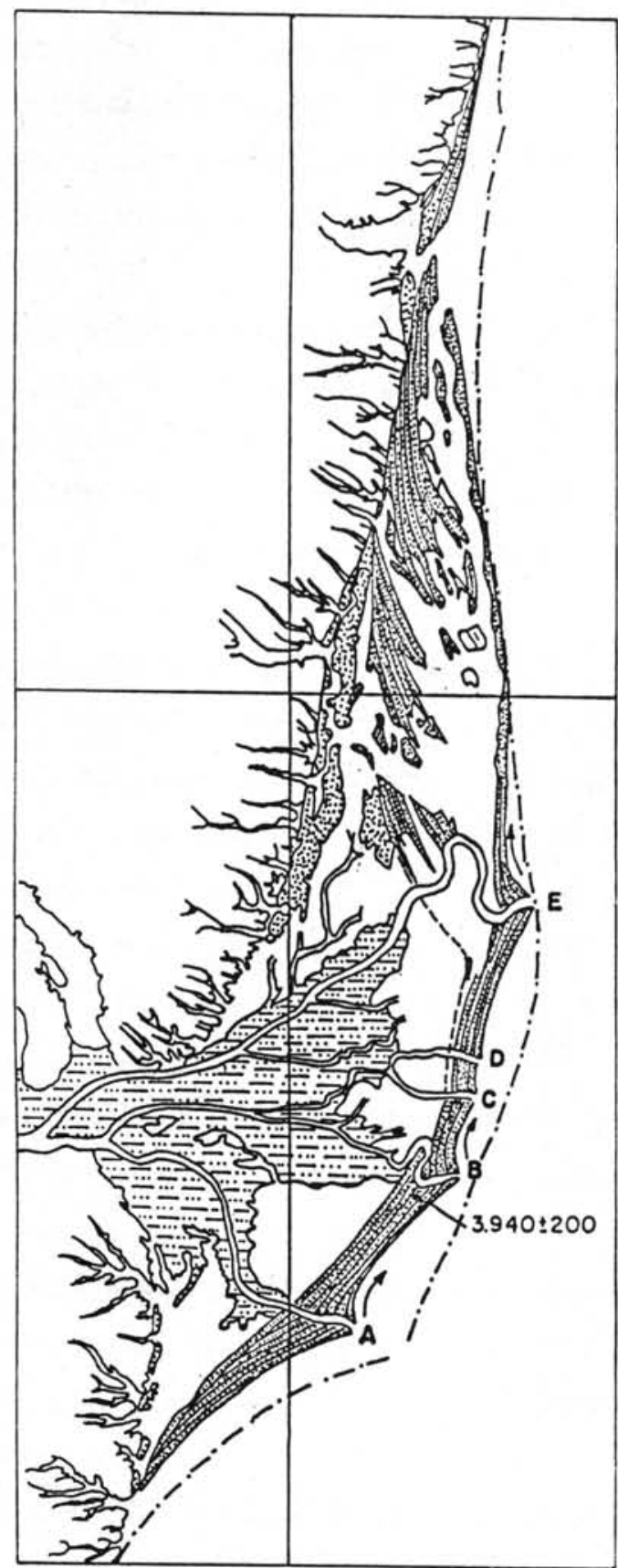

Figura 43 - Estádio C: Entre 4.200 e 3.900 anos A.P. - Progradação ao redor das novas desembocaduras. 


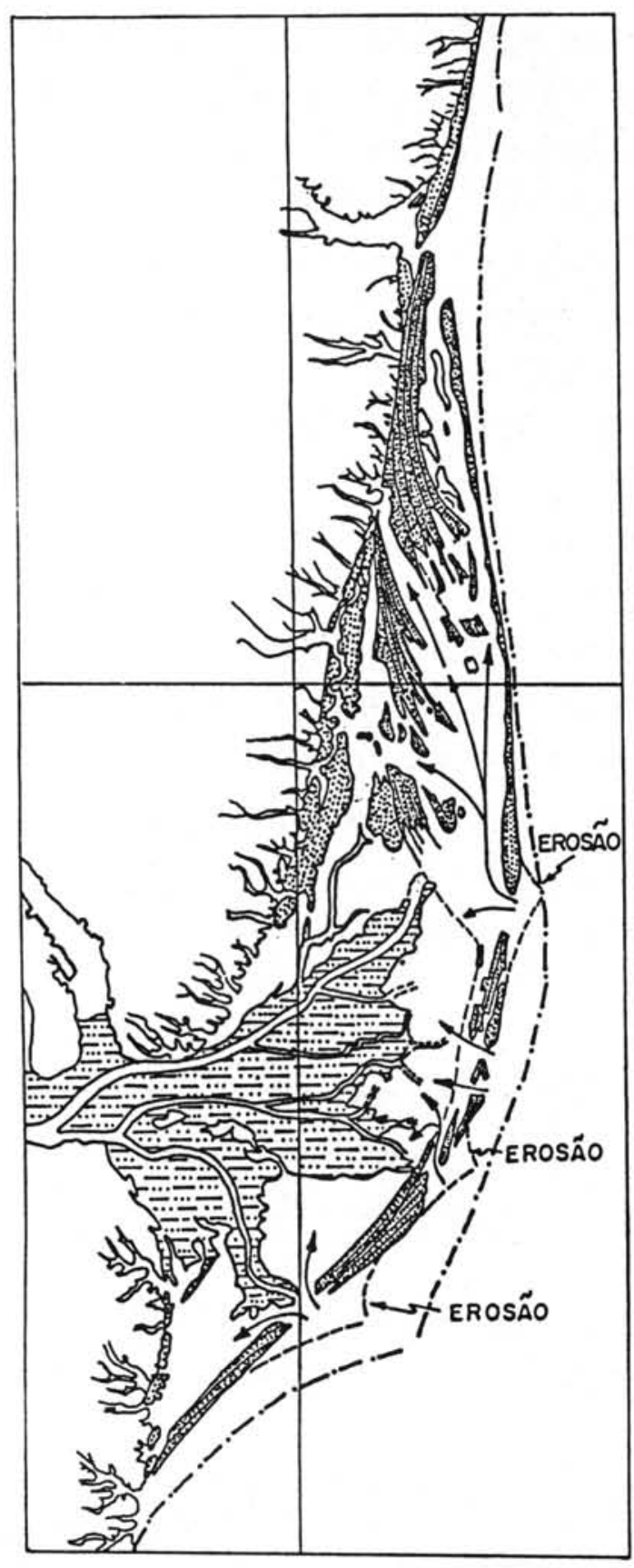

Figura 44 - Estádio D: Entre 3.900 e 3.600 anos A.P. - Submersão acompanhada de erosão ao redor das desembocaduras dos distributários.

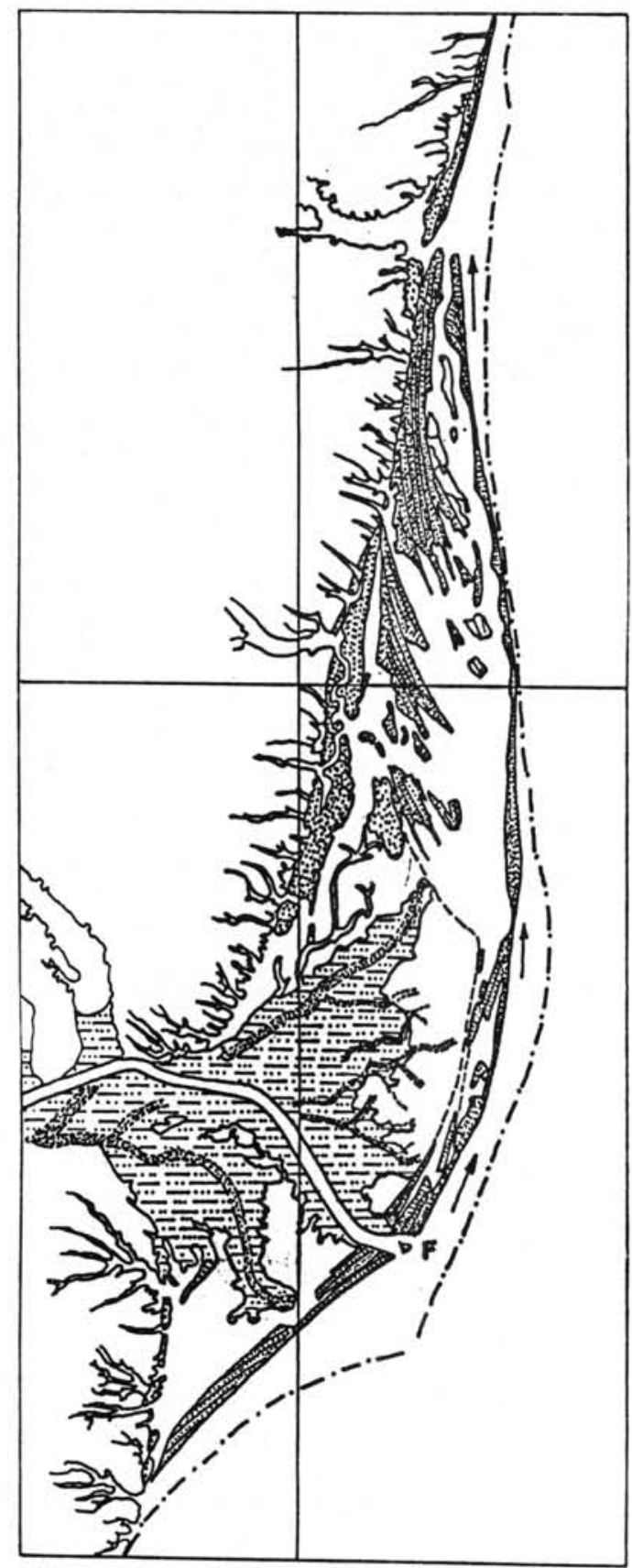

Figura 45 - Estádio D: Entre 3.900 e 3.600 anos A.P. - Abandono das cinco desembocaduras iniciais em beneficio de uma desembocadura única $(F)$. 
Estádio F: Entre 2.700 e 2.500 anos A.P. - Uma reconstrução paleogeográfica permitiu evidenciar uma fase de erosão generalizada afetando ambas as desembocaduras (Fig. 47). Porém, esta etapa erosiva parece ter sido menos importante do que aquela que se produziu no estádio $\mathrm{D}$ e as desembocaduras não foram abandonadas. Os efeitos erosivos parecem ter sido equilibrados pelos aportes arenosos do Rio Doce, que se encontravam muito mais concentrados do que no estádio D. Esta erosão não pode ser atribuída à variação hidrodinâmica em conseqüência da inversão no sentido das ondas eficazes. De fato, neste caso, como será visto mais adiante, só as margens da desembocadura $\mathrm{H}$ foram erodidas, pois a desembocadura $\mathrm{G}$ se encontrava protegida da ação de ondas provenientes de NE. Parece mais lógico relacionar esta fase de erosão generalizada à subida do nivel relativo do mar que se processou entre 2.700 e 2.500 anos A.P.

Estádio G: 2.500 anos A.P. até hoje - Algumas discordâncias nos alinhamentos das cristas praiais permitem, como no caso da primeira zona de sedimentação, evidenciar diversas fases de construção e de erosão correspondentes a condições hidrodinâmicas diferentes.

Subestádio G-1: Primeira fase de construção (Fig. 48) - Prosseguimento da progradação de ambas as margens das desembocaduras G e H sob condições hidrodinâmicas geradas por ondas eficazes provenientes do setor sul. As arelas fornecidas pelo Rio Doce $\theta$ depositadas em frente à desembocadura $\mathrm{H}$ foram transportadas para o norte. Por outro lado, as areias sedimentadas defronte à desembocadura G, em conseqüência da diferença de orientação, foram transportadas para o norte e para o sul.

Subestádio G-2: Primeira fase de erosão (Fig. 49) - Uma reconstrução paleogeográfica permitiu evidenciar erosão localizada na desembocadura norte $(\mathbf{H})$. Este fato deve ter resultado de mudança hidrodinâmica local em função de inversão no sentido das ondas eficazes. De fato, nessas condições, a desembocadura norte $(H)$ encontrava-se em desequillbrio enquanto que a sul (G) estava protegida da ação das ondas de NE.

Subestádio G-3: Segunda fase de construção (Fig. 50) - Continuação da progradação para o norte a partir da desembocadura $\mathrm{H}$ e para sul e norte a partir de $\mathrm{G}$, sob condições hidrodinâmicas geradas pelas ondas èficazes do setor sul.

Subestádio G-4: Segunda fase de erosão (Fig. 51) - Uma reconstrução paleogeográfica possibilitou mostrar a ocorrência de erosão localizada na desembocadura norte $(H)$. Este fato indicaria uma modificação do regime hidrodinâmico local que teria passado a ser caracterizada pelas ondas eficazes do setor norte.

Subestádio G-5: Terceira fase de construção (Fig. 52) - Retomada do processo de progradação para o norte a partir da desembocadura $\mathrm{H}$ e para o sul e norte a partir da desembocadura G. Rumo ao norte, a sedimentação teria sido sobretudo importante na concavidade formada na costa 


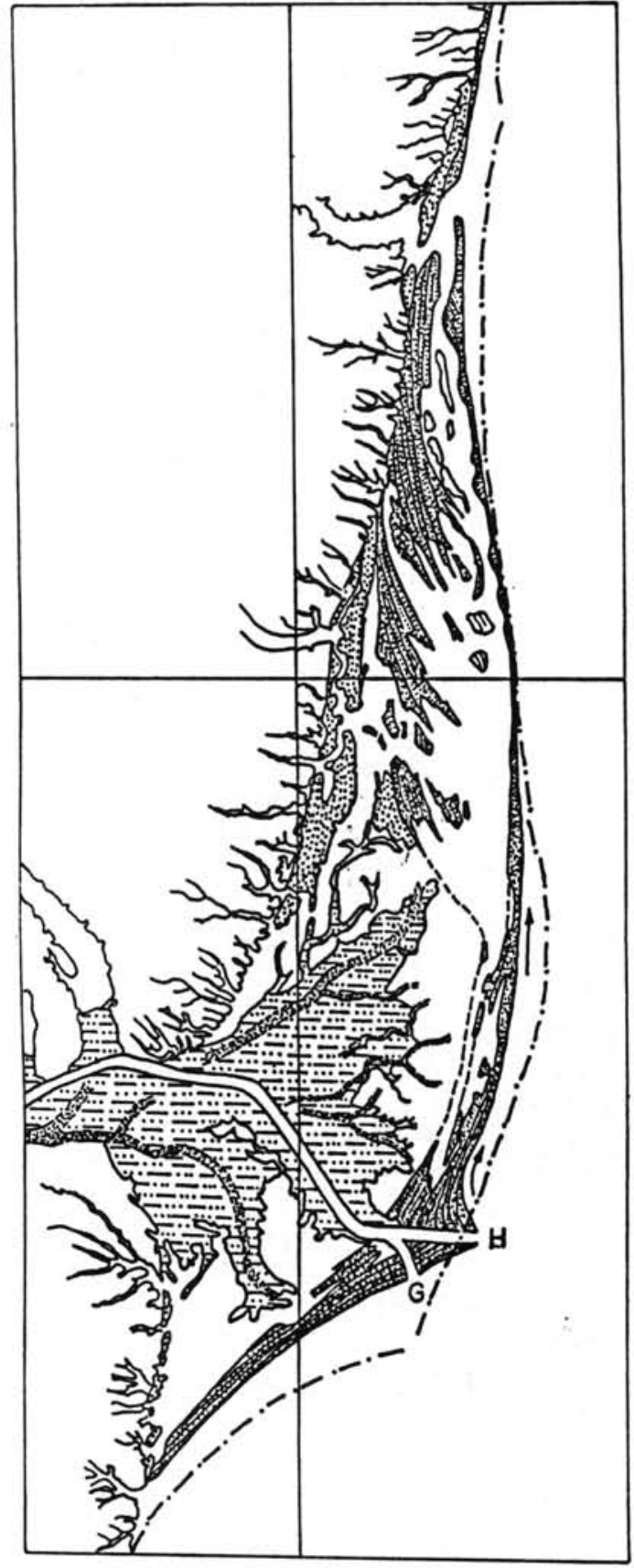

Figura 46 - Estádio E: Entre 3.600 e 2.700 anso A.P. - Progradação acompanhando a formação de duas novas desembocaduras (G e H).

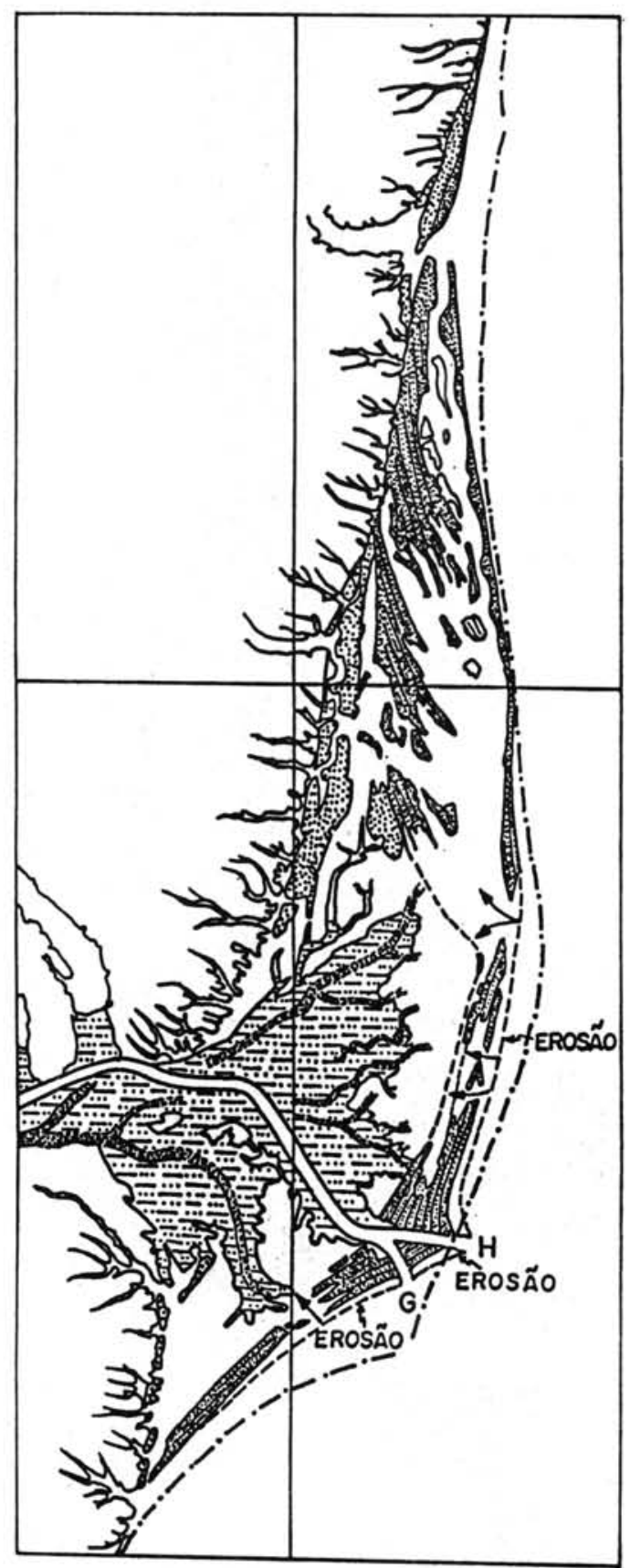

Figura 47 - Estádio F: Entre 2.700 e 2.500 anos A.P. - Época de erosão generalizada devida à subida do nível relativo do mar. 


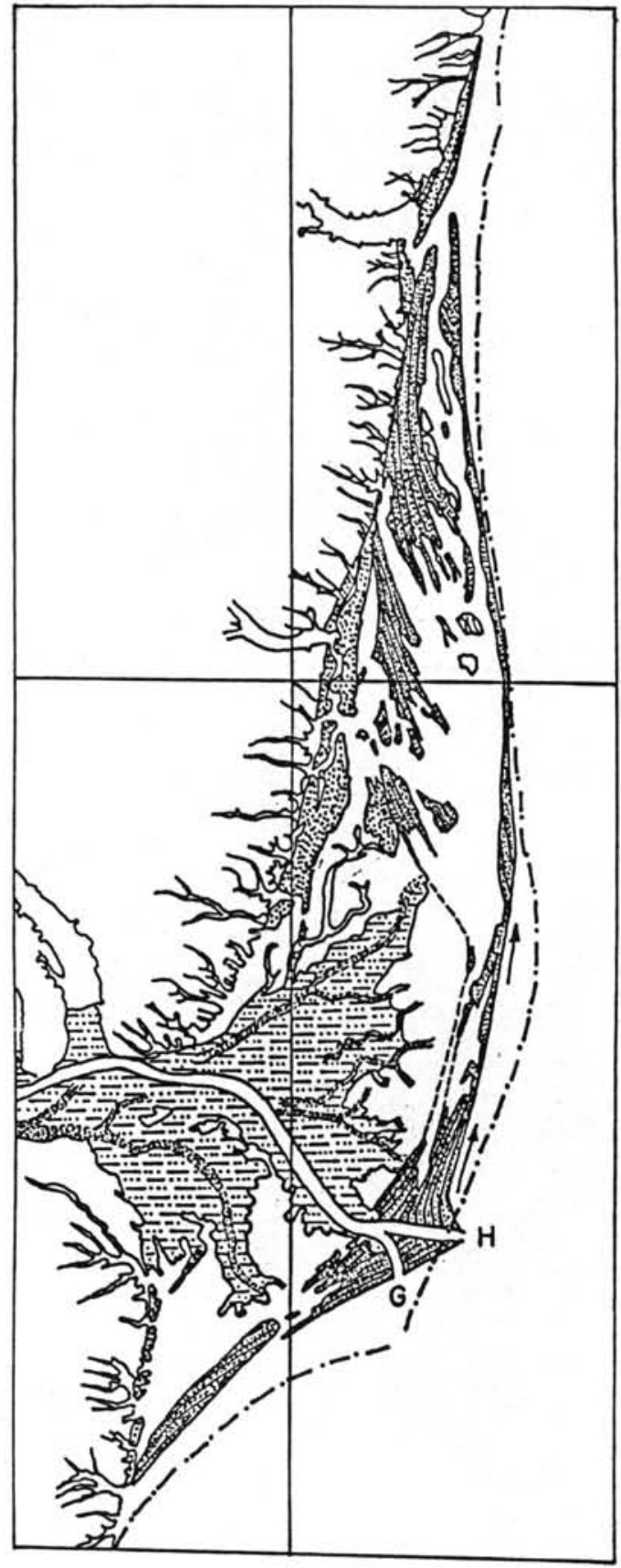

Figura 48 - Subestádio G-1: Primeira fase de construção do intervalo de tempo correspondente a 2.500 - 0 anos A.P.

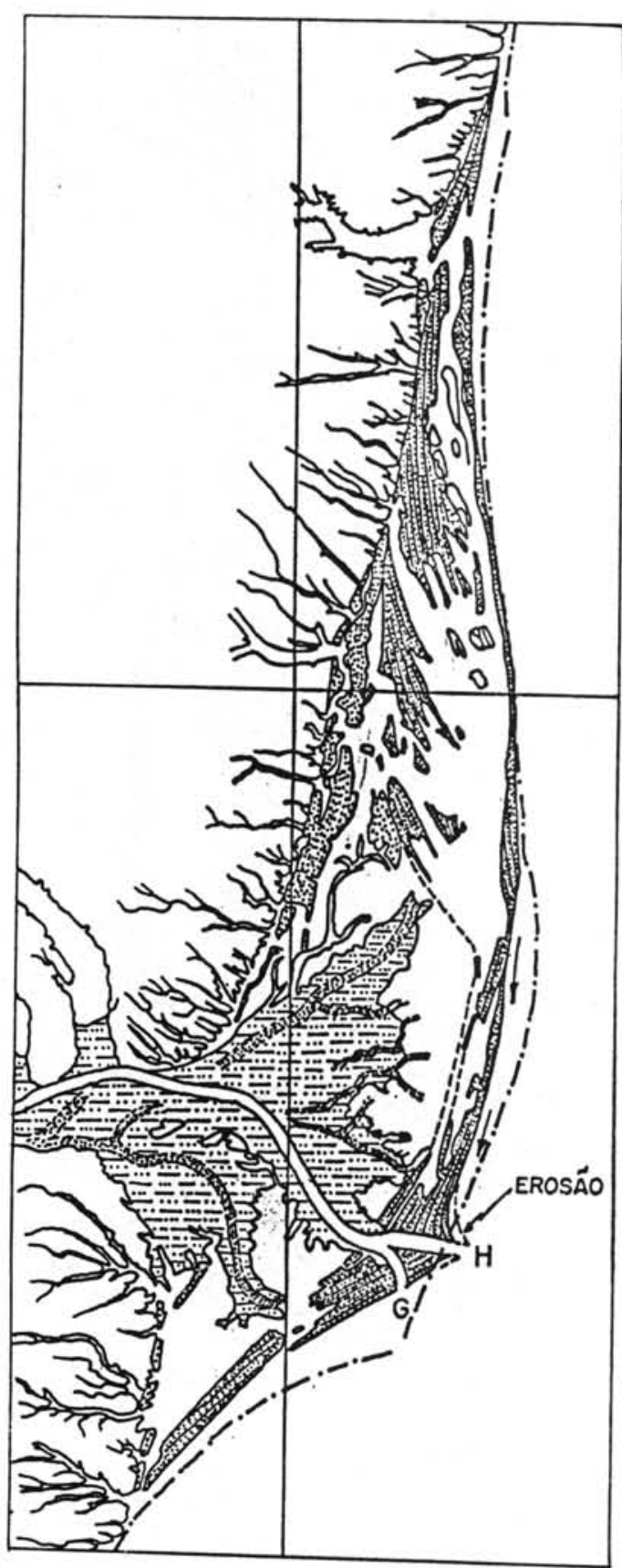

Figura 49 - Subestádio G-2: Primeira fase de erosão do intervalo de tempo correspondente a 2.500 - 0 anos A.P. 


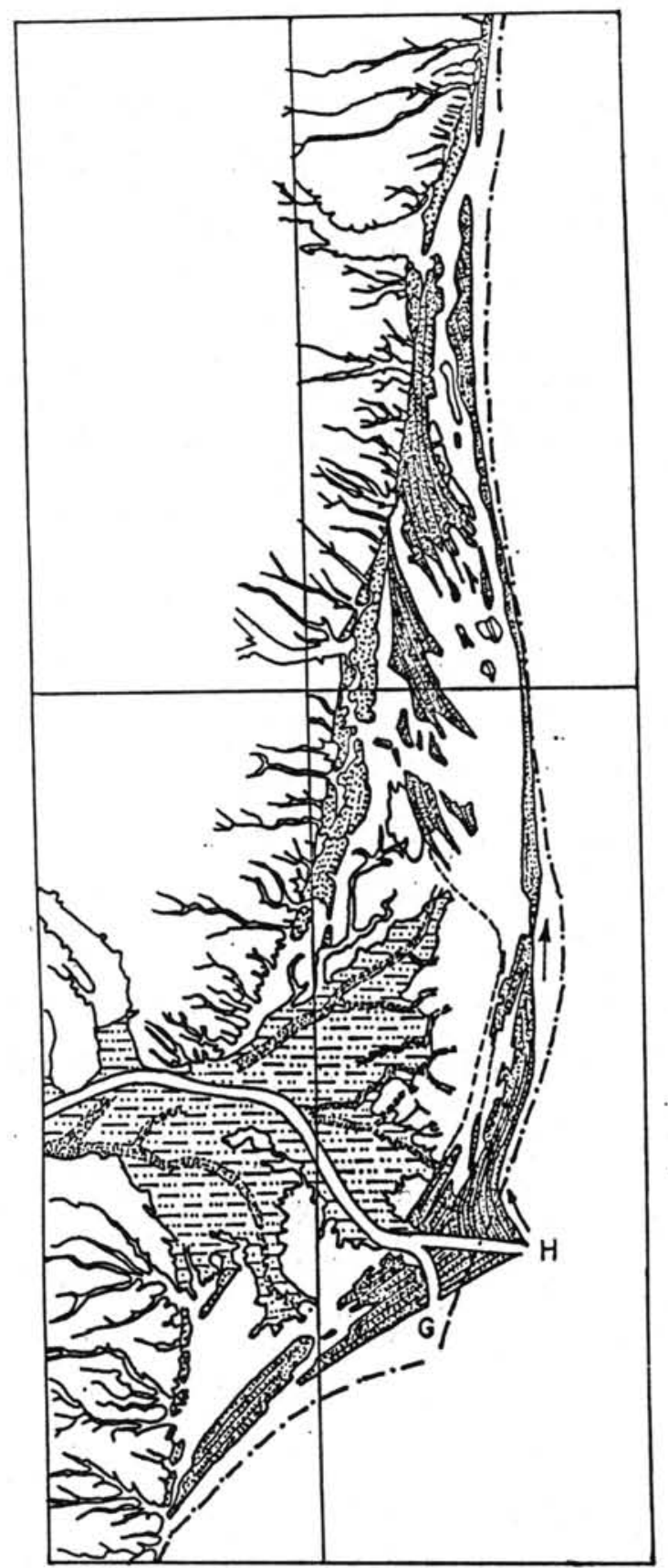

Figura 50 - Subestádio G-3: Segunda fase de construçāo do intervalo de tempo correspondente a $2.500-0$ anos A.P.

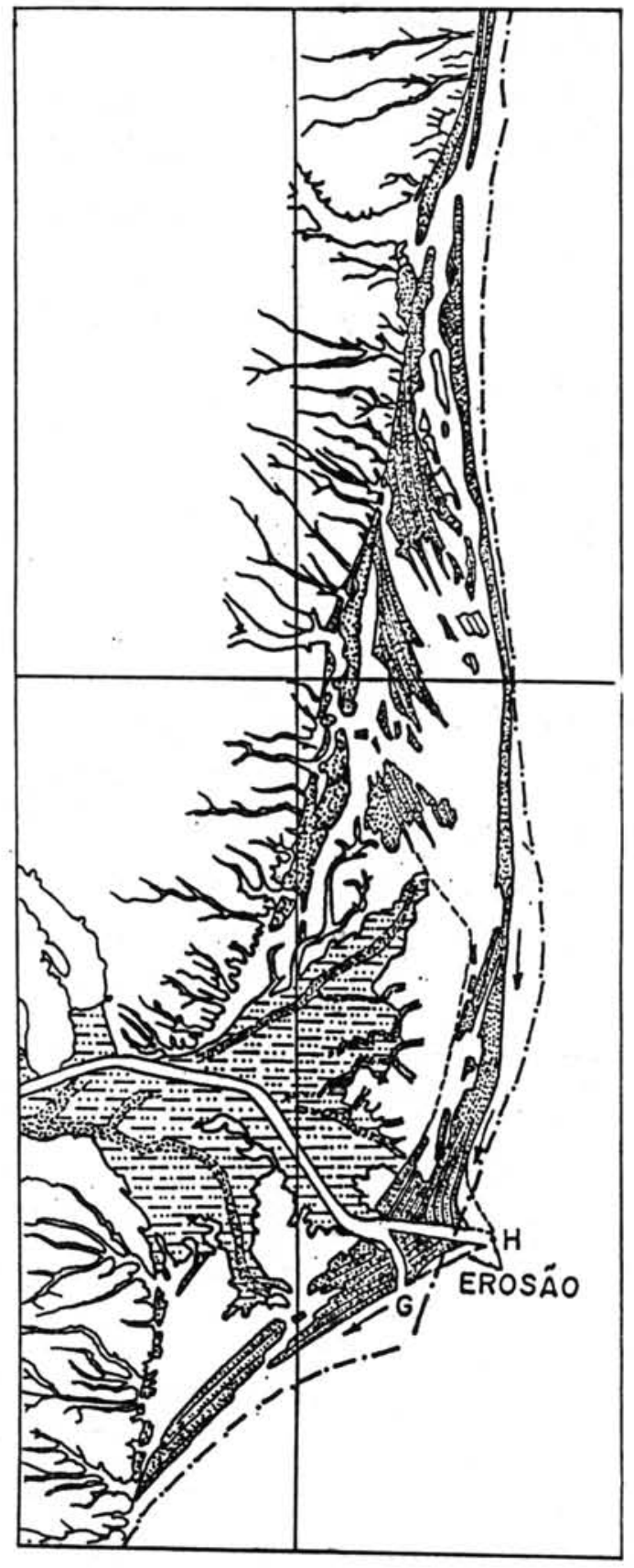

Figura 51 - Subestádio G-4: Segunda fase de erosão do intervalo de tempo correspondente a $2.500-0$ anos A.P. 
a altura da antiga desembocadura E. Esta fase traduziria condições hidrodinâmicas geradas pelas ondas eficazes do setor sul.

Subestádio G-6: Terceira fase de erosão (Fig. 53) - Uma reconstrução paleogeográfica permitiu evidenciar nova fase de erosão localizada. Como nos subestádios G-2 e G-4, este fenômeno deve ter afetado os depósitos da desembocadura $H$, porém não os da desembocadura G. Além disso, a linha de costa que sofreu importante progradação na altura da antiga desembocadura $E$, no subestádio precedente, foi igualmente erodida pois encontrava-se em desequilíbrio com as condições hidrodinâmicas geradas pelas ondas do setor norte.

Subestádio G-7: Quarta fase de construção (Fig. 54) - Reinício da progradação, como foi verificada nos subestádios G-1, G-3 e G-5 traduzindo condições hidrodinâmicas geradas por ondas eficazes provenientes do setor sul.

Subestádio G-8: Fechamento da desembocadura norte (Fig. 55) - Reconstrução paleogeográfica de detalhe permitiu mostrar uma forte erosão em ambas as margens da desembocadura norte $(H)$. Porém, diferentemente do que ocorreu no subestádio $G-6$, os depósitos formados ao norte da desembocadura $\mathrm{H}$ e que normalmente ficavam em desequillbrio sob condições hidrodinâmicas geradas por ondas de NE, não foram erodidos. Portanto, não deve ter sido uma modificação no sentido das ondas que provocou a erosão da desembocadura H. Atualmente, o Rio Doce possui só uma desembocadura ativa e a ocorrência de cristas praiais entre as desembocaduras $\mathrm{G}$ e $\mathrm{H}$ mostra que não deve ter ocorrido uma migração gradual da desembocadura de $\mathrm{H}$ para $\mathrm{G}$, isto é, a desembocadura $\mathrm{H}$ deve ter ficado inativa em tempo bem recente. Esta, não sendo mais alimentada de areia pelo Rio Doce, ficou em desequilibrio devendo ter sido atacada por erosão sob condições hidrodinâmicas geradas pelas ondas eficazes do setor sul. Este evento poderia explicar a sedimentação acelerada na área de desembocadura do Rio São Mateus, que pode ter funcionado como um "molhe" na retenção de sedimentos erodidos ao sul, que estavam em trânsito ao longo da costa.

Subestádio G-9: Situação subatual e atual - Em função da orientação praticamente norte-sul da desembocadura, as areias transportadas pelo Rio Doce passaram a ser depositadas em ambos os lados da foz (Fig. 55). Esta sedimentação recente aparece bastante claramente no terreno e sobre as fotografias aéreas. As condições hidrodinâmicas de ondas eficazes devem ter sido geradas pelo setor sul.

c) Considerações gerais

Tendo em vista as reconstruções paleogeográficas até aqui realizadas, parece que a condição essencial para que um depósito sedimentar situado na foz de um rio seja considerado um delta, isto é, formado pelo aporte de corrente aquosa não foi inteiramente satisfeita no caso da planície 


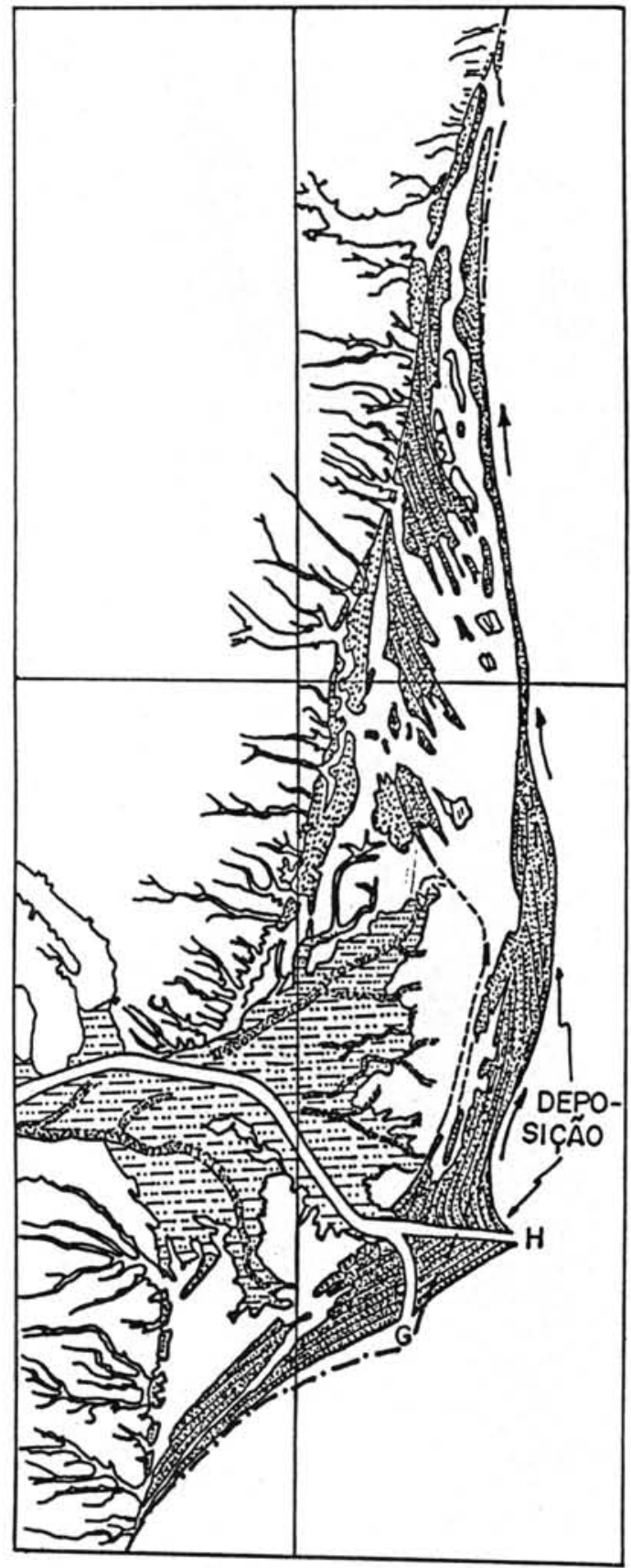

Figura 52 - Subestádio G-5: Terceira fase de construçăo do intervalo de tempo correspondente a $2.500-0$ anos A.P.

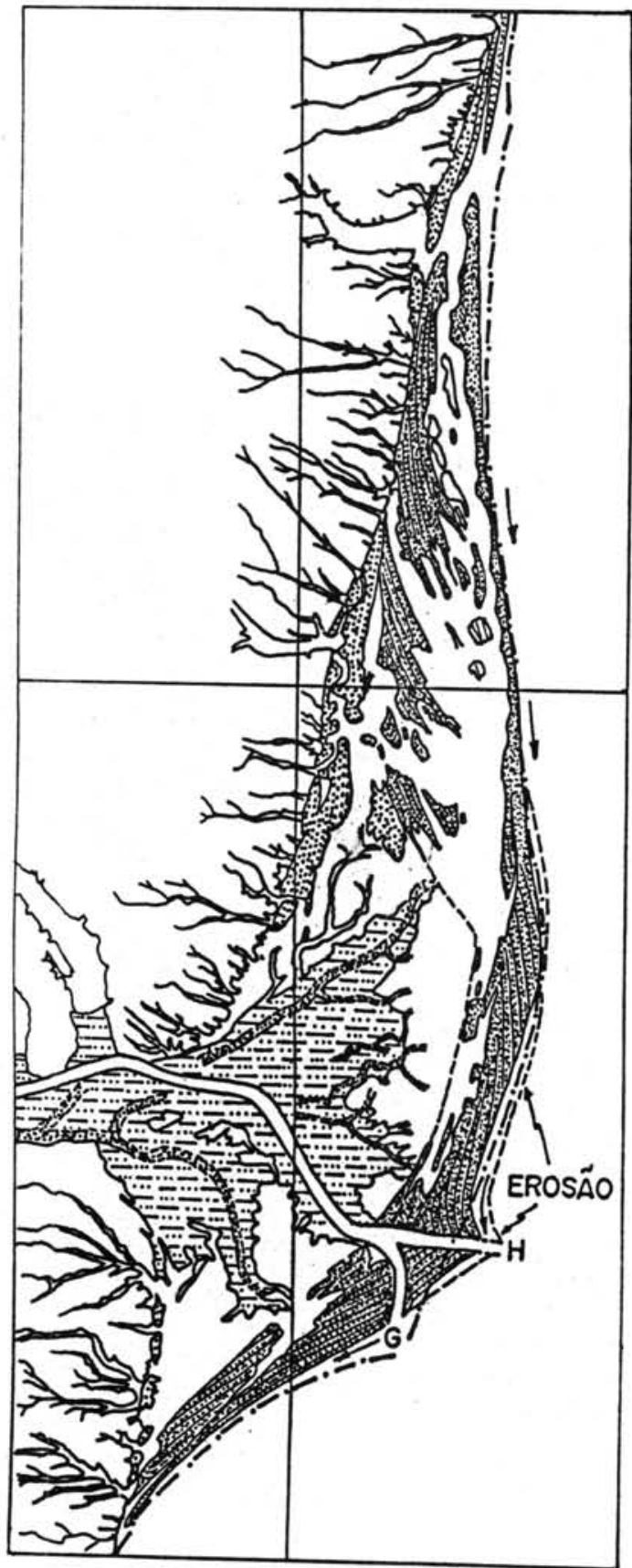

Figura 53 - Subestádio G-6: Terceira fase de erosão do intervalo de tempo correspondente a $2.500-0$ anos A.P. 


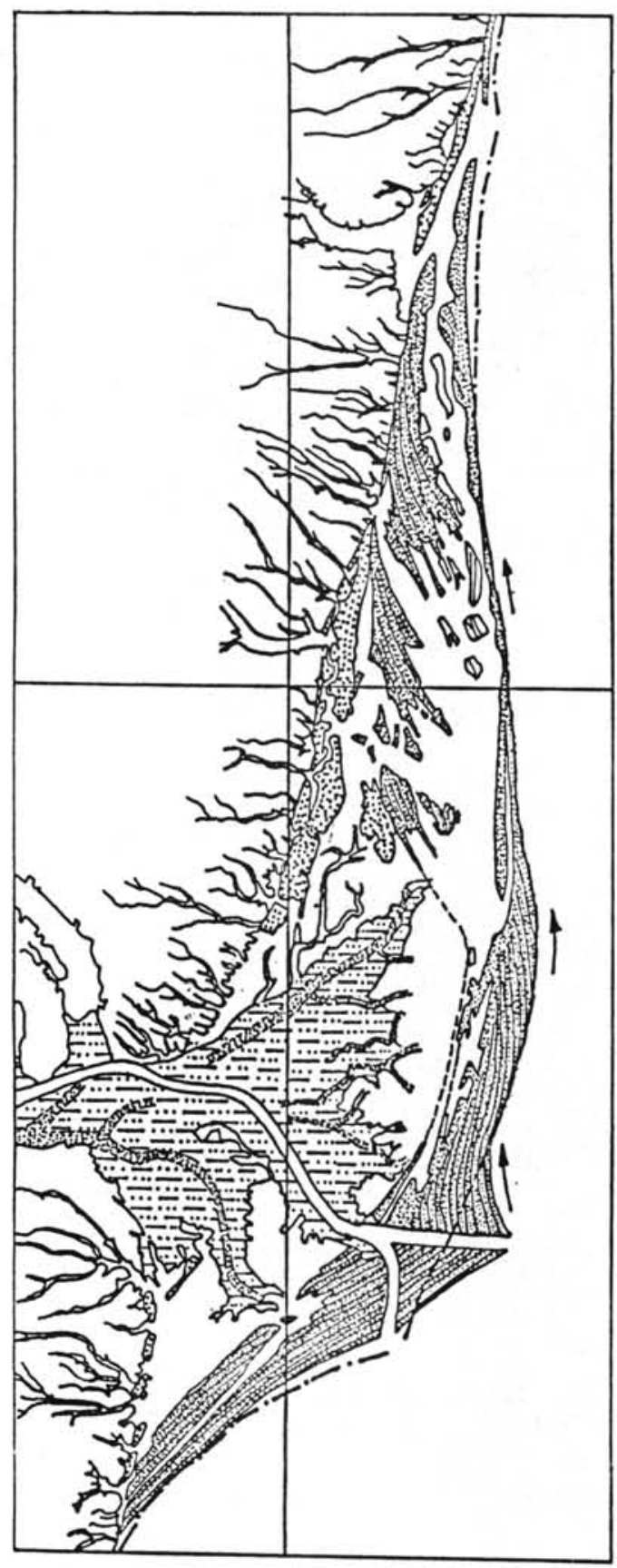

Figura 54 - Subestádio G-7: Quarta fase de construção do intervalo de tempo correspondente a $2.500-0$ anos A.P.

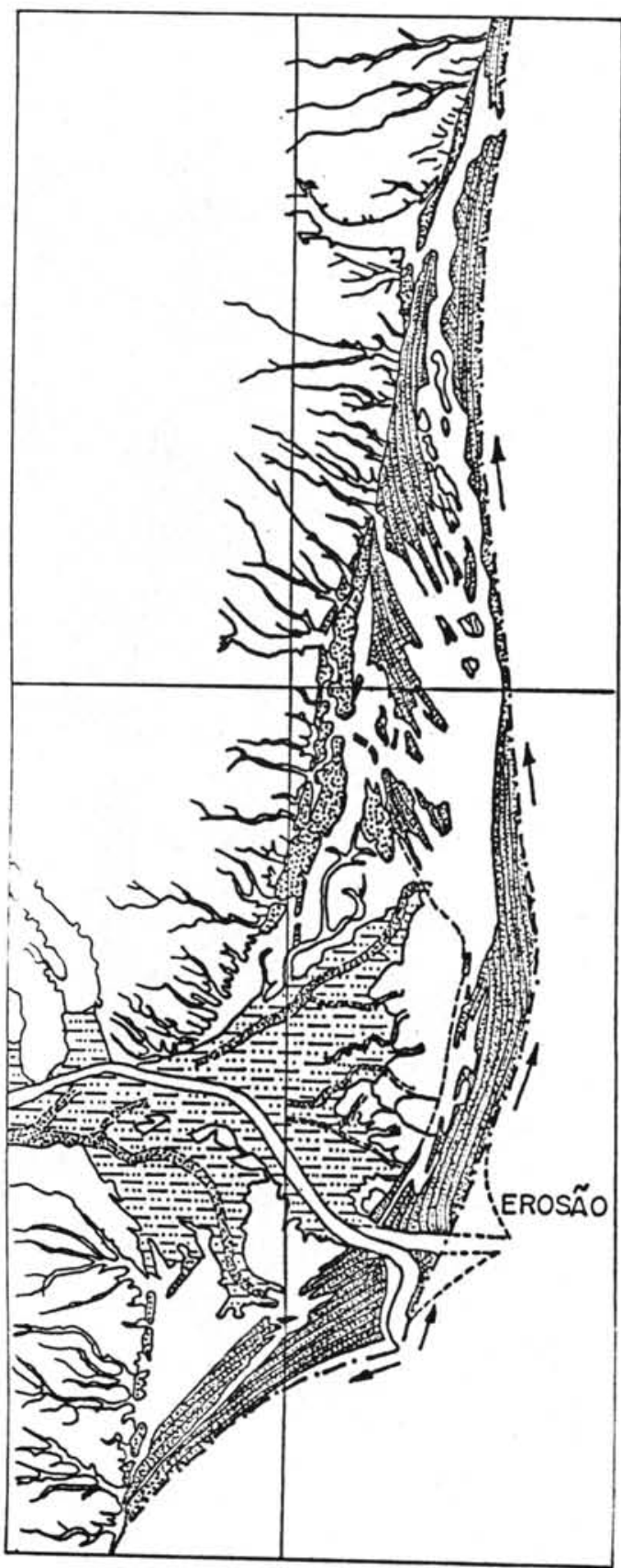

Figura 55 - Subestádio G-8 e G-9: Abandono da desembocadura norte $(H)$ e erosão das zonas em desequilibrio hidrodinâmico. 
costeira do Rio Doce. De fato, foi visto que durante longo período de tempo os aportes do Rio Doce foram trapeados em uma extensa laguna onde fol edificado um enorme delta intralagunar apresentando todas as características de um delta dominado por processos fluviais. Então, eles não puderam contribuir na construção da primeira geração de terraços arenosos holocênicos que, portanto, não podem ser considerados como depósitos de frente deltaica de um delta dominado por ondas. Foi somente a partir do momento em que o Rio Doce passou a fluir diretamente ao oceano é que os seus aportes sedimentares puderam contribuir, paralelamente aos materiais de deriva litorânea, na construção da segunda geração de terraços arenosos holocênicos. Porém, ainda fol demonstrado pelas reconstruções paleogeográficas sucessivas que as areias transportadas pelo Rio Doce foram depositadas principalmente ao norte das desembocaduras, não tendo então contribuído para a construção da totalidade da segunda geração de terraços arenosos holocênicos. Foi somente a partir do subestádio G-9, em função da orientação norte-sul do curso inferior do Rlo Doce, que as areias depositadas ao largo da única desembocadura passaram a ser distribuídas nas duas margens, como acontece nos típicos deltas dominados por ondas. Porém, este intervalo de tempo corresponde apenas a parte infima da história da planície costeira do Rio Doce, de modo que ela não deveria ser considerada como um "clássico delta dominado por ondas", como têm sido feito freqüentemente até este momento.

\subsubsection{Planície costeira do Rio Paraíba do Sul (RJ)}

\subsubsection{Aspectos gerais}

A planície costeira do Rio Paraíba do Sul está situada na metade norte do Estado do Rio de Janeiro, cobrindo uma superfície de aproximadamente $3.000 \mathrm{~km}^{2}$, com um comprimento norte-sul de 120 km e uma largura máxima de 60 km (Fig. 56).

Como no caso da foz do Rio Doce, a região da desembocadura do Rio Parafba do Sul também está sujeita a chuvas de verão com estação seca durante o outono e inverno (W da classificação de Köppen), mas esta estação seca ainda pode ser perturbada por precipitações frontais de descargas pluviais devidas ao ar polar. Os ventos predominantes provém de ENE e SSE, sendo os últimos relacionados a passagens de frentes frias que periodicamente atingem a região no outono $\theta$ inverno.

Embora não se disponha de informações estatisticamente representativas sobre as ondas, todas as evidências indicam a existência de ondas provenientes de ENE e SSE, de modo semelhante à foz do Rio Doce. O Fenômeno El Niño provoca os mesmos tipos de perturbações no regime dos ventos e das ondas que na região da desembocadura do Rio Doce, porém, as intensidades do fenômeno nem sempre são semelhantes. 


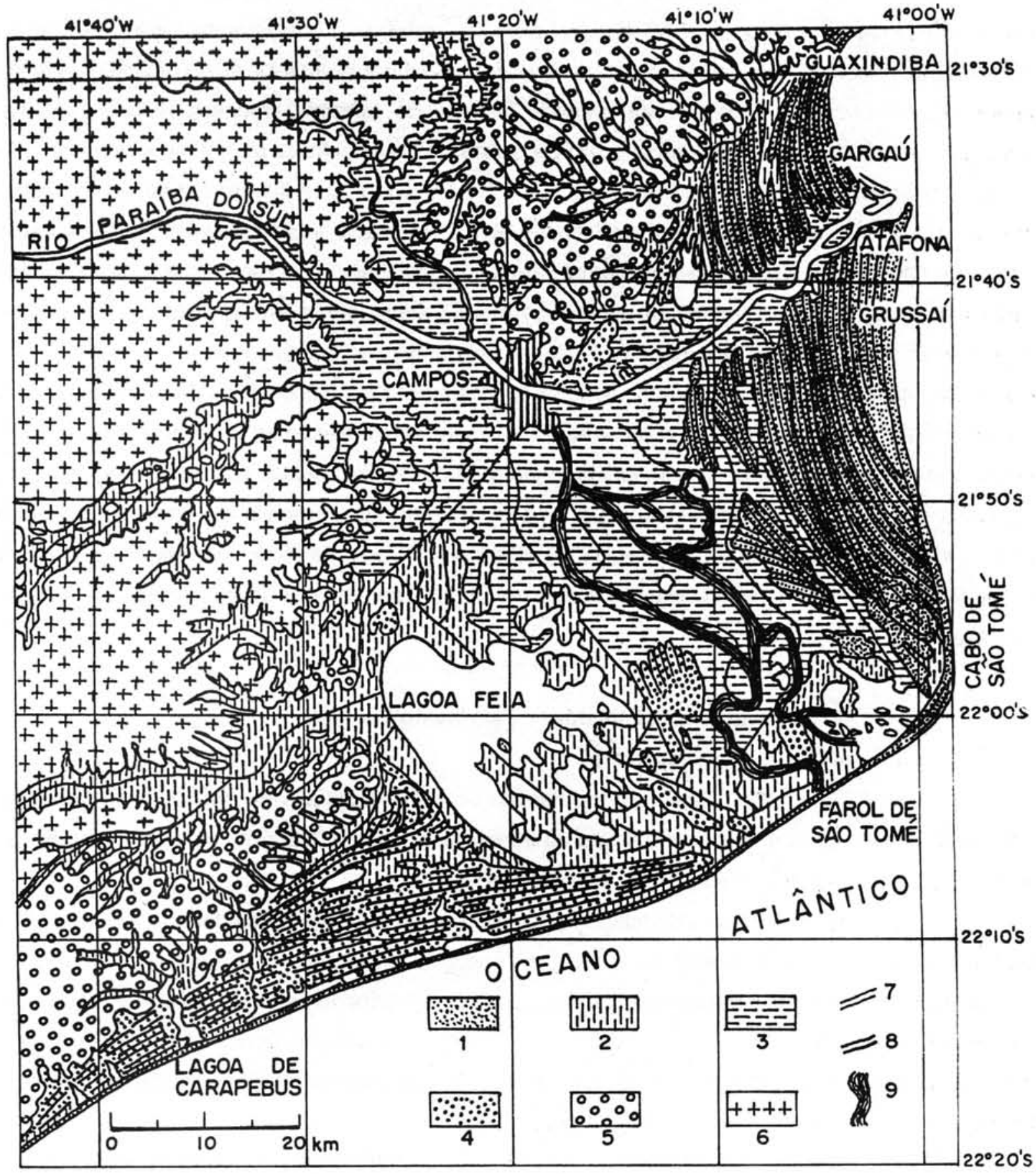

Figura 56 - Mapa geológico esquemático da planície costeira do Rio Paraíba do Sul (ES): (1) terraço marinho holocênico, (2) sedimentos lagunares, (3) sedimentos fluviais (delta intralagunar), (4) terraço pleistocênico, (5) sedimentos continentais terciários (Formação Barreiras), (6) embasamento cristalino pré-cambriano. (7) alinhamentos de cristas praiais holocênicas; (8) alinhamentos de cristas praiais pleistocênicas e (9) paleocanais fluviais. 
O Rio Paraíba do Sul nasce na região entre as serras do Mar e da Bocaina, resultando da junção dos rios Paraibuna e Paraitinga no Estado de São Paulo. A extensão do rio é de cerca de $950 \mathrm{~km}$ e a sua bacia hidrográfica cobre uma área de aproximadamente $45.000 \mathrm{~km}^{2}$. Sua descarga média é de $800 \mathrm{~m}^{3} / \mathrm{s}$ em Campos (RJ), mas as variações anuais podem ser muito acentuadas. Desta maneira, por exemplo, em 1937 a descarga média anual fol de $1.785 \mathrm{~m}^{3} / \mathrm{s}$, enquanto que em 1954 foi de $341 \mathrm{~m}^{3} / \mathrm{s}$ (ARAÚJO et al., 1975).

\subsubsection{Geomorfologia}

De maneira semelhante à planície costeira do Rio Doce, esta planície também é composta por três províncias geomorfológicas, individualizadas tanto pelo relevo como pela drenagem, que são as seguintes: a) Região Serrana, b) Tabuleiros Terciários e c) Planície Quaternária (Fig. 56).

a) Região Serrana - Esta unidade coincide com a área de ocorrência das rochas cristalinas pré-cambrianas. Apresenta-se com padrões fisiográficos distintos, sendo o primeiro constituído por morros pontiagudos e de encostas íngremes e o segundo caracterizado por um relevo mais suave com morros em forma de meia-laranja. Enquanto no primeiro tipo a drenagem é retangular, com os rios principais seguindo a xistosidade e os secundários os sistemas de fraturas, no segundo a rede hidrográfica é principalmente dendrítica.

b) Tabuleiros Terciários - Constituem uma superfície homoclinal com suave mergulho rumo ao mar, sulcada por drenagem subparalela. Acham-se bem desenvolvidos na porção norte, onde atingem altitudes de até cerca de $50 \mathrm{~m}$, embora em Campos não ultrapasse de $14 \mathrm{~m}$. $\mathrm{Na}$ porção sul, formam uma faixa estreita e estão ausentes na porção central. No contato entre os Tabuleiros Terciários e a Planície Quaternária, encontram-se linhas de escarpas. Na zona dos Tabuleiros Terciários ocorrem lagoas encravadas em paleovales escavados sobre a Formação Barreiras, geradas através da barragem por sedimentos fluviais.

c) Planície Quaternária - Estende-se desde a cidade de Macaé ao sul até a localidade de Guaxindiba ao norte. Possui uma superfície bastante plana, com altitude máxima de aproximadamente $12 \mathrm{~m}$ e inclina-se suavemente rumo ao oceano. Esta área foi intensamente saneada e ocupada pelo homem. Uma extensa rede de canais artificiais de drenagem rebaixou o lençol freático e ressecou muitas lagoas e pântanos. Diques marginais artificiais foram construídos ao longo do Rio Paraíba do Sul para impedir o seu transbordamento sobre grande parte da Planície Quaternária.

Muitos tipos diferentes de lagoas e lagunas são encontrados sobre esta planície. Algumas lagoas, como a de Carapebus, Cabiúnas e Paulista foram formadas através da barragem de zonas baixas no interior de sedimentos pleistocênicos marinhos por sedimentos holocênicos, também de origem marinha, enquanto que outras acham-se situadas entre cristas praiais holocênicas, como as 
de Mololô, da Flecha, das Ostras e Salgada, estando somente a última ainda com água. A Lagoa Feia, que ocupa uma boa parte da porção central da Planície Quaternária, representa um testemunho de uma grande paleolaguna que existia entre 6.000 e 4.000 anos A.P., onde o Rio Paraíba do Sul construiu um delta intralagunar.

\subsubsection{Depósitos Quaternários (Fig. 56)}

a) Areias marinhas pleistocênicas - Essas areias formam terraços e ocorrem em uma faixa contínua de cerca de $60 \mathrm{~km}$ de comprimento e $10 \mathrm{~km}$ de largura máxima, ocupando praticamente toda a porção sul da planície costeira. Os alinhamentos de antigas cristas praiais são perfeitamente visíveis sobre as fotografias aéreas, sendo as partes baixas entre as cristas ocupadas por zonas pantanosas.

As altitudes de topo desses terraços pleistocênicos são anormalmente baixas nesta área em confronto com as de outras regiões ao longo da costa brasileira. Deste modo, na margem da Lagoa de Carapebus, em contato com a Formação Barreiras, o topo do terraço está situado apenas cerca de $3 \mathrm{~m}$ acima do nivel da lagoa. Nas proximidades da praia atual da lagoa, o topo deste terraço apresenta-se apenas cerca de $1 \mathrm{~m}$ acima do nivel atual da lagoa. Portanto, neste local, o topo da barreira holocênica que fecha a Lagoa de Carapebus, encontra-se acima do terraço pleistocênico. Na extremidade sul da planície costeira, a pós-praia atual apresenta-se acima do terraço pleistocênico e está avançando sobre o mesmo. Neste local, a areia pleistocênica é branca e acastanhada, enquanto que a areia atual é amarelada.

Na porção norte da planície costeira são encontrados testemunhos de terraços pleistocênicos que formam uma faixa mais ou menos regular de cerca de $5 \mathrm{~km}$ ao sopé das escarpas dos sedimentos da Formação Barreiras.

b) Areias marinhas holocênicas - Estas areias são encontradas predominantemente de um lado e do outro do Rio Paraíba do Sul, nas proximidades da sua desembocadura atual, onde se distribuem segundo uma área triangular com cerca de $60 \mathrm{~km}$ de base e $20 \mathrm{~km}$ de altura. Alinhamentos muito nítidos de cristas praiais, em sua superfície, permitem diferenciá-las facilmente dos terraços pleistocênicos quando observados em fotografias aéreas (MARTIN et al., 1981b). Nas cristas praiais da margem direita do rio, nota-se a presença de grandes discordâncias nos alinhamentos.

Amostras de conchas de moluscos, provenientes das cristas praiais, foram datadas por radiocarbono tendo sido obtidas as seguintes idades: 
Número da amostra

PS-42

PS-41

PS-35

PS-33

PS-32

PS-34
Idade radiocarbono (anos A.P.)

$4.390 \pm 200$

$4.380 \pm 200$

$3.850 \pm 200$

$2.110 \pm 200$

$1.980 \pm 190$

$1.070 \pm 160$
Referência de laboratório

Bah-1094

Bah-1093

Bah-1102

Bah-1100

Bah-1099

Bah-1101

Na porção sul da planície costeira, de São Tomé até Macaé, os depósitos holocênicos de origem marinha são muito escassos, limitando-se a uma estreita faixa junto à linha praial atual.

c) Depósitos lagunares - Na região de São Tomé e ao redor da Lagoa Feia, que constituem a parte central da planície, existe uma extensa zona de sedimentos lagunares arenoargilosos contendo matéria orgânica e muitas conchas de moluscos. Algumas dessas conchas $\theta$ fragmentos de madeira foram amostrados de sedimentos escavados para construção de canais de drenagem e datados por radiocarbono, tendo sido obtidas as seguintes idades:

$\begin{array}{lccc}\text { Número da amostra } & \begin{array}{c}\text { Idade radiocarbono } \\ \text { (anos A.P.) }\end{array} & \begin{array}{c}\text { Narureza da } \\ \text { amostra }\end{array} & \begin{array}{c}\text { Referência de } \\ \text { laboratório }\end{array} \\ \text { PS-06 } & 7.060 \pm 260 & \text { Concha } & \text { Bah-1120 } \\ \text { SD-10A } & 7.010 \pm 250 & \text { Concha } & \text { Bah-1005 } \\ \text { SD-03 } & 6.830 \pm 250 & \text { Concha } & \text { Bah-1007 } \\ \text { PS-07 } & 6.730 \pm 260 & \text { Concha } & \text { Bah-1121 } \\ \text { PS-26 } & 6.570 \pm 250 & \text { Madeira } & \text { Bah-1133 } \\ \text { PS-22 } & 6.570 \pm 260 & \text { Madeira } & \text { Bah-1135 } \\ \text { PS-09 } & 6.470 \pm 240 & \text { Concha } & \text { Bah-1123 } \\ \text { PS-08 } & 6.060 \pm 240 & \text { Concha } & \text { Bah-1122 } \\ \text { SD-10B } & 6.000 \pm 200 & \text { Madeira } & \text { Bah-1008 } \\ \text { PS-03 } & 5.560 \pm 230 & \text { Concha } & \text { Bah-1117 } \\ \text { PS-25 } & 5.460 \pm 230 & \text { Madeira } & \text { Bah-1132 } \\ \text { PS-19 } & 5.410 \pm 230 & \text { Concha } & \text { Bah-1109 } \\ \text { SD-04A } & 5.140 \pm 200 & \text { Concha } & \text { Bah-996 }\end{array}$


$\mathrm{Na}$ porção sul da planície costeira, separando o terraço pleistocênico do holocênico, existe uma zona baixa e estreita que foi ocupada por uma laguna em comunicação com a laguna central. Amostras de conchas de moluscos provenientes desses sedimentos lagunares foram datados por radiocarbono tendo sido obtidas as seguintes idades:

$\begin{array}{lcc}\text { Número da amostra } & \begin{array}{c}\text { Idade radiocarbono } \\ \text { (anos A.P.) }\end{array} & \text { Referência de laboratório } \\ \text { PS-14 } & 6.620 \pm 240 & \text { Bah-1107 } \\ \text { PS-12 } & 6.590 \pm 250 & \text { Bah-1105 } \\ \text { PS-14A } & 6.000 \pm 230 & \text { Bah-1108 } \\ \text { PS-13 } & 5.930 \pm 240 & \text { Bah-1106 }\end{array}$

A zona de cristas praiais holocênicas situada ao sul da foz do Rio Paraíba do Sul é dividida em dois por uma zona baixa paralela às cristas praiais e à praia atual. Conchas coletadas da extremidade sul desta zona foram datadas em $3.780 \pm 170$ anos A.P. (Bah-1280).

No meio das cristas praiais, na região do Cabo de São Tomé ocorrem quatro lagunas, a maioria já ressecada. Conchas de moluscos coletadas dos sedimentos superficiais indicaram as seguintes idades:

$\begin{array}{lcc}\text { Número da amostra } & \begin{array}{c}\text { Idade radlocarbono } \\ \text { (anos A.P.) }\end{array} & \text { Referência de laboratório } \\ \begin{array}{l}\text { Lagoa Salgada } \\ \text { PS-08 }\end{array} & 3.060 \pm 150 & \text { Bah-1102 } \\ \text { PS-16 } & 2.930 \pm 180 & \text { Bah-1114 } \\ \text { Lagoa das Ostras } & 2.920 \pm 150 & \text { Bah-999 } \\ \text { SD-05 } & 3.120 \pm 180 & \text { Bah-1111 } \\ \text { PS-15A } & 3.180 \pm 180 & \text { Bah-1112 } \\ \text { PS-15B } & & \text { Bah-1001 } \\ \text { Lagoa da Flecha } & & \text { Bah-1000 } \\ \text { SD-07 } & 3.000 \pm 150 & \\ \text { Lagoa Mololo } & 3.000 \pm 150 & \\ \text { SD-06 } & & \end{array}$


Amostras de conchas de moluscos coletadas de uma zona baixa paleolagunar, alongada e paralela às cristas praiais e à praia atual, dividindo em duas a planície costeira ao norte da foz do Rio Paraíba do Sul, forneceram as seguintes idades:

$\begin{array}{lcc}\text { Número da amostra } & \begin{array}{c}\text { Idade radiocarbono } \\ \text { (anos A.P.) }\end{array} & \text { Referência de laboratório } \\ \text { PS-31 } & 2.530 \pm 170 & \text { Bah-1098 } \\ \text { PS-89 } & 2.490 \pm 170 & \text { Bah-1261 } \\ \text { PS-30 } & 2.360 \pm 200 & \text { Bah-1097 }\end{array}$

d) Depósitos fluviais - Os sedimentos fluviais constituídos de argilas silticas amareladas, ocupam cerca de $1.280 \mathrm{~km}^{2}$ da planície costeira do Rio Paraíba do Sul, principalmente ao longo do eixo leste-oeste de Campos a São Tomé, onde são visíveis vários paleocanais sobre as fotografias aéreas. O padrão de distribuição dos sedimentos fluviais nesta planície indica que grande parte deles foi depositada na forma de um delta intralagunar, tendo os canais funcionado como distributários.

e) Depósitos paludiais - As turfas e os sedimentos areno-argilosos orgânicos compõem os depósitos paludiais típicos, que ocorrem nas margens da lagoa, nas calhas entre as cristas praiais e também em vales fluviais afogados sobre os sedimentos quaternários situados a oeste da planície costeira.

f) Depósitos de manguezais - Esses depósitos têm distribuição muito restrita, limitando-se a estreitas faixas próximas às desembocaduras dos rios Guaxindiba, Açu e Canal da Flecha. Talvez a área de maior desenvolvimento esteja situada ao norte da foz do Rio Parafba do Sul na região de Gargaú.

\subsubsection{Evolução paleogeográfica}

a) Trabalhos prévios

A planície costeira do Rio Paraíba do Sul foi estudada anteriormente por LAMEGO (1955), BACOCCOU (1971) (Fig. 57), ARAÚJO et al. (1975), DIAS \& GORINI (1979, 1980), DIAS (1981) e DIAS et al. (1984a, 1984b). Entretanto, nenhum desses autores considerou o papel desempenhado pelo abaixamento de nível relativo do mar, durante os últimos milhares de anos, na evolução paleogeográfica. 


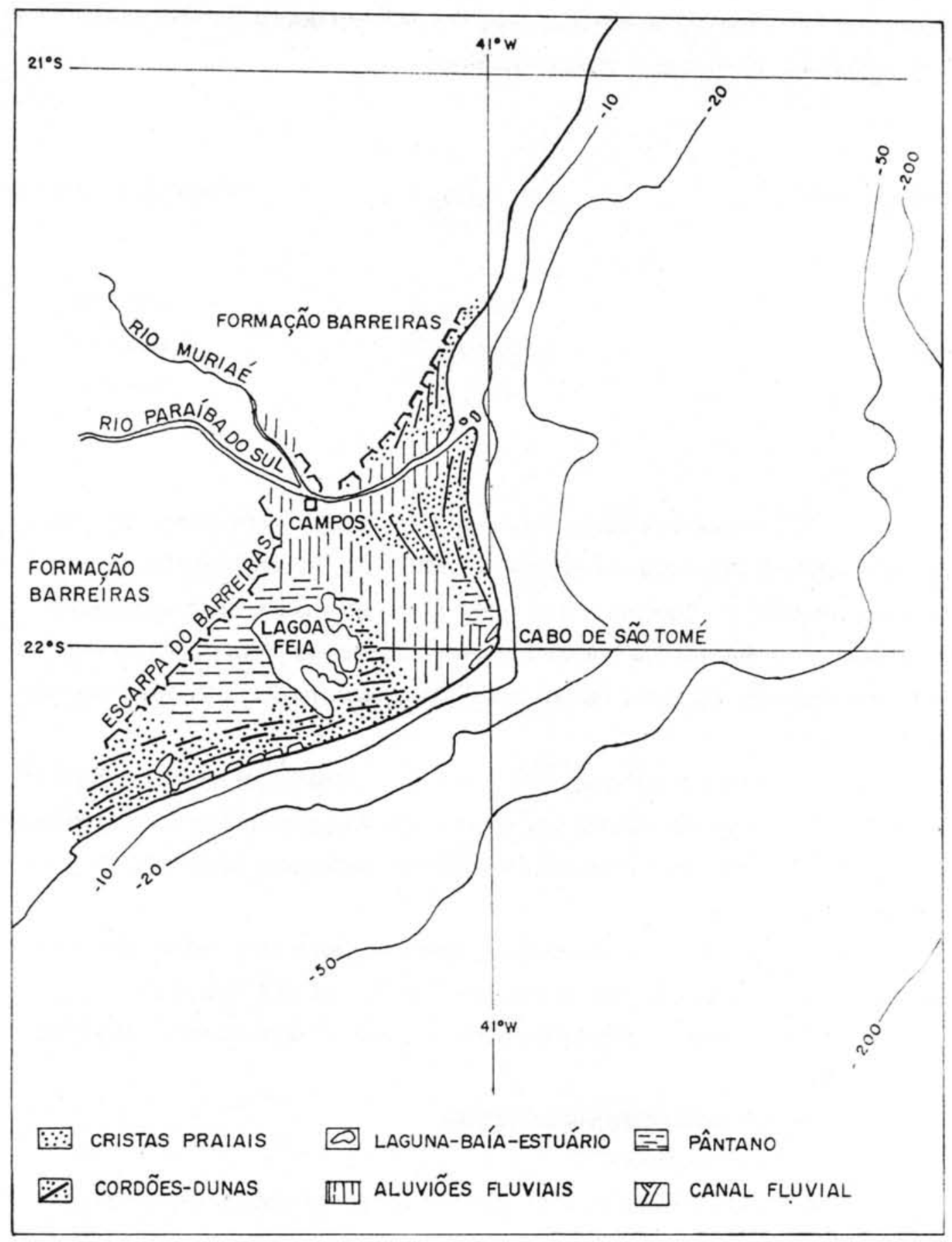

Figura 57 - Mapa geológico esquemático do "delta" do Rio Paraíba do Sul segundo BACOCCOLI (1971). 
Segundo ARAÚJO et al. (op.cit.) "a construção do complexo deltaico holocênico do Rio Paraíba do Sul iniciou-se depois que o mar atingiu seu nível mais elevado na transgressão Flandriana, desenvolvendo-se em duas fases distintas: uma abandonada e outra atuante". A reconstrução paleogeográfica desses autores foi baseada na idéia anterior de LAMEGO (op.cit.), que teria reconhecido várias fases de "deltação", passando pelas fases de delta do tipo Mississippi, do tipo Ródano, do tipo Paraíba do Sul e do tipo maré de Lagoa Feia. Não se pode negar a existência, no eixo Campos-São Tomé, de vestígios de um delta do tipo dominado por processos fluviais (tipo Mississippi). Entretanto, um delta deste tipo não poderia ser construído mar adentro em litoral de alta energia como foi proposto por LAMEGO (op.cit.) e ratificado por ARAÚJO et al. (op.cit.) (Fig. 58). Então é necessário admitir que os sedimentos transportados pelo Rio Paraíba do Sul depositaram-se em zona de energia fraca, isto é, durante uma parte de sua história o rio desembocava dentro de uma paleolaguna, onde construiu então um delta intralagunar, fato demonstrado pela existência na frente dos sedimentos fluviais de depósitos lagunares ricos em conchas de moluscos típicos de águas salobras. O modelo de ARAÚJO et al. (op.cit.) foi estabelecido com base em esquemas desenvolvidos em outras regiões do mundo, onde as condições de energia do meio receptor (oceano) são completamente diferentes da região da foz do Rio Paraíba do Sul.

b) Modelo proposto neste trabalho

Seguindo a sistemática anteriormente adotada para a planície costeira do Rio Doce, foi possível reconhecer na foz do Rio Paraíba do Sul os seguintes estádios evolutivos:

- $1^{2}$ estádio - Corresponde à fase de sedimentação continental terciária da Formação Barreiras, quando o clima era semi-árido e o nível marinho provavelmente bem abaixo do atual.

- $2^{\circ}$ e $3^{\circ}$ estádios - Essas fases correspondem, respectivamente, à Transgressão Antiga e à deposição de leques aluviais coalescentes pós-Barreiras, mas não foram até o momento reconhecidos na planície costeira aqui descrita.

- 4 estádio - Máximo da Penúltima Transgressão, ocorrida há 123.000 anos A.P. Nesta época o mar se situava $8 \pm 2 \mathrm{~m}$ acima do atual. Os sedimentos da Formação Barreiras foram erodidos e formou-se uma falésia. O curso inferior do Rio Paraíba do Sul formava um estuário e a porção inferior de outros vales da região também foi afogada.

$5^{2}$ estádio - Formação dos terraços pleistocênicos - Encostadas nas falésias esculpidas nos sedimentos da Formação Barreiras, na fase anterior, foram depositadas cristas praiais ao mesmo tempo em que as desembocaduras de muitos vales eram fechadas por barras arenosas formando-se lagunas. A configuração das cristas praiais da região de Quiçamã sugere que elas tenham sido construldas em diversas fases ligadas a mudanças do nivel marinho, como as que 


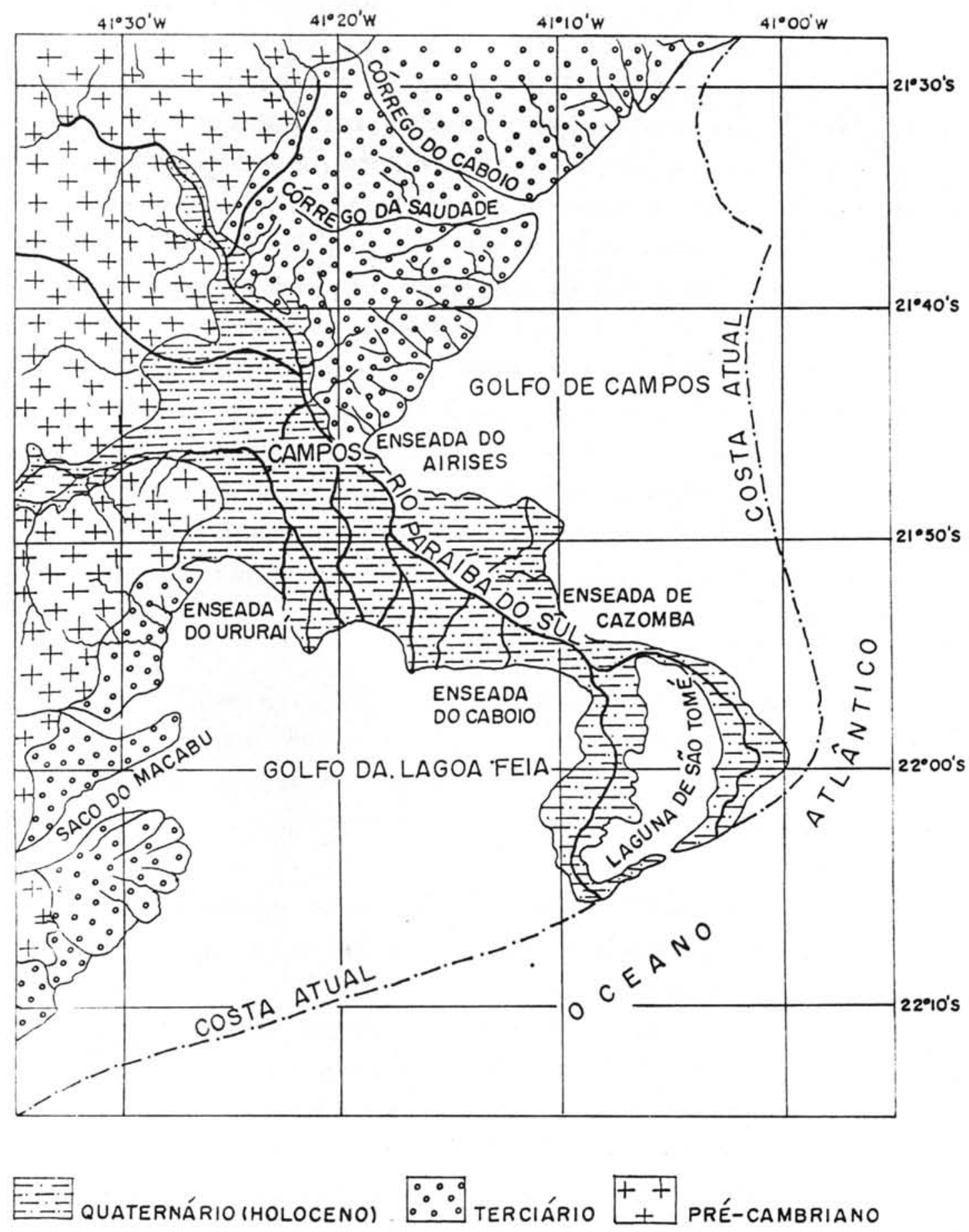

Figura 58 - Primeira etapa de evolução "delta holocênico" do Rio Paraíba do Sul segundo LAMEGO (1955) e ARAÚJO et al. (1975). 
ocorreram nos últimos 5.000 anos. Uma rede hidrográfica, no prolongamento dos vales entalhados nos sedimentos da Formação Barreiras ou orientada pelas cristas praiais, instalou-se sobre os terraços pleistocênicos.

A partir do estádio 6, que no modelo geral de evolução da porção central do litoral brasileiro corresponde à parte final da última transgressão, a evolução da planície costeira do Rio Paraíba do Sul pôde ser estabelecida, como no caso do Rio Doce, com grande detalhe. Reconstruções paleogeográficas pormenorizadas nos permitiram evidenciar a existência de um antigo sistema de ilhas-barreiras/laguna e de um paleodelta intralagunar. Além disso, examinando-se o mapa geológico de formações quaternárias da planície costeira do Rio Parafba do Sul (Fig. 56) constata-se que a sedimentação arenosa holocênica é caracterizada por uma extensa área de deposição ao norte do Cabo de São Tomé e por uma zona de não-deposição e de transição para o sul. Em termos médios pode-se dizer que a progradação de depósitos arenosos holocênicos ocorreu sob condições hidrodinâmicas de ondas eficazes provenientes do setor sul. Entretanto, grandes discordâncias nos alinhamentos das antigas cristas praiais (Fig. 59) evidenciam a existência de fases de construção interrompidas por épocas de erosão, indicando modificações nas condições hidrodinâmicas em conexão, seja com variações de nível relativo do mar, seja com mudanças no sentido de atuação das ondas dominantes.

A evolução da porção holocênica da planície costeira do Rio Parafba do Sul pode ser reconstituida da seguinte maneira:

- Estádio A: Antes de 5.100 anos A.P. (Fig. 60) - Corresponde à época de formação de um sistema de ilhas-barreiras/laguna. As datações por radiocarbono mostram que este sistema existia já antes de cerca de 7.000 A.P. A posição das ilhas-barreiras há cerca de 5.100 anos A.P. é mostrada na Figura 60, onde se pode verificar que a zona situada ao norte do Cabo de São Tomé formava uma armadilha para os sedimentos sob condições hidrodinâmicas geradas pelas ondas eficazes do setor sul. Contrariamente, a área ao sul do Cabo de São Tomé constituía uma zona principalmente de trânsito. É interessante verificar que neste setor as ilhas-barreiras não se situavam, ao redor de 5.100 anos A.P., nas suas posições mais internas. De fato, é impossivel relacionar os testemunhos mais internos, situados ao norte do Cabo de São Tomé, com os situados ao sul. Para que a configuração do Cabo de São Tomé seja compatível com as condições hidrodinâmicas, somos obrigados a deslocar as posições das ilhas-barreiras para o sul, conforme se vê na Figura 60.

Como no caso do Rio Doce, a partir do momento de aparecimento da paleolaguna, o Rio Paraíba do Sul também passou a construir um delta intralagunar no seu interior. Nós temos pouco controle para acompanhar o desenvolvimento do delta intralagunar mas, há cerca de 5.100 anos A.P., sabe-se que nenhum braço do Rio Paraíba do Sul atingia diretamente o oceano. De fato, as 


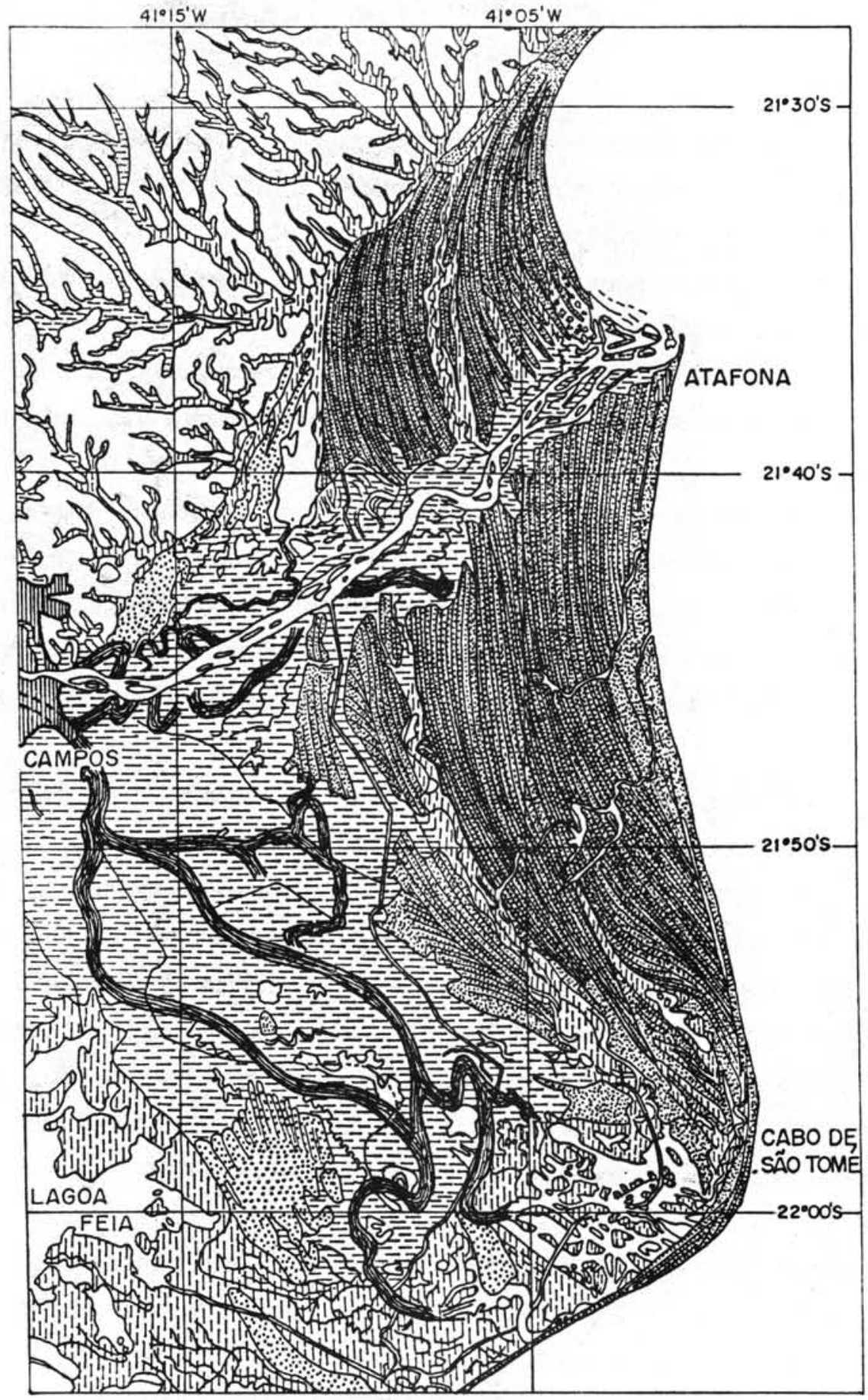

Figura 59 - Detalhes geométricos dos alinhamentos das cristas praiais holocênicas da planície costeira do Rio Paraiba do Sul. Para compreensão das legendas veja Figura 56. 


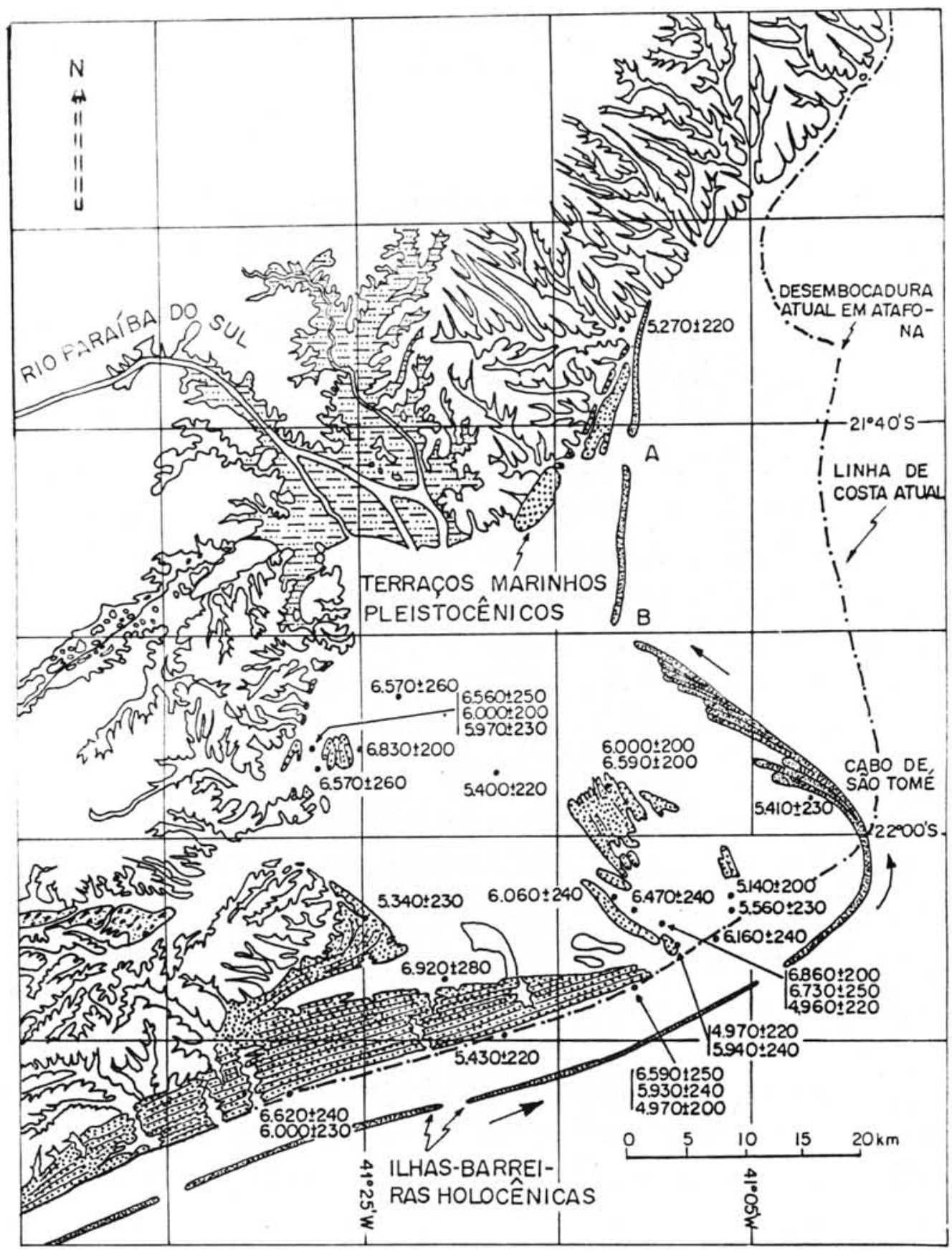

Figura 60 - Estádio A: Fase anterior a 5.100 anos A.P. - Situação do sistema de ilhas-barreiras/laguna ao redor de 5.100 anos A.P., correspondente ao nível máximo holocênico. Podem ser vistos testemunhos de terraços marinhos pleistocênicos, situação da linha de costa atual e a posição da foz do Rio Paraíba do Sul hoje em dia. 
desembocaduras A e B (Fig. 60) possuem esporões em gancho recurvados para o interior da laguna, indicando que a energia da laguna era sobrepujada pela do oceano. Por outro lado, a saída direta para o oceano de um dos braços do delta intralagunar é, em geral, indicada por modificações na geometria das cristas praiais.

Estádio B: Entre 5.100 e 3.900 anos A.P. - No momento do máximo nfvel marinho de 5.100 anos A.P., a configuração do sistema de ilhas-barreiras/laguna era tal que existia, ao norte, uma grande concavidade que podia funcionar como uma armadilha para as areias supridas pelo abaixamento de nivel relativo do mar e transportadas para o norte por deriva litorânea.

Subestádio B-1: Primeira fase de construção - A primeira zona de acumulação deve ter funcionado entre o Cabo de São Tomé e a desembocadura A. Muito rapidamente a desembocadura B foi deslocada para o norte fundindo-se com a desembocadura A (Fig. 61). Um segundo esporão arenoso desenvolveu-se a partir do Cabo de São Tomé rumo ao norte, paralelamente à primeira zona de acumulação, mas sem ultrapassar a desembocadura A (Fig. 62). Ela delimitou uma laguna alongada cujos vestígios são ainda hoje bem visiveis (Fig. 59).

Subestádio B-2: Saída de um braço do delta intralagunar pelo local da desembocadura A (Fig. 63) - Diferentemente do que ocorreu no Rio Doce, um braço do delta intralagunar do Rio Paraíba do Sul deve ter saído diretamente ao oceano antes do abaixamento "brusco" do nível relativo do mar que ocorreu entre 4.200 e 3.900 anos A.P. Esta saída aconteceu pelo mesmo sítio da desembocadura lagunar pré-existente. A largura do paleocanal deste braço do Rio Paraíba do Sul que saiu diretamente ao oceano é claramente inferior a do canal atual (Fig. 59), o que leva a pensar que os outros braços do delta intralagunar tenham continuado em atividade e que este continuou a se desenvolver para o sul.

Subestádio B-3: Fase de construção (Fig. 64) - A partir da saída direta de um braço do delta intralagunar, os aportes arenosos do Rio Paraíba do Sul passaram a contribuir na construção dos terraços arenosos holocênicos. O estudo dos graus de arredondamento de grãos de quartzo mostrou que as areias transportadas pelo curso fluvial depositavam-se ao norte da desembocadura (areias mais angulosas), enquanto que as areias depositadas entre o Cabo de São Tomé e a desembocadura são formadas por grãos mais arredondados de origem predominantemente marinha (MARTIN et al., 1985b). Durante todo este período, as condições hidrodinâmicas devem ter sido geradas pelas ondas eficazes do setor sul.

Subestádio B-4: Primeira fase de erosão (Fig. 65) - Discordâncias acentuadas nos alinhamentos das cristas praiais em torno da desembocadura e ao norte do Cabo de São Tomé indicam periódicas mudanças das condições hidrodinâmicas. Conchas de moluscos coletadas nas cristas praiais depositadas no decorrer da fase de construção seguinte indicaram idades de $4.390 \pm 200$ 


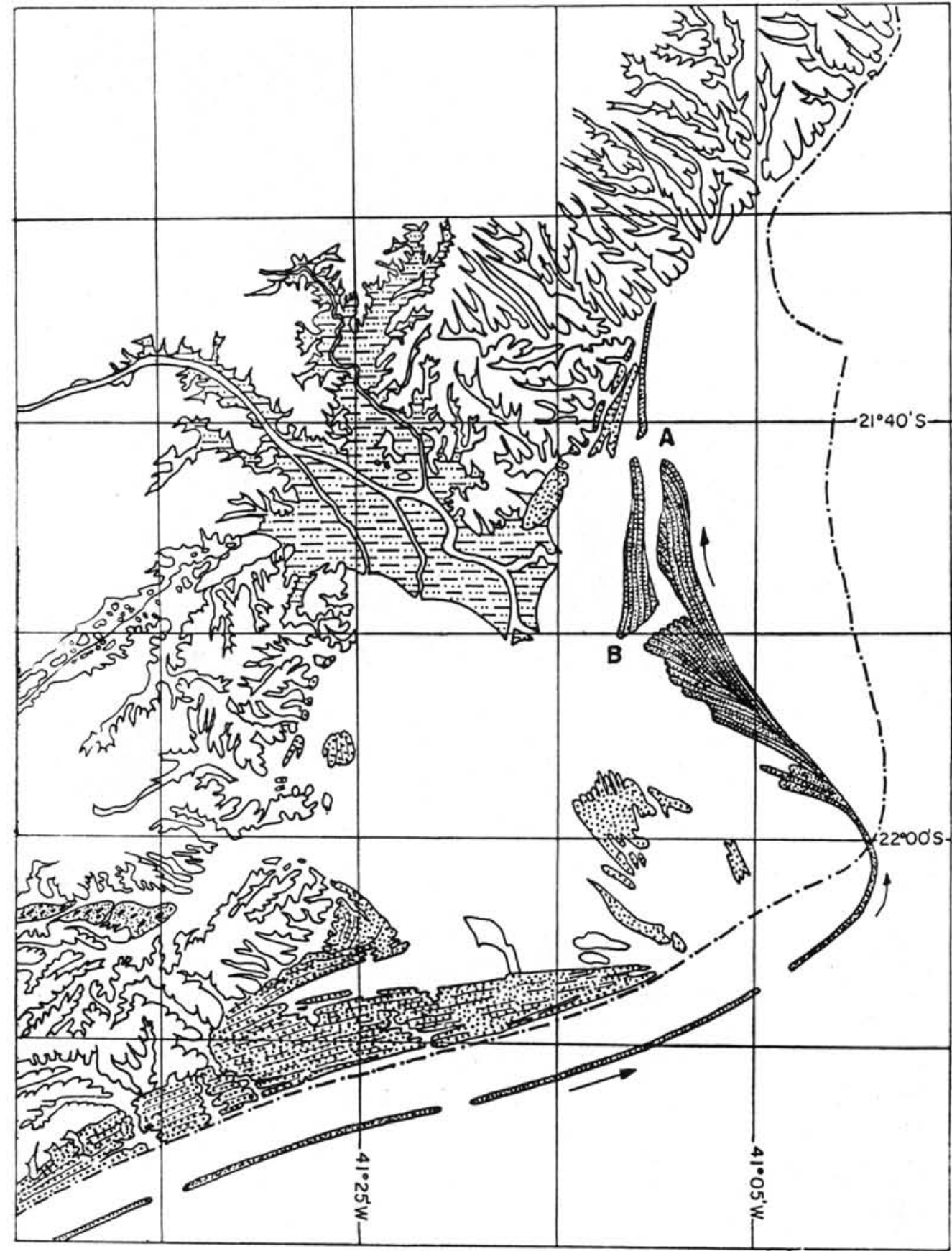

Figura 61 - Subestádio B-1a: Primeira fase de construção do intervalo de tempo correspondente a 5.100 - 3.900 anos A.P. 


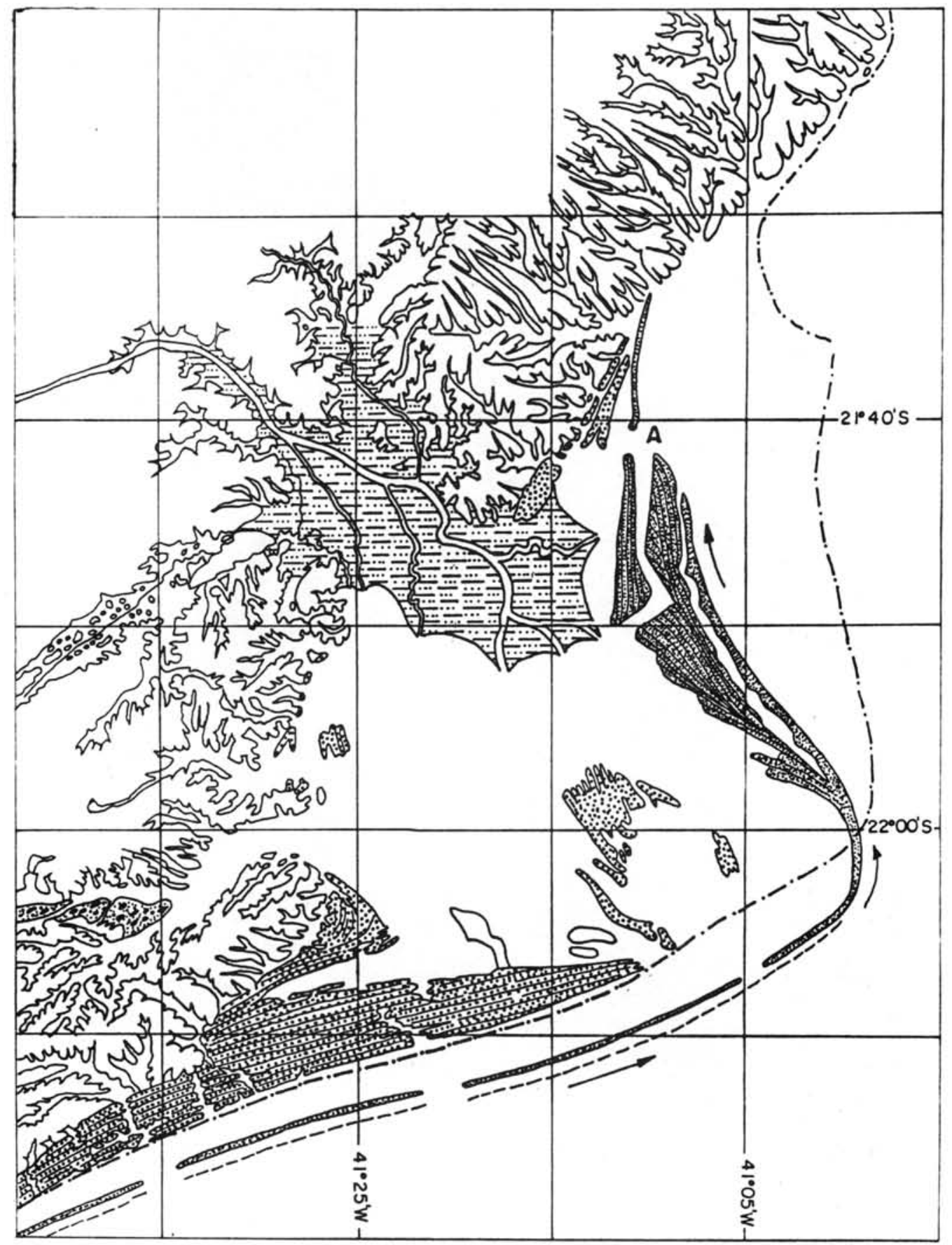

Figura 62 - Subestádio B-1b: Segunda fase de construção do intervalo de tempo correspondente a 5.100 - 3.900 anos A.P. 


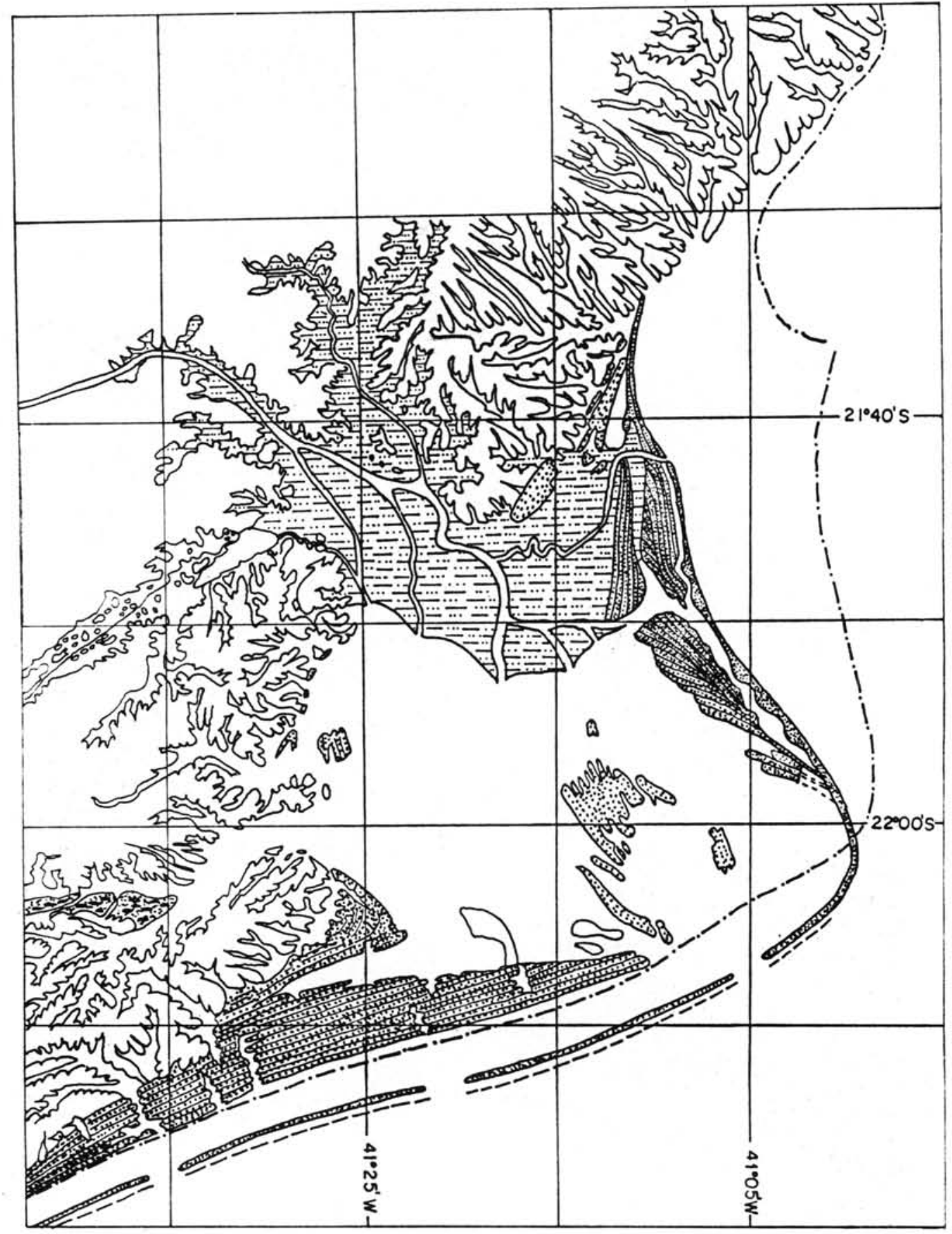

Figura 63 - Subestádio B-2: Saída direta para o mar de um distributário do delta intralagunar no intervalo de tempo correspondente a $5.100-3.900$ anos A.P. 


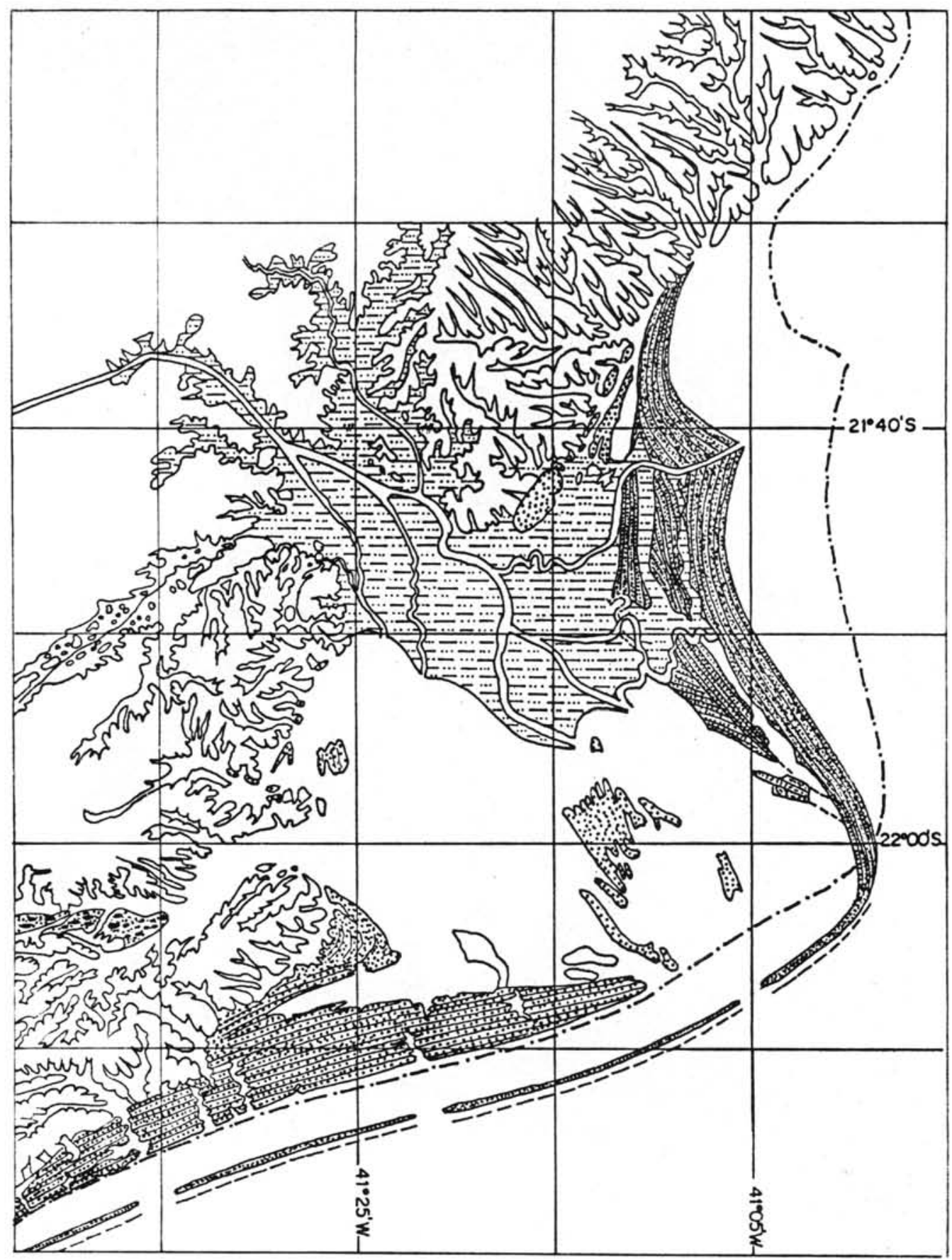

Figura 64 - Subestádio B-3: Progradação a partir da desembocadura A no intervalo de tempo correspondente a $5.100-3.900$ anos A.P. 


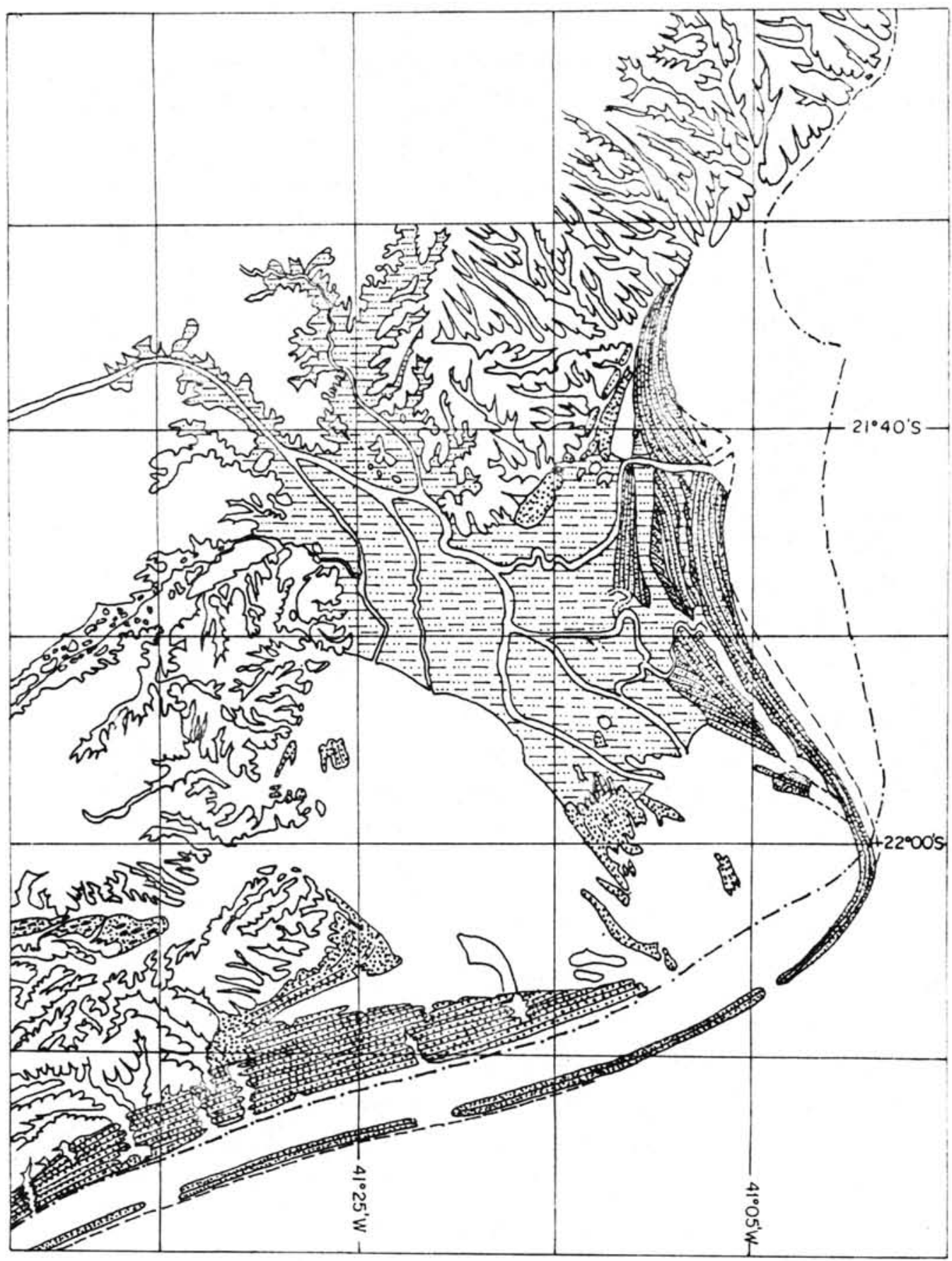

Figura 65 - Subestádio B-4: Primeira fase de erosão a partir da desembocadura A no intervalo de tempo correspondente a $5.100-3.900$ anos A.P. 
anos A.P. (Bah-1094) e 4.380 200 anos A.P. (Bah-1093). Então, é evidente que esta fase de erosão é anterior a 4.400 anos A.P. e não poderia estar ligada à subida do nível marinho entre 3.900 e 3.600 anos A.P. Pelo contrário, a inflexão da desembocadura para o sul favorece a idéia de modificação na direção das ondas eficazes que então provinham do setor norte. Nessas novas condições, a configuração da linha de costa ficou em desequilíbrio. Parece que esta erosão fol acompanhada de deposição ao sul do Cabo de São Tomé, mas não restou nenhum testemunho, sabendo-se apenas que esta eventual zona de deposição deveria situar-se ao largo da linha de costa atual.

Subestádio B-5: Segunda fase de construção (Fig. 66) - Retomada da progradação nas condições hidrodinâmicas geradas pelas ondas eficazes provenientes do setor sul. No decorrer desta fase a desembocadura foi deslocada ligeiramente para o norte de maneira não contínua. Os escalonamentos na acreção lateral das cristas praiais traduzem períodos de variação de energia do Rio Paraíba do Sul, que serão estudados mais adiante.

Subestádio B-6: Segunda fase de erosão (Fig. 67) - Discordâncias muito conspícuas nos alinhamentos das cristas praiais em ambas as margens da desembocadura ao norte do Cabo de São Tomé indicam períodos de erosão bastante semelhantes a aqueles produzidos no subestádio B-4 (Fig. 65). É claro que deve resultar de modificações nas condições hidrodinâmicas. Nós veremos mais adiante que as lagunas (Salgada, das Ostras, etc.) situadas ao norte do Cabo de São Tomé, cuja origem está ligada à subida de nível relativo do mar, foram formadas após esta fase de erosão. Nós podemos então pensar que a mudança das condições hidrodinâmicas tenham resultado de inversão no sentido das ondas eficazes, que então eram provenientes do setor norte. Pode-se imaginar que esta inversão tenha ocorrido ao redor de 3.900 anos A.P.

Nesta época, o delta intralagunar não havia preenchido totalmente a laguna, principalmente na região do Farol de São Tomé. Sobre as fotografias aéreas pode-se ver claramente um paleocanal não margeado por sedimentos fluviais, que foi recoberto pela barreira atual. Parece que ele saiu ao mar na época do abaixamento "brusco" de nivel relativo do mar antes de 3.900 anos A.P., em uma etapa quando a barreira arenosa situava-se em posição mais externa do que atualmente. Mas os eventuais testemunhos desta saída devem ter desaparecido.

Estádio C: 3.900-3.600 anos A.P. - Uma série de reconstruções paleogeográficas (Fig. 68) mostrou que as lagunas (Salgada, das Ostras, etc.) situadas na região de Cabo de São Tomé foram formadas após os deslocamentos da barreira arenosa rumo ao continente, nas condições hidrodinâmicas geradas pelas ondas eficazes do setor sul. Esses deslocamentos da barreira arenosa propiciaram a formação dos esporões que se afastam da costa na altura do Cabo de São Tomé, isolando lagunas alongadas. Deslocamento tão importante da barreira arenosa rumo ao continente só poderia resultar da elevação de nível relativo do mar. Na mesma época, na porção norte da planície, 


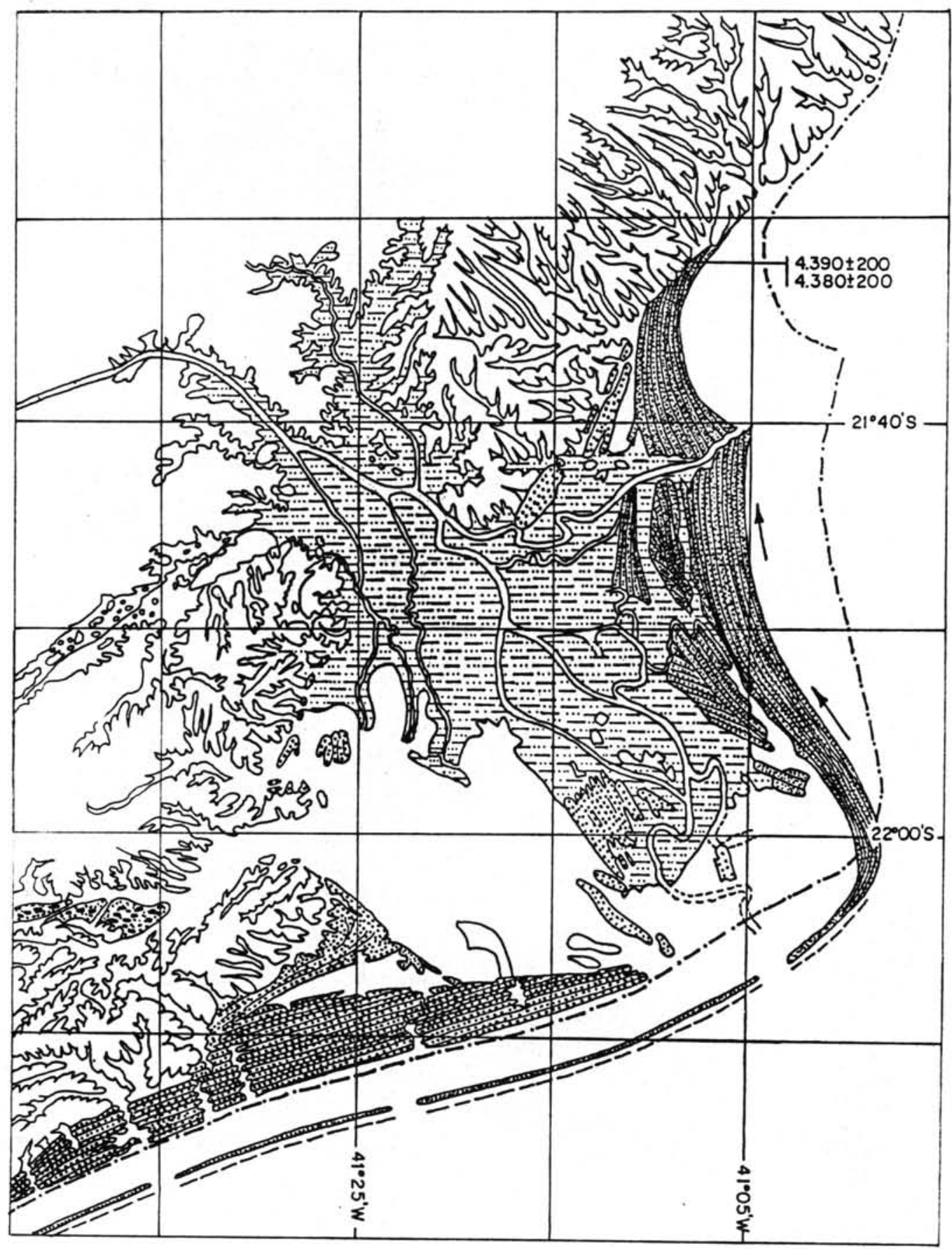

Figura 66 - Subestádio B-5: Segunda fase de construção a partir da desembocadura A no intervalo de tempo correspondente a 5.100 - 3.900 anos A.P. 


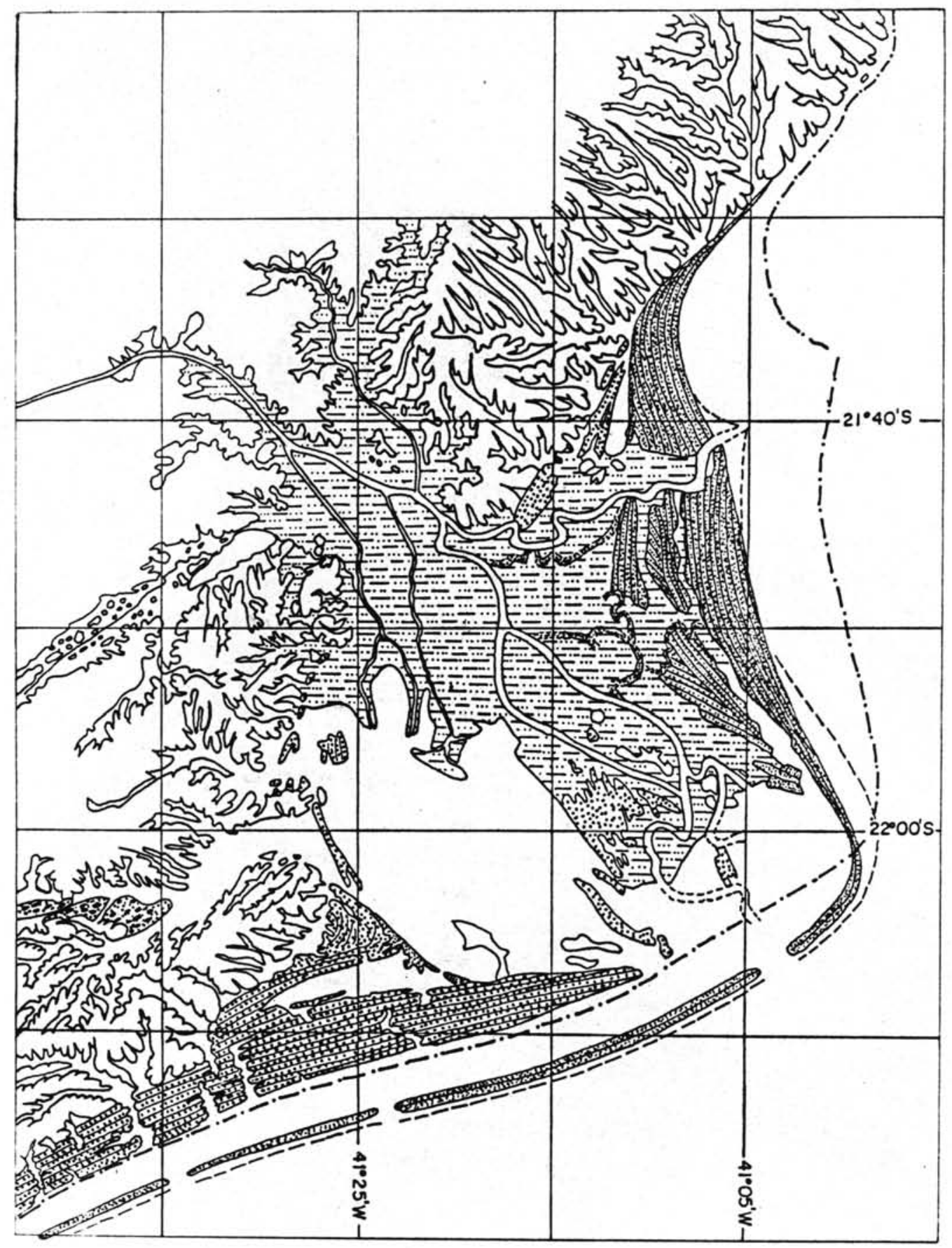

Figura 67 - Subestádio B-6: Segunda fase de erosão a partir da desembocadura A no intervalo de tempo correspondente a $5.100-3.900$ anos A.P. 


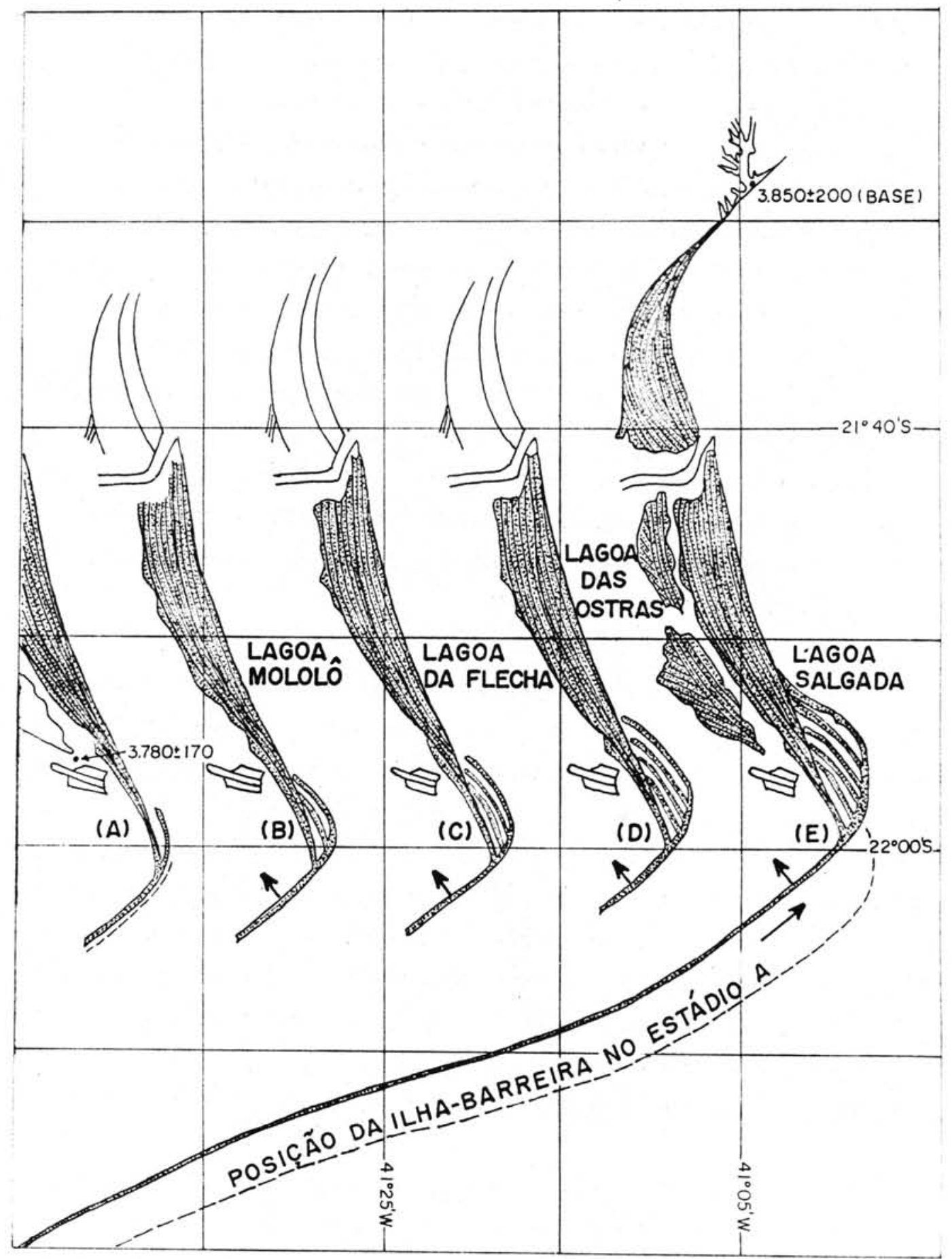

Figura 68 - Estádio C: Seqüência de formação das lagunas costeiras Mololô, da Flecha, das Ostras e Salgada, ao norte do Cabo de São Tomé, entre 3.900 e 3.600 anos A.P. 
uma pequena barreira arenosa fechou um vale entalhado nos sedimentos da Formação Barreiras. Conchas coletadas na base desta barreira forneceu uma idade de $3.850 \pm 200$ anos A.P. (Bah-1102) em concordância com a subida de nível relativo do mar que ocorreu entre 3.900 e 3.600 anos A.P.

Estádio D: $3.600-2.800$ anos A.P. - Após a formação da última laguna (Salgada), verificou-se uma repetição da construção sempre sob condições hidrodinâmicas geradas por ondas eficazes do setor sul. A acumulação ocorreu inicialmente na armadilha sedimentar que existia na extremidade do esporão arenoso que havia isolado a Laguna Salgada. Então, esta laguna perdeu a comunicação com o oceano (Fig. 69), entretanto, nesta mesma época as diversas lagunas menores deveriam estar ainda em comunicação com a laguna maior que existia na região do Farol de São Tomé, como mostram as datações de conchas que indicaram idades de $3.800 \pm 140$ anos A.P. (Bah998) e $3.000 \pm 170$ anos A.P. (Bah-1124). Por outro lado, sete amostras de conchas coletadas em superfície de diversas lagunas do Cabo de São Tomé indicaram idades em torno de 3.000 anos A.P. Como as conchas datadas foram coletadas em superfície, pode-se supor que essas lagunas tenham sofrido ressecação nesta época, que corresponde ao início de um abaixamento "mais rápido" de nível relativo do mar. Durante este período, a construção prosseguiu sob condições hidrodinâmicas geradas pelas ondas eficazes do setor sul (Fig. 70).

Estádio E: $2.700-2.500$ anos A.P.

Subestádio E-1: A reconstrução paleogeográfica também mostrou uma fase de erosão generalizada entre o Cabo de Tomé e o norte da planície costeira (Fig. 71). Ao norte da desembocadura, esta erosão se processou obliquamente aos alinhamentos das antigas cristas praiais, fato que facilita o seu reconhecimento. Por outro lado, ao sul da desembocadura, a erosão ocorreu paralelamente aos alinhamentos das antigas cristas praiais, fato que dificulta a sua identificação. Esta erosão generalizada não poderia ter resultado de modificação no sentido de atuação das ondas eficazes. De fato, ondas eficazes de NE teriam propiciado uma erosão oblíqua aos alinhamentos das antigas cristas praiais, ligeiramente ao norte do Cabo de São Tomé, como nos subestádios B-4 e B-6. Então, é mais lógico relacionar à rápida elevação de nível do mar, que se produziu entre 2.700 e 2.500 anos A.P. Isto parece ainda mais verdadeiro quando se sabe que as conchas provenientes de uma paleolaguna formada no decorrer do estádio subseqüente indicaram idades entre 2.500 e 2.400 anos A.P.

Subestádio E-2: Retomada da progradação sob condições hidrodinâmicas geradas por ondas eficazes do setor sul. Ao norte da desembocadura a retomada da progradação não se processou em contato com os depósitos anteriores, mas um pouco em frente a eles, formandose uma laguna alongada estendendo-se da desembocadura à extremidade da planície (Fig. 72). Três amostras de conchas coletadas nos sedimentos desta paleolaguna indicaram idades seguintes: 


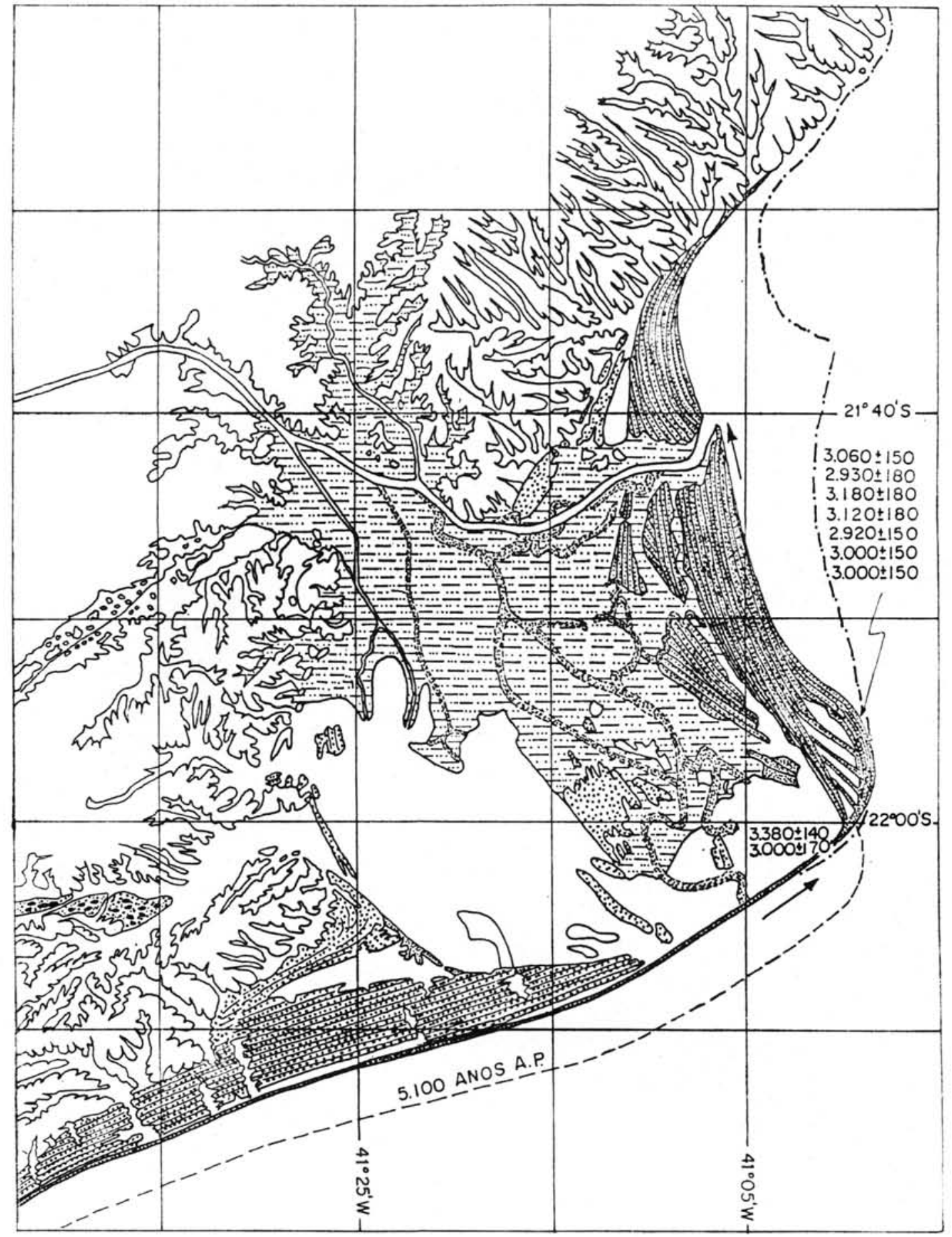

Figura 69 - Subestádio D-1: Fechamento das lagunas ao norte do Cabo de São Tomé no intervalo de tempo correspondente a $3.600-2.800$ anos A.P. 


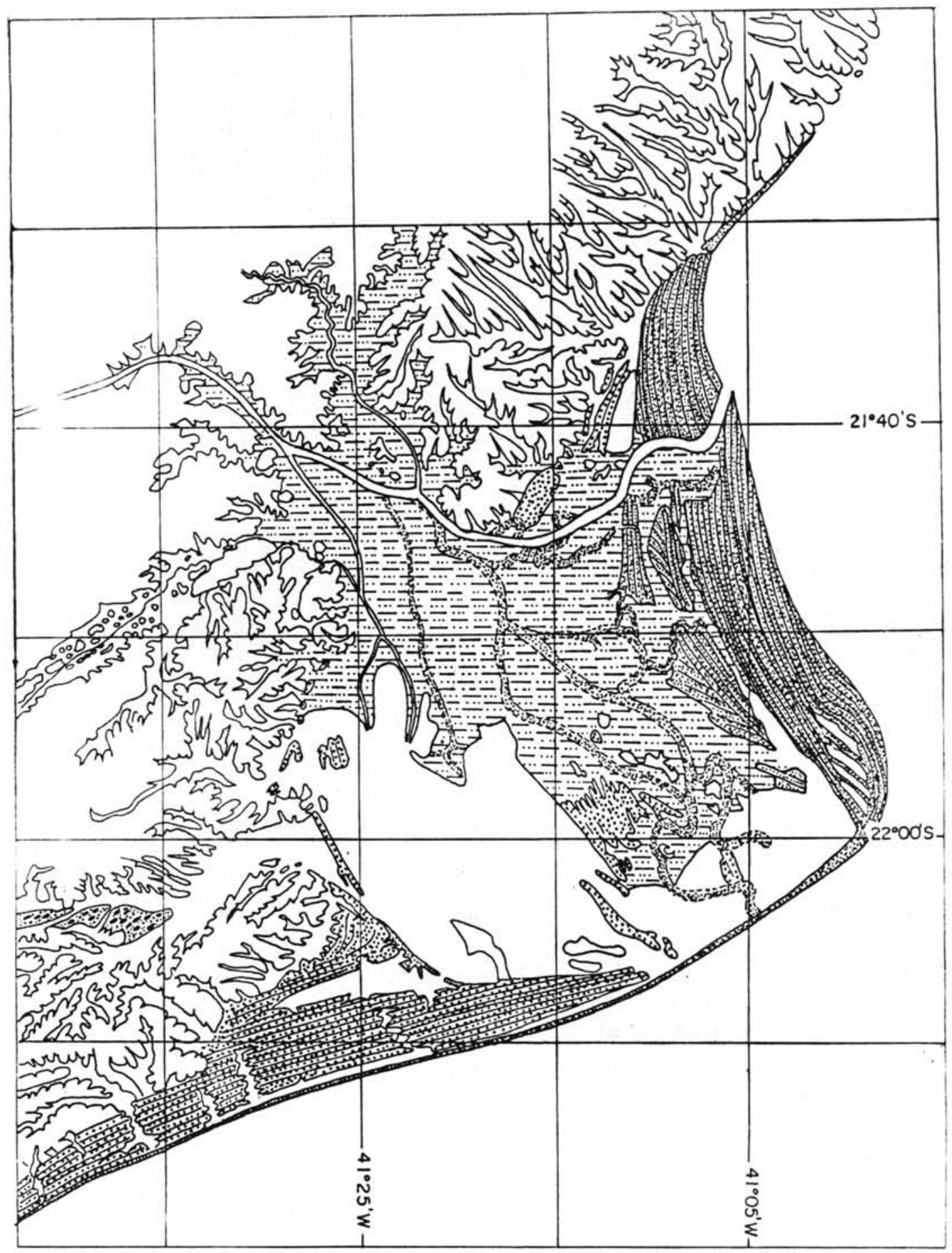

Figura 70 - Subestádio D-2: Construção de cristas praiais sob condiçōes hidrodinâmicas geradas por ondas do setor sul no intervalo de tempo correspondente a 3.600 - 2.800 anos A.P. 


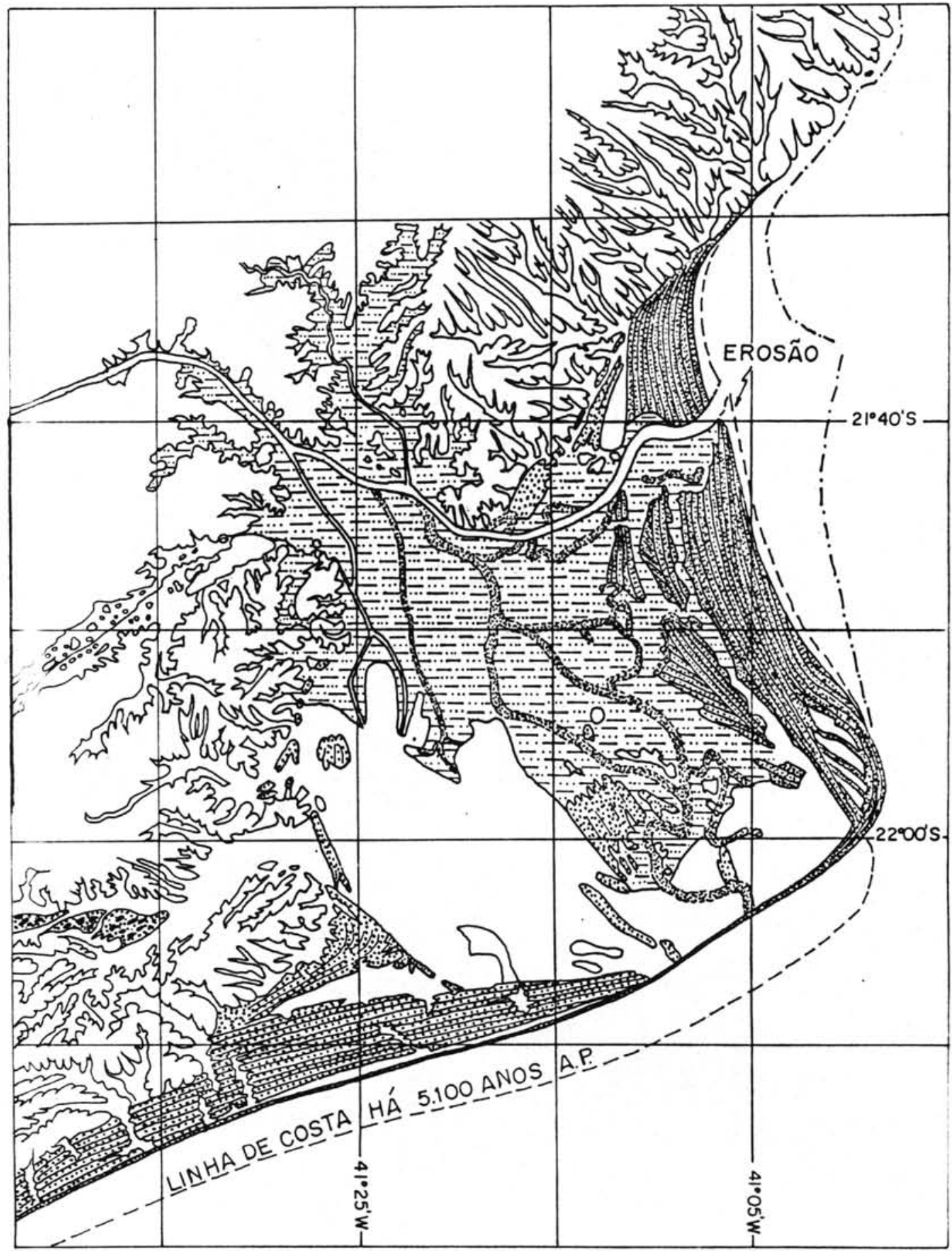

Figura 71 - Subestádio E-1: Erosão generalizada no intervalo de tempo correspondente a 2.700 - 2.500 anos A.P 


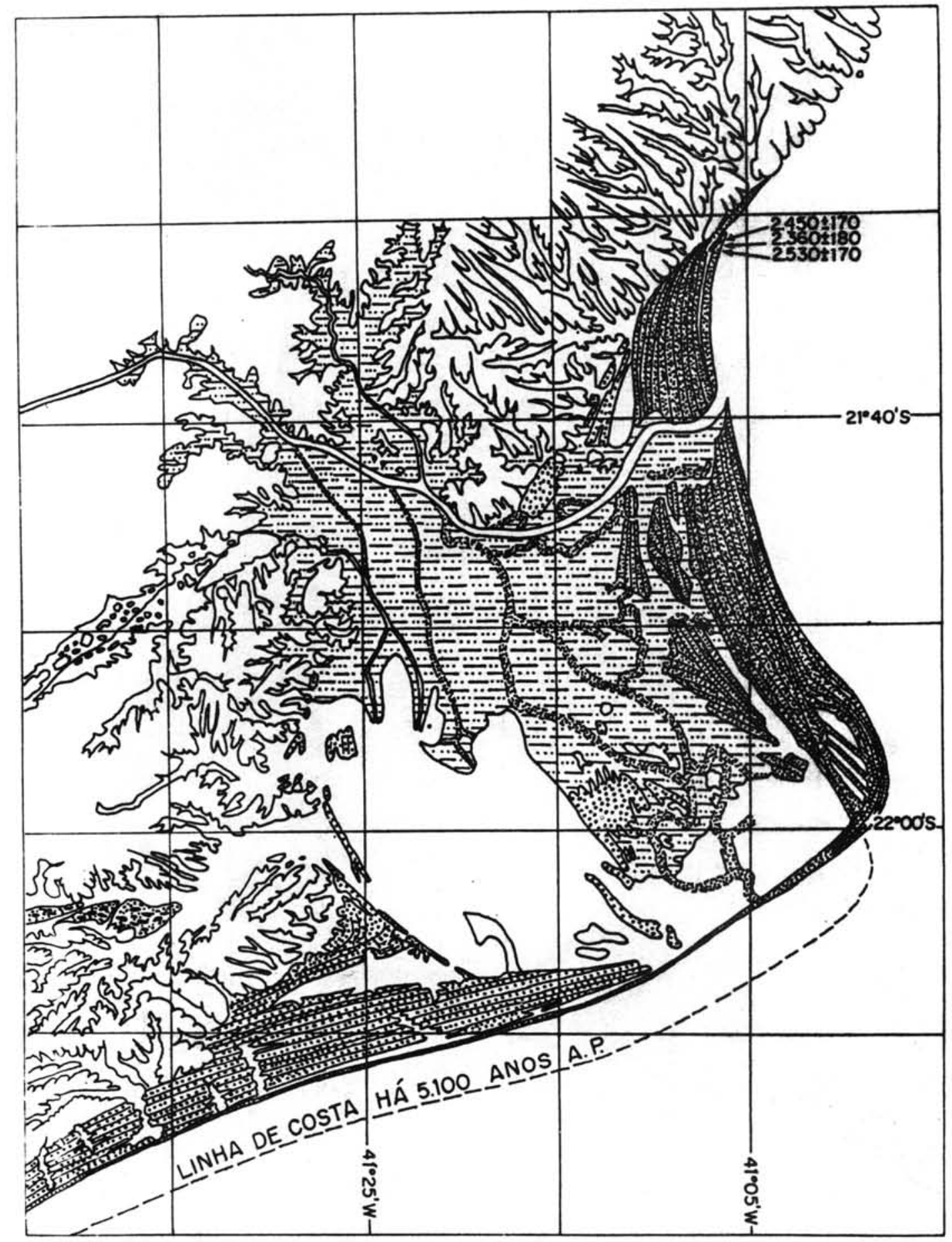

Figura 72 - Subestádio E-2: Fase de construçăo no intervalo de tempo correspondente a 2.700 - 2.500 anos A.P. 
$2.530 \pm 170$ anos A.P. (Bah-1098), $2.490 \pm 170$ anos A.P. (Bah-1261) e 2.360 \pm 180 anos A.P. (Bah-1097). É interessante notar que não se formou um depósito saliente em torno da desembocadura, como foi o caso dos subestádios B-2 (Fig. 63) e B-5 (Fig. 66).

Subestádio E-3: A reconstrução paleogeográfica da Figura 73 mostra uma inflexão da desembocadura para o sul. Além disso, um estudo dos graus de arredondamento de grãos de quartzo indicou que as areias transportadas pelo Rio Parafba do Sul (grãos angulosos) não são depositadas ao norte da desembocadura, como seria o caso sob condições hidrodinâmicas geradas por ondas eficazes do setor sul. Então, deve-se pensar que durante este período, as condições hidrodinâmicas eram geradas por ondas eficazes do setor norte.

Por outro lado, parece bizarro que esta inversão das ondas eficazes não seja traduzida por erosão localizada na zona da desembocadura e ao norte do Cabo de São Tomé, como foram os casos dos subestádios B-4 e B-6. Porém, nós vimos que no estádio anterior os depósitos em torno da desembocadura não apresentavam uma forma saliente. Além disso, na região do Cabo de São Tomé, a linha de costa no estádio anterior se situava defronte da costa atual, de modo que eventuais discordâncias nos alinhamentos das antigas cristas praiais não teriam sido conservadas.

Subestádio E-4: Retomada da progradação com o abandono da antiga desembocadura e formação de uma nova foz desviada para o norte (Fig. 74). As areias angulosas transportadas pelo Rio Parafba do Sul depositaram-se novamente ao norte da desembocadura, traduzindo um retorno às condições hidrodinâmicas geradas por ondas do setor sul. Essas condições se mantiveram durante um período bastante longo. Ao fim disto, a linha de costa, na zona do Cabo de São Tomé, situava-se claramente mais costa afora do que a atual (Fig. 75); então, ela ficou em grande desequilíbrio em relação às condições hidrodinâmicas geradas pelas ondas eficazes provenientes do setor norte. A sedimentação ao redor da desembocadura foi caracterizada por acentuada assimetria $e$ por uma acumulação escalonada ao sul. Esses escalonamentos realçados pelas discordâncias nos alinhamentos das cristas praiais testemunhariam variações de energia do Rio Paraíba do Sul, como será visto mais adiante.

Subestádio E-5: A reconstrução paleogeográfica que aparece na Figura 76 mostra a existência de uma zona de acentuada erosão na região do Cabo de São Tomé. Esta erosão deve ter sido acompanhada de acumulação equivalente na região do Farol de São Tomé. Outra zona de erosão foi também produzida ao sul da desembocadura. Esta modificação nas condições hidrodinâmicas não poderia ser senão o resultado de uma inversão no sentido das ondas eficazes, que provinham agora do setor norte. Em função das datações de conchas provenientes de cristas praiais da porção norte da planície pode-se imaginar que este período de erosão tenha ocorrido ao redor de $1.300 \pm 200$ anos A.P. 


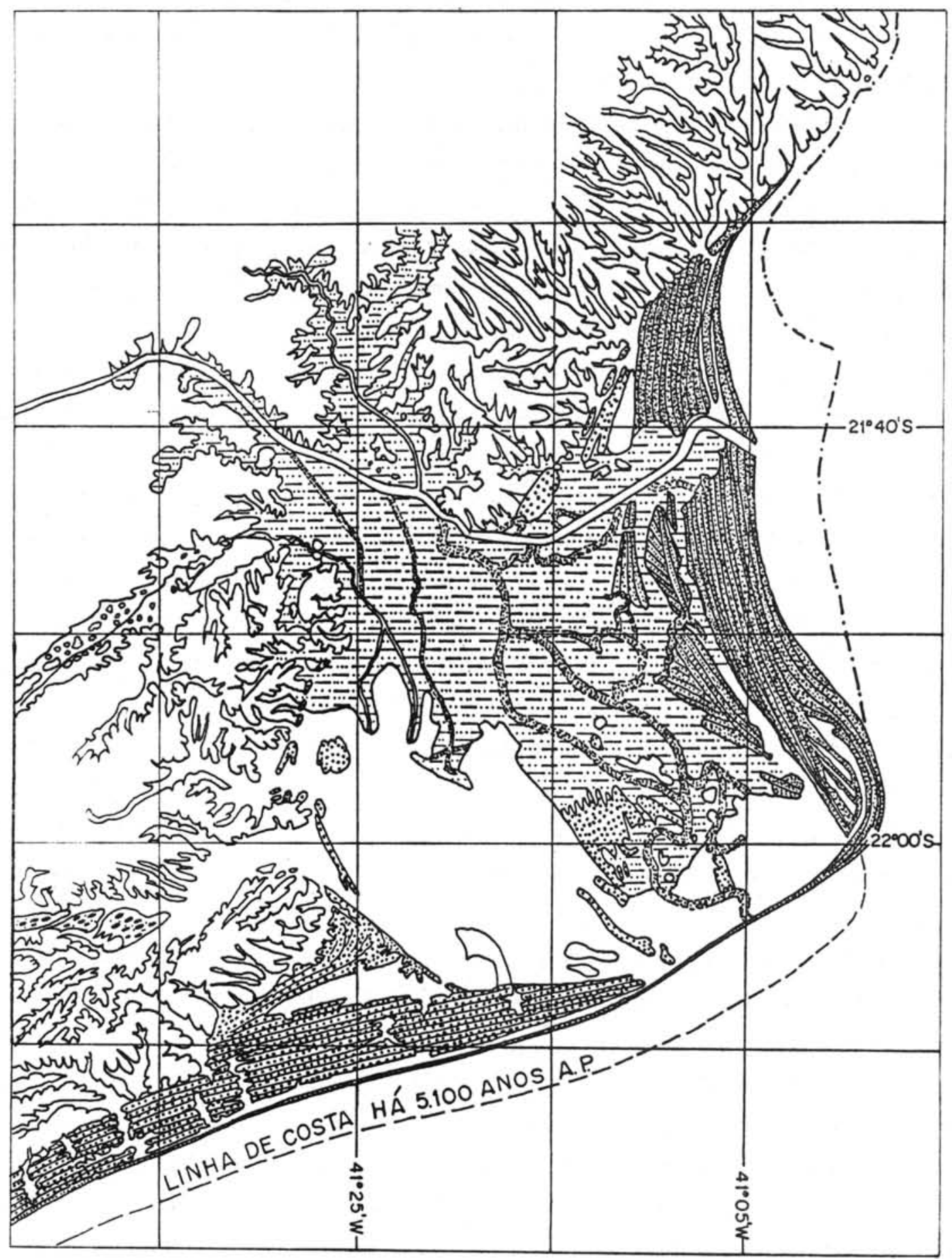

Figura 73 - Subestádio E-3: Progradação sob condiçōes hidrodinâmicas geradas por ondas do setor norte no intervalo de tempo correspondente a $2.500-0$ anos A.P. 


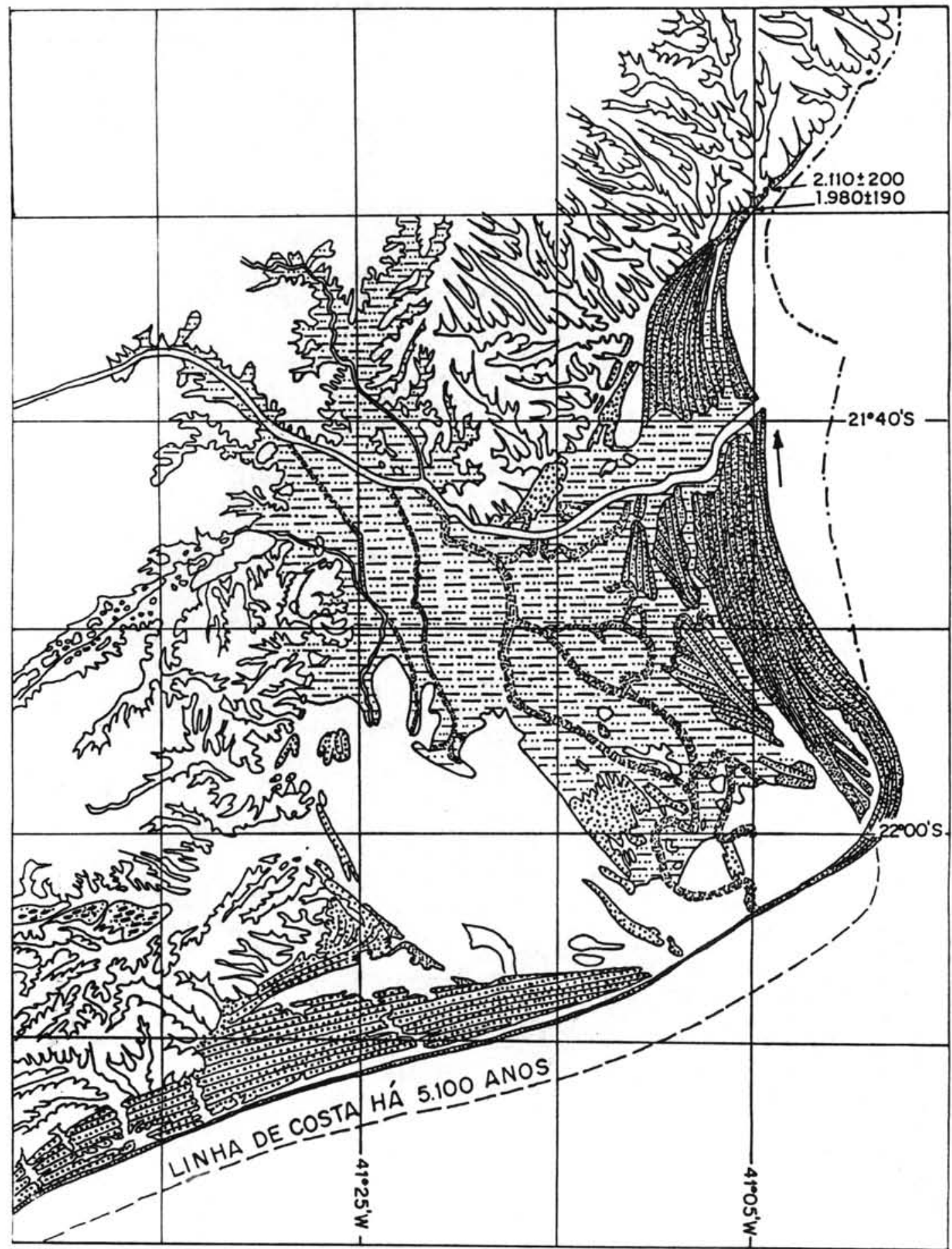

Figura 74 - Subestádio E-4A: Início de uma nova fase de construção sob condições hidrodinâmicas geradas por ondas do setor sul no intervalo de tempo correspodente a 2.500 - 0 anos A.P. 


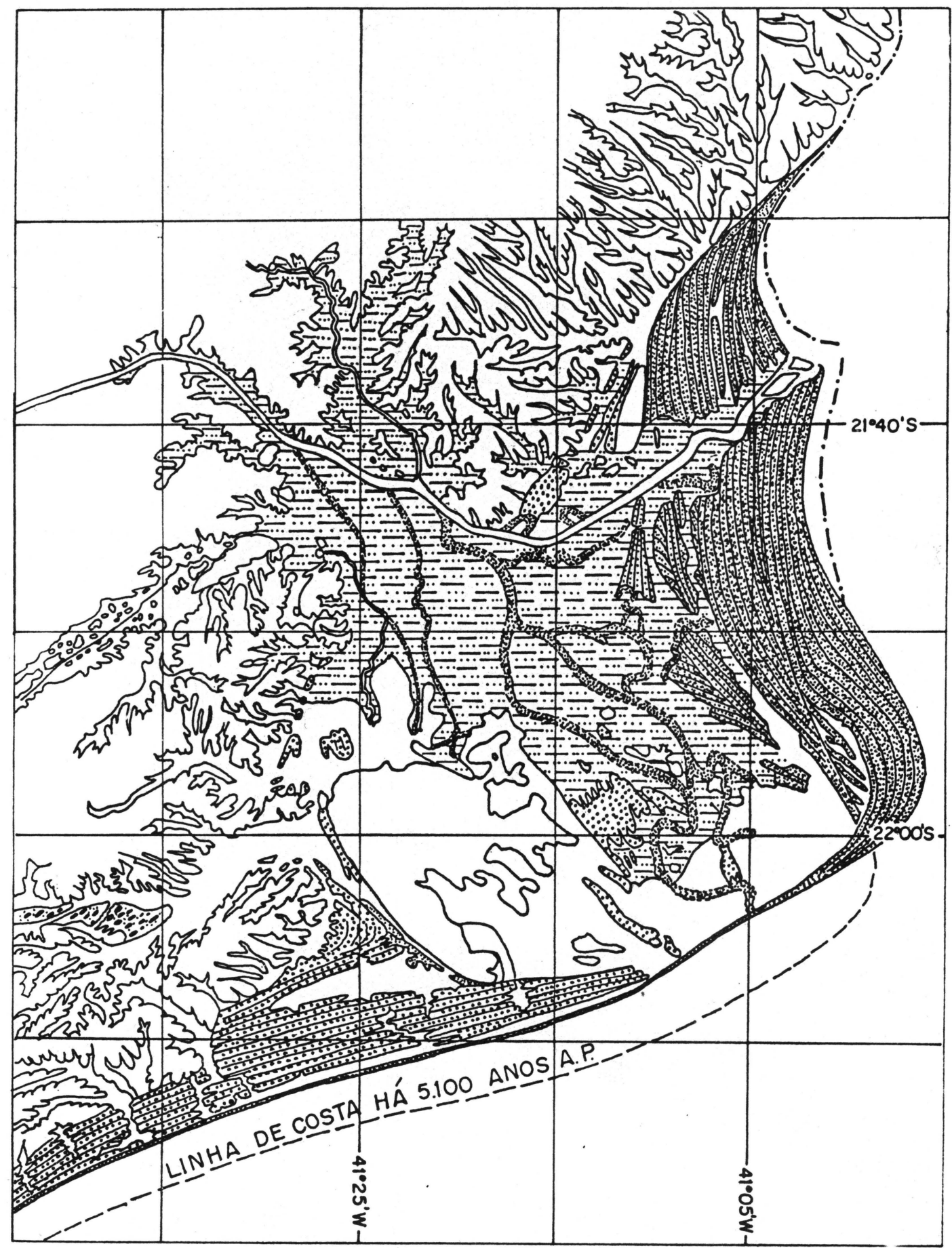

Figura 75 - Subestádio E-4B: Fim da fase de construção no intervalo de tempo correspondente a 2.500 - 0 anos A.P. 


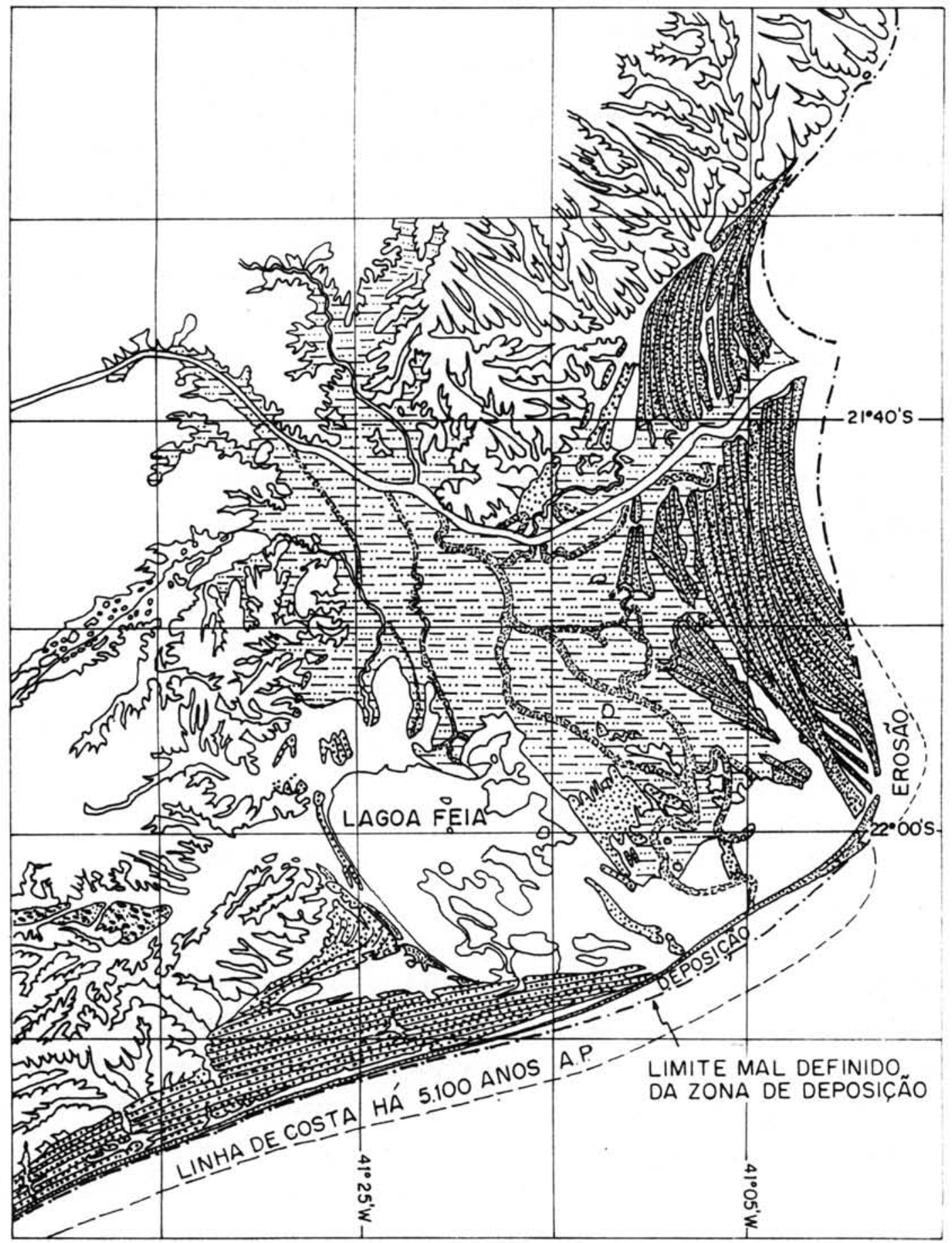

Figura 76 - Subestádio E-5: Fase de erosão acelerada no intervalo de tempo correspondente a 2.500 - 0 anos A.P. 
Subestádio E-6: Retomada da progradação em condições hidrodinâmicas de ondas eficazes do setor sul. As areiais ao sul do Cabo de São Tomé foram erodidas no estádio precedente e transportadas para o norte contribuindo para a rápida progradação da porção sul da desembocadura. É interessante verificar que, contrariamente ao que aconteceu no decorrer do estádio E-5, a progradação foi muito pouco importante na região do Cabo de São Tomé.

c) Dinâmica da desembocadura nas condições hidrodinâmicas geradas por transporte litorâneo do sul para o norte

O modelo de bloqueio intermitente do transporte litorâneo pelo fluxo de um curso fluvial, apresentado no capítulo 3.3 (Fig. 10), pode ser adequadamente ilustrado pelo Rio Paraíba do Sul, pois um estudo pormenorizado das vizinhanças da desembocadura atual (Fig. 77) permitiu evidenciar os seguintes fatos:

- Existência de acentuada assimetria entre as margens sul e norte da foz. A parte sul, mais desenvolvida, é formada pela acreção de cristas praiais essencialmente arenosas, enquanto que a parte norte, menos desenvolvida, é formada por alternância de faixas arenosas separadas por zonas areno-argilosas orgânicas.

- Ocorrência, na porção sul, de um esporão arenoso cuja construção tem sido acompanhada de erosão litorânea acelerada, com destruição de várias casas em Atafona. Entre 1956 e 1976 a linha de praia recuou $100 \mathrm{~m}$ nesta localidade. Em fevereiro de 1976, que coincidiu com um período de alta descarga fluvial, o esporão arenoso foi destruído e começou a construção de um novo esporão que em cinco anos atingiu $300 \mathrm{~m}$ de comprimento (DIAS, 1981) (Fig. 78).

- Existência de feixes de cristas praiais escalonadas, separadas entre si por superfície de discordância, originada durante as fases erosivas que acompanham a formação dos esporões arenosos.

Para testar este modelo foi realizado um estudo sedimentológico que constou essencialmente de análises morfométricas de areias. Os graus de arredondamento foram determinados na fração entre 0,5 e $1 \mathrm{~mm}$ pois, segundo CAIUEUX \& TRICART (1959), partículas com diâmetro em torno de $0,7 \mathrm{~mm}$ são as mais representativas para detecção de eventuais diferenças entre amostras. Inicialmente foram consideradas cinco classes de arredondamento (anguloso, subanguloso, subarredondado, arredondado e muito arredondado), cujas conclusões foram ratificadas utilizando-se apenas três classes (anguloso, subanguloso a subarredondado e arredondado a muito arredondado). Para este estudo foram coletadas 21 amostras de areias de praias atuais entre Macaé (limite sul da planície) e Guaxindiba (limite norte) e 3 amostras do leito atual do Rio Paraíba do Sul.

Os resultados, representados em histogramas (Fig. 79), indicaram a existência de dois grupos de areias que apresentam graus de arredondamento muito diferentes. De Macaé a 


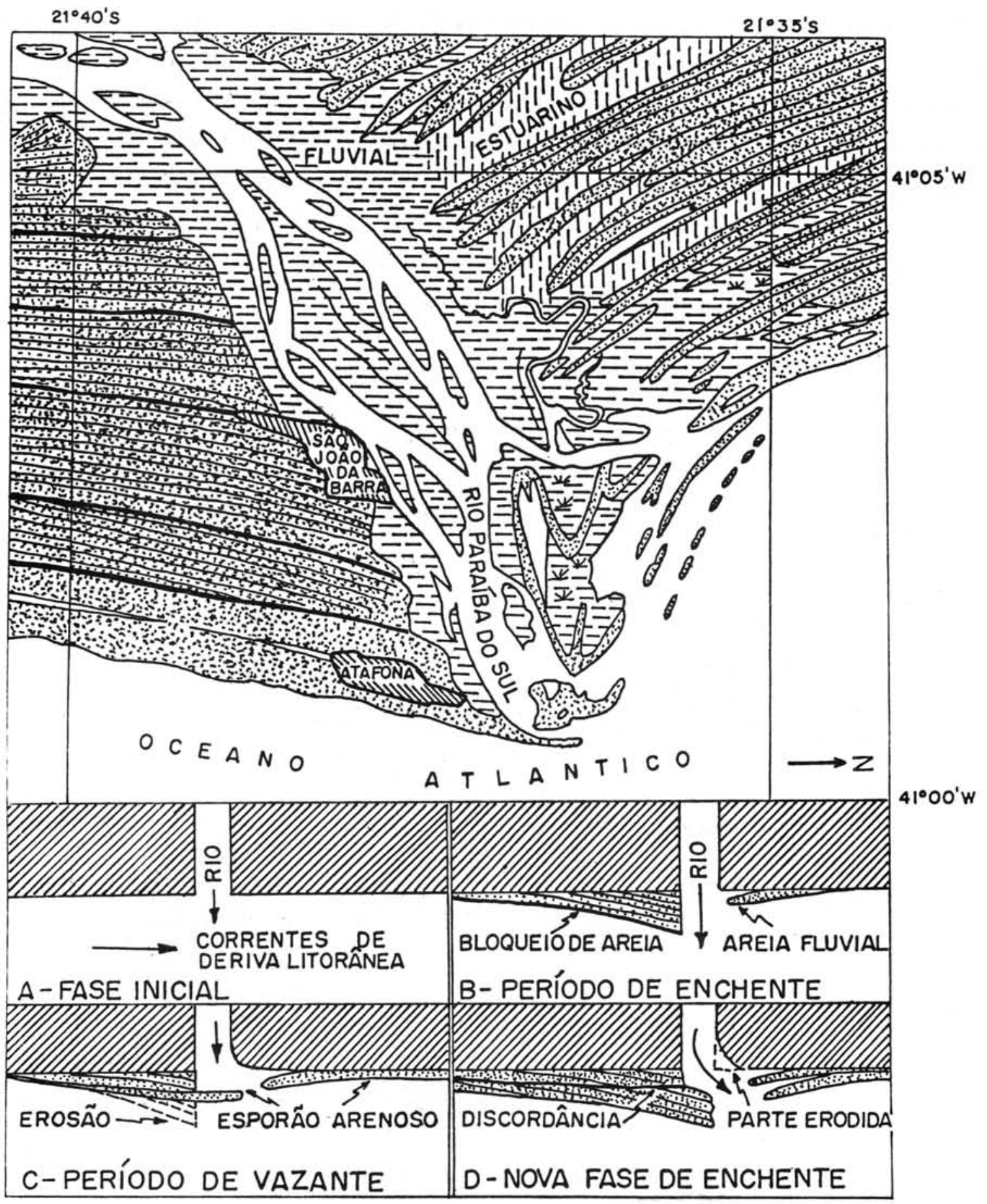

Figura 77 - Desembocadura do Rio Paraíba do Sul mostrando a acentuada assimetria nas cristas praiais das duas margens e o mecanismo de bloqueio das areias supridas por correntes de deriva litorânea dirigidas do sul para o norte. 
Grussal, as areias são caracterizadas pela presença de 20 a $60 \%$ de grãos muito arredondados, sendo o resto formado por grãos arredondados a subarredondados. Da desembocadura à Guaxindiba, as areias são caracterizadas pela ausência de grãos muito arredondados e pela presença de grãos subangulosos, que podem representar até $35 \%$ do conjunto. Finalmente, uma comparação dos histogramas da porção norte da planície costeira com os das três amostras coletadas no leito atual do rio mostra que há grande semelhança. Em Atafona, muito próximo à desembocadura, as areias exibem características intermediárias. Isto se deve, provavelmente, ao fato de que durante a amostragem tenham atuado também ondas do setor nordeste.
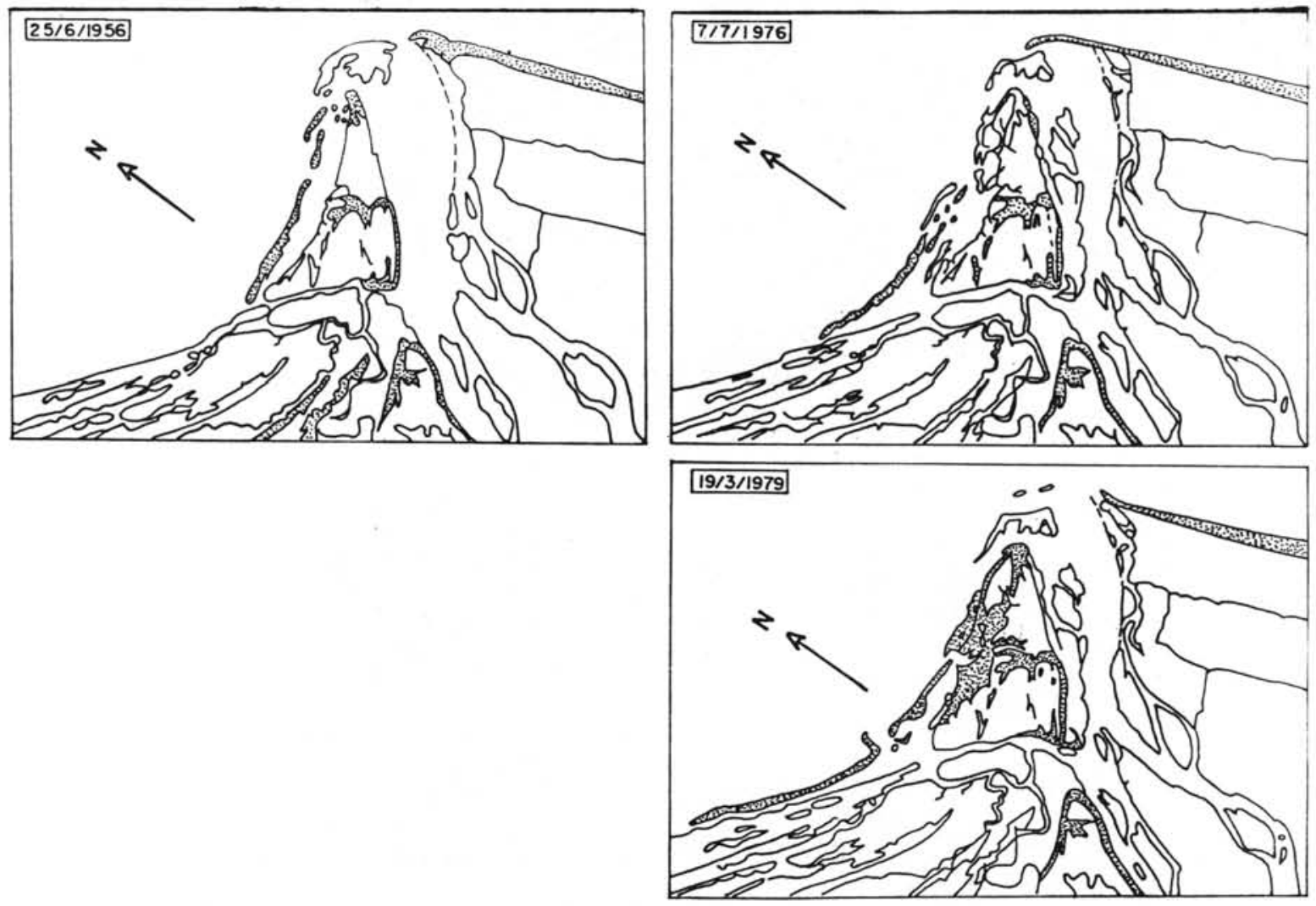

Figura 78 - Modificações nas características morfológicas da foz atual do Rio Paraiba do Sul entre os anos de 1956 e 1979 (DIAS, 1981). 


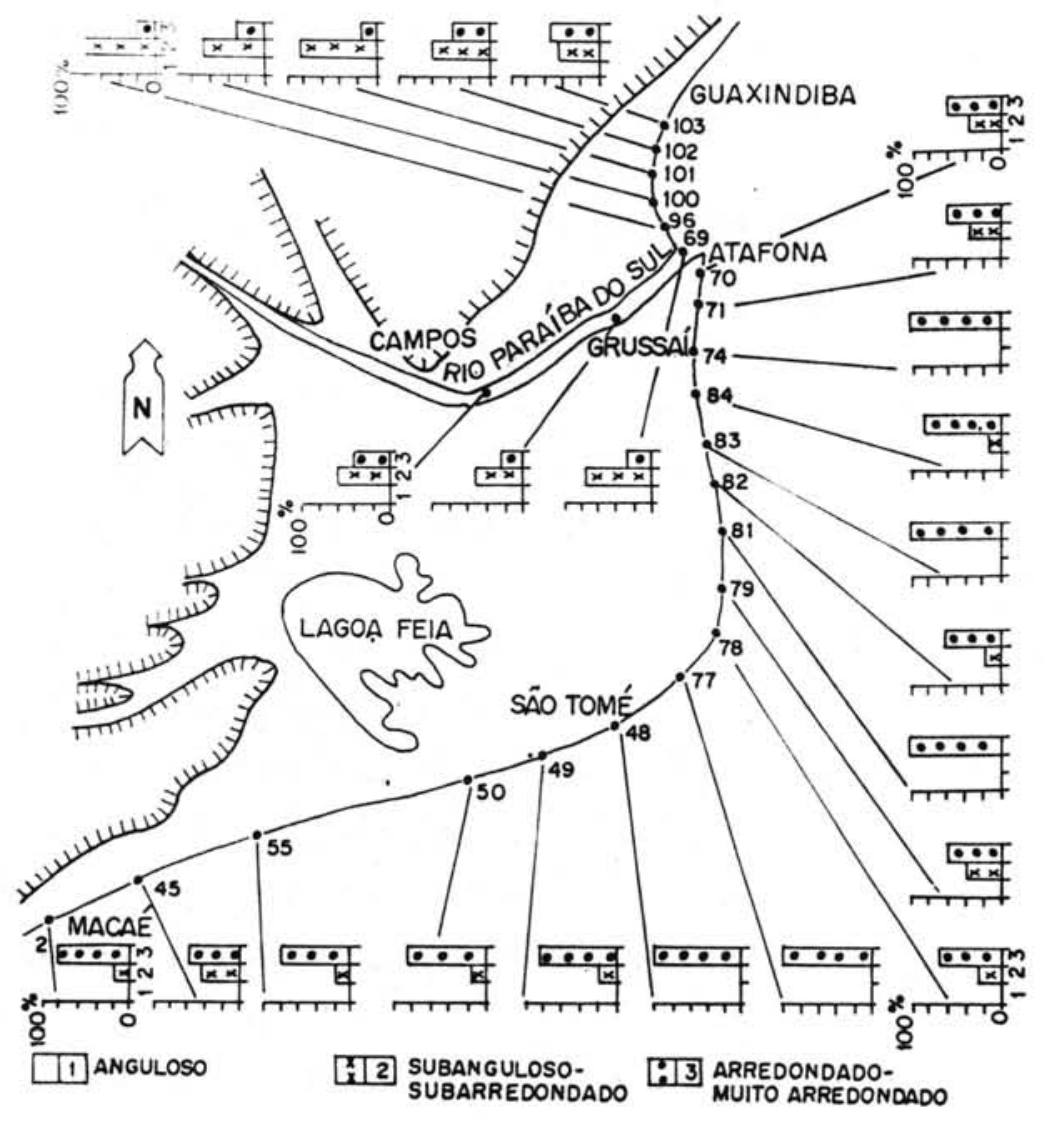

Figura 79 - Características dos graus de arredondamento de areias de praiais atuais e do leito. fluvial do Rio Paraíba do Sul medidos no intervalo entre 0,5-1 mm (três classes de arredondamento) segundo MARTIN et al. (1985b).

\section{d) Considerações gerais}

Como no caso do Rio Doce, parece que a condição essencial para que a planície costeira do Rio Paraíba do Sul seja considerada como um "clássico delta dominado por ondas" não foi satisfeita. De fato, durante este período os sedimentos transportados pelo Rio Paraiba do Sul foram retidos em uma extensa laguna, onde foram usados na construção de um grande delta intralagunar (delta do tipo Mississippi da reconstrução paleogeográfica de LAMEGO, 1955). Além disso, a partir do momento em que Rio Parafba do Sul passou a fluir diretamente para o oceano, as areias depositadas ao largo de sua desembocadura parecem ter sido transportadas essencialmente para o norte. Por outro lado, a maior parte dos depósitos arenosos situada ao sul da desembocadura não foi carreada pelo rio, como foi possível demonstrar também pelas características morfométricas dos grãos de quartzo. 
Conseqüentemente, parece que a planície costeira do Rio Paraíba do Sul também não pode ser enquadrada na categoria de um "clássico delta dominado por ondas, como freqüentemente tem sido feito até o momento.

\subsection{Planície costeira sem delta intralagunar}

\subsubsection{Planicie costeira do Rio Jequitinhonhs (BA)}

\subsubsection{Aspectos gerais}

A planície costeira do Rio Jequitinhonha está situada no sul do Estado da Bahia, ocupando uma área de cerca de $800 \mathrm{~km}^{2}$, com um comprimento na direção norte-sul de $90 \mathrm{~km}$ e uma largura máxima na direção leste-oeste de 29 km (Fig. 80).

Esta planície é abastecida por águas pluviais captadas em uma superfície de $103.067 \mathrm{~km}^{2}$, dos quais $69.997 \mathrm{~km}^{2}$ pertencem à bacia do Rio Jequitinhonha $\theta 38.070 \mathrm{~km}^{2}$ à bacia do Rio Pardo. A descarga média anual do Jequitinhonha, para o período $1943-1969$, foi de $434 \mathrm{~m}^{3} / \mathrm{s}$ na cidade de Jacinto, MG (UNESCO, 1971). Medidas de descarga do Rio Pardo, para o período $1972-$ 1975, forneceram um valor médio anual de $60 \mathrm{~m}^{3} / \mathrm{s}$ na cidade de Mascote, BA (CEPLAB, 1979).

O clima da região é do tipo Af (Köppen), representativo de floresta tropical, quente e úmido sem estação seca (GALVÃO \& NIMER, 1965; GOUVEIA, 1970). A temperatura média anual é de $25^{\circ} \mathrm{C}$, sendo no verão superior a $26^{\circ} \mathrm{C}$ e no inverno variando entre 22 e $24^{\circ} \mathrm{C}$. Como na foz dos rios Doce e Paraíba do Sul, os ventos predominantes provêm de ENE e SSE, sendo os últimos relacionados às passagens de frentes frias que atingem periodicamente a reglăo no outono e inverno.

Embora não se disponha de informações estatisticamente representativas sobre a procedência das frentes de ondas, todas as evidências indicam a existência de ondas de ENE e SSE. O Fenômeno El Niño deve também perturbar os sistemas de ventos e de ondas.

As marés na região apresentam características semidiurnas. Não se conhecem dados de marés na região, mas no porto de Malhado (Ilhéus, BA), $115 \mathrm{~km}$ ao norte, a amplitude média da maré de sizígia é de $1,9 \mathrm{~m}$ e a de maré de quadratura de $0,8 \mathrm{~m}$.

\subsubsection{Geomorfologia}

GOUVEIA (1970) caracterizou na área as seguintes províncias geomorfológicas (Fig. 80): a) Região Serrana, b) Tabuleiros Terciários e c) Planície Quaternária.
a) Região Serrana
O relevo desta área, relacionado aos metassedimentos do Grupo Pardo que, segundo PEDREIRA (1971), seria de idade eopaleozóica, é bastante movimentado, sendo composto por morros e cristas dissimétricas com orientação geral NW-SE (GOUVEIA, op.cit.). 


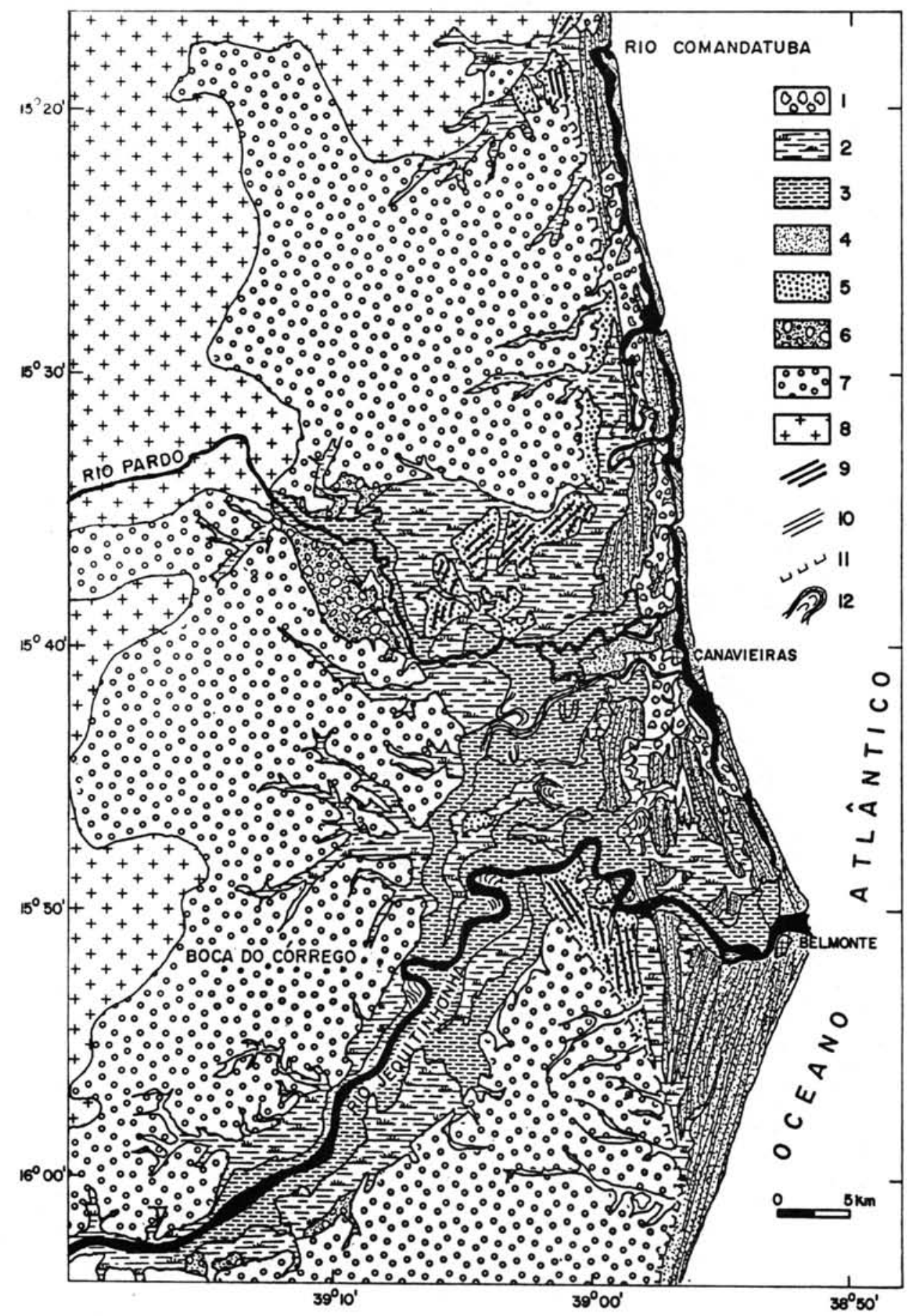

Figura 80 - Mapa geológico esquemático da planície costeira do Rio Jequitinhonha (BA): (1) depósito de manguezal, (2) depósito paludial, (3) terraço fluvial, (4) terraço marinho holocênico, (5) terraço marinho pleistocênico, (6) leques aluviais pleistocênicos, (7) Formação Barreiras, (8) embasamento cristalino précambriano, (9) alinhamentos de cristas praiais pleistocênicas, (10) alinhamentos de cristas praiais holocênicas, (11) "falésia morta" e (12) paleocanais fluviais. 


\section{b) Tabuleiros Terciários}

Este relevo é ligado à Formação Barreiras e apresenta altitudes variáveis entre 50 a $100 \mathrm{~m}$. A rede de drenagem que se instalou sobre esta superfície possui um padrão misto, entre dendritico e paralelo, com interflúvios planos. Os vales fluviais são mais ou menos colmatados e apresentam fundos chatos. A passagem para a planície quaternária processa-se através de uma linha de "falésias mortas", esculpidas durante a Transgressão Antiga (BITTENCOURT et al., 1979b).

\section{c) Planície Quaternária}

Esta província é caracterizada por extensos terraços marinhos de idades pleistocênica e holocênica. Deve-se ressaltar aqui as diferenças apresentadas entre as porções norte e sul da planície costeira. A porção norte é caracterizada por grande variedade de formas de acumulações costeiras, incluindo pântanos, terraços marinhos e fluviais e manguezais. A porção sul é constituída quase que somente por terraços marinhos que, nas vizinhanças da cidade de Belmonte, alcançam quase $15 \mathrm{~km}$ de largura. Separando os terraços pleistocênicos dos holocênicos ocorrem zonas baixas ocupadas por sedimentos flúvio-lagunares.

\subsubsection{Depósitos Quaternários (Fig. 80)}

a) Areias marinhas pleistocênicas

Esses terraços são encontrados em contato com as falésias esculpidas em sedimentos da Formação Barreiras. Bons afloramentos ocorrem na margem direita do Rio Jequitinhonha, onde bancos de areia muito alva que, devido a sua altura, não são recobertos pelos sedimentos do dique marginal daquele rio. Na superfície desses terraços são ainda visiveis os alinhamentos das cristas praiais, que se acham parcialmente obliterados. Sobre esses terraços são também encontrados vestígios de uma antiga rede de drenagem, já colmatada e onde atualmente existem inúmeros pântanos.

b) Areias marinhas holocênicas

Os terraços marinhos holocênicos foram depositados na fase final da última transgressão e durante a regressão subseqüente. São mais freqüentes do que os pleistocênicos e são separados destes por uma zona baixa ocupada por sedimentos flúvio-lagunares. Estruturas sedimentares típicas de face praial e de antepraia são comuns nesses depósitos e acham-se realçadas pelas intercalações de lâminas pouco demarcadas de minerais pesados opacos.

c) Depósitos lagunares

Separando os terraços marinhos pleistocênicos dos holocênicos ocorrem zonas mais baixas, freqüentemente ocupadas por sedimentos lagunares. Devem ter sido formados durante o pico positivo máximo da última transgressão mas, em geral, não são visíveis em superfície por se acharem recobertos por depósitos de turfas. 
d) Depósitos fluviais

São constituídos por sedimentos de diques marginais, de barras de meandros $\theta$ de canais abandonados que jazem em discordância erosiva sobre os terraços marinhos. Além dos terraços fluviais ligados ao atual rio, foram reconhecidos testemunhos de terraços fluviais relacionados a antigos leitos ocupados pelo Rio Jequitinhonha durante os últimos $\mathbf{5 . 0 0 0}$ anaos. Os terraços fluviais associados ao Rio Pardo são inexpressivos talvez porque a carga sedimentar do rio é também muito pequena.

ө) Depósitos paludiais

Os depósitos paludiais são representados por sedimentos turfosos que ocupam áreas de antigas lagunas, zonas alagadiças entre cristas praiais e fundos colmatados de vales escavados sobre a Formação Barreiras, além de planícies de inundação fluvial.

\section{f) Depósitos de manguezais}

Nas desembocaduras abandonadas pelo rio e seus distributários, ou em regióes protegidas pela presença de ilhas arenosas desenvolvem-se os manguezais. Eles estão praticamente restritos à porção da planície situada ao norte da desembocadura atual.

\subsubsection{Evolução paleogeográfica}

a) Trabalhos prévios

Talvez o primeiro trabalho a mencionar a sedimentação quaternária na área é de BACOCCOLI (1971), que classificou a planície costeira do Rio Jequitinhonha como a de um"delta do tipo altamente destrutivo, dominado por ondas". Mas o mapa de BACOCCOU (op.cit., Fig. 81) exibe muitas imprecisões no que diz respeito à distribuição dos terraços arenosos e à direção de alinhamentos de cristas praiais. Deste modo, esta classificação foi posta, em dúvida por DOMINGUEZ (1982) e DOMINGUEZ et al. (1981b, 1983).

\section{b) Modelo proposto neste trabalho}

Em grandes traços, os oito estádios principais correspondentes aos que foram descritos para a evolução paleogeográfica quaternária entre Macaé (RJ) e Maceió (AL) foram reconhecidos. Porém, no caso do Rio Jequitinhonha, foi possivel detalhar e subdividir o oltavo estádio em cinco sub-estádios (Figs. 82, 83, 84).

$1^{\circledR}$ estádio - Corresponde à sedimentação da Formação Barreiras, que ocorreu sob condições de paleoclima semi-árido e nivel relativo do mar abaixo do atual (Fig. 82A).

$2^{2}$ estádio - Sob clima úmido, a porção externa da Formação Barreiras foi erodida durante uma transgressão antiga anterior a de 123.000 anos A.P. Em duas zonas se encontram testemunhos da falésia original esculpida em sedimentos da Formação Barreiras por ocasião do máximo desta transgressão (Fig. 82B). 


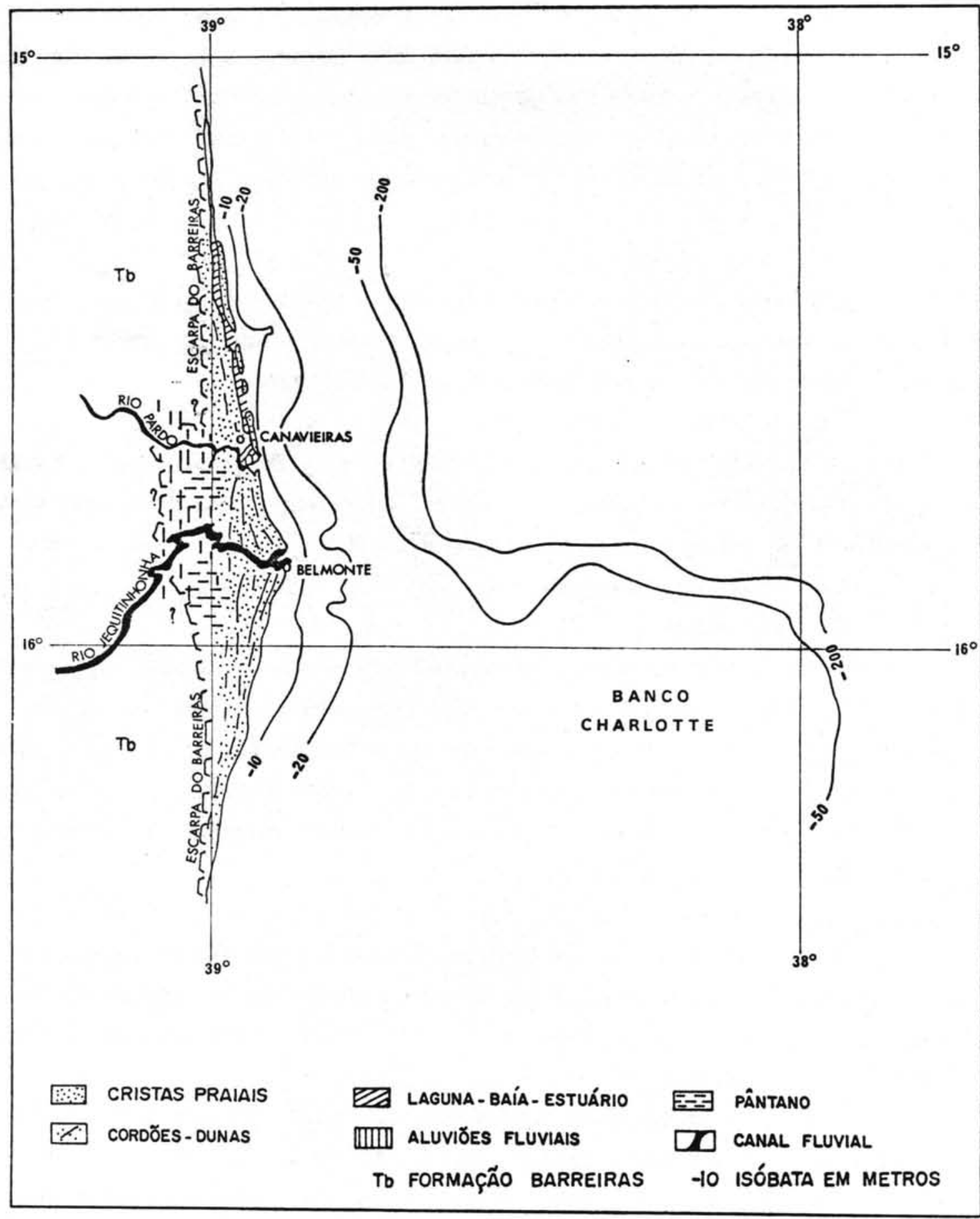

Figura 81 - Mapa geológico esquemático do "delta" do Rio Jequitinhonha segundo BACOCCOL (1971). 

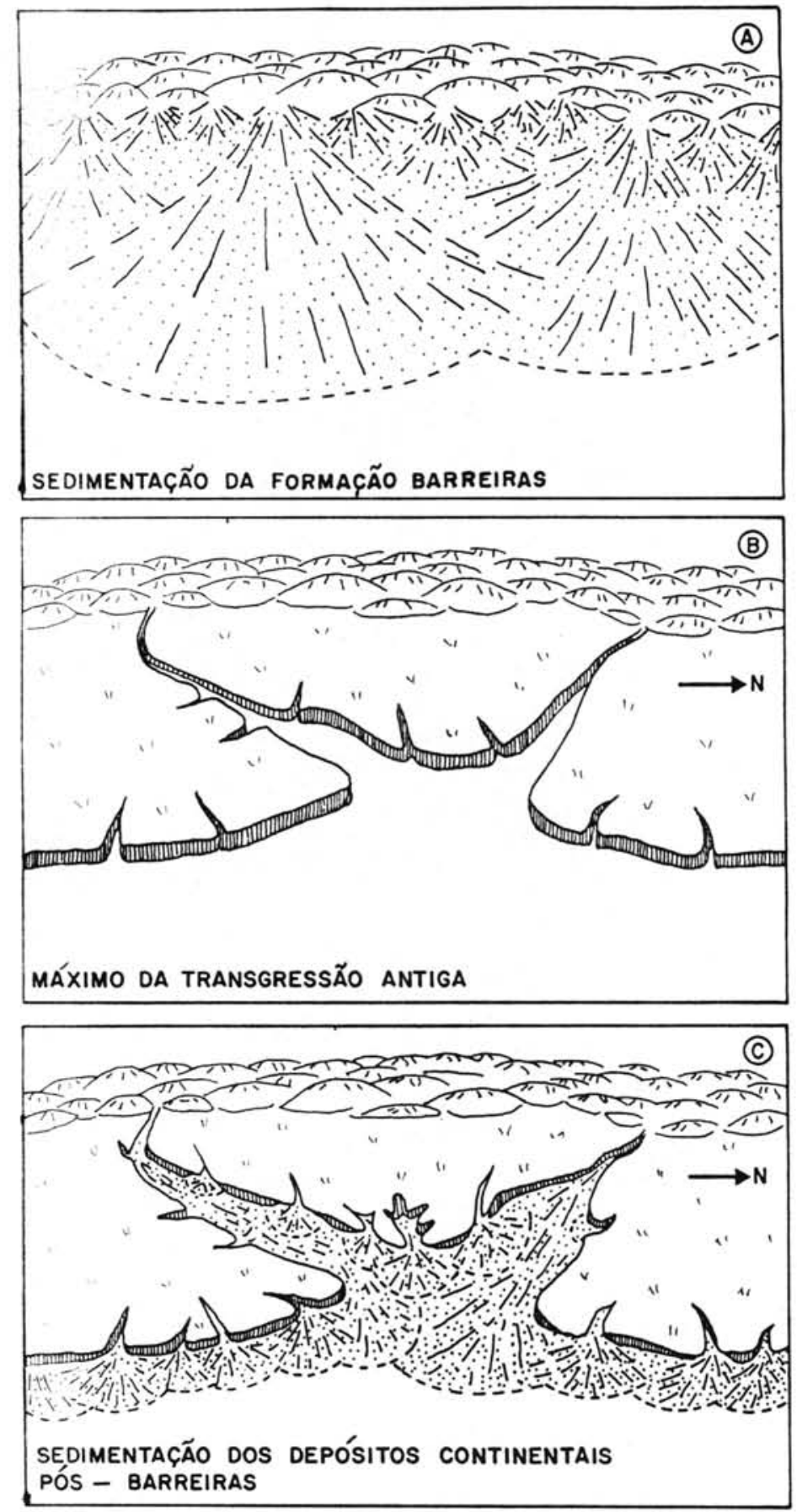

Figura 82 - Esquemas evolutivos da planície costeira do Rio Jequitinhonha do fim do Terciário (sedimentação de leques coalescentes da Formação Barreiras) até o Pleistoceno (antes de 123.000 anos A.P.) segundo DOMINGUEZ (1982). 

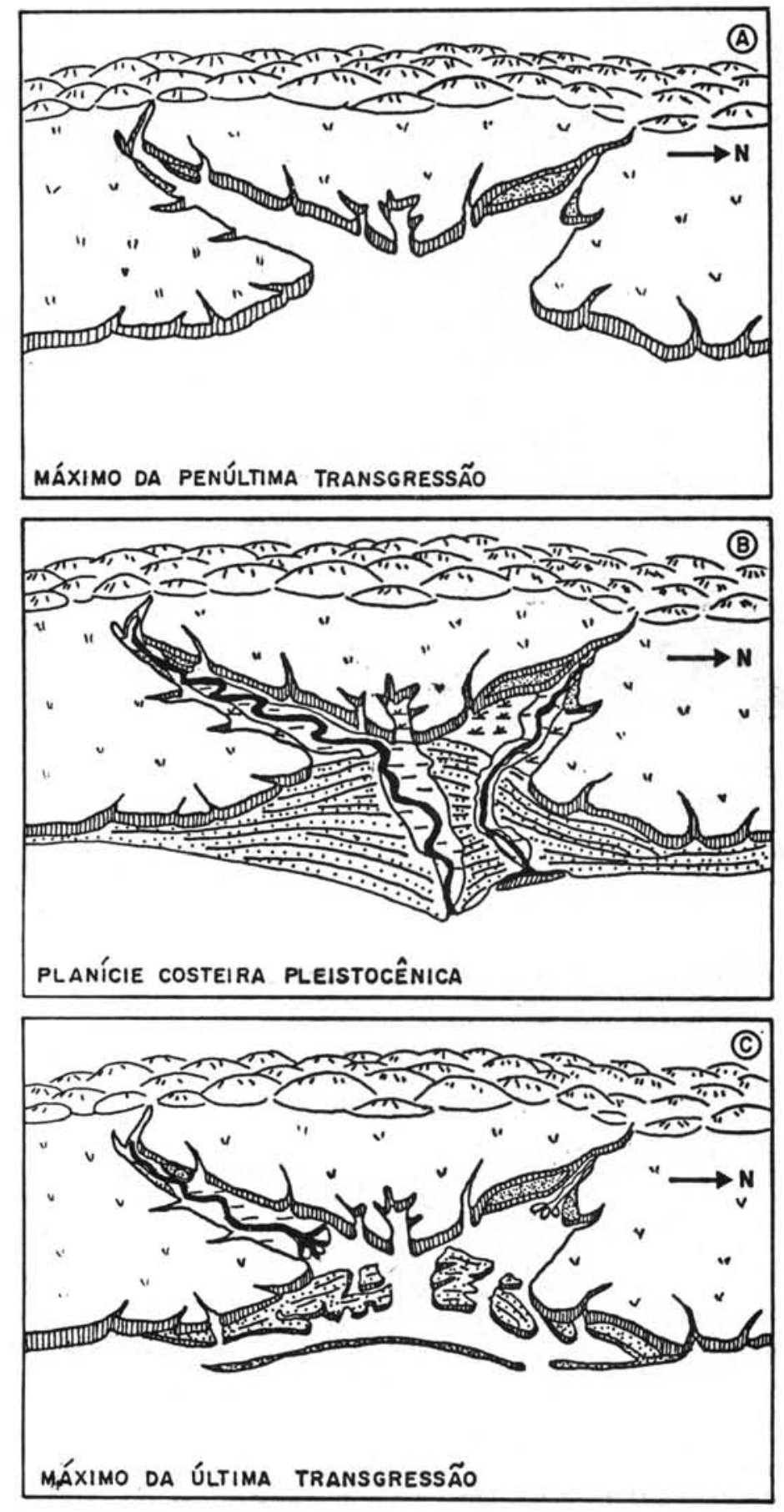

Figura 83 - Esquemas evolutivos da planície costeira do Rio Jequitinhonha do máximo da Penúltima Transgressáo (123.000 anos A.P.) até o máximo da Última Transgressão (5.100 anos A.P.) segundo DOMINGUEZ (1982). 

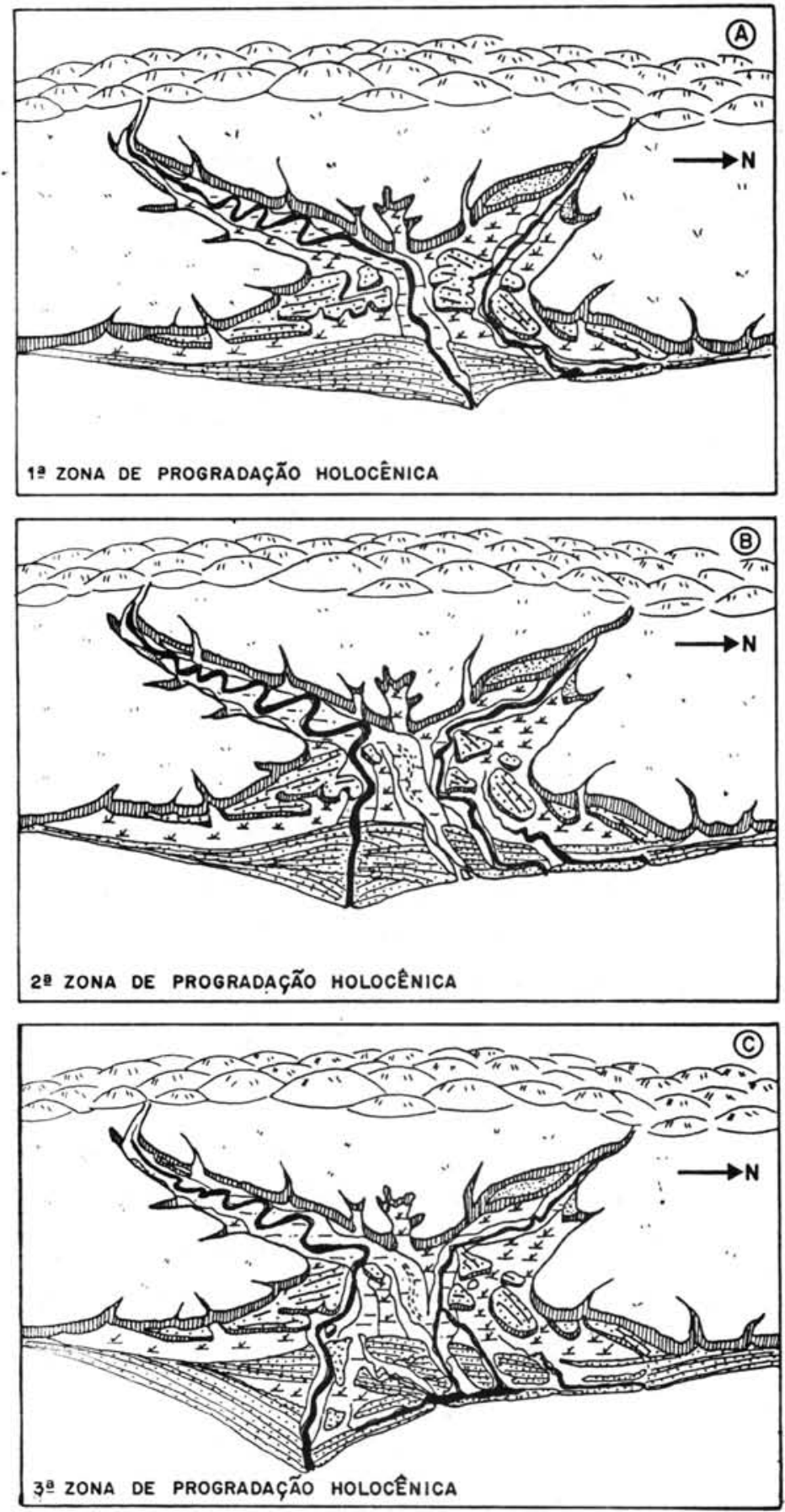

Figura 84 - Esquema evolutivos da planície costeira do Rio Jequitinhonha durante o Holoceno entre 5.100 - 0 anos A.P. (DOMINGUEZ, 1982). 
$3^{\circ}$ estádio - Corresponde à disposição de sedimentos continentais, na forma de leques aluviais coalescentes, no sopé das falésias esculpidas na Formação Barreiras durante o evento transgressivo anterior. Esta sedimentação ocorreu também sob condições climáticas semi-áridas (Fig. $82 \mathrm{C})$.

$4^{2}$ estádio - Durante a Penúltima Transgressão (123.000 anos A.P.), a maior parte dos depósitos continentais do $3^{2}$ estádio foi erodida, ficando preservados apenas nas cabeceiras dos vales escavados nos sedimentos da Formação Barreiras pelos rios Pardo e Jequitinhonha. Nos locais onde o mar conseguiu erodir totalmente os leques aluviais pleistocênicos, as ondas retrabalharam a linha de falésia esculpida durante a Transgressão Antiga. Esta linha de falésia delimita o contato entre a Formação Barreiras e a planície costeira. Nesta fase, os vales dos rios Pardo e Jequitinhonha, bem como os demais vales entalhados na Formação Barreiras, foram afogados (Fig. 83A).

$5^{2}$ estádio - Durante a regressão que se seguiu à Penúltima Transgressão formaram-se planícies costeiras pleistocênicas com características semelhantes às das planícies holocênicas. Testemunhos deste evento encontram-se preservados, tanto ao norte quanto ao sul do Rio Jequitinhonha, na forma de terraços arenosos geralmente mais altos do que os terraços holocênicos (Fig. 83B).

$6^{\circ}$ estádio - Durante a parte final da última transgressão, que se estendeụ entre 7.000 e 5.100 anos A.P., a planície costeira pleistocênica foi parcialmente destruída e afogada. A rede de drenagem que havia se instalado sobre os terraços marinhos pleistocênicos, favorecida pela descida acentuada do nivel de base no período anterior, fol afogada, da mesma maneira que alguns dos vales escavados na Formação Barreiras. Os vales dos rios Pardo e Jequitinhonha foram, nesta ocasião, também invadidos pelo mar formando estuários dentro dos quais esses rios iniciaram a construção de pequenos deltas.

Associada ao afogamento da planície costeira pleistocênica, houve a formação de ilhas-barreiras, atrás das quais ficaram protegidos os tetemunhos restantes dos terraços pleistocênicos e uma laguna (Fig. $83 \mathrm{C}$ ). Amostras de conchas de moluscos e fragmentos de madeira, coletadas de sedimentos lagunares, indicaram que as ilhas-barreiras já estavam formadas antes do máximo da transgressão, conforme se vê na lista abaixo:

$\begin{array}{lcc}\text { Número da amostra } & \begin{array}{c}\text { Idade radiocarbono } \\ \text { (anos A.P.) }\end{array} & \text { Referência de laboratório } \\ \text { B-335 } & 6.180 \pm 140 & \text { Bah-814 } \\ \text { B-438 } & 5.850 \pm 150 & \text { Bah-910 } \\ \text { B-447 } & 5.570 \pm 150 & \text { Bah-915 } \\ \text { B-366 } & 5.300 \pm 140 & \text { Bah-822 }\end{array}$


$7^{\circ}$ estádio - Devido ao espaço bastante reduzido entre as ilhas-barreiras e os terraços pleistocênicos e/ou falésias entalhadas na Formação Barreiras, a fase de delta intralagunar é praticamente inexistente e o Rio Jequitinhonha parece ter alcançado rapidamente o oceano.

$8^{2}$ estádio - As fases sucessivas de emersão, entre $5.100-3.900,3.600-2.800$ e 2.500 - hoje, deixaram evidências facilmente discerniveis sobre esta planície costeira. Foi possivel estabelecer correlações entre os diferentes sistemas de cristas praiais holocênicas e as diferentes fases de emersão. A partir de um estudo da orientação e da morfologia das cristas praiais na superfície dos terraços holocênicos, associado a idades radiocarbono, DOMINGUEZ (1982) reconheceu a ocorrência de três sistemas de cristas praiais relacionadas às três desembocaduras sucessivas do Rio Jequitinhonha durante os últimos 5.000 anos. Além disso, identificou três faixas distintas de depósitos fluviais associadas às três desembocaduras, separadas entre si por zonas baixas e pantanosas.

Subestádio 8A (Fig. 83A) - Corresponde à fase de emersão ocorrida entre 5.100 e 3.900 anos A.P., que foi registrada pela construção do primeiro sistema de cristas praiais. Estas cristas estariam relacionadas a uma antiga foz do Rio Jequitinhonha, que se situava pouco ao sul da atual cidade de Canavieiras. Um fragmento de madeira coletado de sedimentos lagunares recobertos pela crista praial mais interna, possivelmente correspondente à ilha-barreira, foi datado em $5.850 \pm 150$ anos A.P. (Bah-910), mostrando que o primeiro sistema de cristas praiais deve ter sido formado após esta época.

Subestádio 8B - Este evento está relacionado ao período de submersão ocorrido entre 3.800 e 3.600 anos A.P. Em consequeência deste evento transgressivo, a primeira zona de progradação holocênica foi parcialmente erodida e afogada, ao mesmo tempo em que a instabilidade produzida pela elevação do nivel de base forçaria a migração da desembocadura do Rio Jequitinhonha à procura de situação de maior eficiência. O fenômeno envolvido neste processo parece ter sido do tipo avulsão, pois os terraços cobertos de alinhamentos de cristas praiais existentes entre as duas desembocaduras não foram destruldos (Fig. 84B).

Subestádio $8 \mathrm{C}$ - Corresponde ao período de emersão que ocorreu entre $3.600 \mathrm{e}$ 2.900 anos A.P. quando, como conseqüência, foi construída a segunda zona de progradação (Fig. 84B).

Subestádio 8D - Entre 2.700 e 2.500 anos A.P., o nível do mar subiu novamente e com isso ocorreu a destruição parcial e o afogamento da planície costeira, sendo os seus efeitos até hoje visíveis sobre fotografias aéreas (Fig. 85). Toda a porção central da zona de progradação acha-se atualmente ocupada por sedimentos finos, que sustentam um ambiente paludial. Esses sedimentos recobrem parcialmente as cristas praiais atribuindo-lhes feições típicas de afogamento. TRICART \& CARDOSO DA SILVA (1968) reconheceram esta zona afogada e atribuiram-lhe origem tectônica. 

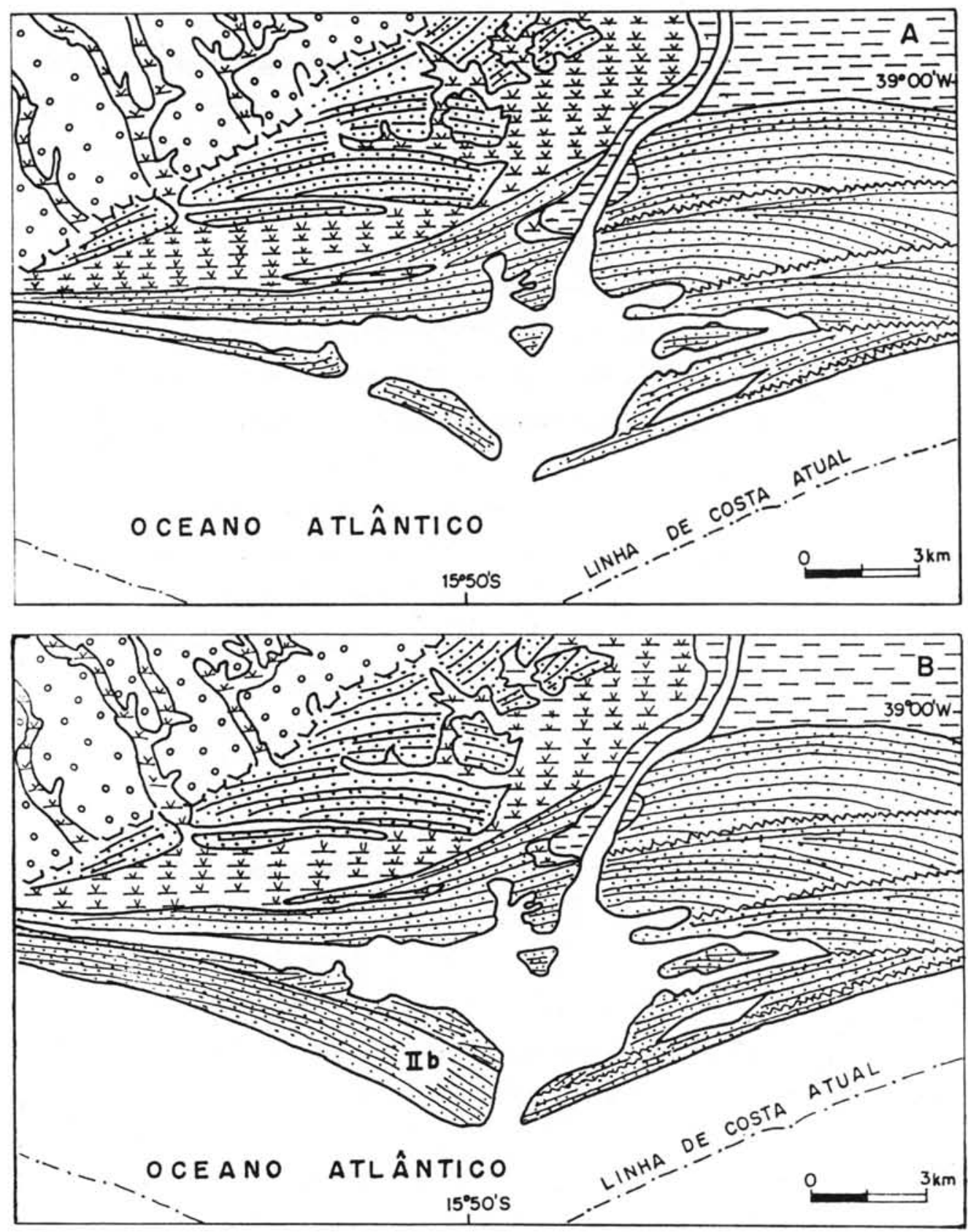

Figura 85 - (A) Paleogeografia durante o afogamento da segunda zona de progradação holocênica do Rio Jequitinhonha. (B) Após o afogamento a linha de costa ainda teve condições de progradar rumo ao mar, principalmente ao sul da desembocadura do Rio Jequitinhonha, quando entáo foi construído o subsistema de cristas praiais IIb (DOMINGUEZ, 1982). 
O afogamento da segunda zona de progradação holocênica gerou situação de instabilidade que afetou o equillbrio fluvial que culminou com novo processo de avulsão, desiocando o Rio Jequitinhonha mais para o sul, quando o rio passou a ocupar o leito atual dando início à terceira zona de progradação (Fig. 84C).

A datação de um fragmento de madeira proveniente de uma camada com restos vegetais intercalados na porção interna do terceiro sistema de cristas praiais indicou uma idade de $2.570 \pm 100$ anos A.P. (Bah-907). Portanto, provavelmente a mudança de desembocadura para a posição atual ocorreu entre 2.700 e 2.500 anos A.P., como conseqüência do evento transgressivo que ocorreu nesta época.

Subestádio 8E - Representa a fase de emersão produzida após 2.500 anos A.P., que deu origem ao terceiro sistema de cristas praiais (Fig. $84 \mathrm{C}$ ). Duas outras amostras coletadas em cristas praiais forneceram as seguintes idades : $1.800 \pm 160$ anos A.P. (Bah-817) e I.770 1100 anos A.P. (Bah-820). Nenhuma amostra proveniente da terceira faixa de sedimentos fluviais forneceu uma idade superior a 2.500 anos A.P., como se pode ver abaixo:

\begin{tabular}{lcc} 
Número da amostra & $\begin{array}{c}\text { Idade radiocarbono } \\
\text { (anos A.P.) }\end{array}$ & $\begin{array}{c}\text { Referêncla de laboratório } \\
\text { B-325 }\end{array}$ \\
B-345 & $2.240 \pm 100$ & Bah-811 \\
B-327 & $1.800 \pm 100$ & Bah-817 \\
B-441 & $1.700 \pm 100$ & Bah-812 \\
B-436 & $1.420 \pm 100$ & Bah-911 \\
B-339 & $1.400 \pm 100$ & Bah-909 \\
B-359 & $1.350 \pm 100$ & Bah-821 \\
B-433 & $1.350 \pm 100$ & Bah-810 \\
B-442 & $1.070 \pm 100$ & Bah-908 \\
B-445 & $1.040 \pm 100$ & Bah-912 \\
B-429 & $790 \pm 100$ & Bah-916 \\
B-431 & $610 \pm 100$ & Bah-905 \\
B-336 & $580 \pm 100$ & Bah-906 \\
B-444 & $520 \pm 100$ & Bah-815 \\
B-428 & $400 \pm 100$ & Bah-914 \\
\hline
\end{tabular}


Uma vez que não existem terraços fluviais mais expressivos associados ao Rio Pardo, desconhece-se o papel desempenhado por este rio nos diversos estádios evolutivos da planicle costeira. Provavelmente, este rio sempre desempenhou um papel secundário, alcançando o mar por detrás de ilhas arenosas, como ocorre hoje em dia, ou após divagar paralelamente à costa.

c) Discordâncias nos alinhamentos de cristas praiais devidas a causas não relacionadas a variações de nivel relativo do mar.

Ainda que não tenham sido feitos estudos tão detalhados quanto os realizados nas planícies costeiras dos rios Doce e Paraíba do Sul, é possivel evidenciar algumas discordâncias nos três sistemas de terraços holocênicos da planície costeira do Rio Jequitinhonha (Fig. 86). Parecem ter ocorrido três períodos importantes de erosão nos sistemas de cristas praiais formados entre 2.500 anos A.P. e hoje. Estas fases de erosão não parecem estar relacionadas à elevação do nivel do mar, mas são devidas à inversão, no sentido de atuação das ondas eficazes, como também aconteceu muitas vezes nas planícies costeiras dos rios Doce e Paraiba do Sul.

d) Considerações gerais

Como a laguna existente por detrás das ilhas-barreiras era bastante pequena, o Rio Jequitinhonha já deveria sair diretamente ao oceano por ocasião do máximo transgressivo holocênico há 5.100 anos A.P. Contrariamente ao que ocorreu nos rios Doce e Parafba do Sul, os aportes sedimentares do Rio Jequitinhonha contribuiram então na construção da primeira geração de cristas praiais holocênicas. Portanto, a condição essencial ("depósito edificado a partir de aportes fluviais") para que a planície costeira do Rio Jequitinhonha seja considerado como "delta dominado por ondas" parece estar satisfeita. Entretanto, quando se examina a distribuição das areias de ambos os lados da desembocadura constata-se, como na desembocadura do Rio Parafba do Sul, que existe uma acentuada dissimetria. Os depósitos arenosos situados ao sul da desembocadura são formados por uma acreção lateral regular de cristas praiais, enquanto que ao norte existe uma alternância de depósitos arenosos e de zonas baixas ocupadas por manguezais. Como no caso da planície costeira do Rio Paraíba do Sul, as areias de terraços situados ao sul da foz não foram supridas pelo rio. É interessante notar que esta dissimetria não existe no mapa de BACOCCOL (op.cit.), conforme se vê na Figura 81, talvez porque tal assimetria não seria condizente com um "delta dominado por ondas"!

Conseqüentemente, mesmo que a história evolutiva da planície costeira do Rio Jequitinhonha seja parcialmente diferente dos rios Doce e Parafba do Sul, ainda, a rigor, não se pode considerá-lo como um "clássico delta dominado por ondas". 


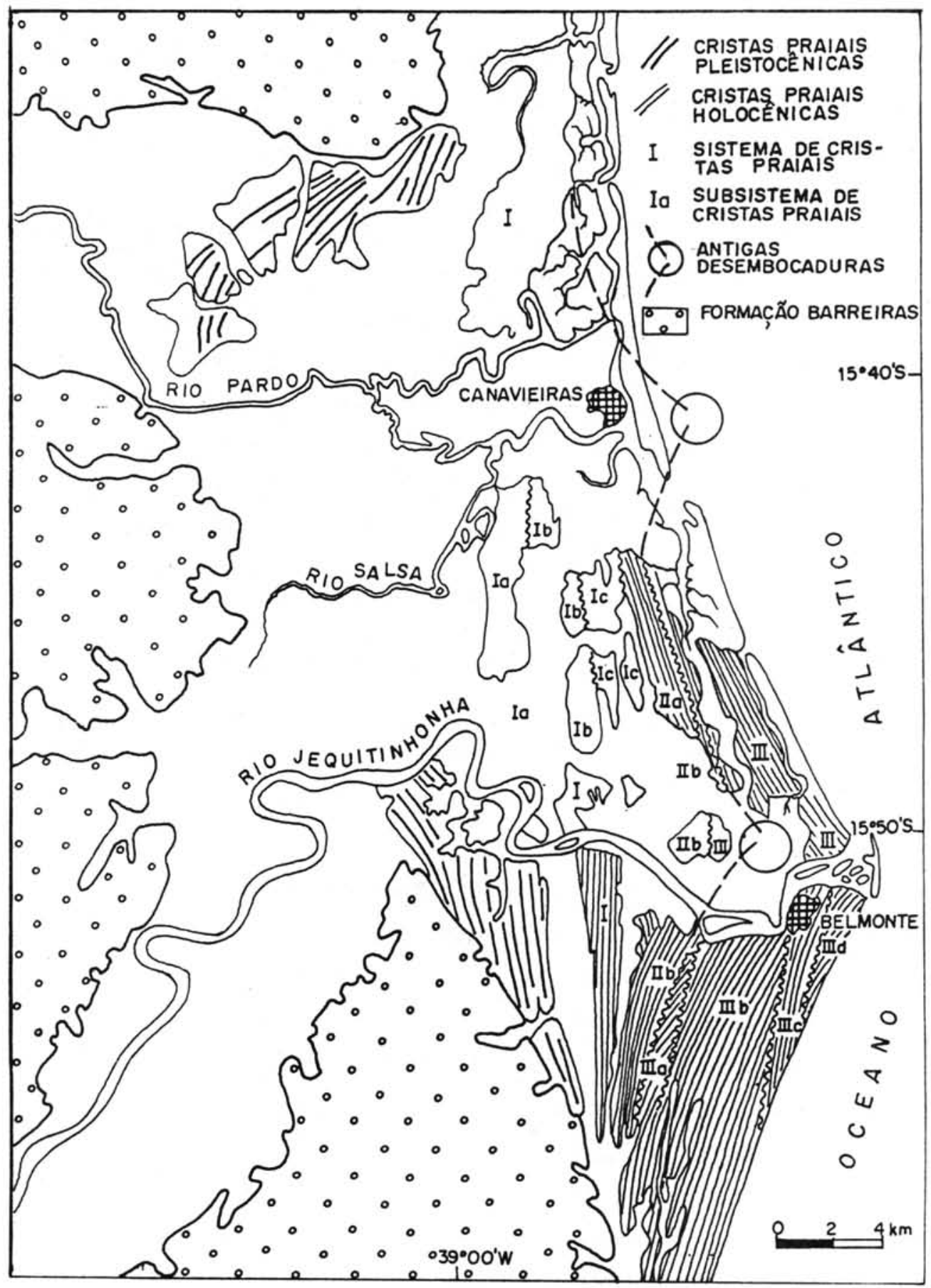

Figura 86 - Discordâncias secundárias nos três sistemas de terraços holocênicos (DOMINGUEZ, 1982). 


\subsubsection{Planície costeira do Rio São Francisco (SE/AL)}

\subsubsection{Aspectos gerais}

A planície costeira do Rio São Francisco exibe uma forma aproximadamente triangular medindo $25 \times 60 \mathrm{~km}$ e ocupando uma área de cerca de $750 \mathrm{~km}^{2}$. Ela está situada no limite entre os estados de Sergipe e Alagoas sobre a bacia cretácea que recebe os nomes desses dois estados (Fig. 87).

O Rio São Francisco estende-se entre $09^{\circ} 00^{\prime}$ e $20^{\circ} 00^{\prime}$ de latitude sul, através de aproximadamente $2.700 \mathrm{~km}$, drenando uma área de $630.000 \mathrm{~km}^{2}$. É um rio com regime tropical típico caracterizado por um período de enchente ligado às chuvas de verão e um período de vazante relacionado à época de menor pluviosidade. A descarga média deste rio é de $3.300 \mathrm{~m}^{3} / \mathrm{s} \mathrm{na} \mathrm{foz.} \mathrm{O}$ clima da planície costeira do Rio São Francisco é do tipo AS' de acordo com KÖPPEN (1948), quente com temperatura do mês mais frio superior a $18^{\circ} \mathrm{C}$, mês mais seco com precipitações inferiores a 60 $\mathrm{mm}$ e verão seco. Na região costeira, as chuvas ocorrem quase que exclusivamente no inverno (abril e junho) com ventos de SE, enquanto que no resto do tempo predominam os ventos de NE (COUTINHO, 1970).

As marés apresentam um regime semidiurno e não se conhecem as suas amplitudes na foz. Porém, no porto de Maceió (AL) a amplitude média de sizígia é de 2,2 m e no porto de Aracaju (SE) de 2,1 m. Nas imediações da foz, a corrente superficial é predominantemente dirigida para SSW, induzida pelos ventos de NE, que também formam ondas que incidem a ângulo agudo em relação à linha de praia e geram corrente de deriva litorânea para o sul.

\subsubsection{Geomorfologia}

PONTE (1969) reconheceu três províncias geomorfológicas com características semelhantes às regióes ocupadas pelas planícies costeiras anteriormente descritas, que são : a) Zona de relevo ondulado, b) Tabuleiros Terciários e c) Planície Quaternária.

a) Zona de relevo ondulado

Está relacionada às rochas pré-cambrianas dos grupos Baixo São Francisco e Sergipe, onde as diferenças litológicas são responsáveis pelas variações na morfologia do terreno.

b) Tabuleiros Terciários

Os extensos tabuleiros da Formação Barreiras formam uma superfície plana e pouco dissecada. A drenagem da área é feita por vales jovens ou rejuvenescidos, com perfil em " $\mathrm{V}$ ", que entalham profundamente os sedimentos e chegando, às vezes, a expor as formações sotopostas. Os vales maiores são caracterizados por fundos chatos, margens abruptas e cursos inferiores ocasionalmente ocupados por lagunas. 


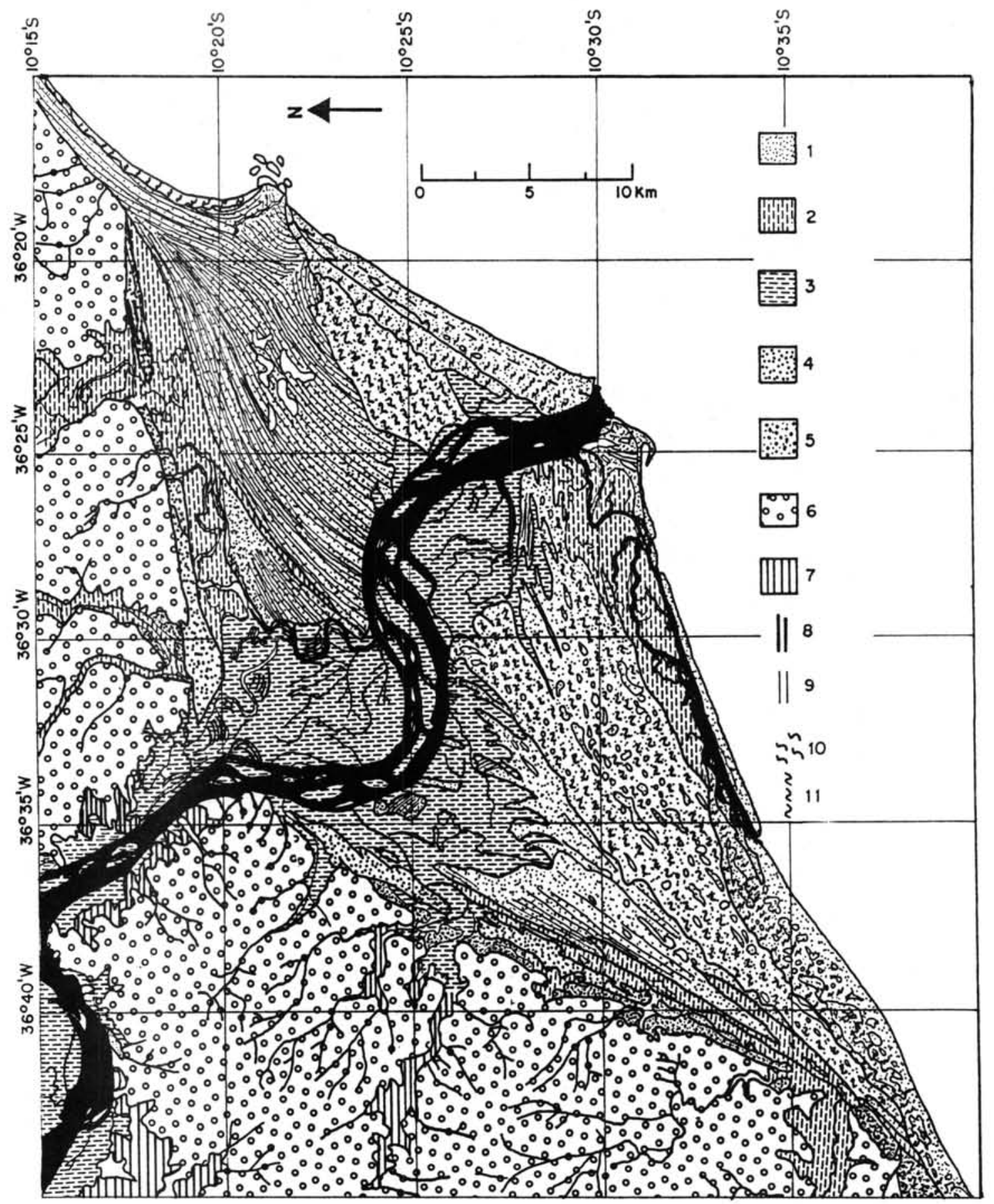

Figura 87 - Mapa geológico esquemático da planície costeira do Rio Săo Francisco (SE/AL): (1) terraço marinho holocênico, (2) sedimentos lagunares, (3) sedimentos fluviais, (4) terraço marinho pleistocênico, (5) sedimentos continentais pós-Barreiras, (6) Formação Barreiras, (7) depósitos mesozóicos e paleozóicos, (8) alinhamentos de cristas praiais pleistocênicas, (9) alinhamentos de cristas praiais holocênicas, (10) dunas fixadas e (11) dunas ativas. 
c) Planície Quaternária

Esta unidade geomorfológica é formada por depósitos de origem marinha, lacustre e eólica. A planície é atravessada por um canal fluvial ativo, que contêm barras arenosas migrantes $\theta$ ilhas no seu leito. Sobre as partes mais elevadas da planície distribuem-se dunas eólicas de diferentes idades.

\subsubsection{Depósitos Quaternários (Fig. 87)}

Os depósitos quaternários desta planície foram estudados em diferentes escalas por BACOCCOU (1971), Figura 88, COLEMAN \& WRIGHT (1972, 1975), Figura 89 e BRAZ FILHO (1980). Esses primeiros trabalhos constam de mapas em pequena escala, onde são esboçadas as distribuições espaciais das fácies sedimentares constituídas de dunas eólicas, cristas praiais, aluviões e depósitos de pântanos. No mapa de COLEMAN \& WRIGHT (op. cit.), mesmo considerando-se a pequena escala, aparecem imprecisões muito grandes e, apesar disso, tem sido freqüentemente utilizado por outros autores, resultando em interpretações falsas da história evolutiva desta planície costeira. Entre essas imperfeições têm-se as seguintes: a) o limite interior da planície está demarcado incorretamente diminuindo a área em cerca de $20 \%$, b) ao longo de todo o litoral da porção sul são cartografadas dunas enquanto que, na verdade, quase metade desta área corresponde a manguezais, c) não existe, na realidade, a planície de inundação da extremidade da metade sul mapeada pelos autores e d) a orientação das cristas praiais, assinalada na metade norte, que vai transversalmente de encontro às escarpas da Formação Barreiras, não corresponde à situação real.

Após um trabalho sistemático, seguindo a mesma técnica adotada em outros setores do litoral brasileiro, foram reconhecidos os seguintes tipos de depósitos sedimentares (Fig. 87):

a) Depósitos de leques aluviais coalescentes

Esses depósitos são compostos de areias mal selecionadas, com argilas e seixos, praticamente inconsolidados e de cor esbranquiçada. As características sedimentológicas e a situação geomórfológica desses depósitos, sempre juntos ao sopé de escarpas da Formação Barreiras com a superfície inclinada para a planície, permitem atribuítos a depósitos de leques aluviais coalescentes pós-Barreiras. Podem ser diferenciados dos terraços marinhos pleistocênicos que são mais baixos e apresentam um contato mais abrupto com os sedimentos da Formação Barreiras, além de exibirem características sedimentológicas diferentes e, além disso, não podem ser confundidos com os terraços fluviais, não somente pelas suas declividades mas também pelas suas propriedades litológicas (VILASBOAS et al., 1985). Entretanto, BRAZ FILHO (op.cit.) mapeou esses materiais, ora como Formação Barreiras, ora como terraços fluviais quaternários.

Na metade sul da planície são bem desenvolvidos e ocorrem quase continuamente, enquanto que ao norte restringem-se a ocorrências isoladas dentro de pequenos vales esculpidos nos sedimentos da Formação Barreiras. 


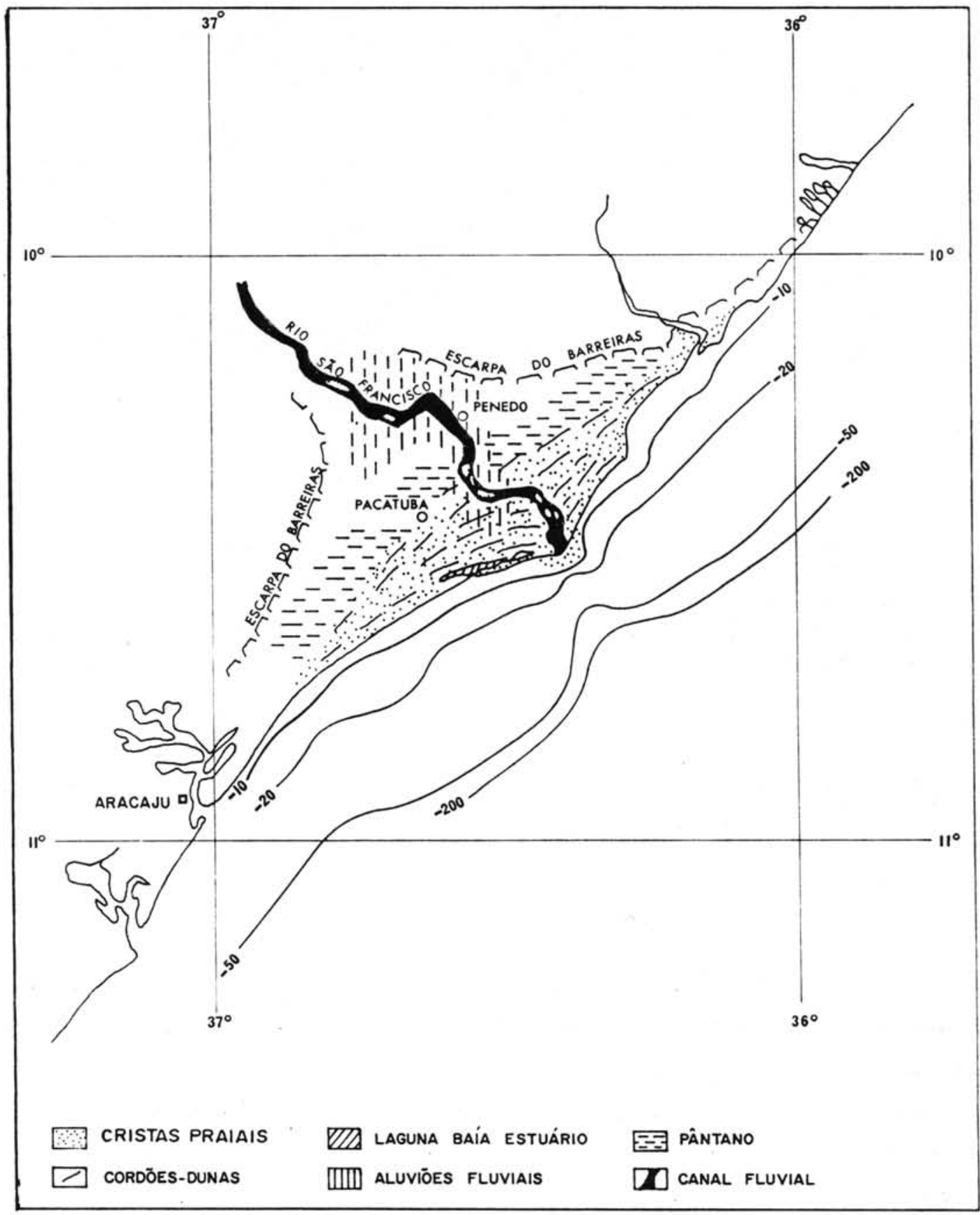

Figura 88 - Mapa geológico do "delta" do Rio São Francisco segundo BACOCCOL (1971). 


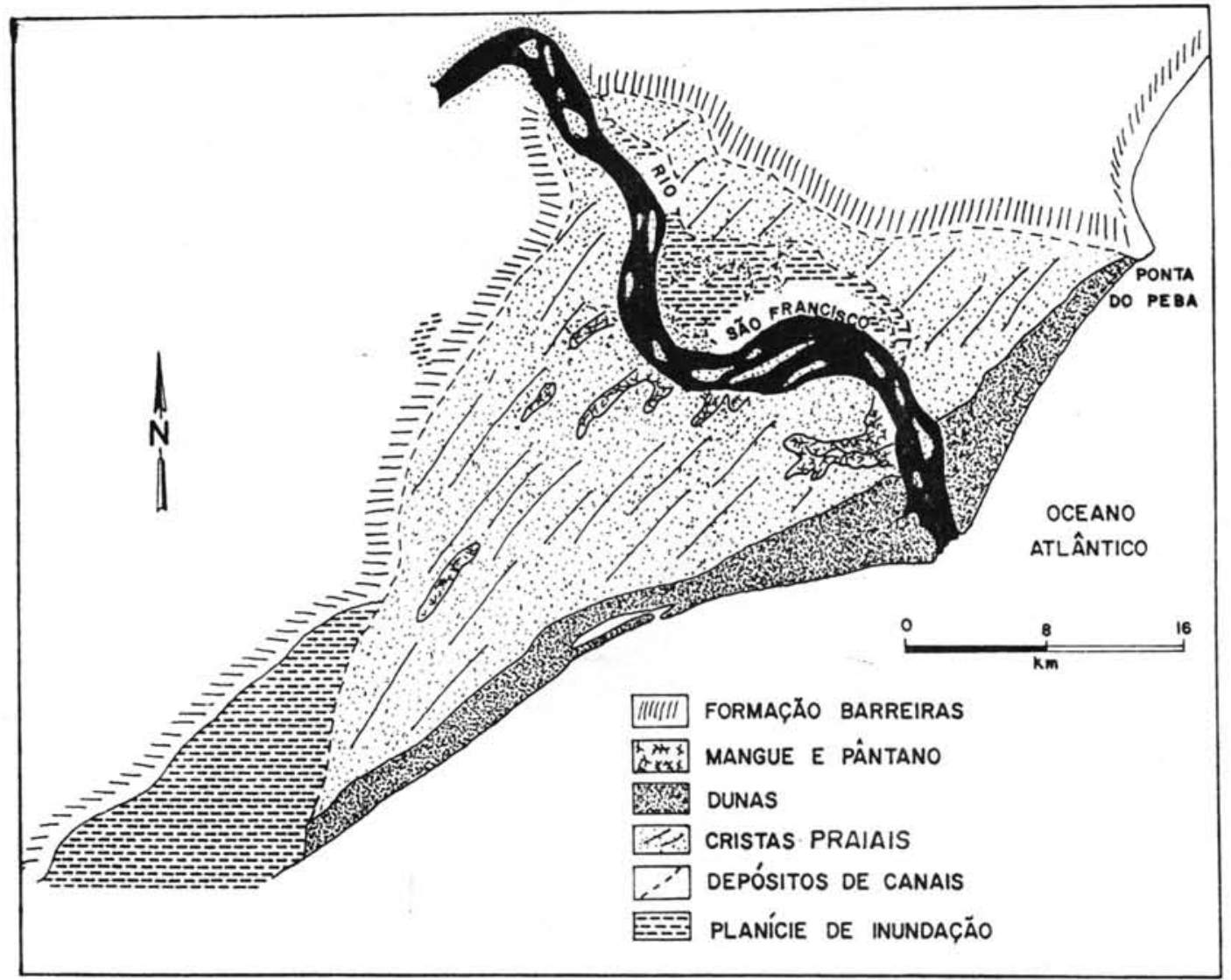

Figura 89 - Mapa geológico esquemático da planície costeira do Rio São Francisco (SE/AL) segundo COLEMAN \& WRIGHT $(1972,1975)$.

b) Areias marinhas pleistocênicas

Ocorrem nas porções mais internas das planícies costeiras formando terraços com 8 a $10 \mathrm{~m}$ de altitude, quase contínuos e interrompidos apenas por alguns cursos fluviais. Os depósitos são essencialmente arenosos mas localmente podem apresentar vários niveis de seixos intercalados em toda a seqüência vertical. Os alinhamentos das cristas praiais, visíveis sobre fotografias aéreas, e as suas relações com a Formação Barreiras permitem atribuir a esses depósitos uma origem marinha pleistocênica.

BRAZ FILHO (op.cit.) mapeou parte desses depósitos, aflorantes na metade sul da planície costeira, como fluviais e depositados segundo o autor, quando o Rio São Francisco teria ocupado um curso paralelo ao litoral. A origem fluvial não é justificada por BRAZ FILHO embora, ao descrevê-los, este autor induza um raciocínio neste sentido, ao mencionar a ocorrência de camadas de 
seixos unicamente na base do terraço, o que seria um argumento em favor de uma origem fluvial. Porém, essas camadas de seixos não estão restritas à base dos terraços $\theta$, além disso, para que o Rio São Francisco tivesse ocupado a posição admitida por BRAZ FILHO, depositando material de fundo de canal na altitude de 8 a $10 \mathrm{~m}$, muito superior à da planície que se estende para o oceano, seria preciso que o nivel de base fosse bem superior ao atual e que houvesse uma elevação próxima e paralela à encosta da Formação Barreiras, na área atualmente ocupada pela planície costeira.

c) Areias marinhas holocênicas

Depósitos arenosos de granulação fina a média, apresentando estratificaçōes plano-paralelas e mergulhando suavemente para o mar, constituem terraços holocênicos com mais de $4 \mathrm{~m}$ de altitude na porção interna e $1 \mathrm{~m}$ na parte externa. Esses terraços são separados dos pleistocênicos por uma zona baixa e alagadiça. Em fotografias aéreas, os alinhamentos das cristas praiais são aqui bem melhor demarcados e muito mais próximos entre si do que nos terraços pleistocênicos.

d) Depósitos eólicos

Ao longo de praticamente toda a porção externa da planície costeira do Rio São Francisco, ocorrem dunas eólicas atribulveis a pelo menos duas gerações: a mais interna, composta de areias mais pedogenizadas e as vezes estabilizada pela vegetação e outra, mais externa formada por dunas móveis contendo lagoas temporárias. Essas dunas podem apresentar 20 a $30 \mathrm{~m}$ de altura, sendo composta de areias finas a muito finas, sendo cinza-amareladas nas mais antigas e amareladas nas mais novas. Elas apresentam freqüentemente formas barcanóides $\theta$ indicam ventos unidirecionais do ENE.

Sobre os terraços pleistocênicos ocorrem raras dunas fixadas pela vegetação. Essas dunas devem ser mais recentes do que 123.000 anos A.P. e, por outro lado, mais antigas do que 5.100 anos A.P., pois elas foram erodidas durante o máximo da transgressão holocênica, sendo deste modo contemporâneas às denominadas dunas externas da região de Salvador (MARTIN et al., 1980c).

Sobre a superfície de tabuleiros da Formação Barreiras, na porção sul da planície costeira, onde COLEMAN \& WRIGHT (op. cit.) cartografaram uma planície de inundação (Fig. 89), existem dunas fixadas pela vegetação. Essas dunas foram construidas por ventos provindos do leste $e$ foram formadas a partir de sedimentos originados de uma antiga planície costeira. $O$ fato de o limite externo deste campo de dunas coincidir exatamente com a linha de falésia da Formação Barreiras, não havendo atualmente nënhuma cobertura arenosa na parte inferior da encosta, sugere que as dunas sejam mais antigas do que a penúltima transgressão que esculpiu esta falésia. Deste modo, embora não se disponha ainda de qualquer evidência mais direta, pode-se admitir que essas dunas tenham provavelmente a mesma idade das dunas internas mapeadas na região de Salvador (MARTIN et. al., 1980c) sendo, portando, mais antigas do que 123.000 anos A.P. 
e) Depósitos lagunares

Ocupando as porções internas da planície costeira entre os terraços marinhos pleistocênicos e holocênicos, bem como preenchendo vales escavados sobre a Formação Barreiras, ocorrem sedimentos areno-argilosos e orgânicos de origem lagunar, parcialmente cobertos por depósitos de turfa. Dois fragmentos de madeira coletados nos depósitos lagunares foram datados em

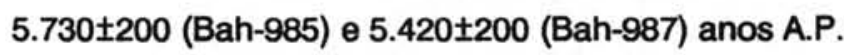

f) Depósitos fluviais

Sedimentos siftico-argilosos, representando principalmente depósitos de transbordamento fluvial, são encontrados nas zonas baixas e planas que margeiam o Rio São Francisco na porção central da planície e ocupando as porções superiores dos vales escavados na Formação Barreiras.

\section{g) Depósitos paludiais}

Nas zonas baixas das paleolagunas, assim como nos fundos de pequenos vales escavados na Formação Barreiras, freqüentemente ocorrem depósitos paludiais representados por turfeiras.

\section{h) Depósitos de manguezais}

Na metade sul da planície costeira, logo após a desembocadura do Rio São Francisco, desenvolve-se uma faixa de manguezais com $5 \mathrm{~km}$ de largura e $25 \mathrm{~km}$ de comprimento. $\mathrm{Na}$ parte norte, não existem manguezais exceto muito localmente. Da mesma maneira, na margem direita do rio, são encontrados depósitos de mangues antigos nas porções mais internas dos depósitos arenosos holocênicos. Um fragmento de madeira coletado dentro desses sedimentos de paleomanguezais foi datado em $4.680 \pm 210$ anos A.P. (Bah-989). Esta idade parece indicar que as diferenças existentes, hoje em dia, entre as porções sul e norte desta planície já existia no início da regressão que seguiu ao máximo de 5.100 anos A.P.

Esta dissimetria entre as porções norte e sul é um elemento essencial para entender a formação da planície costeira do Rio São Francisco. Fol visto anteriormente que COLEMAN \& WRIGHT $(1972,1975)$ cartografaram dunas eólicas em posição simétrica às da porção norte no lugar, de fato, ocupado por estes manguezais. Deste modo desapareceria a assimetria, permitindo classificar erroneamente esta planície como um "clássico delta altamente destrutivo dominado por ondas".

\section{i) Formações recifais}

Na porção norte da planície costeira, junto à localidade de Pontal do Peba, existem bancos recifais formados por algas calcárias e corais. Amostra de coral coletada na superfície foi datada em 4.310 150 anos A.P. (Bah-992). Esta idade está de acordo com as datações obtidas, no 
litoral da Bahia, para a porção superior dos recifes e corresponde ao momento da morte dos organismos recifais em conseqüência do abaixamento de nivel relativo do mar.

A porção interna deste recife acha-se preenchida por areias marinhas holocênicas e a presença desta feição repercutiu na geometria das cristas praiais. Mais ao sul existe um outro recife, quase inteiramente recoberto por dunas eólicas, mas cuja presença é detectada pela geometria das cristas praiais.

\subsubsection{Evolução paleogeográfica}

a) Trabalhos prévios

Nos trabalhos de BACOCCOL (op.cit.), COLEMAN \& WRIGHT (op.cit.) e BRAZ FILHO (op.cit.), a planície costeira do Rio São Francisco foi classificada como "delta dominado por ondas". Foi visto também que, apesar dos equívocos cometidos por COLEMAN \& WRIGHT (op.cit.), o mapa desses pesquisadores têm sido usado por muitos autores.

b) Modelo proposto neste trabalho

Aqui também, a evolução paleogeográfica pode ser explicada pelos oito estádios principais de evolução, que são os seguintes:

$1^{2}$ estádio - Corresponde à deposição dos sedimentos continentais terciários da Formação Barreiras, sob condições de clima semi-árido e nivel relativo do mar abaixo do atual.

$2^{2}$ estádio - Corresponde à fase de erosão da parte externa da Formação Barreiras durante uma transgressão antiga em condições de clima úmido. A falésia original representativa do máximo deste nível marinho mais alto encontra-se preservada na parte sul da planície costeira, mas apresenta-se bastante dissecada.

$3^{2}$ estádio - Fase de deposição de leques aluviais coalescentes no sopé das falésias da Formação Barreiras, previamente esculpidas. Esta deposição processou-se também sob condições de clima mais seco do que o atual. É provável que nesta fase os depósitos tenham sido retrabalhados pelo vento, formando-se dunas construídas por areias provindas da planície costeira, que cavalgaram as falésias da Formação Barreiras.

$4^{2}$ estádio - Época do máximo transgressivo de 123.000 anos A.P., quando o mar erodiu parte dos depósitos de $3^{2}$ estádio, que foram preservados só na porção sul da planície, enquanto que ao norte o mar chegou a retrabalhar as falésias esculpidas pela Transgressão Antiga. Finalmente, os cursos inferiores dos rios foram afogados e transformados em estuários e "rias".

$5^{2}$ estádio - Com o abaixamento de nivel relativo do mar, foram construídos os terraços marinhos pleistocênicos a partir das falésias esculpidas nos sedimentos da Formação Barreiras e dos remanescentes dos depósitos de leques aluviais coalescentes. Durante ou logo após a formação dos terraços marinhos pleistocênicos os ventos retrabalharam parte da superfície, chegando localmente a formar campos de dunas eólicas. 
$6^{2}$ estádio - Corresponde à fase final da última transgressão (7.000 a 5.100 anos A.P.), quando parte dos terraços pleistocênicos foi erodida $\theta$ os vales foram afogados. Dos dois lados da foz do Rio São Francisco, ilhas-barreiras isolaram dois corpos lagunares estreltos. Fragmentos de madeira provenientes dos depósitos desta paleolaguna foram datados em 5.730士200 (Bah-985) e $5.420 \pm 200$ (Bah-987) anos A.P.

$7^{0}$ estádio - Em conseqüência da pequena largura dessas lagunas, como aconteceu no caso do Rio Jequitinhonha, o Rio São Francisco também não teve o espaço necessário à construção de delta intralagunar, contrariamente ao que ocorreu nos rios Doce e Paraiba do Sul.

80 estádio - Corresponde à fase de descida de nivel do mar de 5.100 anos A.P. até hoje, quando as lagunas perderam suas comunicações com o mar, sendo colmatadas e transformadas em pântanos com turfeiras, enquanto sucessivas cristas praiais progradantes eram formadas, iniciando-se nas partes externas das llhas-barreiras. A medida que o mar regredia, o Rio São Francisco divagou ligeiramente pela planicie costeira, erodindo parcialmente os depósitos marinhos holocênicos e depositando, parte de sua carga sedimentar na planície de inundação.

Se bem que nenhum estudo detalhado, como nos casos dos rios Doce e Paralba do Sul, tenha sido feito no Rio São Francisco, parece que aqui não ocorrem discordâncias nos alinhamentos das cristas praiais, em função de modificações nos sentidos de atuação das ondas eficazes. Isto parece bastante lógico, pois as frentes frias atingem muito raramente a foz deste rio e, mesmo quando elas chegam, já estão muito enfraquecidas. Em consequência disso, as ondas eficazes são sempre aquelas provenientes do NE, gerando um transporte litorâneo do norte para o sul. Essas condições hidrodinâmicas parecem ter sido mais ou menos constantes durante a construção da porção holocênica da planície costeira nos últimos 5.100 anos.

c) Considerações gerais

A primeira vista, a planicie costeira do Rio São Francisco pode parecer que corresponda a mais um "delta dominado por ondas". Entretanto, uma observação mais pormenorizada mostra a existência de acentuada assimetria entre os depósitos situados ao norte e ao sul da foz, apesar da modificação do aspecto original dos depósitos por algum retrabalhamento é́lico.

O mecanismo de bloqueio pelo fluxo dos sedimentos transportados do norte para o sul, pelas correntes de deriva litorânea, é muito conspícuo. Este fenômeno é semelhante ao que ocorre na foz do Rio Paraíba do Sul, porém na desembocadura do Rio São Francisco as ondas eficazes provém do $\mathrm{NE}$, de modo que o bloqueio é produzido ao norte da foz. Tudo indica que este bloqueio tenha ocorrido do mesmo modo durante toda a história de construção da planicie costeira. As areias transportadas pelo Rio São Francisco são sempre depositadas ao sul da foz e, então, a metade norte não resultou da contribuição do aporte fluvial. É interessante notar que esta dissimetria 
não é perceptfivel nos mapas do BACOCCOU (op.cit.), Figura 88, nem no de COLEMAN \& WRIGHT (op. cit.), Figura 89 , talvez porque tal assimetria não condiz com um modelo de "delta dominado por ondas".

Não sendo a metade norte derivada de sedimentos de aporte fluvial, mas de origem marinha, a planície costeira da foz do Rio São Francisco também não pode ser considerada como um "clássico delta dominado por ondas".

\subsection{Planície costeira de domínio eólico do Rio Parnafba (PI/MA)}

\subsubsection{Aspectos gerais}

A planície costeira do Rio Parnafba situa-se no limite dos estados de Piaul e Maranhão. Estende-se na direção E-W por mais de $10 \mathrm{~km}$, enquanto que sua dimensão N-S é de cerca de 20 km (Fig. 90)

O Rio Parnalba é um rio perene de $1.414 \mathrm{~km}$ de extensão caracterizado por grandes diferenças entre as descargas de enchente e vazante. Os afluentes da sua margem direita percorrem regiōes semi-áridas e, desta maneira, são na maioria efêmeros. Por outro lado, os tributários da margem esquerda drenam regiöes cuja pluviosidade anual é de 1.250 a $2.000 \mathrm{~mm}$ e, portanto, são perenes.

O clima da planície costeira é úmido a sub-úmido e as precipitações anuais excedem $1.500 \mathrm{~mm}$. Os ventos e as ondas dominantes, provenientes do $\mathrm{NE}$, dão origem às correntes de deriva litorânea dirigidas de leste para oeste.

\subsubsection{Geomorfologia}

Na região adjacente à planície costeira do Rio Parnalba pode-se reconhecer, como na grande maioria das planícies costeiras associadas a desembocaduras fluviais do litoral brasileiro, três províncias geomorfológicas: a) Região Serrana, b) Tabuleiros Terciários e c) Planície Quaternária.

\section{a) Região Serrana}

Caracterizada por áreas aplainadas, onde sobressaem cristas isoladas, constituindo o Maciço Mediano de Granja, composto de migmatitos, gnaisses, granitóides e quartzitos de idade précambriana.

\section{b) Tabuleiros Terciários}

Elevações de topo plano com a superfície suavemente inclinada para o mar são constituidas de sedimentos da Formaçōes Barreiras. A passagem para a planície costeira processa-se através de uma falésia mais ou menos demarcada. Campos de dunas, de provável idade pleistocênica, podem cobrir parcialmente os tabuleiros da Formação Barreiras. 


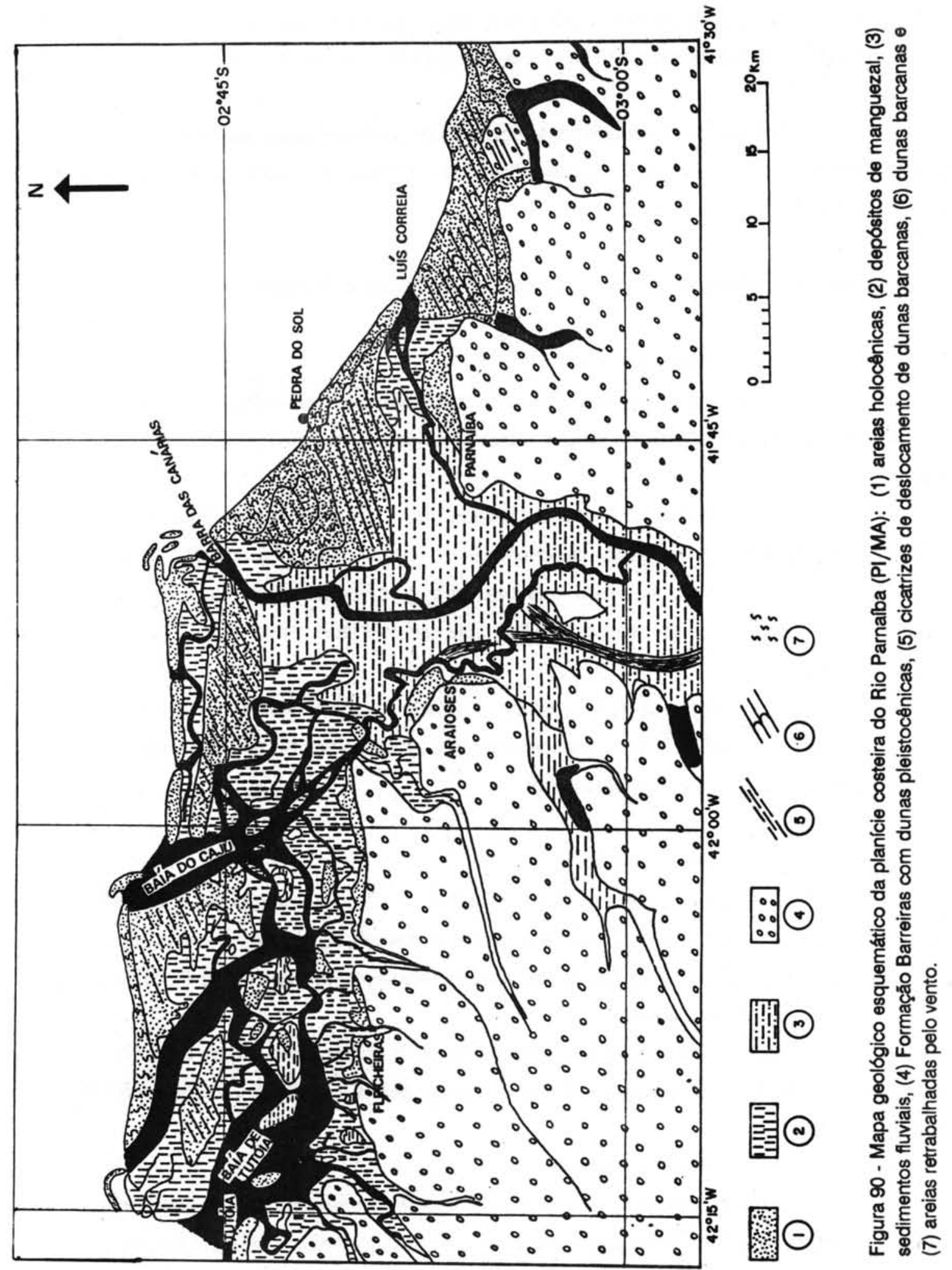


c) Planície Quaternária

Embutida nos sedimentos da Formação Barreiras e estendendo-se na direção E-W, ocorre a planície quaternária. O rio apresenta canal com padrão fortemente meandrante em virtude do balxo gradiente $\theta$ alta carga sedimentar. As feiçöes deposicionais da planície recebem forte influência өólica e, além disso, no interior da planície são encontrados extensos manguezais.

\subsubsection{Depósitos Quaternários (Fig. 90)}

a) Areias marinhas

Areias formando verdadeiros terraços marinhos são muito escassas nesta planicie, mas ocorrem na região de Araioses e entre as cidades de Parnaiba e Luís Correia. Certamente esses terraços testemunham niveis marinhos pretéritos mais altos do que o atual, porém ainda não se dispõe de dados suficientes para se estabelecer uma cronologia das variações de nivel relativo do mar na região.

b) Areias eólicas

Na porção externa da planície costeira, existem terraços arenosos recobertos por dunas ou apresentando na sua superfície alinhamentos deixados pela migração de dunas "tipo barcana". Esses alinhamentos têm orientação NE-SW, coincidindo com a direção dos ventos dominantes. Nos dois lados da desembocadura principal do Rio Parnafba, BACOCCOU (op.cit.) sugeriu a existência de cristas praiais em cúspide (Fig. 91), mas esta feição não ocorre e traços de migração de dunas devem ter sido confundidos com alinhamentos de cristas praiais. A parte interna desses terraços eólicos está recobrindo sedimentos fluviais ou manguezais e pode igualmente avançar sobre canais de maré. Freqüentemente, na superfície, não existem dunas mas somente cicatrizes deixadas durante a migração.

c) Depósitos fluviais

Em ambas as margens do Rio Parnaíba, na porção da planície entre os terraços eólicos e os sedimentos da Formação Barreiras, ocorrem zonas ocupadas por sedimentos fluviais.

d) Depósitos de manguezais

Toda a porção ocidental da planície costeira, entre os terraços eólicos e os sedimentos da Formação Barreiras, é ocupada por extensos manguezais.

\subsubsection{Evolução paleogeográfica}

a) Trabalho prévio

A planície costeira do Rio Parnaíba foi classificada por BACOCCOL (op.cit.) como "delta destrutivo dominado por ondas". Porém, esta classificação baseada no mapa por ele elaborado 


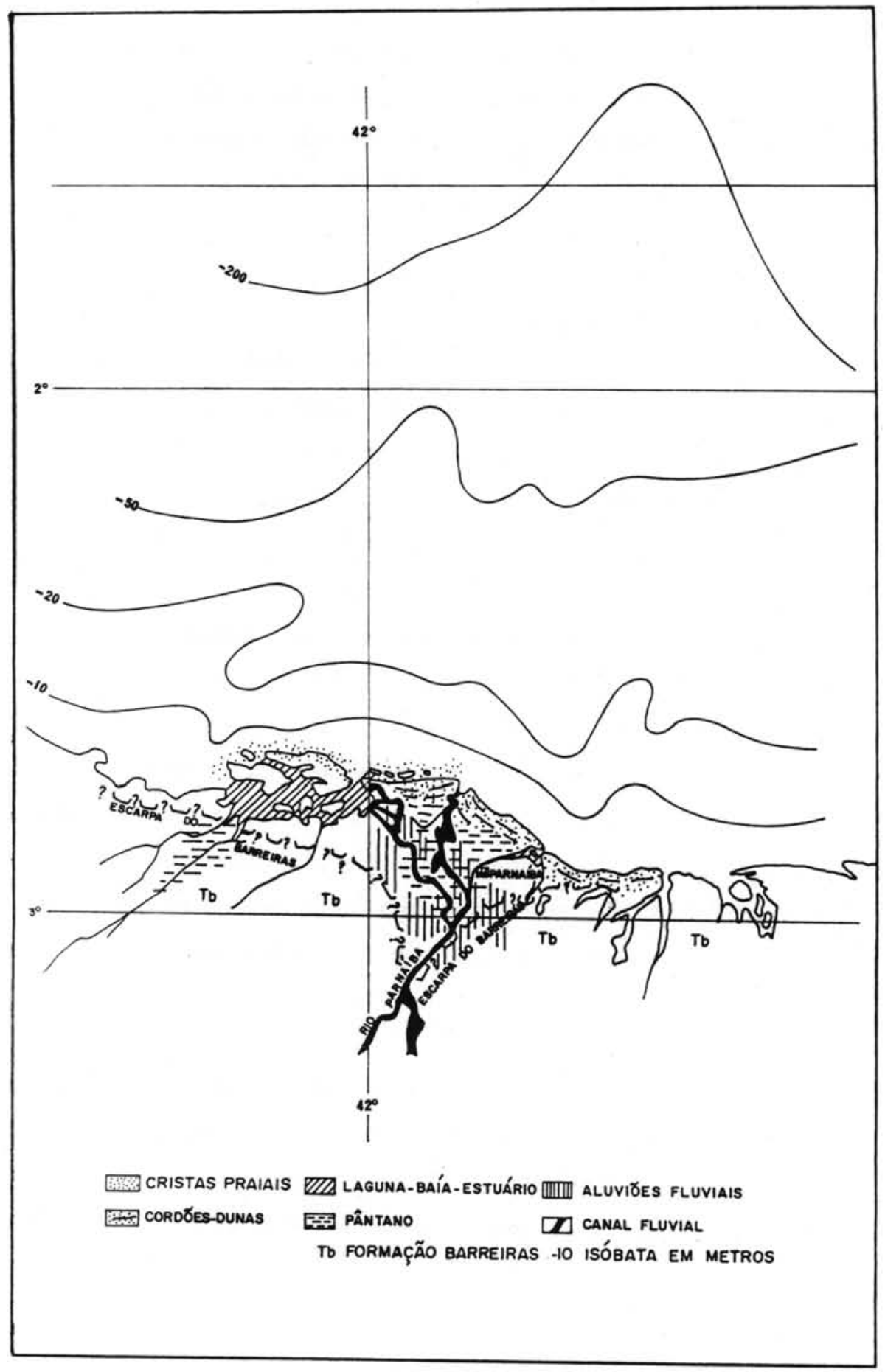

Figura 91 - Mapa geológico do "'delta" do Rio Parnaiba segundo BACOCCOU (1971). 
(Fig. 91) apresenta muitas imperfeições, que refletem na melhor compreensão desta planície. Algumas das imperfeições constatadas no mapa de BACOCCOU (op.cit.) são as seguintes:

- O limite interno da planície costeira não está correto.

- O curso inferior do Rio Parnalba não é constituido por dois braços iguais. 0 braço esquerdo (Rio Santa Rosa) é pouco importante e não exerce um papel significativo na sedimentação costeira.

- Não existem cristas praiais em cúspide em ambas as margens do Rio Parnaiba, junto a foz, como deveriam existir caso fosse um "clássico delta dominado por ondas".

b) Modelo proposto neste trabalho

A escassez de informação ainda não permite construir um modelo de evolução para esta planície costeira, como nos casos precedentes. Porém pode-se pensar que a região tenha passado por uma fase com ilhas-barreiras/laguna nas regiōes central e oriental, quando foi depositada parte da carga sedimentar do Rio Parnafba e desenvolveram-se manguezais na região ocidental. As areias marinhas, supridas provavelmente em conseqüência de abaixamento de nível relativo do mar e da deriva litorânea, teriam sido retrabalhadas pelos ventos e transportadas para o interior recobrindo os manguezais e os depósitos fluviais.

A desembocadura do rio parece ter ocupado várias posições. Deve ter havido uma época em que pelo menos um distributário importante desembocava na região de Luis Correia, e desde o deslocamento da foz a região a leste daquela cidade está sofrendo forte erosão em conseqüência do desaparecimento do bloqueio de transporte litorâneo de areias pelo fluxo fluvial. Do mesmo modo, durante algum tempo o rio parece ter desembocado na região da atual Baía de Caju.

\section{c) Considerações gerais}

Mesmo que não tenha sido possivel, por falta de dados sobre as variações de nivel relativo do mar e suas idades, estabelecer de maneira mais precisa a evolução costeira do Rio Parnafba, parece que ela passou por um estádio de ilhas-barreiras/laguna com construção de um delta intralagunar. Entretanto, diferentemente do que ocorreu nas planicies costeiras anteriormente estudadas, a progradação a partir das ilhas-barreiras é praticamente inexistente. De fato, as areias que poderiam alimentar esta progradação parecem ter sido transportadas para o interior pelo vento. Essas areias foram depositadas seja sobre sedimentos lagunares, seja sobre sedimentos fluviais. Nesta região, tendo estado sempre sob influência dos ventos alísios de NE, o transporte litorâneo sempre ocorreu de leste para oeste, de modo que as areias carreadas pelo Rio Parnaiba sempre foram depositadas a oeste das desembocaduras.

Deste modo, parece que a planície costeira do Rio Parnaíba não apresenta características de um "clássico delta dominado por ondas". 


\subsection{Planície costeira de Caravelas (forma deltaica sem rio)}

\subsubsection{Aspectos gerais}

A planície costeira de Caravelas está situada ao sul do Estado da Bahia, entre as desembocaduras dos rios Jequitinhonha e Doce. Ela ocupa uma superfície de cerca de $1.000 \mathrm{~km}^{2}$ e exibe uma forma mais ou menos triangular de $20 \times 100 \mathrm{~km}$ (Fig. 92). Esta planície está sujeita a marés de regime semidiurno, muito semelhantes às que afetam as planicies costeiras dos rios Doce $\theta$ Jequitinhonha. As ondas provém dos quadrantes ENE e SSE.

O clima da região é do tipo Af, segundo a classificação de Köppen, semelhante ao da planície costeira do Rio Jequitinhonha, caracteristicamente úmido e quente sem estação seca bem demarcada.

Nenhum rio de porte dos anteriormente descritos desemboca nas vizinhanças desta planicie. Somente cursos fluviais inexpressivos (rios Pardo e Alcobaça na porção norte e Peruíbe e Mucuri na porção sul) drenam a área, que é dividida em duas por um canal de maré bem desenvolvido. Talvez, a feição morfológica mais importante da área esteja situada na plataforma continental adjacente, representada por vastos bancos recifais mais ou menos ligados ao Arquipélago de Abrolhos, que criam uma zona de energia mais fraca favorável à formação desta planície costeira (Fig. 93).

\subsubsection{Geomorfologia}

Neste particular, a planície costeira de Caravelas apresenta as mesmas províncias das planícies anteriormente descritas, isto é, a) Região Serrana, b) Tabuleiros Terciários e c) Planície Quaternária.

a) Região Serrana

Cadeias montanhosas de rochas metamórficas e grantíticas, com até $1.000 \mathrm{~m}$ de altitude, de idade pré-cambriana, formam o substrato dos sedimentos cenozóicos da área.

b) Tabuleiros Terciários

Esta superfície está instalada sobre os sedimentos terciários continentais da Formação Barreiras. A sua altitude é mais ou menos constante ao norte de Alcobaça e se eleva lentamente para NW. Pequenos cursos de água que correm para o Oceano Atlântico entalharam sem dificuldades, vales prołundos nos locais onde o pacote sedimentar é mais espesso, superimpondo-se com certa dificuldade sobre os granitos subjacentes.

\section{c) Planície Quaternária}

Esta planície é caraterizada pela presença de terraços arenosos marinhos de idade quaternária, depósitos lagunares e inúmeros canais de maré margeados por manguezais. 


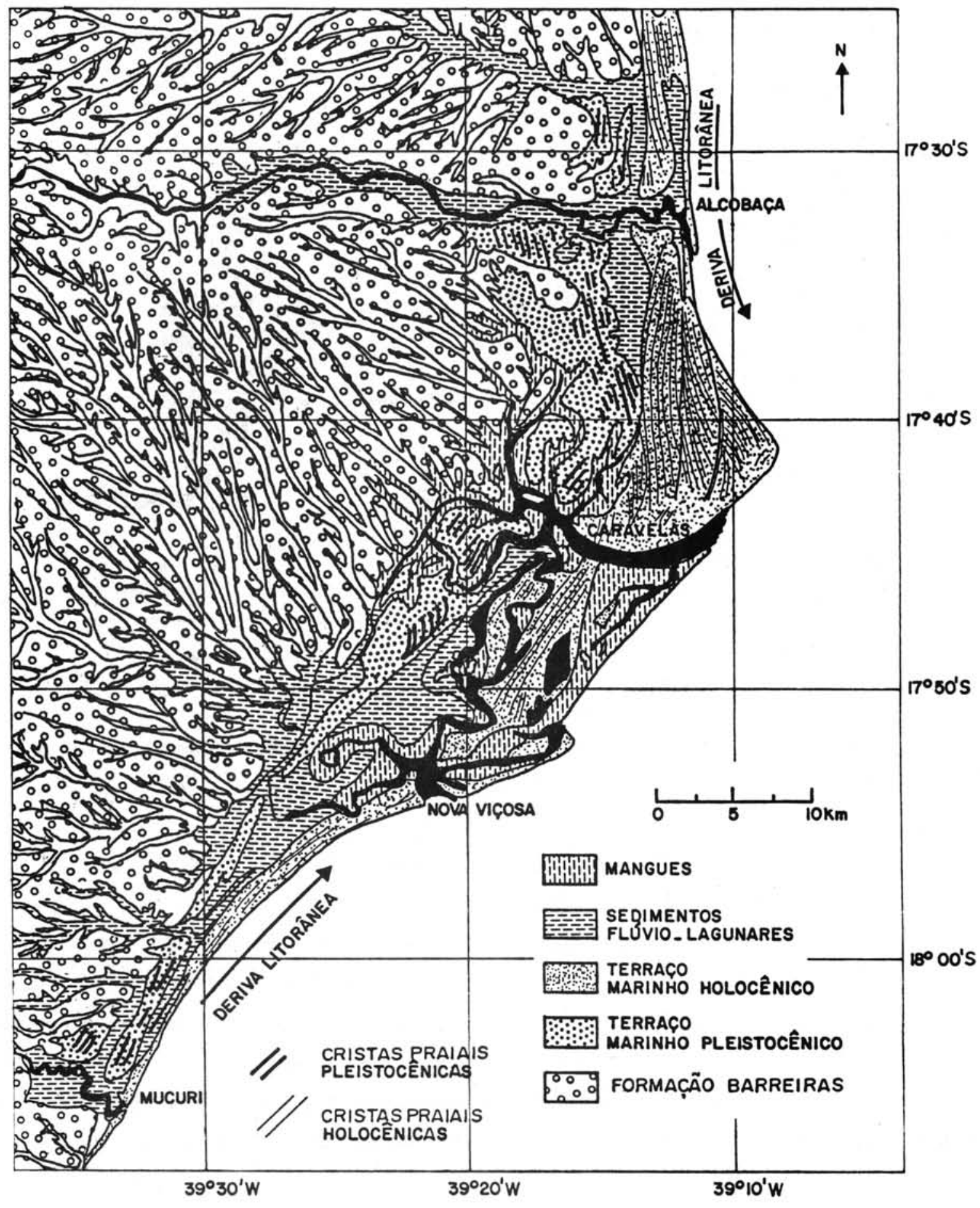

Figura 92 - Mapa geológico da planície costeira de Caravelas (BA). 


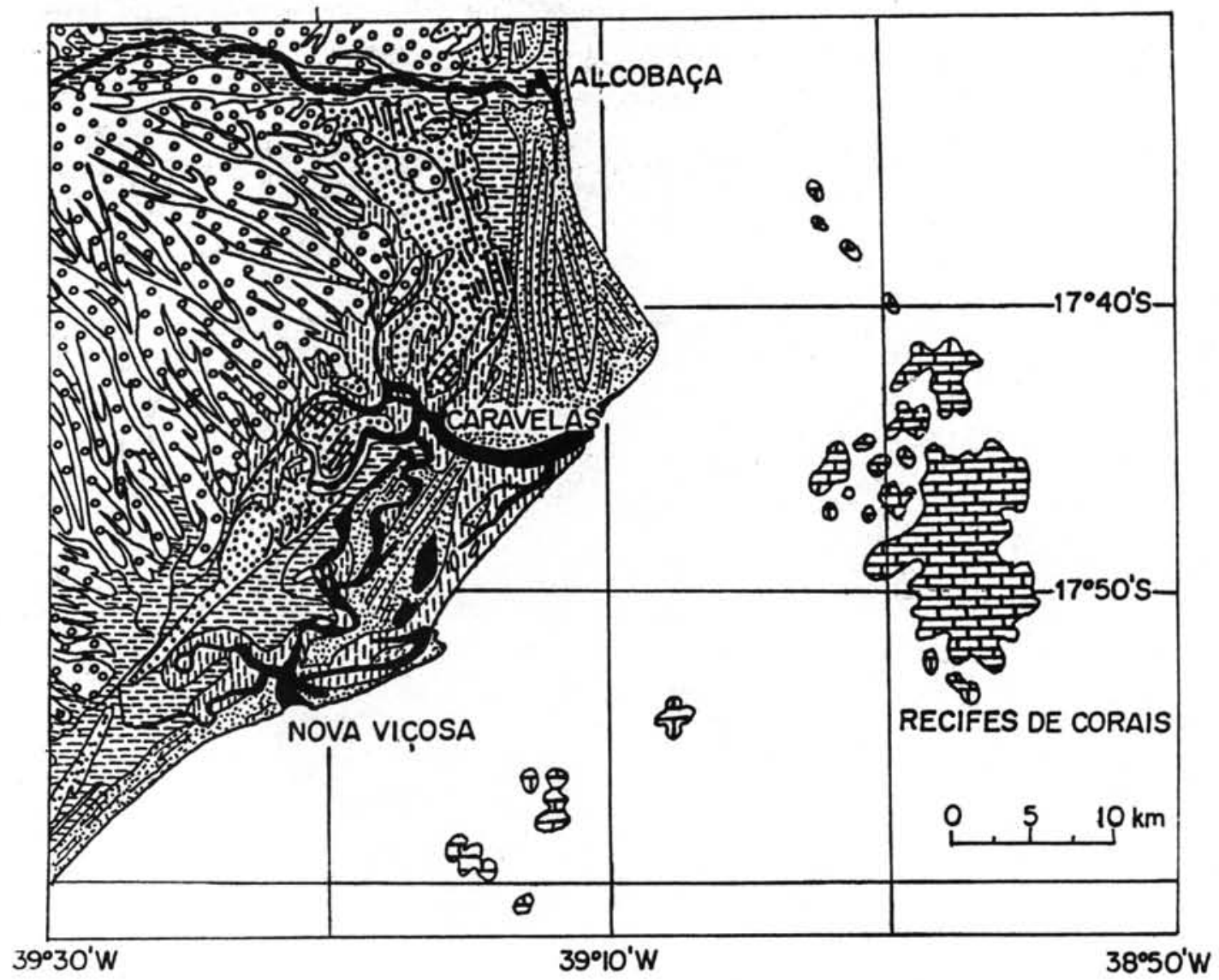

Figura 93 - Influência dos recifes de corais na construção da planície sedimentar de Caravelas pela criação de uma "área de sombra" de energia mais fraca.

\subsubsection{Depósitos Quaternários (Fig. 92)}

a) Areias marinhas pleistocênicas

Esses sedimentos, que vão de encontro às "falésias-mortas" esculpidas nos sedimentos da Formação Barreiras, formam uma faixa quase contínua entre Mucuri e Alcobaça. As mesmas características dos terraços marinhos pleistocênicos das planícies costeiras associadas a desembocaduras fluviais, com alinhamentos de cristas praiais mais espaçados e, mais ou menos obliterados, podem ser observados em fotografias aéreas. A direção dos alinhamentos dessas cristas sugere a influência dos bancos recifais adjacentes desde aquela época, isto é 123.000 anos A.P.

b) Areias marinhas holocênicas

Essas areias formam terraços encostados aos terraços pleistocênicos ou acham-se separados entre si por zonas deprimidas ocupadas por depósitos paleolagunares. Ao norte da Barra 
de Caravelas, formam um amplo sistema de cristas praiais exibindo duas discordâncias importantes que definem três zonas diferenciadas. Entre Mucuri e Nova Viçosa, o terraço marinho holocênico forma uma faixa estreita estando separado do terraço pleistocênico por uma zona paleolagunar. Entre Nova Viçosa e Barra de Caravelas, o terraço holocênico é separado do mar por um manguezal muito desenvolvido.

\section{c) Depósitos lagunares}

Nas regiōes de Alcobaça e Nova Viçosa, ocorrem duas zonas de paleolagunas, onde foram coletadas amostras de conchas de moluscos e fragmentos de madeira, que forneceram as seguintes idades:

$\begin{array}{lrc}\text { Número da amostra } & \begin{array}{c}\text { Idade radiocarbono } \\ \text { (anos A.P.) }\end{array} & \begin{array}{c}\text { Referência de laboratório } \\ \text { B-255 }\end{array} \\ \text { B-254 } & 7.010 \pm 120 & \text { Bah-768 } \\ \text { B-262 } & 6.650 \pm 120 & \text { Bah-767 } \\ \text { B-258 } & 5.760 \pm 160 & \text { Bah-772 } \\ \text { B-316 } & 5.700 \pm 120 & \text { Bah-769 } \\ \text { B-265 } & 3.670 \pm 120 & \text { Bah-800 } \\ \text { B-317 } & 3.640 \pm 100 & \text { Bah-775 } \\ & 3.310 \pm 100 & \text { Bah-801 }\end{array}$

As quatro primeiras datações estão de acordo com as idades obtidas para a primeira fase lagunar nas planícies costeiras dos rios Parafba do Sul, Doce e Jequitinhonha. As três últimas idades poderiam representar a segunda fase lagunar que foi evidenciada na planície costeira do Rio Doce.

d) Depósitos fluviais

Em virtude da inexistência de cursos fluviais mais expressivos, os depósitos fluviais são muito pouco desenvolvidos na área.

e) Depósitos de manguezais

Nos cursos inferiores dos rios Pardo, Alcobaça e Mucuri desenvolvem-se manguezais, mas os mais importantes situam-se ao longo dos canais de maré da porção central da planície costeira. 


\subsubsection{Evolução paleogeográfica}

Praticamente os mesmos oito estádios da história evolutiva das planícies costeiras dos rios Doce e Paraíba do Sul, com pequenas adaptações, podem ser admitidos para esta planície costeira.

$1^{\varrho}$ estádio - Corresponde à deposição dos sedimentos continentais terciários da Formação Barreiras.

$2^{2}$ e $3^{\circ}$ estádios - Evidências dessas fases, correspondentes respectivamente ao entalhamento de falésias na Formação Barreiras pela Antepenúltima Transgressão e deposição de leques aluviais coalescentes pós-Barreiras, não são conhecidas até o momento nesta planície costeira.

$4^{2}$ estádio - Corresponde ao máximo da Penúltima Transgressão, como em outras planícies costeiras, quando o nivel relativo do mar estava situado $8 \pm 2 \mathrm{~m}$ acima do atual há 123.000 anos A.P.

$5^{2}$ estádio - Durante a regressão subseqüente formou-se o terraço marinho pleistocênico. A geometria dos alinhamentos das cristas praiais sugere que os bancos recifais já estavam presentes na plataforma continental, tendo interferido no padrão de sedimentação costeira.

$6^{2}$ estádio - Nesta fase houve destruição parcial e afogamento dos terraços pleistocênicos. Em seguida, deve ter havido formação de sistemas de ilhas-barreiras/laguna nas porções norte e sul, enquanto os terraços holocênicos da porção central formaram-se diretamente apoiados aos pleistocênicos. A existência e a idade desta fase lagunar foram comprovadas, respectivamente, pelos sedimentos típicos e pela datação de conchas de moluscos.

$7^{0}$ estádio - Naturalmente, em conseqüência da inexistência de qualquer curso fluvial importante, não se formou o delta intralagunar.

$8^{\circ}$ estádio - Esta fase é representada pelas sucessivas seqüências de cristas praiais, formadas durante as fases de emersão entre 5.100 a 3.900, 3.600 a 2.900 e 2.500 anos A.P. até hoje.

A primeira fase é marcada pela construção da primeira geração de cristas praiais, cujos testemunhos mais importantes são encontrados entre Caravelas e Nova Viçosa. Amostras de conchas de moluscos de sedimentos paleolagunares subjacentes às cristas praiais foram datadas em $5.760 \pm 150$ (Bah-772) e 5.700 150 (Bah-769) anos A.P., enquanto que conchas de moluscos coletadas

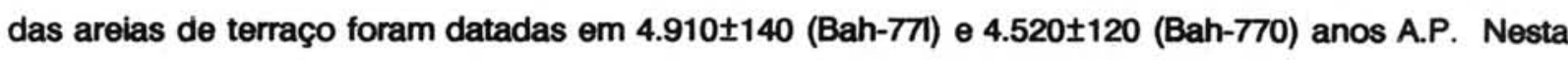
época, o canal de maré que desemboca em Caravelas não existia e a comunicação da laguna sul com o mar deveria se fazer na região de Nova Viçosa.

A segunda geração de cristas praiais acha-se bem representada entre Mucuri e Nova Viçosa. Conchas de moluscos de sedimentos paleolagunares subjacentes às cristas praiais foram datadas em $3.670 \pm 100$ (Bah-808) e 3.640 \pm 100 (Bah-775) anos A.P. Então, deve-se pensar que 
os terraços superpostos tenham sido formados após 3.600 anos A.P. Nesta época, o canal de maré de Caravelas já teria sido formado, pois entre Caravelas e Nova Viçosa não há testemunhos de terraço arenoso. Ao norte de Caravelas, a parte correspondente à segunda fase pode ser representada pela faixa de cristas praiais situadas entre as duas discordâncias, enquanto que. a leste da segunda discordância, os sedimentos devem ter sido depositados nos últimos 2.500 anos.

Ao sul da planície, as evidências geomorfológicas sugerem um transporte litorâneo do sul para o norte, enquanto que ao norte elas indicam um transporte do norte para o sul. Pode parecer estranho que não se encontre na planície sedimentar de Caravelas o tipo de erosão que ocorre na planície costeira do Rio Doce, situada um pouco ao sul. Porém, em Caravelas, a presença de vastos bancos de recifes de corais deve modificar toda a hidrodinâmica. De fato, a porção norte da planície é protegida das ondas do setor sul pelos recifes e a metade sul é abrigada das ondas do setor norte.

\section{c) Considerações gerais}

Estando ausente o elemento essencial de um delta, isto é, um curso fluvial supridor de sedimentos, é evidente que a planície costeira de Caravelas não pode ser considerada como um "delta dominado por ondas", mesmo que a morfologia da planície quaternária até sugira isso. Entretanto, como nas outras planícies por nós estudadas, a sua construção está suficientemente bem enquadrada no modelo de evolução litorânea idealizado para o trecho entre Macaé (RJ) e Maceió (AL).

\section{CONCLUSÕES FINAIS}

- $O$ espírito tem tanta dificuldade em acolher uma idéia nova quanto o corpo uma proteína estranha e a ela resiste com a mesma energia. Não seria exageradamente fantasioso afirmar que uma idéia nova é, para a ciência, o antígeno que atua com a maior rapidez. Uma visāo lúcida sobre nós mesmos permite freqūentemente descobrir que, já começamos a argumentar contra uma idéia, antes mesmo que ela tenha sido inteiramente formulada."

Wilfred Trotter

Uma das condições necessárias para que um depósito sedimentar situado em uma desembocadura fluvial seja denominado de delta é que ele tenha sido construído pelos sedimentos transportados por este rio, mesmo que estes tenham sido redistribuídos por agentes oceânicos, tais como as ondas e as marés.

A primeira vista, poderia parecer lógico classificar as planícies costeiras dos rios Paraíba do Sul, Doce, Jequitinhonha, São Francisco e Parnaíba na categoria de "deltas dominados por 
ondas" segundo a classificação de FISHER (op.cit.). Isto foi feito por BACOCCOU (op.cit.) para este conjunto de planícies costeiras, por ARAÚJO et al. (op.cit.) e DIAS et. al. (op.cit.) para o Rio Paraiba do Sul, por BANDEIRA et. al. (op.cit.) para o Rio Doce e por COLEMAN \& WRIGHT (op.cit.) para o Rio São Francisco. Entretanto, um exame do trabalho realizado por BACOCCOU mostra que os mapas apresentados por este autor são baseados principalmente em dados de gabinete. Estes mapas não representam a realidade, fato que pode ser verificado por uma simples inspeção de fotografias aéreas das regióes estudadas. O mesmo ocorre com o mapa de COLEMAN \& WRIGHT (op.cit.) sobre a foz do Rio São Francisco, onde a falxa de manguezal existente, com $5 \times 25 \mathrm{~km}$ de área, năo fol representada ao sul da desembocadura pois, no modelo adotado, um manguezal não poderia aparecer naquela situação.

Uma das condições essenciais para que um modelo, válido para uma regiăo, seja aplicável em outra, é que as condições dinâmicas sejam semelhantes em ambas as regiōes. Dentro deste prisma, foi possível mostrar que, por exemplo, as variações de nivel relativo do mar ao longo da costa brasileira, um dos elementos essenciais da dinâmica litorânea no decorrer do Holoceno, seguiram padrões bem diferentes nas costas dos Estados Unidos da América do Norte e da Europa.

Os estudos realizados nas planícies costeiras dos rios Paraíba do Sul, Jequitinhonha, Doce, São Francisco e Parnalba, baseados em cartografia de detalhe e em numerosas datações por radiocarbono permitiram construir mapas geológicos não interpretativos. Foi possivel também, baseando-se em dados efetivamente medidos, reconstruir a história de evolução destas planícies durante o Quaternário. Foi então mostrado que, contrariamente às aparências, aqueles rios não constitulam a principal fonte das areias que formam grande parte das planicies costeiras situadas nas desembocaduras. Verificou-se com efeito que, a maior parte dessas areias, provinha da plataforma continental interna em conseqüência do abaixamento de nivel relativo do mar, que ocorreu após 5.100 anos A.P. Por outro lado, mostrou-se também que os rios desempenharam um papel essencial na construção dessas planícies, através do bloqueio do transporte litorâneo das areias fornecidas pelo abaixamento de nível médio relativo do mar, provocando uma grande acumulação de areias a barlamar, isto é, a montante da corrente de deriva litorânea. Esta questão foi analisada através dos graus de arredondamento dos grãos de areia em ambas margens da desembocadura do Rio Paraíba do Sul. Ficou então claro que estas planícies costeiras não podem, a rigor, ser classificadas na categoria de "deltas dominadas por ondas" e, além do mais, verificou-se a existência, ao longo do litoral brasileiro, de planícies costeiras como, por exemplo, a de Caravelas (BA) apresentando as mesmas características, mas sem nenhum vínculo direto ou indireto com desembocaduras fluviais.

Apesar de todas as evidências apresentadas, este modelo foi, às vezes, contestado por alguns pesquisadores. Deve-se acrescentar a isto que o mapa da foz do Rio São Francisco de 
COLEMAN \& WRIGHT (op.cit.), com todas as imprecisões, tem sido utilizado em várias publicações norte-americanas como modelo de "deltas dominados por ondas".

A História da Ciência fornece inúmeros e interessantes exemplos sobre as dificuldades que as idélas novas têm para ser implantadas. Assim, a teoria da deriva dos continentes de WEGENER fol ferrenhamente combatida pela maior parte da comunidade geológica e geofisica, até que bruscamente ocorreu um reviravolta na opinião. Atualmente, é dificil entender como as maiores sumidades das ciências geológicas puderam refutar os dados precisos e evidentes apresentados por WEGENER. Apesar de haver enganos sobre os mecanismos que provocam a deriva, os argumentos geológicos, morfológicos e paleontológicos apresentados parecem, hoje, inquestionáveis.

\footnotetext{
"Uma conseqüéncia curiosa da inércia merece figurar no elenco das leis fundamentais da natureza pois, quando uma teoria é finalmente aceita pela unanimidade, percebe-se que ela já havia sido, muito tempo antes, formulada em detalhe e estava respaldada em argumentos de grande solidez".
}

F.C.S.Schiller

\section{REFERÊNCIAS BIBLIOGRÁFICAS}

ALLEN, J.R.L (1965) Late Quaternary Niger delta and adjacent areas: sedimentary environments and lithofacies. A.A.P.G. Bulletin, 23:547-600.

ALMEIDA, F.F.M. (1969) Diferenciação tectônica da Plataforma Brasileira. In: CONGRESSO BRASILEIRO DE GEOLOGIA, 23., Salvador, 1969. Anais. Salvador, SBG. p.29-46.

ALMEIDA, F.F.M. (1971) Geochronological division of the Precambrian of South America. Revista Brasileira de Geociências, 1(1):13-21.

ALMEIDA, F.F.M. (1976) The Upper Precambrian of South America. Boletim IG-USP, 7:45-80.

ANDRADE, G.O. (1964) Os climas. In: AZEVEDO, A. (ed.) Brasil: a terra e o homem. São Paulo, Nacional. p.397-457.

ARAÚJO, M.B.; BEURLEN, G.; PIAZZA, H.D.; CUNHA, M.C.C.; SANTOS, A.S. (1975) In: Projeto Rio

Paraíba do Sul: Sedimentação deltaica holocênica. Rio de Janeiro, Petrobrás/RPBA, Dextro/Divex. 2V. (Relatório Direx 1649).

ASMUS, H.E. (1979) Conocimiento actual del margin continental brasileño. In: CONGRESO LATINO 
AMERICANO dE GeOlogíA, 4., Puerto España, 1979. Anales. Puerto España.

ASMUS, H.E. \& PONTE, F.C. (1973) The Brazilian marginal basins. In: NAIRN, A.E.M. \& STEHU, F.G. (eds.) The ocean basins and margins. New York, Plenum, v.1, p.87-133.

BACOCCOL, G. (1971) Os deltas marinhos holocênicos brasileiros: uma tentativa de classificação.

Boletim Técnico da Petrobrás, 14(1-2):5-38.

BANDEIRA JúNIOR, A.N.; PETRI, S.; SUGUIO, K. (1975) Projeto Rio Doce. Rio de Janeiro, Petrobrás/Cenpes. 203p. (Relatório Final).

BARBOSA, LM.; BITTENCOURT, A.C.S.P.; DOMINGUEZ, J.M.L; MARTIN, L (1986a) Geologia do

Quaternário Costeiro do Estado de Alagoas. In: DANTAS, J.R.A. (ed.) Mapa Geológico do

Estado de Alagoas. Brasflia, DEM/DNPM. Escala 1:250.000.

BARBOSA, L.M.; BITTENCOURT, A.C.S.P.; DOMINGUEZ, J.M.L; MARTIN, L (1986b) The Quaternary coastal deposits of the State of Alagoas: influence of relative sea level changes. In: RABASSA, J. (ed.) Quaternary of South America and Antarctic Peninsula. Rotterdam, A.A. Balkema Publishers. v.4, p.269-290.

BARREL, J. (1912) Criteria for the recognition of ancient delta deposits. Bulletin of the Geological Society of America, 23:377-446.

BATES, C.C. (1953) Rational theory of delta formation. A.A.P.G. Bulletin, 37(9):2119-2162.

BEURLEN, K. (1967) Estratigrafia da faixa sedimentar costeira Recife-Joáo Pessoa. Boletim da Sociedade Brasileira de Geologia, 16(1):2119-2162.

BIGARELLA, J.J. (1965) Subsídios para o estudo das variações do nivel oceânico no Quaternário Brasileiro. Anais da Academia Brasileira de Ciências, (Suplemento) 37:263-278.

BIGARELLA, J.J. (1975a) The Barreiras Group in northeastern Brazil. Anais da Academia Brasileira de Ciências, (Suplemento) 47:365-393.

BIGARELLA, J.J. (1975b) Reef sandstone from northeastern Brazil. Anais da Academia Brasileira de Ciências, (Suplemento) 47:395-409.

BIGARELA, J.J. \& ANDRADE, G.O. (1964) Considerações sobre a estratigrafia dos sedimentos cenozóicos em Pernambuco (Grupo Barreiras). Arquivos do Instituto das Ciências da Terra, 2:2-14.

BITTENCOURT, A.C.S.P.; MARTIN, L; VILAS-BOAS, G.S.; FLEXOR, J.M. (1979a) Quaternary marine formations of the coast of the State of Bahia, Brazil. In: INTERNATIONAL SYMPOSIUM ON COASTAL EVOLUTION IN THE QUATERNARY. São Paulo, 1978. Proceedings. São Paulo, Instituto de Geociências/SBG. p.232-253.

BITTENCOURT, A.C.S.P.; VILAS-BOAS, G.S.; FLEXOR, J.M.; MARTIN, L (1979b) Geologia dos depósitos quanternários do litoral do Estado da Bahia. In: INDA, H. (ed.) Geologia e recursos 
minerais do Estado da Bahia: textos básicos. Salvador, Secretaria de Minas e Energia/CPM. v.1, p.2-21.

BITTENCOURT, A.C.S.P.; DOMINGUEZ, J.M.L; MARTIN, L; FERREIRA, Y.A. (1982a) Dados preliminares sobre a evolução do "delta" do Rio São Francisco (SE/AL) durante o Quaternário: influência das variações do nivel do mar. In: SIMPÓSIO DO QUATERNÁRIO NO BRASIL, 4., Rio de Janeiro, 1981. Atas. Rio de Janeiro, CTCQ/SBG. p.49-68.

BITTENCOURT, A.C.S.P.; MARTIN, L; DOMINGUEZ, J.M.L; FERREIRA, Y.A. (1982b) O Quaternário Costeiro do Estado de Sergipe. In: CONGRESSO BRASILEIRO DE GEOLOGIA, 32., Salvador, 1982. Resumos e Breves Comunicações. Boletim n² 2. Salvador, SBG. p.92.

BITTENCOURT, A.C.S.P.; MARTIN, L; DOMINGUEZ, J.M.L; FERREIRA, Y.A. (1983a) Evolução paleogeográfica quaternária da costa do Estado de Sergipe e sul da costa do Estado de Alagoas. Revista Brasileira de Geociências, 13(2):93-97.

BITTENCOURT, A.C.S.P.; MARTIN, L; DOMINGUEZ, J.M.L; FERREIRA, Y.A. (1983b) Mapa do Quaternário Costeiro. In: Mapa Geológico do Estado de Sergipe. Braslla, DNPM. Escala $1: 250.000$.

BRANNER, J.C. (1904) The stone reefs of Brazil, their geological and geographical relations. Bulletin of the Museum of Comparative Zoology. Geological Series, 44(7).

BRAZ FILHO, P.A. (1980) Prospecto turfa (Baixo Rio São Francisco). Salvador, CPRM/SUREG. 27p. (Relatório C.C. 2606/010).

BRITO NEVES, B.B. \& CORDANI, U.G. (1991) Tectonic evolution of South America during the Late Proterozoic. Precambrian Research, 53(1/2):23-40.

BRUUN, P. (1962) Sea level rise as a cause of shore erosion. Journal of the Waterways and Harbors Division. American Society of Civil Engineers, 88:117-130.

CAILIEUX, A. \& TRICART, J. (1959) Initiation à l'étude des sables et galets. Paris: Centre de Documentation Universitaire, 376p.

CEPLAB (1979) Bacias hidrográficas do Estado da Bahia. Salvador, Centro de Planejamento da Bahia. Serie Recursos Naturais. v.1, 109p.

COLEMAN, J.M. \& WRIGHT, L.D. (1971) Analysis of major river systems and their deltas, procedure and rationale, with two examples. Louisiana State University, Coastal Studies Institute. Technical Report, (95):1-125.

COLEMAN, J.M. \& WRIGHT, L.D. (1972) Delta morphology in relation to the discharge/wave power climate. In: CONGRESSO BRASILEIRO DE GEOLOGIA, 26., Belém, 1972. Anais. Belém, SBG. v.2, p.145-155.

COLEMAN, J.M. \& WRIGHT, LD. (1975) Modern river deltas: variability of process and sand bodies. 
In: BROUSSARD, M.L (ed.) Deltas - models for exploration. Houston, United States, Houston Geological Society. p.99-149.

COUTINHO, P.N. (1970) Sedimentation at the mouth of the São Francisco river (Brazil). Trabalhos Oceanográficos, Universidade Federal de Pernambuco, 9/11:41-50.

DAVIES, J.E. (1972) Geographical variation in coastal development. In: CLAYTON, K.M. (ed.) Geomorphology Text 4. New York, Longman Group Ltd. p.204.

DIAS, G.T.M. (1981) O complexo deltaico do Rio Paralba do Sul. In: SIMPÓSIO DO QUATERNÁRIO NO BRASIL, 4., Rio de Janeiro, 1981. Roteiro de excursão geológica. Publicação Especial, n² 2 , Rio de Janeiro, CTCQ/SBG. p.38-64.

DIAS, G.T.M. \& GORINI, M.A. (1979) Morfologia e dinâmica da evolução do delta atual do Rlo Parafba do Sul. In: SEMANA DE GEOLOGIA, 5., Rio de Janeiro, 1980. Anais. Rio de Janeiro, UFRJ, p.5563.

DIAS, G.T.M. \& GORINI, M.A. (1980) A baixada campista - estudo morfológico dos ambientes litorâneos. In: CONGRESSO BRASILEIRO DE GEOLOGIA, 31., Camboriú, 1980. Anais. Camboriú, SBG. v.1, p.588-602.

DIAS, G.T.M.; SILVA, C.G.; MALSCHITZCKY, I.H.; PIRMEZ, C. (1984a) A frente deltaica do Rio Paraíba do Sul: fisiografia submarina e distribuição sedimentar. In: CONGRESSO BRASILEIRO DE GEOLOGIA, 33., Rio de Janeiro, 1984. Anais. Rio de Janeiro, SBG. v.4, p.1565-1576.

DIAS , G.T.M.; SILVA, C.G.; MALSCHITZCKY, I.H.; PIRMEZ, C. (1984b) A planície deltaica do Rio Paraíba do Sul: seqüências sedimentares subsuperficiais. In: CONGRESSO BRASILEIRO DE GEOLOGIA, 33., Rio de Janeiro, 1984. Anais. Rio de Janeiro, SBG. v.1, p.98-104.

DIAS-BRITO, D. \& ZANINETTI, L. (1979) Étude géobotanique comparative de trois mangroves du littoral brésilien: Acupe (BA), Guaratiba (RJ) et Iguape (SP). Notes Laboratoire de Paleontologie, 4(1/6):57-65.

DOMINGUEZ, J.M.L. (1982) Evolução quaternária da planície costeira associada à foz do Rio Jequitinhonha (BA): influência das variaçōes do nível do mar e da deriva litorânea de sedimentos. Salvador, 73p. (Dissertação de Mestrado - Universidade Federal da Bahia).

DOMINGUEZ, J.M.L. (1987) Quaternary sealevel changes and the depositional architecture of beach-ridge strandplains along the east coast of Brazil. Miami, 288p. (Doctoral Dissertation University of Miami).

DOMINGUEZ, J.M.L (1989) Ontogeny of a strandplain: evolving concepts on the evolution of the Doce river beach-ridge plain (east coast of Brazil). In: INTERNATIONAL SYMPOSIUM ON GLOBAL CHANGES IN SOUTH AMERICA DURING THE QUATERNARY, São Paulo, 1989. Special Publication, 1. São Paulo, ABEQUA/INQUA, p.235-240. 
DOMINGUEZ, J.M.L; BITTENCOURT, A.C.S.P.; MARTIN, L. (1981a) Esquema evolutivo da sedimentação quaternária nas feições deltaicas dos rios São Francisco (SE/AL), Jequitinhonha (BA), Doce (ES) e Paraf́ba do Sul (RJ). Revista Brasileira de Geociências, 11(4):227-237.

DOMINGUEZ, J.M.L; MARTIN, L; BITTENCOURT, A.C.S.P. (1981b) Evolução paleogeográfica do delta do Rio Jequitinhonha durante o Quaternário: influência das variações do nivel do mar. In: SIMPÓSIO DO QUATERNÁRIO NO BRASIL, 4., Rio de Janeiro, 1981. Atas. Rio de Janeiro, CTCQ/SBG. p.69-83.

DOMINGUEZ, J.M.L;; BITTENCOURT, A.C.S.P.; MARTIN, L (1983) O papel da deriva litorânea de sedimentos arenosos na construção das planícies costeiras associadas a desembocaduras dos rios São Francisco (SE/AL), Jequitinhonha (BA), Doce (ES) e Parafba do Sul (RJ). Revista Brasileira de Geociências, 13(2):93-105.

DUBOIS, R.N. (1976) Nearshore evidence in support of the Bruun rule on shore erosion. Journal of Geology, 84(4):485-491.

DUBOIS, R.N. (1977) Predicting beach-erosion as a function of rising water level. Journal of Geology, 85(4):470-476.

FERNANDES FILHO, J.A.; MURICY FILHO, A.F.; SILVA, O.B.; ZABALAGA, H.M.C. (1982) Estágio atual da exploração de petróleo na Bacia do Recôncavo. In: CONGRESSO BRASILEIRO DE GEOLOGIA, 32., Salvador, 1982. Anais, Salvador. v.5, p.2273-2285.

FERREIRA, Y.A. (1969) Recifes de arenito de Salvador, Bahia. Anais da Academia Brasileira de Ciências, 41(4):541-548.

FISHER, W.L. (1969) Facies characterization of Gulf coast basin delta system, with Holocene analogous. Transactions Gulf Coast Association of Geological Societies, 19:239-261.

FLEXOR, J.M. \& MARTIN, L (1979) Sur l'utilisation des grès coquilliers de la région de Salvador (Brésil) dans la reconstruction des lignes de rivage holocènes. In: INTERNATIONAL SYMPOSIUM ON COASTAL EVOLUTION IN THE QUATERnARY. São Paulo, 1978. Proceedings. São Paulo, Instituto de Geociências/SBG. p.343-355.

FLEXOR, J.M.; MARTIN, L; SUGUIO, K. (1979) Utilisation du rapport isotopique ${ }^{13} \mathrm{C} /{ }^{12} \mathrm{C}$ comme indicateur d'oscillations lagunaires. In: INTERNATIONAL SYMPOSIUM ON COASTAL EVOLUTION IN THE QUATERNARY. São Paulo, 1978. Proceedings. São Paulo, Instituto de Geociências/SBG. p.358-375.

FREITAS, R.O. (1951) Ensaio sobre a tectônica moderna do Brasil. Boletim da Faculdade de Filosofia, Ciências e Letras da Universidade de São Paulo, (130):1-120. (Geologia 6).

GALOWAY, W.E. (1975) Process framework for describing the morphologic and stratigraphic evolution of deltaic depositional systems. In: BROUSSARD, M.L (ed.) Deltas - models for 
exploration. Houston, United States, Houston Geological Society. p.87-89.

GALVÃO, M.V. \& NIMER, E. (1965) Geografia do Brasil - Grande região leste (clima). Rio de Janeiro, IBGE. p.91-139.

GAMA JÚNIOR, E.G. (1970) Modelo geológico das bacias do Recôncavo e Tucano. In: CONGRESSO BRASILEIRO DE GEOLOGIA, 24., Brasnia, 1970. Anais. Brasila, SBG. p.191-200.

GHIGNONE, J.I. (1979) Geologia dos sedimentos fanerozólcos do Estado da Bahia. In: INDA, H. (ed.) Geologia e recursos minerais do Estado da Bahia: textos básicos. Salvador, Secretaria de Minas e Energia/CPM. v.1, p.24-117.

GILBERT, G.K. (1889) Lake Bonneville. U.S.Geological Survey Memoir, (1):1-438.

GOUVEIA, J.P.S.. (1970) Contribuição à geomorfologia do sul da Bahia: área dos baixos cursos dos rios Pardo e Jequitinhonha. Notícias Geomorfológicas, 10:13-20.

HARTT, C.F. (1870) Geology and physical geography of Brazil. Boston, Fields, 620p.

KING, C.A.M. (1972) Beaches and coasts. 2.ed. London, Edward Arnold. 570p.

KOMAR, P.D. (1973) Computer models of delta growth due to sediment input from rivers and longshore transport. Bulletin of the Geological Society of America, 84(7):2217-2226.

KÖPPEN, W. (1948) Climatología: con un estudio de los climas de la Tierra. México, Fondo de Cultura Económica.

LABOREL, J. (1969) Les peuplements de Madreporaires des côtes tropicales du Brésil. Annales de I'Universite d'Abidjan. Serie E, 2(3):1-260.

LABOREL, J. (1979) Fixed marine organisms as biological indicators for the study of recent sea level and climatic variations along the Brazilian tropical coast. In: INTERNATIONAL SYMPOSIUM ON COASTAL EVOlUtion IN THE QUATERnARY. São Paulo, 1978. Proceedings. São Paulo, Instituto de Geociências/SBG. p.193-211.

LAMEGO, A.R. (1955) Geologia das quadrículas de Campos, São Tomé, Lagoa Feia e Xexé. Boletim. Divisão de Geologia e Mineralogia/DNPM, (154):1-60.

LARRAS, J. (1961) Cours d'hydraulique maritime et de travaux maritimes. Paris, DUNOD. 459p.

LEÃO, Z.M.A.N. (1982) Morphology, geology and developmental history of the southernmost coral reefs of Western Atlantic. Abrolhos Bank, Brazil. Miami, 218p. (Ph.D. Dissertation - University of Miami).

LE BLANC, R.J. (1975) Review of studies of deltaic sedimentation. In: BROUSSARD, M.L (ed.) Deltas models for exploration. Houston Geological Society, p:13-85.

LYELL, C. (1832) Principles of Geology. Londres, John Murray. 511p.

MABESOONE, J.M. (1964) Origin and age of the sandstone reefs of Pernambuco (Northeastern Brazil). Journal of Sedimentary Petrology, 34(4):1-7. 
MABESOONE, J.M.; CAMPOS E SILVA, A.; BEURLEN, K. (1972) Estratigrafia e origem do Grupo Barreiras em Pernambuco, Parafba e Rio Grande do Norte. Revista Brasileira de Geociências, 2(3):173-188.

MARTIN, L. \& DOMINGUEZ, J.M.L (prelo) Geological history of coastal lagoons with particular reference to examples from the east coast of Brazil. In: KJERVE, B. (ed.) Coastal lagoon process.

MARTIN, L. \& SUGUIO, K. (1975) The State of São Paulo coastal marine quaternary geology. The ancient strandlines. Anais da Academia Brasileira de Ciências, (Suplemento) 47:249-263.

MARTIN, L \& SUGUIO, K. (1976a) Étude préliminaire du Quaternaire marin. Comparaison du littoral de São Paulo et Salvador, Brésil. Cahiers ORSTOM, Série Géologie, 8(1):33-47.

MARTIN, L. \& SUGUIO, K. (1976b) Les variations du niveau de la mer au Quaternaire Récent dans le sud de l'état de São Paulo. Utilisation des "sambaquis" dans la détermination d'anciennes lignes de rivage holocènes. In: CONGRES INTERNATIONAL DES AMÉRICANISTES, 42., Paris, 1976. Actes. Paris, Fondation Singer-Polignac. V.9A, p.73-83.

MARTIN, L \& SUGUIO, K. (1976c) O Quaternário Marinho do Estado de São Paulo. In: CONGRESSO BRASILEIRO DE GEOLOGIA, 29., Ouro Preto, 1976. Anais. Ouro Preto, SBG. v.1, p.281-294.

MARTIN, L. \& SUGUIO, K. (1978a) Ilha Comprida: um exemplo de ilha-barreira ligada às flutuações do nível marinho durante o Quaternário. In: CONGRESSO BRASILEIRO DE GEOLOGIA, 30., Recife, 1978. Anais. Recife, SBG. v.2, p.905-912.

MARTIN, L \& SUGUIO, K. (1978b) Excursion route along the coastline between the town of Cananeia (State of São Paulo) and Guaratiba outlet (State of Rio de Janeiro). In: INTERNATIONAL SYMPOSIUM ON COASTAL EVOLUTION IN THE QUATERNARY. São Paulo, 1978. Special Publication, 2. São Paulo, Instituto de Geociências/SBG. p.1-97.

MARTIN, L \& SUGUIO, K. (1986) Excursion route along the coastal plains of the states of Parana and Santa Catarina. In: INTERNATIONAL SYMPOSIUM ON SEA LEVEL CHANGES AND QUATERNARY SHORELNES. São Paulo, 1986. Special Publication, 1. São Paulo, ABEQUA/INQUA. p.124.

MARTIN, L; BITTENCOURT, A.C.S.P.; VILAS-BOAS, G.S.; FLEXOR, J.M. (1978) Introdução ao estudo do Quaternário do litoral da Bahia: trecho Salvador-llhéus. Revista Brasileira de Geociências, 9(4):309-320.

MARTIN, L; FLEXOR, J.M.; VILAS-BOAS, G.S.; BITTENCOURT, A.C.S.P.; GUIMARÃES, M.M.M. (1979a) Courbe de variation du niveau relatif de la mer au cours des 7000 dernières années sur un secteur homogène du littoral brésilien (nord de Salvador). In: INTERNATIONAL SYMPOSIUM ON COASTAL EVOLUTION IN THE QUATERNARY, São Paulo, 1978. Proceedings. São Paulo, 
Instituto de Geociências/SBG. p.264-274.

MARTIN, L.; SUGUIO, K.; FLEXOR, J.M. (1979b) Le Quaternaire marin du littoral brésilien entre Cananéia (SP) et Barra de Guaratiba (RJ). In: INTERNATIONAL SYMPOSIUM ON COASTAL EVOLUTION IN THE QUATERNARY, São Paulo, 1978. Proceedings. São Paulo, Instituto de Geociências, SBG. p.296-331.

MARTIN, L.; BITTENCOURT, A.C.S.P.; VILAS-BOAS, G.S.; FLEXOR, J.M. (1980a) Mapa geologico do quaternário costeiro do Estado da Bahia. Salvador, Secretaria de Minas e Energia/CPM. Escala 1:250.000.

MARTIN, L.; SUGUIO, K.; FLEXOR, J.M.; BITTENCOURT, A.C.S.P.; VILAS-BOAS, G.S. (1980b) Le Quaternaire marin brésilien (littoral pauliste, sud-fluminense et bahianais). Cahiers ORSTOM, Série Géologie, 9(1): 96-124.

MARTIN, L; VILAS-BOAS, G.S.; BITTENCOURT, A.C.S.P.; FLEXOR, J.M. (1980c) Origine des sables et âges des dunes situées au nord de Salvador (Brésil). Importance paléoclimatique. Cahiers ORSTOM, Série Géologie, 11(1):125-132.

MARTIN, L.; BITTENCOURT, A.C.S.P.; FLEXOR, J.M.; SUGUIO, K.; VILAS-BOAS, G.S. (1981a) Modification de la morphologie du littoral des états de Bahia et Såo Pauo (Brésil) en fonction des variations du niveau rélatif de la mer. Océanis, 7(4):409-414.

MARTIN, L.; BITTENCOURT, A.C.S.P.; VILAS-BOAS, G.S. (1981b) Différentiation sur photographies aériennes des terrasses sableuses pléistocènes et holocènes du littoral de l'état de Bahia (Brésil). Photo-Interprétation, 20(3):4.5.1-4.5.10.

MARTIN, L; BITTENCOURT, A.C.S.P.; VILAS-BOAS, G.S. (1982) Primeira ocorrência de corais pleistocênicos da costa brasileira - Datação do máximo da penúltima transgressão. Ciências da Terra, 1:16-17.

MARTIN, L;; DOMINGUEZ, J.M.L.; SUGUIO, K.; BITTENCOURT, A.C.S.P.; FLEXOR, J.M. (1983) Schéma de la sédimentation quaternaire sur la partie centrale du littoral brésilien. Cahiers ORSTOM, Série Géologie, 13(1):59-81.

MARTIN, L.; BITTENCOURT, A.C.S.P.; FLEXOR, J.M.; VILAS-BOAS, G.S. (1984a) Evidência de um tectonismo quaternário nas costas do Estado da Bahia. In: CONGRESSO BRASILEIRO DE GEOLOGIA, 33., Rio de Janeiro, 1984. Anais. Rio de Janeiro, SBG. v.1, p.19-35.

MARTIN, L.; FLEXOR, J.M.; KOUSKY, V.; CAVALCANTI, I.F.A. (1984b) Inversion du sens du transport littoral enregistrées dans les cordons littoraux de la plaine côtière du Rio Doce (Brésil). Possible liaison avec des modifications de la circulation atmosphérique. Comptes Rendus Hebdomadaires des Seances de L'Academie des Sciences. Ser.II, 298(1):25-27.

MARTIN, L.; FLEXOR, J.M.; SUGUIO, K. (1984C) Enregistrement de périodes de fortes et faibles 
énergies à l'embouchure d'un fleuve. Le cas du Paraiba do Sul (Brésil). Implications paléoclimatiques. Comptes Rendus Hebdomadaires des Seances de L'Academie des Sciences. Ser.II, 299:661-664.

MARTIN, L; SUGUIO, K.; FLEXOR, J.M. (1984d) Informações fornecidas pelos sambaquis na reconstrução de paleolinhas de praia quaternária. Exemplos da costa brasileira. Revieta PréHistória, 6:128-147.

MARTIN, L; SUGUIO, K; FLEXOR, J.M.; DOMINGUEZ, J.M.L; AZEVEDO, A.E.G. (1984e) Evoluçăo da planície costeira do Rio Parafba do Sul (RJ) durante o Quaternário: influência das variaçóes do nível do mar. In: CONGRESSO BRASILEIRO DE GEOLOGIA, 33., Rio de Janeiro, 1984. Anais. Rio de Janeiro, SBG. v.1, p.84-97.

MARTIN, L.; FLEXOR; J.M.; BLTZKOW, D.; SUGUIO, K. (1985a) Geoid change indications along the Brazilian coast during the last 7,000 years. In: INTERNATIONAL CORAL REEF CONGRESS, 5., Tahiti, 1985. Proceedings, Tahiti. v.3, p.85-90.

MARTIN, L; SUGUIO, K.; FLEXOR, J.M.; TESSLER, M;G.; EICHLER, B.B. (1985b) Roundness in Holocene sands of the Paraiba do Sul coastal plain, Rio de Janeiro, Brazil. Journal of Coastal Research, 1(1):343-351.

MARTIN, L; DOMINGUEZ, J.M.L; SUGUIO, K. (1986a) Consequence of relative sea level changes during the Quaternary on sandy coastal sedimentation: examples of Brazil. In: RABASSA, J. (ed.) Quaternary of South America and Antarctic Peninsula. Rotterdam, A.A.Balkema Publishers, v.4, p.119-135.

MARTIN, L; FLEXOR, J.M.; BITTENCOURT, A.C.S.P.; DOMINGUEZ, J.M.L (1986b) Neotectonic movements on a passive continental margin, Salvador region, Brazil. Neotectonic8, 1(1):87-103.

MARTIN, L.; MÖRNER, N.A.; FLEXOR, J.M.; SUGUIO, K. (1986c) Fundamentos e reconstrução de antigos níveis marinhos do Quaternário. Boletim IG/USP. Publicação Especial, (4):1-161.

MARTIN, L.; SUGUIO, K.; FLEXOR, J.M. (1986d) Relative sea level reconstruction during the last 7,000 years along the state of Paraná and Santa Catarina coastal plains: Additional informations derived from shell-middens. In: RABASSA, J. (ed.) Quaternary of South America and Antarctic Peninsula. Rotterdam, A.A.Balkema Publishers. v.4, p.219-236.

MARTIN, L; SUGUIO, K.; FLEXOR, J.M. (1986e) Shell-middens as a source for additional informations in Holocene shoreline and sea level reconstruction: examples from the coast of Brazil. In: VAN DE PLASSCHE, O'. (ed.) Sea level research: a manual for the collection and evaluation of data. Norwich, Geobooks. p.503-521. (A contribution to Projects 61 and 200, IGCP).

MARTIN, L.; SUGUIO, K.; FLEXOR, (1988) Hauts niveaux marins pléistocènes du littoral brésilien. Palaeogeography, Palaeoclimatology, Palaeoecology, 68(2/4):231-239. 
MASSAD, F. (1985) Progressos recentes dos estudos sobre as argilas quaternárias da Babcada

Santista. São Paulo, ABMS/ABEF.

MCKEE, E.D. (1939) Some types of bedding in the Colorado river delta. Journal of Geology, 47:64-81. MOORE, D.C. (1966) Deltaic sedimentation. Earth Science Reviews, 1:87-104.

MORGAN, J.P. (ed.) (1970) Deltaic sedimentation: modern and ancient. Tulsa, S.E.P.M. 312p.

(Society of Economic Paleontologists and Mineralogists, Special Publication, 15).

MÖRNER, N.A. (1980) Eustasy and geiod changes as a function of core/mantle changes. In:

MÖRNER, N.A. (ed.) Earth rheology, isostasy and eustasy. Inglaterra. John Wiley \& Sons. p.535-553.

MÖRNER, N.A. (1984) Interaction and complexity of sea level changes, vertical crustal movements and

geoid deformations. In: SYMPOSIUM ON NEOTECTONICS AND SEA LEVEL VARIATIONS IN GULF OF CALIFORNIA AREA. Hermosillo, 1984. Abstracts. Hermosillo. p.129.

MUNNE, A.l. et al. (1972) Análise estratigráfica do Andar Dom João na Bacia do Recôncavo e Tucano

Sul. Salvador, Petrobrás/SEPES. 77p. (Relatório Técnico, 8).

OFF, J. (1963) Rhythmic linear sand bodies caused by tidal currents. A.A.P.G. Bulletin 47(2):324-341.

OOMKENS, E. (1970) Depositional sequence and sand distribution in a deltaic complex. Geologie in Mijnbouw, 46(7):265-278.

PEDREIRA, A.J.C.L. (1971) Geologia da faixa costeira de Canavieiras e Belmonte. Boletim Técnico. Centro de Pesquisas do Cacau, (13):5-15.

PONTE, F.C. (1969) Estudo morfoestrutural da Bacia Alagoas-Sergipe. Boletim Técnico da Petrobrás, 12(4):439-474.

PONTE, F.C. et al. (1971) Evolução paleogeográfica do Brasil Oriental e África Ocidental. Salvador, Petrobrás/CPEG. 71p. (Relatório Interno, 4).

READING, H.G. (1979) Sedimentary environments and facies. Elsevier, New York. 544p.

RODRIGUES, S.A.; SUGUIO, K.; SHIMIZU, G.Y. (1984) Ecologia e paleoecologia de Callichirus major SAY-1918-Crustacea Decapoda, Thalassinidea. In: SEMINÁRIO REGIONAL DE ECOLOGIA, São Carlos, 1984. Anais. São Carlos. p.499-519.

SCHWARTZ, M.L. (1965) Laboratory study of sea-level rise as a cause of shore erosion. Journal of Geology, 73(3):528-534.

SCHWARTZ, M.L. (1967) The Bruun theory of sea-level rise as a cause of shore erosion. Journal of Geology, 75(1):76-92.

SCOTT, A.J. \& FISHER, W.L (1969) Delta systems and deltaic deposition. Discussion notes. Austin,

Department of Geological Sciences, Bureau of Economic Geology, University of Texas.

SILVEIRA, J.D. (1964) Morfologia do litoral. In: AZEVEDO, A. de (ed.) Brasil, a terra e o homem. 
São Paulo, Companhia Editora Nacional. p.253-305.

SUGUIO, K. (1977) Annotated bibliography (1960-1977) on Quaternary shorelines and sea-level changes in Brazil. Contribution Project 61 IGCP (IUGS/UNESCO). 35p.

SUGUIO, K. \& MARTIN, L. (1976a) Brazilian coastline Quaternary formations. The states of São Paulo and Bahia littoral zone evolutive schemes. Proceedings of the International Symposium on Continental Margins of Atlantic Type, . Anais da Academia Brasileira de Ciências, (Suplemento) 48:325-333.

SUGUIO, K. \& MARTIN, L. (1976b) Presença de tubos fósseis de Callianassa nas formaçöes quaternárias do litoral paulista e sua utilização na reconstrução paleoambiental. Boletim IG-USP, 7:17-26.

SUGUIO, K. \& MARTIN, L (1978a) Quaternary marine formations of the State of São Paulo and southern Rio de Janeiro. In: INTERNATIONAL SYMPOSIUM ON COASTAL EVOLUTION IN THE QUATERNARY. São Paulo, 1978. Special Publication, n¹. São Paulo, Instituto de Geociências, SBG. p.1-55.

SUGUIO, K. \& MARTIN, L. (1978b) Mecanismos de gênese das planícies sedimentares quaternárias do litoral do Estado de São Paulo. In: CONGRESSO BRASILEIRO DE GEOLOGIA, 29., Ouro Preto, 1976. Anais. Ouro Preto, SBG. v.1, p.295-305.

SUGUIO, K. \& MARTIN, L (1978C) Mapas das formações quaternárias do litoral paulista e sul fluminense. São Paulo, Secretaria de Obras e do Meio Ambiente/Departamento de Águas e Energia Elétrica. 8 folhas. Escala 1:100.000.

SUGUIO, K. \& MARTIN, L. (1982a) Progress in research on Quaternary sea-level changes and coastal evolution in Brazil. In: SYMPOSIUM ON HOLOCENE SEA-LEVEL FLUCTUATIONS, MAGNITUDE AND CAUSES. Columbia, 1982. Proceedings. Columbia University of South Carolina. p.166-181

SUGUIO, K. \& MARTIN, L (1982b) Significance of Quaternary sea-level fluctuations for delta construction along the Brazilian coast. Geo-Marine Letters, 1(3/4):181-185.

SUGUIO, K.; MARTIN, L; FLEXOR, J.M. (1980) Sea level fluctuations during the past 6,000 years along the coast of the State of São Paulo. In: MÖRNER, N.A. (ed.) Earth rheology, isostasy and eustasy. Inglaterra, John Wiley \& Sons, p.471-486.

SUGUIO, K.; MARTIN, L; DOMINGUEZ, J.M.L. (1982) Evolução do "delta" do Rio Doce (ES) durante o Quaternário: influência das variações do nível do mar. In: SIMPÓSIO DO QUATERNÁRIO NO BRASIL, 4., Rio de Jäneiro, 1982. Atas. Rio de Janeiro, CTCQ, SBG. p.93-116.

SUGUIO, K.; RODRIGUES, S.A.; TESSLER, M.G.; LAMBOOY, E.E. (1984) Tubos de ophiomorphas e outras feições de bioturbação na Formação Cananéia, Pleistoceno da planície costeira CananéiaIguape. In: LACERDA, LD. (eds.) Restingas: origem, estruturas, processos. Niterói. p.111-122 
SUGUIO, K., BITTENCOURT, A.C.S.P.; DOMINGUEZ, J.M.L; FLEXOR, J.M.; AZEVEDO, A.E.G. (1985a) Flutuações do nivel relativo do mar durante o Quaternário Superior ao longo do litoral brasileiro e suas implicações na sedimentação costeira. Revista Brasileira de Geociências, 15(4):273-286.

SUGUIO, K.; TESSLER, M.G.; EICHLER, B.B.; MARTIN, L; FLEXOR, J.M. (1985b) Depositional mechanisms active during the late Quaternary at the Paraiba do Sul river mouth area, State of Rio de Janeiro, Brazil. In: RABASSA, J. (ed.) Quaternary of South America and Antarctic Peninsula. Rotterdam, A.A.Balkema Publishers, v.3, p.175-185.

SUGUIO, K.; MARTIN, L; FLEXOR, J.M.; AZEVEDO, A.E.G. (1986) The Quaternary sedimentary deposits in the states of Paraná and Santa Catarina coastal plains. In: RABASSA, J. (ed.) Quaternary of South America and Antarctic Peninsula. Rotterdam, A.A.Balkema Publishers, v.4, p.3-25.

SWIFT, D.J.P. (1976) Coastal sedimentation. In: STANLEY, D.J. \& SWIFT, D.J.P. (eds.) Marine sediments transport and environmental management. John Wiley. p.255-310.

THOMPSON, R.W. (1968) Tidal flat sedimentation on the Colorado river delta, northwestern Gulf of California. Geological Society of America Memoir, (107):1-133.

TOMAZEU, L.J.; VILWOCK, J.A.; LOSS, E.L; DEHNHARDT. E.A. (1982) Caracterização de um depósito praial pleistocênico na Província Costeira do Rio Grande do Sul, Brasil. In: CONGRESSO BRASILEIRO DE GEOLOGIA, 32., Salvador, 1982. Anais. Salvador, SBG. v.4, 1514-1523.

TRICART, J. \& CARDOSO DA SILVA, T. (1968) Estudos de geomorfologia da Bahia e Sergipe. Publicação da Fundação para o Desenvolvimento da Ciência na Bahia, 167p.

TROWNBRIDGE, A.C. (1930) Building of Mississippi. American Association Petroleum Geologists Bulletin, 14:867-901.

UNESCO (1971) Discharge of selected rivers of the world. Serie studies and reports in hydrology. (2):92-93.

VAN ANDEL, T.H. (1968) The Orinoco delta. Journal of Sedimentary Petrology, 37(2):297-310.

VAN ANDEL, T.H. \& LABOREL, J. (1964) Recent high sea-level stand near Recife, Brazil. Science, 145(3632):580-581.

VIANA, C.F. (1980) Cronoestratigrafia dos sedimentos da margem continental brasileira. In: CONGRESSO BRASILEIRO DE GEOLOGIA, 31., Camboriú, 1980. Anais. Camboriú, SBG. v.2, p.832-843.

VILAS-BOAS, G.S.; MARTIN, L; BITTENCOURT, A.C.S.P.; FLEXOR, J.M. (1979) Paleoclimatic and paleogeographic evolution during the Quaternary of part of the coast of the State of Bahia between 
Ilhéus and north of Salvador (Brazil). In: INTERNATIONAL SYMPOSIUM ON COASTAL EVOLUTION IN THE QUATERNARY, São Paulo, 1978. Proceedings. São Paulo, Instituto de Geociências/SBG. p.254-263.

VILAS-BOAS, G.S.; BITTENCOURT, A.C.S.P.; MARTIN, L. (1985) Leques aluviais pleistocênicos da região costeira do Estado da Bahia. Revista Brasileira de Geociências, 15(3):255-258.

VIUWOCK, J.A. (1984) Geology of the Coastal Province of Rio Grande do Sul, southern Brazil. A synthesis. Pesquisas, UFRGS, 16:5-49.

VILWOCK, J.A.; TOMAZEU, J.L.; LOSS, E.L; DEHNHARDT, E.A.; HORN FILHO, N.O.; BACHI, F.A.; DEHNHARDT, B.A. (1986) Geology of the Rio Grande do Sul Coastal Province. In: RABASSA, J. (ed.) Quaternary of South America and Antarctic Peninsula. Rotterdam, A.A.Balkema Publishers, v.4, p.79-97.

WRIGHT, LD. (1978) River deltas. In: DAVIS, R.A. (ed.) Coastal sedimentary environments. New York, Springer-Verlag, p.5-68.

WRIGHT, L.D.; COLEMAN, J.M.; ERICKSON, M.V. (1975) Analysis of major river systems and their deltas: morphologic and process comparison. Louisiana State University Coastal Studies Institute, Technical Report (156):1-114p. 


\section{APÊNDICE}

Datações ao radiocarbono de conchas de moluscos ou fragmentos de madeira, amostradas de sedimentos das planícies costeiras. 
Planície Costeira do Rio Doce

\begin{tabular}{|c|c|c|c|c|c|}
\hline № Amostra & Coordenadas & $\begin{array}{l}\text { Natureza } \\
\text { da amostra }\end{array}$ & $\begin{array}{l}\text { Idade }{ }^{14} \mathrm{C} \\
\left.\text { (Corr. } \delta^{13} \mathrm{C}\right)\end{array}$ & Ref.Labo & Ambiente \\
\hline RD.29 & $\begin{array}{l}19^{\circ} 44^{\prime} \mathrm{S} \\
40^{\circ} 02,2^{\prime} \mathrm{W}\end{array}$ & Conchas & $7.150 \pm 200$ & Bah.953 & Lagunar \\
\hline RD.33 & $\begin{array}{l}19^{\circ} 41^{\prime} \mathrm{S} \\
40^{\circ} 01,7^{\prime} \mathrm{W}\end{array}$ & Madeira & $6.900 \pm 250$ & Bah.973 & Lagunar \\
\hline PP009-1 & $\begin{array}{l}19^{\circ} 41,8^{\prime} \mathrm{S} \\
40^{\circ} 02,0^{\prime} \mathrm{W}\end{array}$ & Conchas & $6.350 \pm 200$ & SPC.006 & Lagunar \\
\hline RD.30 & $\begin{array}{l}19^{\circ} 43,2^{\prime} \mathrm{S} \\
40^{\circ} 01,8^{\prime} \mathrm{W}\end{array}$ & Conchas & $6.280 \pm 200$ & Bah.954 & Lagunar \\
\hline RD.31 & $\begin{array}{l}19^{\circ} 42,5^{\prime} \mathrm{S} \\
40^{\circ} 01,8^{\prime} \mathrm{W}\end{array}$ & Conchas & $6.280 \pm 200$ & Bah.955 & Lagunar \\
\hline PB.0152 & $\begin{array}{l}19^{\circ} 41,2^{\prime} \mathrm{S} \\
40^{\circ} 00,9^{\prime} \mathrm{W}\end{array}$ & Conchas & $6.150 \pm 250$ & SPC.010 & Lagunar \\
\hline RD.20 & $\begin{array}{l}19^{\circ} 14^{\prime} \mathrm{S} \\
39^{\circ} 49^{\prime} \mathrm{W}\end{array}$ & Madeira & $6.120 \pm 200$ & Bah.975 & Lagunar \\
\hline PP009-2 & $\begin{array}{l}19^{\circ} 41,8^{\prime} \mathrm{S} \\
40^{\circ} 02,0^{\prime} \mathrm{W}\end{array}$ & Conchas & $6.030 \pm 250$ & SPC.014 & Lagunar \\
\hline RD.21 & $\begin{array}{l}19^{\circ} 14^{\prime} \mathrm{S} \\
39^{\circ} 49^{\prime} \mathrm{W}\end{array}$ & Conchas & $6.020 \pm 200$ & Bah.950 & Lagunar \\
\hline PP009-3 & $\begin{array}{l}19^{\circ} 41,8^{\prime} \mathrm{S} \\
40^{\circ} 02,0^{\prime} \mathrm{W}\end{array}$ & Conchas & $5.880 \pm 230$ & SPC.005 & Lagunar \\
\hline RD.34 & $\begin{array}{l}19^{\circ} 40,7^{\prime} \mathrm{S} \\
40^{\circ} 00,5^{\prime} \mathrm{W}\end{array}$ & Conchas & $5.800 \pm 200$ & Bah.957 & Lagunar \\
\hline RD.05 & $\begin{array}{l}18^{\circ} 57^{\prime} \mathrm{S} \\
39^{\circ} 46,5^{\prime} \mathrm{W}\end{array}$ & Madeira & $5.740 \pm 200$ & Bah.969 & Lagunar \\
\hline PP009-8 & $\begin{array}{l}19^{\circ} 41,8^{\prime} \mathrm{S} \\
40^{\circ} 02,0^{\prime} \mathrm{W}\end{array}$ & Conchas & $5.670 \pm 250$ & SPC.013 & Lagunar \\
\hline RD.32 & $\begin{array}{l}19^{\circ} 41 ' \mathrm{~S} \\
40^{\circ} 07,7^{\prime} \mathrm{W}\end{array}$ & Conchas & $5.600 \pm 200$ & Bah.956 & Lagunar \\
\hline
\end{tabular}




\begin{tabular}{|c|c|c|c|c|c|}
\hline RD.24 & $\begin{array}{l}19^{\circ} 12^{\prime} \mathrm{S} \\
39^{\circ} 49^{\prime} \mathrm{W}\end{array}$ & Conchas & $5.550 \pm 200$ & Bah.952 & Lagunar \\
\hline PP029-1 & $\begin{array}{l}19^{\circ} 42,8^{\prime} \mathrm{S} \\
40^{\circ} 02,1^{\prime} \mathrm{W}\end{array}$ & Conchas & $5.400 \pm 250$ & SPC.039 & Lagunar \\
\hline RD.22 & $\begin{array}{l}19^{\circ} 14^{\prime} \mathrm{S} \\
39^{\circ} 49^{\prime} \mathrm{W}\end{array}$ & Madeira & $5.290 \pm 200$ & Bah.971 & Lagunar \\
\hline RD.13 & $\begin{array}{l}19^{\circ} 28,5^{\prime} \mathrm{S} \\
39^{\circ} 49,9^{\prime} \mathrm{W}\end{array}$ & Madeira & $4.670 \pm 200$ & Bah.966 & Lagunar \\
\hline RD.19 & $\begin{array}{l}19^{\circ} 08,2^{\prime} \mathrm{S} \\
39^{\circ} 43,6^{\prime} \mathrm{W}\end{array}$ & Conchas & $4.630 \pm 200$ & Bah.949 & Praial \\
\hline RD.12 & $\begin{array}{l}19^{\circ} 28,3^{\prime} \mathrm{S} \\
39^{\circ} 49,8^{\prime} W\end{array}$ & Madeira & $4.620 \pm 200$ & Bah.965 & Lagunar \\
\hline RD.14 & $\begin{array}{l}19^{\circ} 31^{\prime} \mathrm{S} \\
39^{\circ} 49^{\prime} \mathrm{W}\end{array}$ & Madeira & $4.600 \pm 200$ & Bah.967 & Lagunar \\
\hline PP.358 & $\begin{array}{l}19^{\circ} 12,8^{\prime} \mathrm{S} \\
39^{\circ} 48,8^{\prime} \mathrm{W}\end{array}$ & Conchas & $4.400 \pm 200$ & SPC. 027 & Sambaqui \\
\hline RD.16 & $\begin{array}{l}19^{\circ} 17^{\prime} \mathrm{S} \\
39^{\circ} 49^{\prime} \mathrm{W}\end{array}$ & Madeira & $4.250 \pm 200$ & Bah.960 & Lagunar \\
\hline PMX & $\begin{array}{l}18^{\circ} 52,0^{\prime} \mathrm{S} \\
39^{\circ} 48,2^{\prime} \mathrm{W}\end{array}$ & Conchas & $4.240 \pm 150$ & SPC.034 & Sambaqui \\
\hline RD.06 & $\begin{array}{l}18^{\circ} 57^{\prime} \mathrm{S} \\
39^{\circ} 46^{\prime} \mathrm{W}\end{array}$ & Conchas & $4.000 \pm 150$ & Bah.943 & Praial \\
\hline RD.09 & $\begin{array}{l}18^{\circ} 58^{\prime} \mathrm{S} \\
39^{\circ} 48^{\prime} \mathrm{W}\end{array}$ & Conchas & $3.950 \pm 150$ & Bah.945 & Lagunar \\
\hline RD.11 & $\begin{array}{l}19^{\circ} 32,2^{\prime} \mathrm{S} \\
39^{\circ} 48,2^{\prime} \mathrm{W}\end{array}$ & Madeira & $3.940 \pm 150$ & Bah.964 & Praial \\
\hline RD.23 & $\begin{array}{l}19^{\circ} 09,0 \mathrm{~S} \\
39^{\circ} 50,3^{\prime} \mathrm{W}\end{array}$ & Conchas & $3.550 \pm 200$ & Bah.951 & Sambaqui \\
\hline RD.01 & $\begin{array}{l}18^{\circ} 57,0^{\prime} S \\
39^{\circ} 46,3 W\end{array}$ & Conchas & $3.540 \pm 150$ & Bah.942 & Lagunar \\
\hline RD.18 & $\begin{array}{l}19^{\circ} 08,2^{\prime} \mathrm{S} \\
39^{\circ} 43,6^{\prime} \mathrm{W}\end{array}$ & Conchas & $3.520 \pm 150$ & Bah.948 & Praial \\
\hline RD.28 & $\begin{array}{l}19^{\circ} 37^{\prime} \mathrm{S} \\
39^{\circ} 55^{\prime} \mathrm{W}\end{array}$ & Madeira & $3.430 \pm 150$ & Bah.962 & Lagunar \\
\hline
\end{tabular}




\begin{tabular}{|c|c|c|c|c|c|}
\hline RD.10 & $\begin{array}{l}19^{\circ} 02,5^{\prime} \mathrm{S} \\
39^{\circ} 47, \mathrm{O}^{\prime} \mathrm{W}\end{array}$ & Conchas & $3.300 \pm 200$ & Bah.946 & Lagunar \\
\hline RD.17 & $\begin{array}{l}19^{\circ} 08,2^{\prime} \mathrm{S} \\
49^{\circ} 43,6^{\prime} \mathrm{W}\end{array}$ & Conchas & $3.140 \pm 150$ & Bah.947 & Praial \\
\hline RD.04 & $\begin{array}{l}18^{\circ} 56,5^{\prime} \mathrm{S} \\
39^{\circ} 44,5^{\prime} \mathrm{W}\end{array}$ & Conchas & $3.070 \pm 150$ & Bah.958 & Praial \\
\hline RD.07 & $\begin{array}{l}18^{\circ} 57,5^{\prime} \mathrm{S} \\
39^{\circ} 47, \mathrm{O}^{\prime} \mathrm{W}\end{array}$ & Conchas & $3.060 \pm 150$ & Bah.944 & Lagunar \\
\hline PP.347 & $\begin{array}{l}18^{\circ} 52,0^{\prime} \mathrm{S} \\
39^{\circ} 48^{\prime} \mathrm{W}\end{array}$ & Conchas & $2.970 \pm 180$ & SPC.035 & Sambaqui \\
\hline RD. 08 & $\begin{array}{l}18^{\circ} 57,5^{\prime} \mathrm{S} \\
39^{\circ} 47,7^{\prime} \mathrm{W}\end{array}$ & Madeira & $2.840 \pm 150$ & Bah.970 & Lagunar \\
\hline
\end{tabular}

Planície Costeira do Rio Paraiba do Sul

\begin{tabular}{|c|c|c|c|c|c|}
\hline PS.05 & $\begin{array}{l}22^{\circ} 04,4^{\prime S} \\
41^{\circ} 08,3^{\prime} \mathrm{W}\end{array}$ & Conchas & $7.390 \pm 270$ & Bah.1119 & Lagunar \\
\hline PS.06 & $\begin{array}{l}22^{\circ} 04^{\prime} \mathrm{S} \\
41^{\circ} 09^{\prime} \mathrm{W}\end{array}$ & Conchas & $7.060 \pm 260$ & Bah.1120 & Lagunar \\
\hline SD.10A & $\begin{array}{l}21^{\circ} 55,2^{\prime} S \\
41^{\circ} 27,3^{\prime} W\end{array}$ & Conchas & $7.010 \pm 250$ & Bah.1005 & Lagunar \\
\hline PS.52 & $\begin{array}{l}22^{\circ} 06,7^{\prime} S \\
41^{\circ} 20,7^{\prime} W\end{array}$ & Conchas & $6.920 \pm 280$ & Bah.1257 & Lagunar \\
\hline SD.03 & $\begin{array}{l}22^{\circ} 04,4^{\prime} \mathrm{S} \\
41^{\circ} 09,5^{\prime} \mathrm{W}\end{array}$ & Conchas & $6.860 \pm 200$ & Bah.995 & Lagunar \\
\hline SD.11 & $\begin{array}{l}21^{\circ} 56,0^{\prime} S \\
41^{\circ} 25,3^{\prime} W\end{array}$ & Madeira & $6.830 \pm 200$ & Bah.1007 & Lagunar \\
\hline PS.07 & $\begin{array}{l}22^{\circ} 04,4^{\prime} \mathrm{S} \\
41^{\circ} 09,5^{\prime} \mathrm{W}\end{array}$ & Conchas & $6.730 \pm 260$ & Bah.1121 & Lagunar \\
\hline PS.14 & $\begin{array}{l}22^{\circ} 12,5^{\prime} \mathrm{S} \\
41^{\circ} 28,7^{\prime} \mathrm{W}\end{array}$ & Conchas & $6.620 \pm 230$ & Bah.1107 & Lagunar \\
\hline
\end{tabular}




\begin{tabular}{|c|c|c|c|c|c|}
\hline PS.12 & $\begin{array}{l}22^{\circ} 06,8^{\prime} \mathrm{S} \\
41^{\circ} 10,3^{\prime} W\end{array}$ & Madeira & $6.590 \pm 250$ & Bah.1105 & Lagunar \\
\hline SD.09B & $\begin{array}{l}21^{\circ} 57,8^{\prime} S \\
41^{\circ} 12^{\prime} \mathrm{W}\end{array}$ & Madeira & $6.590 \pm 200$ & Bah.1004 & Lagunar \\
\hline PS.26 & $\begin{array}{l}21^{\circ} 52,5^{\prime} \mathrm{S} \\
41^{\circ} 23,1^{\prime} \mathrm{W}\end{array}$ & Madeira & $6.570 \pm 260$ & Bah.1133 & Lagunar \\
\hline PS.22 & $\begin{array}{l}21^{\circ} 57,0^{\prime} \mathrm{S} \\
41^{\circ} 27,5^{\prime} \mathrm{W}\end{array}$ & Madeira & $6.570 \pm 260$ & Bah.1135 & Lagunar \\
\hline PS.09 & $\begin{array}{l}22^{\circ} 03,8^{\prime} \mathrm{S} \\
41^{\circ} 10,5^{\prime} \mathrm{W}\end{array}$ & Madeira & $6.470 \pm 240$ & Bah.1123 & Lagunar \\
\hline PS.04 & $\begin{array}{l}22^{\circ} 03,9^{\prime} \mathrm{S} \\
41^{\circ} 08,3^{\prime} \mathrm{W}\end{array}$ & Conchas & $6.160 \pm 240$ & Bah.1118 & Lagunar \\
\hline PS.43 & $\begin{array}{l}21^{\circ} 32,5^{\prime} \mathrm{S} \\
41^{\circ} 08,5^{\prime} \mathrm{W}\end{array}$ & Conchas & $6.100 \pm 200$ & Bah.1095 & Lagunar \\
\hline PS.08 & $\begin{array}{l}22^{\circ} 03,0^{\prime} \mathrm{S} \\
41^{\circ} 12,2^{\prime} \mathrm{W}\end{array}$ & Conchas & $6.060 \pm 240$ & Bah.1122 & Lagunar \\
\hline PS.41 & $\begin{array}{l}22^{\circ} 12,5^{\prime} \mathrm{S} \\
41^{\circ} 28,7^{\prime} \mathrm{W}\end{array}$ & Conchas & $6.000 \pm 230$ & Bah.1108 & Lagunar \\
\hline SD.09-A & $\begin{array}{l}21^{\circ} 57,8^{\prime} \mathrm{S} \\
41^{\circ} 12,2^{\prime} \mathrm{W}\end{array}$ & Conchas & $6.000 \pm 200$ & Bah.1003 & Lagunar \\
\hline SD.10-B & $\begin{array}{l}21^{\circ} 55,2^{\prime} \mathrm{S} \\
41^{\circ} 27,3^{\prime} \mathrm{W}\end{array}$ & Madeira & $6.000 \pm 200$ & Bah.1006 & Lagunar \\
\hline PS.110 & $\begin{array}{l}21^{\circ} 55,2^{\prime} \mathrm{S} \\
41^{\circ} 27,3^{\prime} \mathrm{W}\end{array}$ & Conchas & $5.970 \pm 200$ & Bah.1263 & Lagunar \\
\hline A.22-2 & $\begin{array}{l}22^{\circ} 05,4^{\prime} \mathrm{S} \\
41^{\circ} 08,8^{\prime} \mathrm{W}\end{array}$ & Conchas & $5.940 \pm 240$ & Bah.1565 & Lagunar \\
\hline PS.13 & $\begin{array}{l}22^{\circ} 06,8^{\prime} \mathrm{S} \\
41^{\circ} 10,3^{\prime} \mathrm{W}\end{array}$ & Conchas & $5.930 \pm 240$ & Bah.1106 & Lagunar \\
\hline A.22-3 & $\begin{array}{l}22^{\circ} 05,4^{\prime} \mathrm{S} \\
41^{\circ} 08,8^{\prime} \mathrm{W}\end{array}$ & Conchas & $5.790 \pm 230$ & Bah.1566 & Lagunar \\
\hline PS.03 & $\begin{array}{l}22^{\circ} 04,0^{\prime} \mathrm{S} \\
41^{\circ} 06,3^{\prime} \mathrm{W}\end{array}$ & Conchas & $5.560 \pm 230$ & Bah.1117 & Lagunar \\
\hline A.20-1 & $\begin{array}{l}22^{\circ} 04,0^{\prime} S \\
41^{\circ} 06,3^{\prime} W\end{array}$ & Conchas & $5.560 \pm 220$ & Bah.1562 & Lagunar \\
\hline
\end{tabular}




\begin{tabular}{|c|c|c|c|c|c|}
\hline PS.25 & $\begin{array}{l}21^{\circ} 57,2^{\prime} \mathrm{S} \\
41^{\circ} 18,7^{\prime} \mathrm{W}\end{array}$ & Madeira & $5.460 \pm 280$ & Bah.1132 & Lagunar \\
\hline PS.135 & $\begin{array}{l}21^{\circ} 22,2^{\prime} S \\
40^{\circ} 58,3^{\prime} W\end{array}$ & Conchas & $5.460 \pm 220$ & Bah.1265 & Lagunar \\
\hline A. $15-1$ & $\begin{array}{l}22^{\circ} 09,7^{\prime} \mathrm{S} \\
42^{\circ} 18,0^{\prime} \mathrm{W}\end{array}$ & Conchas & $5.430 \pm 220$ & Bah.1520 & Lagunar \\
\hline PS.19 & $\begin{array}{l}21^{\circ} 58,6^{\prime} \mathrm{S} \\
41^{\circ} 01,3^{\prime} \mathrm{W}\end{array}$ & Conchas & $5.410 \pm 230$ & Bah.1109 & Lagunar \\
\hline A.18-1 & $\begin{array}{l}22^{\circ} 03,8^{\prime} \mathrm{S} \\
41^{\circ} 25,1^{\prime} \mathrm{W}\end{array}$ & Madeira & $5.340 \pm 230$ & Bah.1561 & Lagunar \\
\hline A.125 & $\begin{array}{l}21^{\circ} 35,5^{\prime} \mathrm{S} \\
41^{\circ} 11,6^{\prime} \mathrm{W}\end{array}$ & Madeira & $5.270 \pm 220$ & Bah.1264 & Lagunar \\
\hline SD.04-A & $\begin{array}{l}22^{\circ} 02,3^{\prime} S \\
41^{\circ} 06,0^{\prime} W\end{array}$ & Conchas & $5.140 \pm 200$ & Bah.996 & Lagunar \\
\hline A.22-1 & $\begin{array}{l}22^{\circ} 05,4^{\prime} \mathrm{S} \\
41^{\circ} 08,8^{\prime} \mathrm{W}\end{array}$ & Conchas & $4.970 \pm 220$ & Bah.1564 & Lagunar \\
\hline SD.02 & $\begin{array}{l}22^{\circ} 06,8^{\prime} \mathrm{S} \\
41^{\circ} 28,7^{\prime} \mathrm{W}\end{array}$ & Conchas & $4.970 \pm 200$ & Bah.994 & Lagunar \\
\hline A. $21-1$ & $\begin{array}{l}22^{\circ} 04,4^{\prime} S \\
41^{\circ} 08,3^{\prime} W\end{array}$ & Conchas & $4.960 \pm 220$ & Bah.1563 & Lagunar \\
\hline PS.42 & $\begin{array}{l}21^{\circ} 33,1^{\prime} \mathrm{S} \\
41^{\circ} 08,8^{\prime} \mathrm{W}\end{array}$ & Conchas & $4.390 \pm 200$ & Bah.1094 & Praial \\
\hline PS.41 & $\begin{array}{l}21^{\circ} 33,1^{\prime} \mathrm{S} \\
41^{\circ} 09,2^{\prime} \mathrm{W}\end{array}$ & Conchas & $4.380 \pm 200$ & Bah.1093 & Praial \\
\hline PS.40 & $\begin{array}{l}21^{\circ} 33,1^{\prime} \mathrm{S} \\
41^{\circ} 28,7^{\prime} \mathrm{W}\end{array}$ & Conchas & $4.160 \pm 210$ & Bah.1096 & Praial \\
\hline PS.35 & $\begin{array}{l}21^{\circ} 28,4^{\prime} S \\
41^{\circ} 04,1^{\prime} W\end{array}$ & Conchas & $3.850 \pm 200$ & Bah.1102 & Praial \\
\hline PS.87 & $\begin{array}{l}21^{\circ} 55,8^{\prime} \mathrm{S} \\
41^{\circ} 03,5^{\prime} \mathrm{W}\end{array}$ & Conchas & $3.780 \pm 170$ & Bah.1280 & Lagunar \\
\hline PS.89-2 & $\begin{array}{l}21^{\circ} 31,7^{\prime} \mathrm{S} \\
41^{\circ} 07,3^{\prime} \mathrm{W}\end{array}$ & Madeira & $3.720 \pm 180$ & Bah.1316 & Praial \\
\hline SD.12 & $\begin{array}{l}21^{\circ} 21,6^{\prime} S \\
39^{\circ} 57,6^{\prime} \mathrm{W}\end{array}$ & Vermetideo & $3.620 \pm 150$ & Bah.1008 & Marinho \\
\hline
\end{tabular}




\begin{tabular}{|c|c|c|c|c|c|}
\hline PS.29 & $\begin{array}{l}21^{\circ} 31,7^{\prime} S \\
41^{\circ} 06,9^{\prime} W\end{array}$ & Conchas & $3.520 \pm 200$ & Bah.1096 & Praial \\
\hline SD.04-C & $\begin{array}{l}22^{\circ} 02,3^{\prime} \mathrm{S} \\
41^{\circ} 06,0^{\prime} \mathrm{W}\end{array}$ & Conchas & $3.380 \pm 140$ & Bah.998 & Lagunar \\
\hline PS.15-B & $\begin{array}{l}21^{\circ} 56,1^{\prime} S \\
41^{\circ} 00,2^{\prime} W\end{array}$ & Conchas & $3.180 \pm 180$ & Bah.1112 & Lagunar \\
\hline PS.15-A & $\begin{array}{l}21^{\circ} 56,1^{\prime} \mathrm{S} \\
41^{\circ} 00,2^{\prime} \mathrm{W}\end{array}$ & Conchas & $3.120 \pm 180$ & Bah.1111 & Lagunar \\
\hline SD.08 & $\begin{array}{l}21^{\circ} 55,0^{\prime} S \\
41^{\circ} 00,3^{\prime} W\end{array}$ & Conchas & $3.060 \pm 150$ & Bah.1002 & Lagunar \\
\hline PS.39 & $\begin{array}{l}21^{\circ} 23,6^{\prime} \mathrm{S} \\
39^{\circ} 59,0^{\prime} \mathrm{W}\end{array}$ & Vermetideo & $3.060 \pm 150$ & Bah.1120 & Marinho \\
\hline SD.06 & $\begin{array}{l}21^{\circ} 56,7^{\prime} S \\
41^{\circ} 00,2^{\prime} W\end{array}$ & Conchas & $3.000 \pm 150$ & Bah.1001 & Lagunar \\
\hline SD.07 & $\begin{array}{l}21^{\circ} 57,1^{\prime} \mathrm{S} \\
41^{\circ} 00,6^{\prime} \mathrm{W}\end{array}$ & Conchas & $3.000 \pm 150$ & Bah.1000 & Lagunar \\
\hline PS.10 & $\begin{array}{l}22^{\circ} 02,0^{\prime} \mathrm{S} \\
41^{\circ} 03,2^{\prime} \mathrm{W}\end{array}$ & Conchas & $3.000 \pm 170$ & Bah.1124 & Lagunar \\
\hline PS.16 & $\begin{array}{l}21^{\circ} 55,0^{\prime} \mathrm{S} \\
41^{\circ} 00,3^{\prime} \mathrm{W}\end{array}$ & Conchas & $2.930 \pm 150$ & Bah.1114 & Lagunar \\
\hline SD.05 & $\begin{array}{l}21^{\circ} 56,1^{\prime} \mathrm{S} \\
41^{\circ} 00,2^{\prime} \mathrm{W}\end{array}$ & Conchas & $2.920 \pm 150$ & Bah.999 & Lagunar \\
\hline PS.11 & $\begin{array}{l}22^{\circ} 02,0^{\prime} \mathrm{S} \\
41^{\circ} 03,2^{\prime} \mathrm{W}\end{array}$ & Conchas & $2.660 \pm 170$ & Bah.1125 & Lagunar \\
\hline PS.31 & $\begin{array}{l}21^{\circ} 31,6^{\prime} \mathrm{S} \\
41^{\circ} 06,6^{\prime} \mathrm{W}\end{array}$ & Conchas & $2.530 \pm 170$ & Bah.1098 & Lagunar \\
\hline PS.89-1 & $\begin{array}{l}21^{\circ} 31,7^{\prime} \mathrm{S} \\
41^{\circ} 07,3^{\prime} W\end{array}$ & Conchas & $2.490 \pm 170$ & Bah.1261 & Lagunar \\
\hline PS.30 & $\begin{array}{l}21^{\circ} 31,7^{\prime} \mathrm{S} \\
41^{\circ} 07,3^{\prime} \mathrm{W}\end{array}$ & Conchas & $2.360 \pm 200$ & Bah.1097 & Lagunar \\
\hline PS.15-C & $\begin{array}{l}21^{\circ} 56,1^{\prime} \mathrm{S} \\
41^{\circ} 00,2^{\prime} \mathrm{W}\end{array}$ & Estromatólito & $2.130 \pm 180$ & Bah.1113 & Hipersalino \\
\hline PS.33 & $\begin{array}{l}21^{\circ} 28,8^{\prime} S \\
41^{\circ} 04,4^{\prime} W\end{array}$ & Conchas & $2.110 \pm 200$ & Bah.1100 & Praial \\
\hline
\end{tabular}


PS.32

PS.34 $21^{\circ} 30,0^{\prime} \mathrm{S}$

$41^{\circ} 05,6^{\prime} \mathrm{W}$

$21^{\circ} 29,0^{\prime} S$

$41^{\circ} 03,8^{\prime} \mathrm{W}$
Conchas

Conchas

$1.070 \pm 160$

Bah.1101

Praial
Planície Costeira do Rio Jequitinhonha

W.15

$$
-5( \pm 1) m
$$

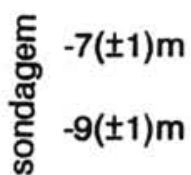$$
-11( \pm 1) m
$$

W.14

$$
-2( \pm 1) m
$$

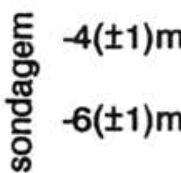$$
-8( \pm 1) m
$$

W.8

$\begin{array}{ll}-4( \pm 1) \mathrm{m} & 15^{\circ} 36,5^{\prime} \mathrm{S} \\ -6( \pm 1) \mathrm{m} & \end{array}$

W.3

$-2( \pm 2) m$

B.335

$15^{\circ} 35,7^{\prime} \mathrm{S}$

$38^{\circ} 58,7^{\prime} \mathrm{W}$

Conchas

$7.330 \pm 200$

$15^{\circ} 50,5^{\prime} \mathrm{S}$

Madeira

$6.180 \pm 140$ $15^{\circ} 33,9^{\prime} \mathrm{S}$

$38^{\circ} 57,9^{\prime} \mathrm{W}$

Conchas

Conchas

Conchas

Conchas

$15^{\circ} 34,5^{\prime} \mathrm{S}$

$38^{\circ} 58,4^{\prime} \mathrm{W}$

Conchas

$6.560 \pm 160$

Bah.900

Conchas

$7.000 \pm 200$

Bah.901

Conchas

$7.320 \pm 200$

Bah.902

Conchas

$7.810 \pm 200$

Bah.903

Lagunar

Lagunar

Lagunar
Lagunar

Lagunar

Lagunar

Bah.879

Lagunar

Bah.814

Lagunar 


\begin{tabular}{|c|c|c|c|c|c|}
\hline B. 438 & $\begin{array}{l}15^{\circ} 50,3^{\prime} \mathrm{S} \\
38^{\circ} 57,5^{\prime} \mathrm{W}\end{array}$ & Madeira & $5.850 \pm 150$ & Bah.910 & Lagunar \\
\hline B.447 & $\begin{array}{l}15^{\circ} 41,5^{\prime} \mathrm{S} \\
39^{\circ} 01,0^{\prime} \mathrm{W}\end{array}$ & Madeira & $5.570 \pm 150$ & Bah.915 & Lagunar \\
\hline B.366 & $\begin{array}{l}15^{\circ} 39,9^{\prime} \mathrm{S} \\
39^{\circ} 03,1^{\prime} \mathrm{W}\end{array}$ & Madeira & $5.300 \pm 140$ & Bah.822 & Lagunar \\
\hline B.370 & $\begin{array}{l}15^{\circ} 36,2^{\prime} \mathrm{S} \\
39^{\circ} 09,8^{\prime} \mathrm{W}\end{array}$ & Madeira & $2.730 \pm 120$ & Bah.823 & Lagunar \\
\hline B. 432 & $\begin{array}{l}15^{\circ} 52,2^{\prime} \mathrm{S} \\
38^{\circ} 54,5^{\prime} \mathrm{W}\end{array}$ & Madeira & $2.570 \pm 100$ & Bah.907 & Lagunar \\
\hline B. 443 & $\begin{array}{l}15^{\circ} 48,5^{\prime} \mathrm{S} \\
39^{\circ} 00,0^{\prime} \mathrm{W}\end{array}$ & Madeira & $2.290 \pm 150$ & Bah.913 & Fluvial \\
\hline B.325 & $\begin{array}{l}15^{\circ} 52,2^{\prime} \mathrm{S} \\
38^{\circ} 54,5^{\prime} \mathrm{W}\end{array}$ & $\begin{array}{l}\text { Detritos } \\
\text { Vegetais }\end{array}$ & $2.240 \pm 100$ & Bah.811 & Praial \\
\hline B. 330 & $\begin{array}{l}15^{\circ} 50,3^{\prime} \mathrm{S} \\
38^{\circ} 57,5^{\prime} \mathrm{W}\end{array}$ & Madeira & $2.020 \pm 120$ & Bah.813 & Fluvial \\
\hline B.351 & $\begin{array}{l}15^{\circ} 43,5^{\prime} \mathrm{S} \\
38^{\circ} 55,0^{\prime} \mathrm{W}\end{array}$ & $\begin{array}{l}\text { Detritos } \\
\text { Vegetais }\end{array}$ & $1.970 \pm 120$ & Bah.819 & Praial \\
\hline B.345 & $\begin{array}{l}15^{\circ} 49,0^{\prime} \mathrm{S} \\
38^{\circ} 53,7^{\prime} \mathrm{W}\end{array}$ & $\begin{array}{l}\text { Detritos } \\
\text { Vegetais }\end{array}$ & $1.800 \pm 100$ & Bah.817 & Praial \\
\hline B.353 & $\begin{array}{l}15^{\circ} 42,3^{\prime} \mathrm{S} \\
38^{\circ} 56,0^{\prime} \mathrm{W}\end{array}$ & $\begin{array}{l}\text { Detritos } \\
\text { Vegetais }\end{array}$ & $1.770 \pm 100$ & Bah.820 & Praial \\
\hline В.327 & $\begin{array}{l}15^{\circ} 50,7^{\prime} \mathrm{S} \\
38^{\circ} 54,5^{\prime} \mathrm{W}\end{array}$ & Madeira & $1.700 \pm 100$ & Bah.812 & Fluvial \\
\hline B.441 & $\begin{array}{l}15^{\circ} 50,0^{\prime} \mathrm{S} \\
38^{\circ} 58,8^{\prime} \mathrm{W}\end{array}$ & Madeira & $1.420 \pm 100$ & Bah.911 & Fluvial \\
\hline B.436 & $\begin{array}{l}15^{\circ} 50,3^{\prime} \mathrm{S} \\
38^{\circ} 57,5^{\prime} \mathrm{W}\end{array}$ & Madeira & $1.400 \pm 100$ & Bah.909 & Fluvial \\
\hline B.339 & $\begin{array}{l}15^{\circ} 47,3^{\prime} \mathrm{S} \\
38^{\circ} 59,7^{\prime} \mathrm{W}\end{array}$ & Madeira & $1.350 \pm 100$ & Bah.816 & Fluvial \\
\hline B.359 & $\begin{array}{l}15^{\circ} 41,4^{\prime} \mathrm{S} \\
38^{\circ} 58,5^{\prime} \mathrm{W}\end{array}$ & Madeira & $1.350 \pm 100$ & Bah.821 & Fluvial \\
\hline B.433 & $\begin{array}{l}15^{\circ} 50,7^{\prime} \mathrm{S} \\
38^{\circ} 55,5^{\prime} \mathrm{W}\end{array}$ & Madeira & $1.070 \pm 100$ & Bah.908 & Fluvial \\
\hline
\end{tabular}




\begin{tabular}{|c|c|c|c|c|c|}
\hline B. 442 & $\begin{array}{l}15^{\circ} 48,5^{\prime} \mathrm{S} \\
38^{\circ} 59,0^{\prime} \mathrm{W}\end{array}$ & Madeira & $1.040 \pm 100$ & Bah.912 & Fluvial \\
\hline B. 445 & $\begin{array}{l}15^{\circ} 48,5^{\prime} \mathrm{S} \\
39^{\circ} 04,5^{\prime} \mathrm{W}\end{array}$ & $\begin{array}{l}\text { Detritos } \\
\text { Vegetais }\end{array}$ & $790 \pm 100$ & Bah.916 & Fluvial \\
\hline B.429 & $\begin{array}{l}15^{\circ} 52,2^{\prime} \mathrm{S} \\
38^{\circ} 54,5^{\prime} \mathrm{W}\end{array}$ & Madeira & $610 \pm 100$ & Bah.905 & Fluvial \\
\hline B. 431 & $\begin{array}{l}15^{\circ} 52,2^{\prime} \mathrm{S} \\
38^{\circ} 54,5^{\prime} \mathrm{W}\end{array}$ & Madeira & $528 \pm 100$ & Bah.906 & Fluvial \\
\hline B.336 & $\begin{array}{l}15^{\circ} 50,5^{\prime} \mathrm{S} \\
38^{\circ} 58,5^{\prime} \mathrm{W}\end{array}$ & Madeira & $520 \pm 100$ & Bah.815 & Fluvial \\
\hline B.444 & $\begin{array}{l}15^{\circ} 48,5^{\prime} \mathrm{S} \\
39^{\circ} 00,0^{\prime} \mathrm{W}\end{array}$ & Madeira & $400 \pm 50$ & Bah.914 & Fluvial \\
\hline B.428 & $\begin{array}{l}15^{\circ} 52,2^{\prime} \mathrm{S} \\
38^{\circ} 54,5^{\prime} \mathrm{W}\end{array}$ & Madeira & $190 \pm 50$ & Bah.904 & Fluvial \\
\hline B.350 & $\begin{array}{l}15^{\circ} 43,5^{\prime} \mathrm{S} \\
38^{\circ} 55,0^{\prime} \mathrm{W}\end{array}$ & Madeira & $130 \pm 100$ & Bah.818 & Fluvial \\
\hline
\end{tabular}

Planície Costeira do Rio São Francisco

\begin{tabular}{|c|c|c|c|c|c|}
\hline SF.07 & $\begin{array}{l}10^{\circ} 20,3^{\prime} S \\
36^{\circ} 28,3^{\prime} W\end{array}$ & Madeira & $5.730 \pm 200$ & Bah.985 & Lagunar \\
\hline SF.19 & $\begin{array}{l}10^{\circ} 25,0^{\prime} \mathrm{S} \\
36^{\circ} 34,0^{\prime} \mathrm{W}\end{array}$ & Madeira & $5.420 \pm 200$ & Bah.987 & Lagunar \\
\hline SF.23 & $\begin{array}{l}10^{\circ} 25,8^{\prime} \mathrm{S} \\
36^{\circ} 31,0^{\prime} \mathrm{W}\end{array}$ & Madeira & $4.680 \pm 210$ & Bah.989 & Mangue \\
\hline SF.09 & $\begin{array}{l}10^{\circ} 21,0^{\prime} \mathrm{S} \\
36^{\circ} 17,8^{\prime} \mathrm{W}\end{array}$ & Coral & $4.310 \pm 150$ & Bah.992 & Marinho \\
\hline SF.21 & $\begin{array}{l}10^{\circ} 25,8^{\prime} S \\
36^{\circ} 31,0^{\prime} \mathrm{W}\end{array}$ & Madeira & $3.380 \pm 150$ & Bah.988 & Fluvial \\
\hline SF.24 & $\begin{array}{l}10^{\circ} 25,9^{\prime} \mathrm{S} \\
36^{\circ} 31,9^{\prime} \mathrm{W}\end{array}$ & Madeira & $290 \pm 150$ & Bah.990 & Fluvial \\
\hline
\end{tabular}


Planície Costeira de Caravelas

B.246

$17^{\circ} 41,4^{\prime} \mathrm{S}$

$39^{\circ} 14,8^{\prime} \mathrm{W}$

B.255

$17^{\circ} 41,0^{\prime} \mathrm{S}$

$39^{\circ} 18,2^{\prime} \mathrm{W}$

B.254

$17^{\circ} 41,0^{\prime} \mathrm{S}$

$39^{\circ} 18,2^{\prime} \mathrm{W}$

B.263

$17^{\circ} 50,5^{\prime} \mathrm{S}$

$39^{\circ} 19,2^{\prime} \mathrm{W}$

B.262

$17^{\circ} 50,5^{\prime} \mathrm{S}$

$39^{\circ} 19,2^{\prime} \mathrm{W}$

B.242

$17^{\circ} 45,0^{\prime} S$ $39^{\circ} 15,8^{\prime} \mathrm{W}$

B.258

$17^{\circ} 49,5^{\prime} \mathrm{S}$

$39^{\circ} 20,2^{\prime} \mathrm{W}$

B.227

$16^{\circ} 19,0^{\prime} S$

$39^{\circ} 00,0^{\prime} \mathrm{W}$

B.261

$17^{\circ} 50,5^{\prime} \mathrm{S}$

$39^{\circ} 19,2^{\prime} \mathrm{W}$

B.307

$17^{\circ} 58,1^{\prime} \mathrm{S}$

$39^{\circ} 12,4^{\prime} \mathrm{W}$

B.260

$17^{\circ} 50,5^{\prime} \mathrm{S}$

$39^{\circ} 19,2^{\prime} \mathrm{W}$

B.316

$17^{\circ} 54,6^{\prime} \mathrm{S}$

$39^{\circ} 20,4^{\prime} \mathrm{W}$

B.265

$17^{\circ} 51,7$ 'S

$39^{\circ} 21,2^{\prime} \mathrm{W}$

B.317

$17^{\circ} 53,5^{\prime} \mathrm{S}$

$39^{\circ} 20,3^{\prime} \mathrm{W}$

Conchas

Conchas

Conchas

Conchas

Conchas

Conchas

Conchas

Coral

Conchas

Conchas

Coral

Coral

Conchas

Conchas

Madeira

Conchas
Bah.765

Bah.768

Bah.767

$6.650 \pm 120$

$5.890 \pm 110$

Bah.773

$5.760 \pm 160$

Bah.772

$5.710 \pm 100$

Bah.762

$5.700 \pm 100$

$5.400 \pm 726$

Bah.726

$4.910 \pm 110$

Bah.771

$4.600 \pm 100$

Bah.802

$4.520 \pm 100$

Bah. 770

$3.670 \pm 100 \quad$ Bah.808

$3.640 \pm 110$

Bah.775

Lagunar

$3.310 \pm 110$

Bah.809

Litorâneo 